Supporting Information for:

\title{
Total Synthesis of (+)-Rubellin C
}

\author{
Jackson A. Gartman and Uttam K. Tambar* \\ Department of Biochemistry, The University of Texas Southwestern Medical Center at Dallas, \\ 5323 Harry Hines Boulevard, Dallas, Texas 75390-9038, United States \\ E-mail: uttam.tambar@utsouthwestern.edu
}

\section{Table of Contents}

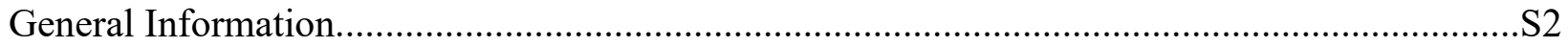

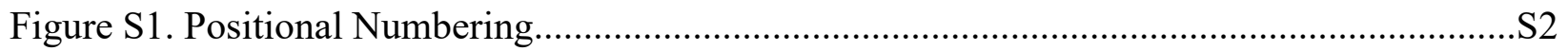

Synthetic Procedures for Known Central Enone Component 8..............................................S3

Synthetic Procedures for Benzyl Grignard Fragment 9................................................... 5

Synthetic Procedures for Known Phthalaldehyde 5 ............................................................. 6

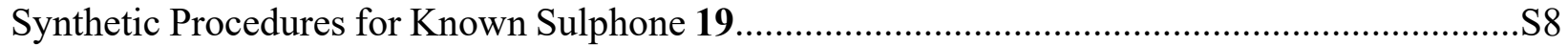

Synthetic Procedures for Allyl Alcohol 11 .........................................................................S10

Synthetic Procedures for Rubellin Core System 15 ............................................................. 12

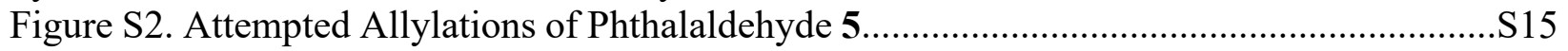

Table S1. Optimization of Allylboronic Acid Formation.......................................................S19

Synthetic Procedures for (+)-Rubellin C (1) from Allylic Alcohol 11....................................S20

Table S2. Optimization of Hauser Annulation.................................................................S22

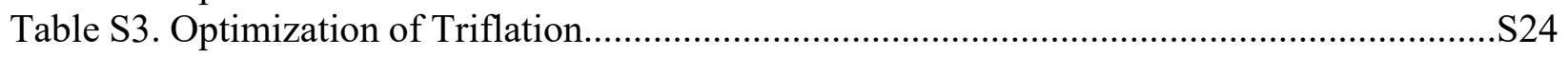

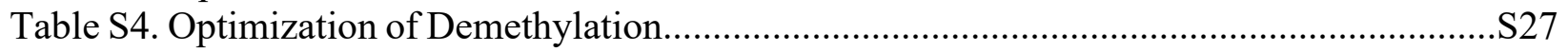

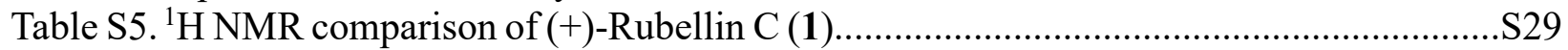

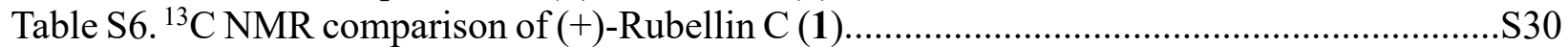

Single Crystal X-Ray Diffraction Data of Phenol 14 and Anthraquinone 19...........................S31

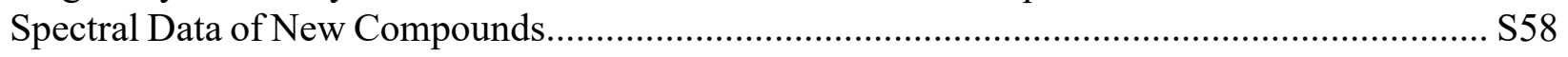

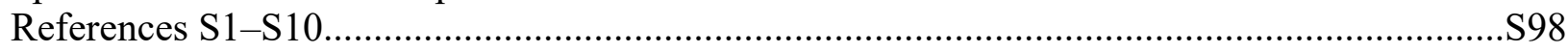




\section{General Information}

All reactions were performed in flame-dried round-bottom flasks capped with septa, $8 \mathrm{~mL}$ capped reaction vials, or $4 \mathrm{~mL}$ capped reaction vials with magnetic stirring under a positive pressure of argon gas and with typical Schlenk line techniques unless otherwise indicated. Commercially obtained reagents were used as received. Solvents were dried by passage through an activated alumina column under argon. Liquids and solutions were transferred via syringe and stainless-steel needle. All reactions were monitored by thin-layer chromatography with E. Merck silica gel 60 F254 pre-coated plates $(0.25 \mathrm{~mm})$ unless otherwise indicated and were visualized by UV $(254 \mathrm{~nm})$ and/or $\mathrm{KMnO}_{4}$ staining. Silica gel (particle size $0.032-0.063 \mathrm{~mm}$ ) purchased from SiliCycle was used for flash chromatography unless otherwise specified. ${ }^{1} \mathrm{H}$ and ${ }^{13} \mathrm{C} \mathrm{NMR}$ spectra were recorded on Varian Inova-500 (500 MHz) spectrometers, Varian Inova-400 (400 and $90 \mathrm{MHz}$, respectively) spectrometers, or Bruker 400 (400 and $101 \mathrm{MHz}$, respectively) spectrometers. Data for ${ }^{1} \mathrm{H}$ NMR spectra are reported relative to chloroform (7.26 ppm), benzene $(7.16 \mathrm{ppm})$, or dimethyl sulfoxide $(2.50 \mathrm{ppm})$ as an internal standard and are reported as follows: chemical shift ( $\delta \mathrm{ppm})$, multiplicity, coupling constant $(\mathrm{Hz})$, and integration. Data for ${ }^{13} \mathrm{C}$ NMR spectra are reported relative to chloroform $(77.0 \mathrm{ppm})$, benzene $(128.1 \mathrm{ppm})$, or dimethyl sulfoxide $(39.5 \mathrm{ppm})$ as an internal standard in terms of chemical shift $(\delta \mathrm{ppm})$. Infrared spectra were recorded on a Mettler Toledo ReactIR 15 with a DST Series $6.3 \mathrm{~mm}$ AgX FiberCoduit $\mathrm{Au} /$ Silicon Probe. HRMS data (ESI) was obtained at the UT Southwestern Metabolomics Core Facility on a SCIEX TripleTOF 6600 High Resolution Accurate Mass System. Optical rotations were measured on a JAS DIP-360 digital polarimeter. X-ray diffraction data was obtained by Dr. Vincent Lynch at the X-ray Diffraction Lab at The University of Texas at Austin.

Figure S1. Positional Numbering

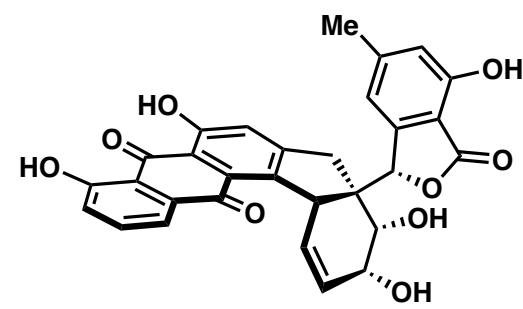

(+)-Rubellin C (1)

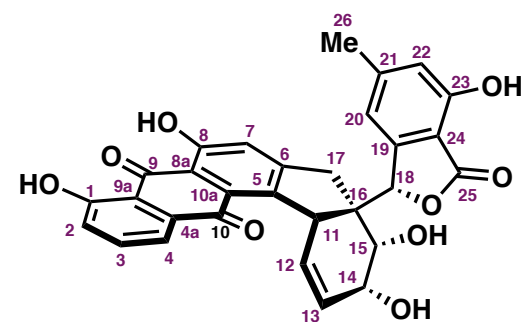

(+)-Rubellin C (1)

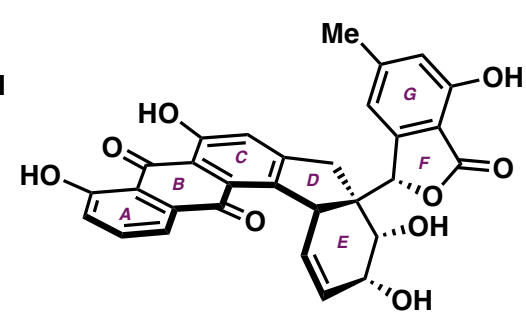

(+)-Rubellin C (1)

The numbering of carbons and rings by Nasini et al is used herein for assignment of intermediates. ${ }^{\text {S1 }}$ Assignments were made by the use of $1 \mathrm{D}$ chemical shifts in ${ }^{1} \mathrm{H}$ and ${ }^{13} \mathrm{C}$ NMR spectra as well as 2D correlations in COSY, HSQC, HMBC, and NOE experiments. Although not containing the same carbon count, the key carbons in the core system are often numbered analogously to the rubellin core scaffold (e.g. C11, C16, and C18). 


\section{Synthetic Procedures for Known Central Enone Component 8}

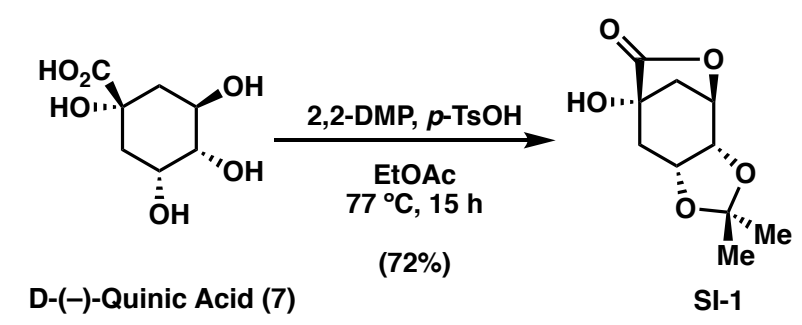

Compound SI-1: A flame-dried $1 \mathrm{~L}$ flask was charged with D-(-)-quinic acid (57.6 g, $300 \mathrm{mmol})$, p-toluenesulfonic acid monohydrate $(656 \mathrm{mg}, 3.45 \mathrm{mmol}), 2$,2-dimethoxypropane $(115 \mathrm{~mL}, 942$ $\mathrm{mmol}$ ), and EtOAc (Sigma Aldrich, HPLC grade, $>99.8 \%, 402 \mathrm{~mL}$ ). A condenser was attached, and the mixture was brought to reflux under argon at $80^{\circ} \mathrm{C}$ for 14 hours. The reaction was cooled, quenched by slow addition of aqueous sat. $\mathrm{NaHCO}_{3}$, and extracted with EtOAc (x3, total $\mathrm{V}=1$ L). The organics were washed with aqueous sat. $\mathrm{NaHCO}_{3}$, water, and brine, then dried over $\mathrm{Na}_{2} \mathrm{SO}_{4}$. The organics were filtered and concentrated to give a crude solid, which was recrystallized from $50 \% \mathrm{CHCl}_{3} /$ hexanes to give lactol $\mathbf{S I}-1$ as white needles $(46.6 \mathrm{~g}, 216.5 \mathrm{mmol}$, 72\%) which matched spectral data from the literature. ${ }^{\mathrm{S} 2}{ }^{1} \mathbf{H}$ NMR (500 $\left.\mathbf{~ M H z}, \mathbf{C D C l}_{\mathbf{3}}\right): \delta 4.72(\mathrm{dd}$, $J=6.2,2.5 \mathrm{~Hz}, 1 \mathrm{H}), 4.49 \mathrm{td}, J=6.0,2.0 \mathrm{~Hz}, 1 \mathrm{H}), 4.31$ (ddd, $J=6.4,2.5,1.4 \mathrm{~Hz}, 1 \mathrm{H}), 2.70(\mathrm{~s}$, $1 \mathrm{H}), 2.65(\mathrm{~d}, J=11.7 \mathrm{~Hz}, 1 \mathrm{H}), 2.41-2.25(\mathrm{~m}, 2 \mathrm{H}), 2.18(\mathrm{dd}, J=14.8,2.8 \mathrm{~Hz}, 1 \mathrm{H}), 1.52(\mathrm{~s}, 3 \mathrm{H})$, $1.33(\mathrm{~s}, 3 \mathrm{H})$.

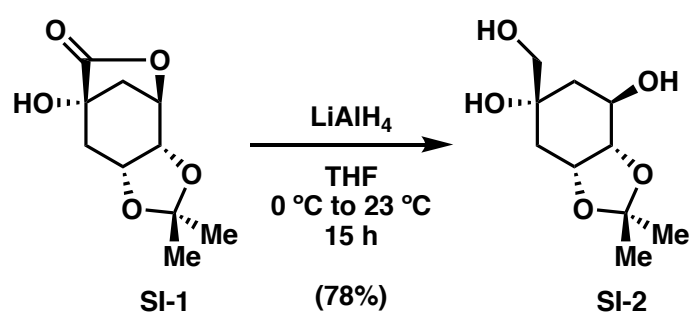

Compound SI-2: A flame-dried $500 \mathrm{~mL}$ 2-neck flask was charged with THF (150 mL, $0.27 \mathrm{M})$ and cooled to $0{ }^{\circ} \mathrm{C}$. $\mathrm{LiAlH}_{4}(4.60 \mathrm{~g}, 120 \mathrm{mmol}, 3$ equiv) was added in portions with a positive pressure of argon and strong stirring. The mixture was allowed to cool in the ice bath with stirring, and lactol SI-1 ( $8.6 \mathrm{~g}, 40 \mathrm{mmol})$ was added from a flame-dried $250 \mathrm{~mL}$ pear flask in THF $(50 \mathrm{~mL}$, $0.8 \mathrm{M}$ ) dropwise. The mixture was then brought to room temperature (note: high rpm stirring is often required to keep the mixture mobile). After 15 hours, $30 \mathrm{~mL}$ THF was used to wash the residual lumps off the sides of the flask. The mixture was cooled to $0{ }^{\circ} \mathrm{C}$, and the reaction was carefully quenched dropwise by the following sequence: $\mathrm{H}_{2} \mathrm{O}(2.4 \mathrm{~mL}), 1 \mathrm{M} \mathrm{NaOH}(7.2 \mathrm{~mL}), \mathrm{H}_{2} \mathrm{O}$ $(7.2 \mathrm{~mL})$. Celite ${ }^{\circledR}(20 \mathrm{~g})$ was added and the slurry was stirred for 2 hours at room temperature. The off-white mixture was filtered over a Celite ${ }^{\circledR}$ pad, and the residual solid was washed with hot EtOAc $(300 \mathrm{~mL})$. The filtrate was evaporated to give the title triol SI-2 as a white solid $(6.8 \mathrm{~g}$, $78 \%$ ), which could be directly used in the next step. The reaction was typically run in duplicate, and the two batches could be combined and carried forward after filtration. Spectral data matched the reported literature values. ${ }^{\mathrm{S} 2, \mathrm{~S} 3}{ }^{1} \mathbf{H}$ NMR (400 $\left.\mathbf{~ M H z}, \mathbf{C D C l}_{3}\right): \delta 4.50$ (ddd, $J=6.0,3.7,2.6 \mathrm{~Hz}$, $1 \mathrm{H}), 4.11$ (ddt, $J=10.3,6.3,4.0 \mathrm{~Hz}, 1 \mathrm{H}), 3.97$ (t, $J=6.0 \mathrm{~Hz}, 1 \mathrm{H}), 3.56-3.44(\mathrm{~m}, 1 \mathrm{H}), 3.40$ (ddd, $J=10.8,7.4,1.1 \mathrm{~Hz}, 1 \mathrm{H}), 3.21$ (s, $1 \mathrm{H}), 2.33-2.21(\mathrm{~m}, 2 \mathrm{H}), 2.01$ (ddd, $J=13.7,4.5,2.3 \mathrm{~Hz}, 1 \mathrm{H})$, 1.85 (dd, $J=15.7,3.7 \mathrm{~Hz}, 1 \mathrm{H}), 1.56(\mathrm{~d}, J=10.1 \mathrm{~Hz}, 3 \mathrm{H}), 1.52-1.44(\mathrm{~m}, 1 \mathrm{H}), 1.38$ (s, $3 \mathrm{H})$. 


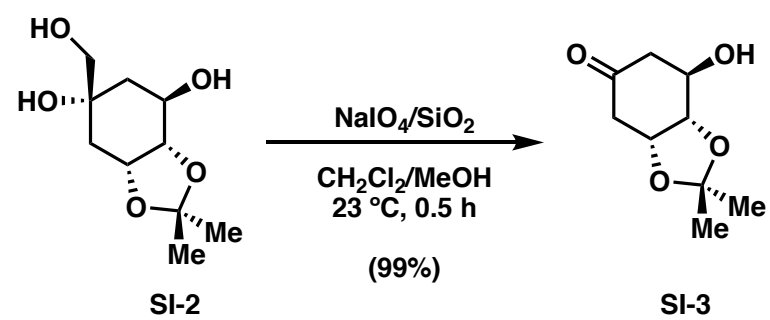

Compound SI-3: Shing's reagent ${ }^{\mathrm{S} 3}$ ( $\mathrm{NaIO}_{4}$ adsorbed on silica gel) was prepared by dissolving $\mathrm{NaIO}_{4}\left(19.1 \mathrm{~g}, 89.4 \mathrm{mmol}, 1.5\right.$ equiv) in $\mathrm{H}_{2} \mathrm{O}(42.1 \mathrm{~mL})$ in an $85{ }^{\circ} \mathrm{C}$ oil bath, followed by the addition of silica gel $(90.0 \mathrm{~g})$ to the hot solution in portions. The flask was removed from the oil bath, and the uneven powder was comprehensively mixed and shaken until it became a fine powder. Meanwhile, compound SI-2 (13.0 g, $59.6 \mathrm{mmol})$ was dissolved in $\mathrm{CH}_{2} \mathrm{Cl}_{2}(397 \mathrm{~mL}, 0.15 \mathrm{M})$ and $\mathrm{MeOH}\left(20 \mathrm{~mL}, 5 \% \mathrm{v} / \mathrm{v}\right.$ with $\left.\mathrm{CH}_{2} \mathrm{Cl}_{2}\right)$. Once dissolved, the cooled and particulate Shing's reagent was added in portions with vigorous stirring. The mixture was stirred for 30 minutes, upon which it was filtered over a Celite ${ }^{\circledR}$ pad and filter paper in a Büchner funnel. The remnants were washed with $\mathrm{Et}_{2} \mathrm{O}(400 \mathrm{~mL})$, and the filtrate was concentrated to afford the hydroxyketone $\mathbf{S I}-\mathbf{3}$ as a liquid that solidified at room temperature $(11.0 \mathrm{~g}, 99 \%)$, which could be directly used in the next step. Spectral data matched the reported literature values. ${ }^{\mathrm{S} 3}$, S4 ${ }^{1} \mathbf{H}$ NMR (500 $\left.\mathbf{M H z}, \mathbf{C D C l}_{3}\right): \delta 4.72$ (dt, $J=6.9,3.3 \mathrm{~Hz}, 1 \mathrm{H}), 4.31$ (dt, $J=7.1,2.3 \mathrm{~Hz}, 1 \mathrm{H}), 4.26$ (s, 1H), $2.84-2.75$ (m, 1H), 2.69 (dd, $J$ $=17.8,2.7 \mathrm{~Hz}, 2 \mathrm{H}), 2.46(\mathrm{ddd}, J=18.0,3.9,1.9 \mathrm{~Hz}, 1 \mathrm{H}), 1.76(\mathrm{~s}, 1 \mathrm{H}), 1.45(\mathrm{~s}, 3 \mathrm{H}), 1.37(\mathrm{~s}, 3 \mathrm{H})$.

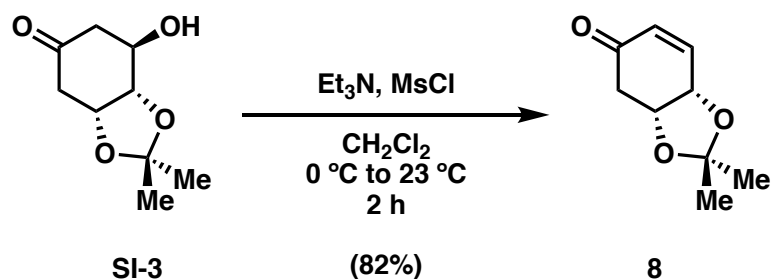

Compound 8: A $500 \mathrm{~mL}$ flask was charged with compound SI-3 (11.0 g, $59 \mathrm{mmol}), \mathrm{CH}_{2} \mathrm{Cl}_{2}$ (333 $\mathrm{mL}, 0.18 \mathrm{M})$, and triethylamine $\left(24.5 \mathrm{~mL}, 177 \mathrm{mmol}, 3\right.$ equiv) and cooled to $0{ }^{\circ} \mathrm{C}$. Methanesulfonyl chloride (5.5 mL, $70.8 \mathrm{mmol}, 1.2$ equiv) in $\mathrm{CH}_{2} \mathrm{Cl}_{2}(60 \mathrm{~mL})$ was added dropwise over 15 minutes to the cold solution. The reaction was removed from the ice bath and stirred at room temperature for 2 hours. At this time, aqueous sat. $\mathrm{NaHCO}_{3}$ was slowly added, and the layers were separated. The aqueous layer was extracted with $\mathrm{CH}_{2} \mathrm{Cl}_{2}(\mathrm{x} 3$, total $\mathrm{V}=800 \mathrm{~mL})$. The organic layers were washed with aqueous sat. $\mathrm{NaHCO}_{3}$, brine, and water, followed by drying over $\mathrm{MgSO}_{4}$, filtration, and concentration to a crude yellow oil. Purification by column chromatography (30\% EtOAc/hexanes) gave the enone $\mathbf{8}$ as a yellow oil, which solidified into a white solid at lower temperatures $(8.13 \mathrm{~g}, 82 \%)$. Spectral data matched the reported literature values. ${ }^{\mathrm{S} 4} \mathbf{1} \mathbf{H}$ NMR (500 MHz, CDCl $\mathbf{l}_{3}$ : $\delta 6.64(\mathrm{ddd}, J=10.4,2.7,1.9 \mathrm{~Hz}, 1 \mathrm{H}), 6.03(\mathrm{dt}, J=10.4,1.2 \mathrm{~Hz}, 1 \mathrm{H}), 4.72$ (ddd, $J=4.3,2.7,1.4 \mathrm{~Hz}, 1 \mathrm{H}), 4.70-4.65(\mathrm{~m}, 1 \mathrm{H}), 2.93(\mathrm{ddd}, J=17.6,2.6,1.0 \mathrm{~Hz}, 1 \mathrm{H}), 2.69(\mathrm{dd}, J=$ 17.6, $3.9 \mathrm{~Hz}, 1 \mathrm{H}), 1.39(\mathrm{~s}, 4 \mathrm{H}), 1.38(\mathrm{~s}, 3 \mathrm{H})$. 


\section{Synthetic Procedures for Benzyl Grignard Fragment 9}

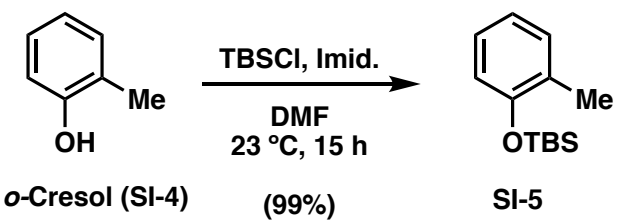

Compound SI-5: A $500 \mathrm{~mL}$ 2-neck flask was charged with $o$-cresol SI-4 $(15.5 \mathrm{~mL}, 150 \mathrm{mmol})$ and DMF $(150 \mathrm{~mL}, 1 \mathrm{M})$. Tert-butyldimethylsilyl chloride $(24.8 \mathrm{~g}, 165 \mathrm{mmol}, 1.1$ equiv) and imidazole ( $22.4 \mathrm{~g}, 330 \mathrm{mmol}, 2.2$ equiv) were added sequentially, and the reaction was stirred for $15 \mathrm{~h}$. The solution was poured into a $2 \mathrm{~L}$ separatory funnel with EtOAc $(700 \mathrm{~mL})$ and $\mathrm{H}_{2} \mathrm{O}(150$ $\mathrm{mL})$. The organics were washed with $\mathrm{H}_{2} \mathrm{O}(150 \mathrm{~mL})$, dried over $\mathrm{Na}_{2} \mathrm{SO}_{4}$, filtered, and concentrated. The concentrate was poured onto a silica plug $(2 \mathrm{CVs}, 1 \%$ EtOAc/hexanes) to give TBS-protected phenol SI-5 as a clear oil (33.3 g, $149 \mathrm{mmol}, 99 \%)$ with spectra that matched the literature. ${ }^{\mathrm{S} 5}{ }^{1} \mathbf{H}$ NMR (500 MHz, CDCl $): \delta 7.16-7.10(\mathrm{~m}, 1 \mathrm{H}), 7.06(\mathrm{t}, J=7.7 \mathrm{~Hz}, 1 \mathrm{H}), 6.86(\mathrm{t}, J=7.4 \mathrm{~Hz}, 1 \mathrm{H})$, $6.77(\mathrm{~d}, J=8.0 \mathrm{~Hz}, 1 \mathrm{H}), 2.21(\mathrm{~s}, 3 \mathrm{H}), 1.02(\mathrm{~s}, 10 \mathrm{H}), 0.22(\mathrm{~s}, 6 \mathrm{H})$.

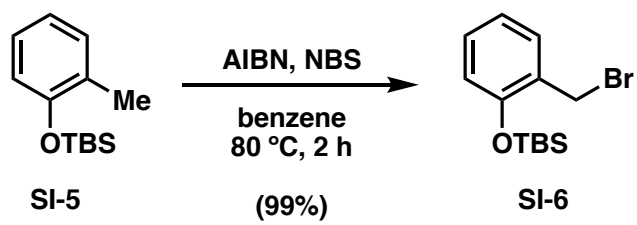

Compound SI-6: A flame-dried $500 \mathrm{~mL}$ 2-neck flask and condenser (note: a long condenser relative to flask size was used, as the reaction is exothermic upon initiation) were charged with $\mathrm{N}$ bromosuccinimide (recrystallized from $\mathrm{H}_{2} \mathrm{O}(10 \mathrm{~g}$ per $\left.100 \mathrm{~mL}), 26.5 \mathrm{~g}, 149 \mathrm{mmol}\right)$ and azobisisobutyronitrile (3.67 g, $22.35 \mathrm{mmol}$ ). Benzene (Sigma Aldrich, ACS Reagent Quality, 298 $\mathrm{mL}, 0.5 \mathrm{M}$ ) was added, followed by TBS-protected cresol SI-5. The mixture was degassed with a flow of argon for 30 minutes, and then submerged into an $80^{\circ} \mathrm{C}$ oil bath. After 2 hours, the flask was removed from the oil bath and allowed to cool. During this period, succinimide precipitated on the walls of the flask. The reaction was diluted with hexanes $(100 \mathrm{~mL})$ and poured over a Celite ${ }^{\circledR}$ plug (2 CVs, hexanes). The resulting liquid was concentrated to an oil, which was purified over a silica plug (2 CVs, hexanes) to furnish bromide SI-6 as a clear oil (44.0 g, 99\%). Spectral data matched the reported literature values. ${ }^{\mathrm{S} 5}{ }^{1} \mathbf{H}$ NMR (500 $\left.\mathbf{~ M H z}, \mathbf{C D C l}_{3}\right): \delta 7.33$ (dd, $J=7.5$, $1.8 \mathrm{~Hz}, 1 \mathrm{H}), 7.18(\mathrm{td}, J=7.7,1.7 \mathrm{~Hz}, 1 \mathrm{H}), 6.92(\mathrm{td}, J=7.5,1.1 \mathrm{~Hz}, 1 \mathrm{H}), 6.81(\mathrm{~d}, J=8.7 \mathrm{~Hz}, 1 \mathrm{H})$, $4.54(\mathrm{~s}, 3 \mathrm{H}), 1.05(\mathrm{~s}, 10 \mathrm{H}), 0.29(\mathrm{~s}, 6 \mathrm{H})$.

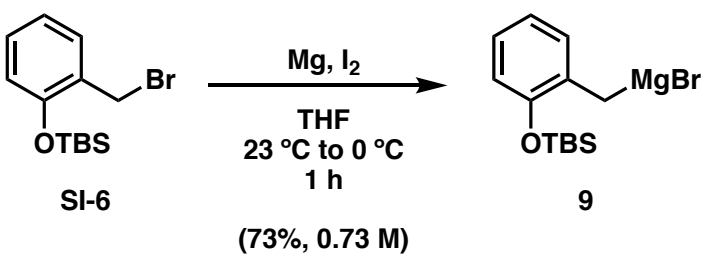

Compound 9: A flame-dried $250 \mathrm{~mL}$ 2-neck flask and condenser were charged with magnesium powder (17.5 g, $730 \mathrm{mmol}$ ), iodine (100 mg), and THF (146 mL, $1 \mathrm{M})$. Benzyl bromide SI-6 (44.0 g) was added to the mixture, which was vigorously stirred. Initiation of the Grignard occurred between 5 and 15 minutes at room temperature with an initial color change from brown to colorless and an exotherm. Upon initiation, the reaction was immediately immersed into an ice bath and stirred for 1 hour at $0{ }^{\circ} \mathrm{C}$. After 1 hour, the cold Grignard reagent 9 was titrated into salicylaldehyde 
phenylhydrazone $(12.2 \mathrm{mg}, 0.057 \mathrm{mml})$ in THF $(1 \mathrm{~mL})$ to afford a titration between 0.68 and 0.78 $\mathrm{M}(68-78 \%$ yield) and was immediately used in the next reaction (see synthesis of compound $\mathbf{1 0})$.

\section{Synthetic Procedures for Known Phthalaldehyde 5}

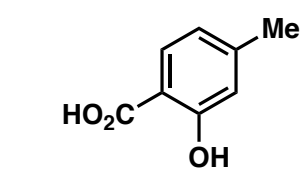

4-methylsalicylic acid (SI-8)

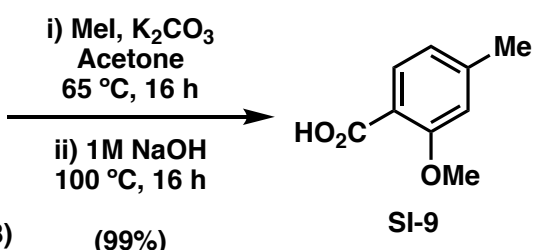

(99\%)

Compound SI-9: 4-methyl salicylic acid SI-8 (7.61 g, $50 \mathrm{mmol})$ was dissolved in acetone (150 $\mathrm{mL}, 0.33 \mathrm{M})$ in a dry flask equipped with a reflux condenser. $\mathrm{K}_{2} \mathrm{CO}_{3}(27.6 \mathrm{~g}, 200 \mathrm{mmol}$, 4 equiv) and MeI (31 mL, $500 \mathrm{mmol}, 10$ equiv) were added to the flask sequentially. The reaction was brought to reflux in a $65{ }^{\circ} \mathrm{C}$ oil bath for $15 \mathrm{~h}$. The mixture was then cooled and filtered over a Buchner funnel. The filter cake was washed with acetone, and the filtrate was concentrated to an oil. The oil was immediately taken up in $1 \mathrm{M}$ aqueous $\mathrm{NaOH}(150 \mathrm{~mL}, 0.33 \mathrm{M})$ and brought to reflux $\left(100{ }^{\circ} \mathrm{C}\right)$ for $15 \mathrm{~h}$. The solution was cooled in a cold-water bath and acidified with concentrated $\mathrm{HCl}$. A white solid precipitated out, which was filtered and dried on vacuum to furnish the methyl ether SI-9 (8.30 g, 99\%). Spectral data matched the reported literature values. ${ }^{\mathrm{S} 6}$

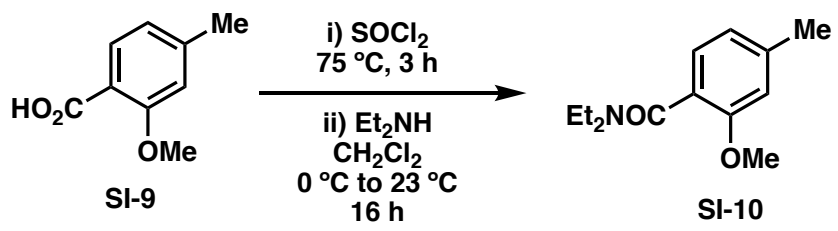

$(62 \%)$

Compound SI-10: Carboxylic acid SI-9 $(8.31 \mathrm{~g}, 8.56 \mathrm{mmol})$ was added to a flask equipped with a reflux condenser. Thionyl chloride $(83 \mathrm{~mL}, 0.6 \mathrm{M})$ was added, and the manifold line was removed and replaced with a line to an external oil bubbler. The solution was refluxed for 3 hours, at which point it was cooled and concentrated on a rotary evaporator (azeotroped with toluene, 20 $\mathrm{mL} \mathrm{x3})$. The crude acid chloride was taken up in $\mathrm{CH}_{2} \mathrm{Cl}_{2}(166 \mathrm{~mL}, 0.3 \mathrm{M})$ and cooled to $0{ }^{\circ} \mathrm{C}$. $\mathrm{Et}_{2} \mathrm{NH}(20.6 \mathrm{~mL}, 34.2 \mathrm{mmol}, 4$ equiv) was added dropwise, and the mixture was allowed to come to room temperature overnight. The mixture was diluted with $\mathrm{CH}_{2} \mathrm{Cl}_{2}(250 \mathrm{~mL})$, washed with water and brine, and dried over $\mathrm{Na}_{2} \mathrm{SO}_{4}$. The organics were filtered and concentrated, followed by purification by flash column chromatography (50\% EtOAc/hexanes) to give the amide SI-10 as a colorless solid (6.84 g, 62\%) Spectral data matched the reported literature values. ${ }^{\text {S6 }}{ }^{1} \mathbf{H}$ NMR (500 MHz, $\left.\mathbf{C D C l}_{3}\right): \delta 7.07(\mathrm{~d}, J=7.5 \mathrm{~Hz}, 1 \mathrm{H}), 6.77$ (ddd, $\left.J=7.6,1.5,0.7 \mathrm{~Hz}, 1 \mathrm{H}\right), 6.70(\mathrm{~s}, 1 \mathrm{H}), 3.80$ (s, 3H), $3.56(\mathrm{~s}, 2 \mathrm{H}), 3.14(\mathrm{q}, J=7.1 \mathrm{~Hz}, 2 \mathrm{H}), 2.36(\mathrm{~s}, 3 \mathrm{H}), 1.23(\mathrm{t}, J=7.1 \mathrm{~Hz}, 3 \mathrm{H}), 1.02(\mathrm{t}, J=$ $7.1 \mathrm{~Hz}, 3 \mathrm{H})$. 


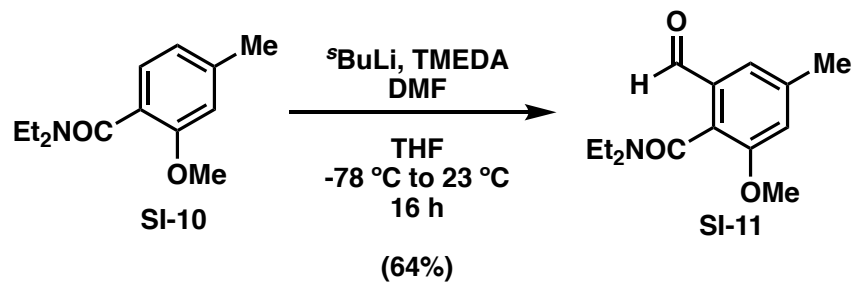

Compound SI-11: A flame-dried flask was charged with THF (74.0 mL, 0.27 M) and cooled to $78{ }^{\circ} \mathrm{C}$. Sec-butyl lithium (1.4 M in cyclohexane, $18.6 \mathrm{~mL}, 26.0 \mathrm{mmol}, 1.3$ equiv) was added, followed by tetramethylenediamine $(3.87 \mathrm{~mL}, 26 \mathrm{mmol}, 1.3$ equiv) to give a yellow solution. Amide SI-10 (4.42 g) in THF (15.3 mL, 1.3 M) was added dropwise over 30 minutes at $-78{ }^{\circ} \mathrm{C}$. The mixture was stirred at $-78{ }^{\circ} \mathrm{C}$ for 30 minutes, at which point DMF $(1.87 \mathrm{~mL}, 24 \mathrm{mmol}, 1.2$ equiv) was added dropwise. The reaction mixture was stirred for 15 minutes at $-78{ }^{\circ} \mathrm{C}$, then allowed to warm to room temperature overnight. The reaction was cooled to $0{ }^{\circ} \mathrm{C}$ and quenched with the slow addition of $6 \mathrm{~N} \mathrm{HCl}$ until $\sim \mathrm{pH}=4$. The layers were separated, and the aqueous layer was extracted with EtOAc $(350 \mathrm{~mL})$. The organics were washed with water and brine, dried over $\mathrm{Na}_{2} \mathrm{SO}_{4}$, filtered, and concentrated to a residue. The title compound was purified by flash column chromatography (50\% EtOAc/hexanes) to give the formylated amide SI-11 as a yellow oil (3.18 g, 64\%). Spectral data matched the reported literature values. ${ }^{\text {S6 }}{ }^{1} \mathbf{H}$ NMR (500 $\left.\mathbf{~ M H z , ~} \mathbf{C D C l}_{3}\right): \delta$ $9.96(\mathrm{~s}, 1 \mathrm{H}), 7.34(\mathrm{~d}, J=0.7 \mathrm{~Hz}, 1 \mathrm{H}), 6.97(\mathrm{~s}, 1 \mathrm{H}), 3.85(\mathrm{~s}, 4 \mathrm{H}), 3.73$ (dq, $J=14.2,7.1 \mathrm{~Hz}, 1 \mathrm{H})$, $3.53(\mathrm{dq}, J=14.1,7.1 \mathrm{~Hz}, 1 \mathrm{H}), 3.11(\mathrm{q}, J=7.2 \mathrm{~Hz}, 2 \mathrm{H}), 2.43(\mathrm{~s}, 3 \mathrm{H}), 1.29$ (t, $J=7.1 \mathrm{~Hz}, 4 \mathrm{H})$, $1.01(\mathrm{t}, J=7.1 \mathrm{~Hz}, 3 \mathrm{H})$.
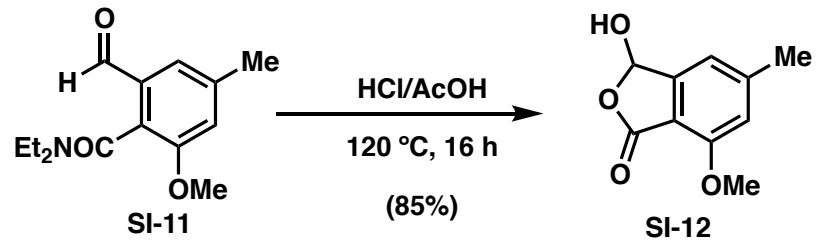

Compound SI-12: Formylated amide SI-11 (2.08 g, $8.36 \mathrm{mmol})$ was dissolved in 1N HCl (38.9 $\mathrm{mL})$ and glacial acetic acid $(19.4 \mathrm{~mL})$, then brought to reflux overnight. The reaction was cooled and concentrated on a rotary evaporator. The brown residue was extracted with EtOAc, and the organics were then extracted with aqueous saturated $\mathrm{NaHCO}_{3}$. The aqueous layer was acidified with concentrated $\mathrm{HCl}$ and re-extracted with EtOAc $(250 \mathrm{~mL})$. The organics were dried on $\mathrm{Na}_{2} \mathrm{SO}_{4}$, filtered, and concentrated to give the title lactol SI-12 (1.38 g, 85\%). Spectral data matched the reported literature values. ${ }^{\mathrm{S} 6}{ }^{1} \mathbf{H}$ NMR $\left(\mathbf{5 0 0} \mathbf{~ M H z}, \mathbf{C D C l}_{3}\right): \delta 6.98(\mathrm{~s}, 1 \mathrm{H}), 6.82(\mathrm{~s}, 1 \mathrm{H}), 6.46(\mathrm{~s}$, $1 \mathrm{H}), 3.98(\mathrm{~s}, 4 \mathrm{H}), 2.48(\mathrm{~d}, J=0.7 \mathrm{~Hz}, 3 \mathrm{H})$.

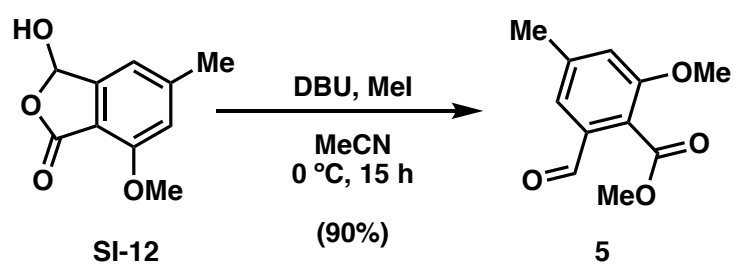

Compound 5: Lactol SI-12 (1.20 g, $6.2 \mathrm{mmol})$ was added to a flame-dried flask and dissolved in acetonitrile $(31 \mathrm{~mL}, 0.2 \mathrm{M})$ then cooled to $0{ }^{\circ} \mathrm{C}$. 1,8-Diazabicyclo[5.4.0]undec-7-ene (DBU) (3.7 $\mathrm{mL}, 24.8 \mathrm{mmol}, 4$ equiv) was added dropwise and the yellow solution was stirred at $0{ }^{\circ} \mathrm{C}$ for 15 minutes. Methyl iodide (1.5 mL, $24.8 \mathrm{mmol}, 4$ equiv) was then added dropwise over 10 minutes at $0{ }^{\circ} \mathrm{C}$. At this point, the Schlenk manifold line was removed and the flask was tightly sealed with 
parafilm and electrical tape, and the flask was moved to a cold room to be stirred at $4{ }^{\circ} \mathrm{C}$ overnight. Afterwards, the reaction mixture was concentrated to a residue, which was partitioned into EtOAc $(100 \mathrm{~mL})$ and $1 \mathrm{~N} \mathrm{HCl}$. The organic layer was washed with $\mathrm{H}_{2} \mathrm{O}$, aqueous saturated $\mathrm{Na}_{2} \mathrm{~S}_{2} \mathrm{O}_{3}$, and brine. The organic layer was then dried on $\mathrm{Na}_{2} \mathrm{SO}_{4}$, filtered, and concentrated, followed by purification by flash column chromatography (30\% EtOAc/hexanes) to give phthalaldehyde $\mathbf{5}$ as a white solid (1.17 g, 90\%). Spectral data matched the reported literature values. ${ }^{\text {S6 }}{ }^{1} \mathbf{H}$ NMR (500 MHz, $\left.\mathbf{C D C l}_{3}\right): \delta 9.93(\mathrm{~s}, 1 \mathrm{H}), 7.27(\mathrm{~d}, J=0.7 \mathrm{~Hz}, 1 \mathrm{H}), 7.01(\mathrm{~s}, 1 \mathrm{H}), 3.96(\mathrm{~s}, 4 \mathrm{H}), 3.87(\mathrm{~s}, 4 \mathrm{H})$, $2.45(\mathrm{~s}, 4 \mathrm{H})$.

\section{Synthetic Procedures for Known Sulphone 18}

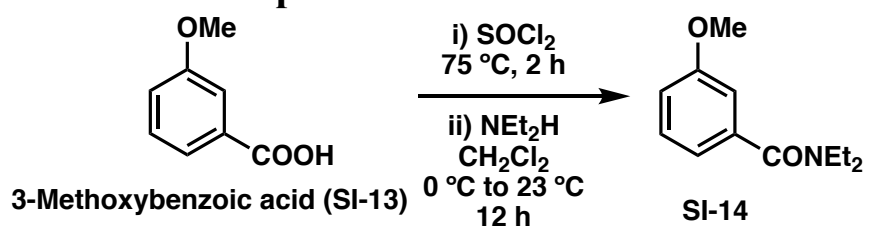

(89\%)

Compound SI-14: 3-methoxybenzoic acid SI-13 (7.61 g, $50 \mathrm{mmol})$ was added to a flame-dried flask equipped with a reflux condenser. Thionyl chloride $(8 \mathrm{~mL}, 110 \mathrm{mmol}, 2.2$ equiv) was added, and the manifold line was removed and replaced with a line to an external oil bubbler. The solution was refluxed for 3 hours, at which point it was cooled and concentrated on a rotary evaporator (azeotroped with toluene, $25 \mathrm{~mL} \times 3)$. The crude acid chloride was taken up in $\mathrm{CH}_{2} \mathrm{Cl}_{2}(38 \mathrm{~mL}, 1.3$ $\mathrm{M})$ and cooled to $0{ }^{\circ} \mathrm{C}$. $\mathrm{Et}_{2} \mathrm{NH}$ (10.34 mL, $100 \mathrm{mmol}, 2$ equiv) was added dropwise in $\mathrm{CH}_{2} \mathrm{Cl}_{2}$ (25 $\mathrm{mL}, 2 \mathrm{M}$ ), and the mixture was allowed to come to room temperature overnight. The mixture was diluted with $\mathrm{CH}_{2} \mathrm{Cl}_{2}(150 \mathrm{~mL})$, washed with water and brine, and dried over $\mathrm{Na}_{2} \mathrm{SO}_{4}$. The organics were filtered and concentrated, followed by purification by vacuum distillation (boiling point 176$178{ }^{\circ} \mathrm{C}$ at 10 mbar) to give the title compound SI-14 as a colorless oil $(9.21 \mathrm{~g}, 89 \%)$ Spectral data matched the reported literature values. ${ }^{\mathrm{S} 7}{ }^{1} \mathbf{H}$ NMR $\left(500 \mathbf{M H z}, \mathbf{C D C l}_{3}\right): \delta 7.30(\mathrm{ddd}, J=8.2,7.5$, $0.6 \mathrm{~Hz}, 1 \mathrm{H}), 6.97-6.86(\mathrm{~m}, 3 \mathrm{H}), 3.82(\mathrm{~s}, 3 \mathrm{H}), 3.54(\mathrm{~d}, J=7.4 \mathrm{~Hz}, 2 \mathrm{H}), 3.25(\mathrm{~d}, J=7.3 \mathrm{~Hz}, 2 \mathrm{H})$, $1.24(\mathrm{~s}, 3 \mathrm{H}), 1.11(\mathrm{~s}, 3 \mathrm{H})$.

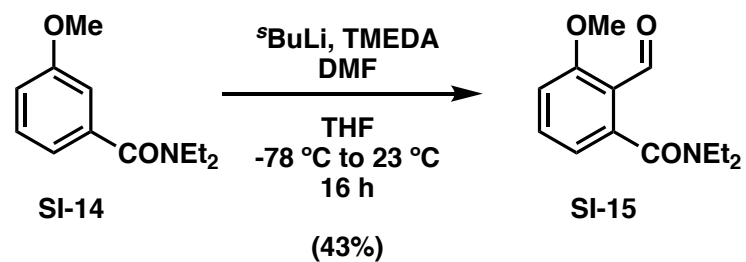

Compound SI-15: The same procedure as compound SI-11 was used for transformation of amide SI-14 (9.21 g) into formylated amide SI-15, however purification was performed with a 0-100\% EtOAc/hexanes gradient $(4.58 \mathrm{~g}, 43 \%)$. Spectral data matched the reported literature values. ${ }^{\mathrm{S} 7}{ }^{1} \mathbf{H}$ NMR (500 MHz, CDCl $\left.)_{3}\right): \delta 10.48(\mathrm{~s}, 1 \mathrm{H}), 7.54(\mathrm{ddd}, J=8.6,7.4,1.2 \mathrm{~Hz}, 1 \mathrm{H}), 7.00(\mathrm{~d}, J=8.5$ $\mathrm{Hz}, 1 \mathrm{H}), 6.84(\mathrm{dd}, J=7.5,1.1 \mathrm{~Hz}, 1 \mathrm{H}), 3.94(\mathrm{~d}, J=1.2 \mathrm{~Hz}, 4 \mathrm{H}), 3.58(\mathrm{~d}, J=7.2 \mathrm{~Hz}, 3 \mathrm{H}), 3.06$ $(\mathrm{qd}, J=7.2,1.3 \mathrm{~Hz}, 3 \mathrm{H}), 1.32(\mathrm{td}, J=7.1,1.3 \mathrm{~Hz}, 4 \mathrm{H}), 1.00(\mathrm{td}, J=7.2,1.3 \mathrm{~Hz}, 4 \mathrm{H})$. 


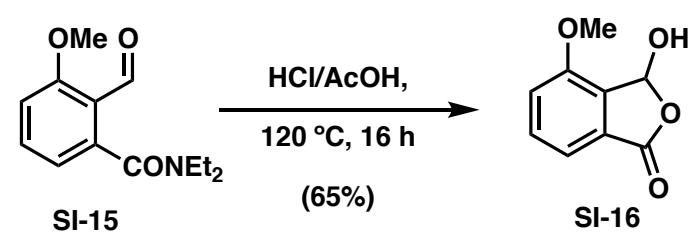

Compound SI-16: The same procedure for compound SI-12 (767 mg, $2.90 \mathrm{mmol}$ ) was used for transformation of SI-15 into the lactol SI-16 as a white solid (342 mg, 65\%). Spectral data matched the reported literature values. ${ }^{\mathrm{S} 7}{ }^{1} \mathbf{H}$ NMR $\left(\mathbf{5 0 0} \mathbf{M H z}, \mathbf{C D C l}_{3}\right): \delta 7.60-7.54(\mathrm{~m}, 1 \mathrm{H}), 7.48(\mathrm{~d}, J=$ $7.6 \mathrm{~Hz}, 1 \mathrm{H}), 7.17(\mathrm{~d}, J=8.1 \mathrm{~Hz}, 1 \mathrm{H}), 6.68(\mathrm{~s}, 1 \mathrm{H}), 3.96(\mathrm{~s}, 3 \mathrm{H})$.

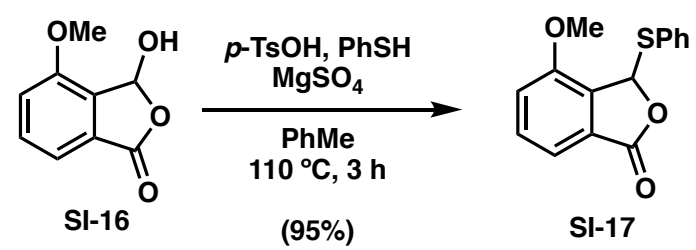

Compound SI-17: Lactol SI-16 (180 mg, $1 \mathrm{mmol}), p$-toluenesulfonic acid hydrate $(8.6 \mathrm{mg}, 0.05$ mmol, $5 \mathrm{~mol} \%), \mathrm{MgSO}_{4}(2 \mathrm{~g}, 1 \mathrm{~g}$ per $\mathrm{mmol} \mathrm{SM})$, and toluene $(5 \mathrm{~mL}, 0.2 \mathrm{M})$ were added to a flask and reflux condenser. Thiophenol $(84 \mu \mathrm{L}, 0.9 \mathrm{mmol}, 0.9$ equiv) was added and the mixture was brought to boil for 3 hours. The mixture was cooled and quenched by the slow addition of aqueous saturated $\mathrm{NaHCO}_{3}$. The mixture was extracted with EtOAc $(100 \mathrm{~mL})$, the organics were washed with aqueous saturated $\mathrm{NaHCO}_{3}$, water, and brine, followed by drying over $\mathrm{Na}_{2} \mathrm{SO}_{4}$, filtration, and concentration on the rotary evaporator. The orange solid SI-17 was used directly in the next step (259 mg, 95\%). Spectral data matched the reported literature values. ${ }^{\text {S }}{ }^{1} \mathbf{H}$ NMR (500 MHz, $\left.\mathbf{C D C l}_{3}\right): \delta 7.48-7.41(\mathrm{~m}, 3 \mathrm{H}), 7.32(\mathrm{dd}, J=7.6,0.7 \mathrm{~Hz}, 1 \mathrm{H}), 7.25-7.16(\mathrm{~m}, 3 \mathrm{H}), 7.11(\mathrm{dd}, J=$ $8.1,0.8 \mathrm{~Hz}, 1 \mathrm{H}), 6.67(\mathrm{~s}, 1 \mathrm{H}), 4.01(\mathrm{~s}, 3 \mathrm{H})$.

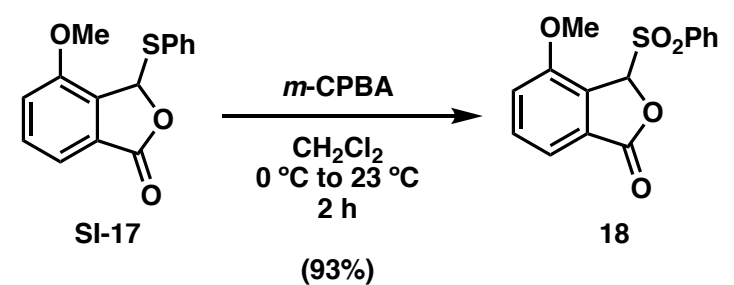

Compound 18: Sulfide SI-17 (259 mg, $0.95 \mathrm{mmol})$ was dissolved in $\mathrm{CH}_{2} \mathrm{Cl}_{2}(9.5 \mathrm{~mL}, 0.1 \mathrm{M})$ and cooled to $0{ }^{\circ} \mathrm{C}$. One portion of $m$-chloroperoxybenzoic acid ( $<77 \%, 328 \mathrm{mg}, 1.9 \mathrm{mmol}$, 2 equiv) was added at $0{ }^{\circ} \mathrm{C}$. The mixture was stirred for 20 minutes at ${ }^{\circ} \mathrm{C}$, then a second portion of $m$-CPBA (164 mg, $0.95 \mathrm{mmol}, 1$ equiv) was added. The mixture was stirred for 30 minutes afterwards and then allowed to come to room temperature and stirred for 1 hour. The reaction was quenched with aqueous saturated $\mathrm{NaHCO}_{3}$ and the layers were separated. The organic layer was dried over $\mathrm{Na}_{2} \mathrm{SO}_{4}$, filtered, and concentrated. Further purification by flash column chromatography $(50 \%$ EtOAc/hexanes) gave the title sulfonated phthalide 18 as a white solid (268 $\mathrm{mg}, 0.88 \mathrm{mmol}, 93 \%)$. Spectral data matched the reported literature values. ${ }^{\mathrm{S} 8}{ }^{1} \mathbf{H}$ NMR (500 $\left.\mathbf{~ M H z}, \mathbf{C D C l}_{3}\right): \delta 7.89$ (dd, $J$ $=8.4,1.3 \mathrm{~Hz}, 3 \mathrm{H}), 7.71-7.64(\mathrm{~m}, 1 \mathrm{H}), 7.63-7.57(\mathrm{~m}, 1 \mathrm{H}), 7.54(\mathrm{dd}, J=8.3,7.5 \mathrm{~Hz}, 3 \mathrm{H}), 7.44$ $(\mathrm{d}, J=7.5 \mathrm{~Hz}, 1 \mathrm{H}), 7.26-7.20(\mathrm{~m}, 2 \mathrm{H}), 6.30(\mathrm{~s}, 1 \mathrm{H}), 4.01(\mathrm{~s}, 5 \mathrm{H})$. 


\section{Synthetic Procedures for Allyl Alcohol 11}

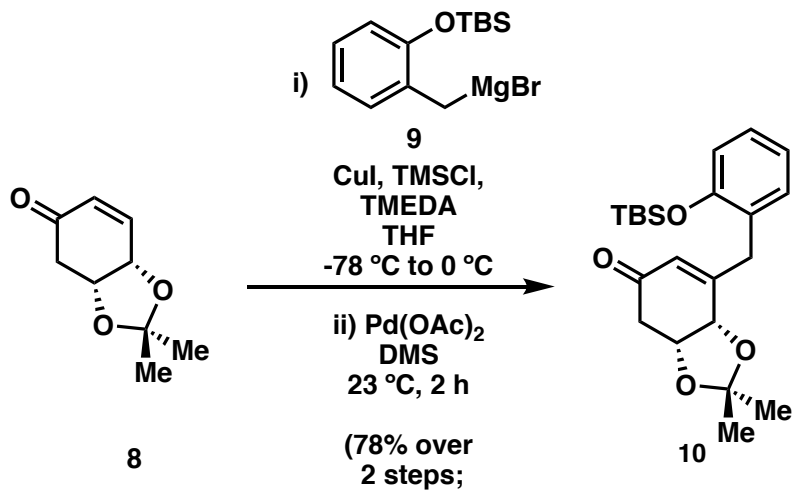

$36 \%$ over 6 steps from 7 )

Compound 10: A $500 \mathrm{~mL}$ 2-neck flask with stir bar was charged with copper(I) iodide (9.14 g, $95 \mathrm{mmol}, 1.6$ equiv) and flame-dried under vacuum. The flask was allowed to cool under vacuum, then blanketed with argon. THF $(150 \mathrm{~mL}, 0.2 \mathrm{M})$ was added, and the mixture was cooled to $0{ }^{\circ} \mathrm{C}$. Freshly prepared Grignard reagent $9(53 \mathrm{~mL}, 0.68 \mathrm{M}, 3.15$ equiv) was added dropwise to the cool solution, during which a black precipitate was observed. The mixture was stirred for 30 minutes at $0{ }^{\circ} \mathrm{C}$. At this time, the flask was transferred to a dry ice/acetone bath and cooled to $-78{ }^{\circ} \mathrm{C}$. During cooling, tetramethylenediamine (TMEDA) $(7.15 \mathrm{~mL}, 48 \mathrm{mmol}, 1.6$ equiv) was added dropwise. Once cooled to $-78^{\circ} \mathrm{C}$, the mixture was charged with enone 8 (5.04 g, $\left.30 \mathrm{mmol}\right)$ and chlorotrimethylsilane (TMSCl) $(6.1 \mathrm{~mL}, 48 \mathrm{mmol}, 1.6$ equiv) in THF (48 mL) dropwise. The deep red mixture was stirred for 3 hours at $-78{ }^{\circ} \mathrm{C}$. After completion of the 1,4 -addition at $-78^{\circ} \mathrm{C}$, the flask was placed in an ice bath at $0{ }^{\circ} \mathrm{C}$ for one hour. Hexanes $(50 \mathrm{~mL})$ and EtOAc $(50 \mathrm{~mL})$ were added to the flask sequentially, followed by careful addition of aqueous sat. $\mathrm{NaHCO}_{3}$. The mixture was filtered, and the filtrate was poured into a separatory funnel. The aqueous layer was separated and extracted $(\mathrm{x} 3,50 \%$ EtOAc/hexanes, total $\mathrm{V}=800 \mathrm{~mL})$. The organics were compiled, washed with aqueous sat. $\mathrm{NaHCO}_{3}$, water (x3), and brine. The organics were dried over $\mathrm{Na}_{2} \mathrm{SO}_{4}$, filtered, and concentrated to a residue. The residue was placed onto a silica plug (3 $\mathrm{CVs}, 50 \%$ EtOAc/hexanes), and the resulting liquid was concentrated to afford a crude mixture of the intermediate silyl enol ether. The silyl enol ether was dissolved in DMSO $(268 \mathrm{~mL}, 0.1 \mathrm{M})$ with vigorous stirring. Palladium(II) acetate ( $6.9 \mathrm{~g}, 30.8 \mathrm{mmol}, 1.03$ equiv) was added, and the reaction was stirred open to air at room temperature for 2 hours. At this time, the reaction was diluted with EtOAc $(200 \mathrm{~mL})$ and filtered over a long Celite ${ }^{\circledR}$ pad. The resulting red liquid was washed with aqueous sat. $\mathrm{NaHCO}_{3}$, water (x3), and brine. The organics were dried over $\mathrm{Na}_{2} \mathrm{SO}_{4}$, filtered, and concentrated to a residue, which was purified by column chromatography ( $15 \% \mathrm{EtOAc} / \mathrm{hexanes})$, to yield the title substituted enone $\mathbf{1 0}$ as a yellow oil $(8.13 \mathrm{~g}, 78 \%)$.

TLC (5:1 Hexanes:EtOAc): $\mathrm{R}_{f} 0.28\left(\mathrm{UV}, \mathrm{KMnO}_{4}\right)$

${ }^{1}$ H NMR (400 MHz, CDCl 3 ): $\delta 7.17-7.08(\mathrm{~m}, 2 \mathrm{H}), 6.90(\mathrm{td}, J=7.4,1.2 \mathrm{~Hz}, 1 \mathrm{H}), 6.82(\mathrm{ddd}, J=$ $377.6,8.0,1.2 \mathrm{~Hz}, 1 \mathrm{H}), 5.67(\mathrm{~s}, 1 \mathrm{H}), 4.64(\mathrm{ddd}, J=5.1,4.0,2.7 \mathrm{~Hz}, 1 \mathrm{H}), 4.58(\mathrm{dd}, J=5.0,1.0 \mathrm{~Hz}$, $1 \mathrm{H}), 3.72(\mathrm{~d}, J=16.4 \mathrm{~Hz}, 1 \mathrm{H}), 3.58(\mathrm{~d}, J=16.7 \mathrm{~Hz}, 1 \mathrm{H}), 2.86(\mathrm{dd}, J=17.4,2.8 \mathrm{~Hz}, 1 \mathrm{H}), 2.60$ (dd, $J=17.4,4.0 \mathrm{~Hz}, 1 \mathrm{H}), 1.41(\mathrm{~d}, J=2.0 \mathrm{~Hz}, 7 \mathrm{H}), 0.97(\mathrm{~s}, 11 \mathrm{H}), 0.23(\mathrm{~d}, J=5.4 \mathrm{~Hz}, 7 \mathrm{H})$.

${ }^{13}$ C NMR (101 MHz, CDCl $\left.\mathbf{l}_{3}\right): \delta 195.6,159.4,154.1,131.5,128.3,127.1,126.3,121.4,118.8$, $109.9,73.5,73.3,39.1,34.3,27.9,26.8,25.9,18.4,-3.9,-3.9$.

FTIR (ReactIR): 1678, 1491, 1372, 1062, 839. 
HRMS (ESI) m/z: $[\mathrm{M}+\mathrm{H}]^{+}$calc. for $\mathrm{C}_{22} \mathrm{H}_{33} \mathrm{O}_{4} \mathrm{Si}$ 389.2143; found 389.2143. $[\alpha]_{\mathbf{D}}^{25}=+42.9^{\circ}(\mathrm{c}=5.0, \mathrm{MeOH})$.
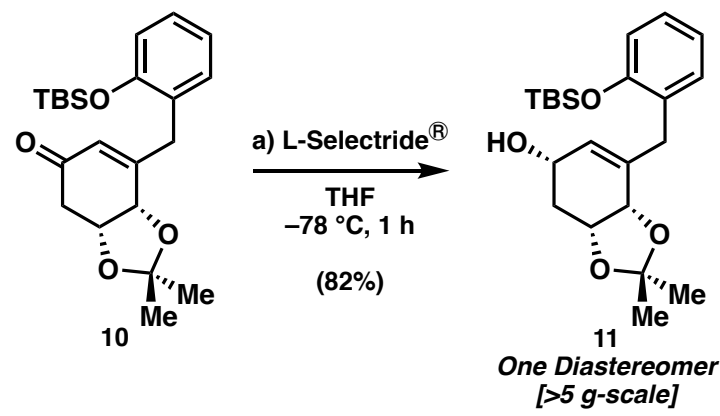

Compound 11: A flame-dried $500 \mathrm{~mL}$ flask was charged with THF (180 mL, $0.12 \mathrm{M})$ and L$\operatorname{Selectride}^{\circledR}(1 \mathrm{M}$ solution in THF, $26.1 \mathrm{~mL})$ and cooled to $-78^{\circ} \mathrm{C}$. Enone $10(8.13 \mathrm{~g}, 20.9 \mathrm{mmol})$ was added dropwise in THF $(29 \mathrm{~mL}, 0.72 \mathrm{M})$, and the reaction was stirred for 1 hour at $-78^{\circ} \mathrm{C}$. Aqueous sat. $\mathrm{NH}_{4} \mathrm{Cl}(26.1 \mathrm{~mL})$ was added dropwise, and the mixture was allowed to come to room temperature. The mixture was poured into a separatory funnel, and $\mathrm{H}_{2} \mathrm{O}(40 \mathrm{~mL})$ and EtOAc $(40$ $\mathrm{mL}$ ) were added. The layers were separated, and the aqueous layer was extracted (x3, EtOAc, final $\mathrm{V}=300 \mathrm{~mL}$ ). The organics were dried over $\mathrm{Na}_{2} \mathrm{SO}_{4}$, filtered, and concentrated to a residue, which was purified by flash column chromatography (5-10\% EtOAc/hexanes), to yield the allylic alcohol 11 as a colorless oil $(6.70 \mathrm{~g}, 82 \%)$.

TLC (3:1 Hexanes:EtOAc): $\mathrm{R}_{f} 0.28\left(\mathrm{UV}, \mathrm{KMnO}_{4}\right)$.

${ }^{1} \mathbf{H}$ NMR (400 MHz, CDCl $\left.\mathbf{C O}_{3}\right): \delta 7.13-7.01(\mathrm{~m}, 2 \mathrm{H}), 6.88(\mathrm{td}, J=7.4,1.2 \mathrm{~Hz}, 1 \mathrm{H}), 6.80(\mathrm{dd}, J=$ $7.9,1.2 \mathrm{~Hz}, 1 \mathrm{H}), 5.58(\mathrm{~d}, J=5.1 \mathrm{~Hz}, 1 \mathrm{H}), 4.51-4.38(\mathrm{~m}, 1 \mathrm{H}), 4.33(\mathrm{~d}, J=5.3 \mathrm{~Hz}, 1 \mathrm{H}), 4.06(\mathrm{q}$, $J=4.4 \mathrm{~Hz}, 1 \mathrm{H}), 3.56(\mathrm{~d}, J=15.6 \mathrm{~Hz}, 1 \mathrm{H}), 3.37(\mathrm{~d}, J=15.6 \mathrm{~Hz}, 1 \mathrm{H}), 2.35-2.21(\mathrm{~m}, 1 \mathrm{H}), 1.94$ (ddd, $J=14.8,4.6,2.6 \mathrm{~Hz}, 1 \mathrm{H}), 1.49$ (s, 3H), 1.37 (s, 3H), 0.99 (s, 10H), $0.23(\mathrm{~s}, 3 \mathrm{H}), 0.22(\mathrm{~s}, 3 \mathrm{H})$. ${ }^{13}$ C NMR (101 MHz, $\left.\mathbf{C D C l}_{3}\right): \delta 154.1,137.6,131.4,129.0,127.5,127.0,121.2,118.7,109.7$, $74.2,73.8,63.8,33.6,32.4,28.3,26.7,25.9,18.4,-3.9,-4.0$.

FTIR (ReactIR): 2931, 1492, 1384, 1253, 1059.

HRMS (ESI) m/z: $[\mathrm{M}+\mathrm{Na}]^{+}$calc. for $\mathrm{C}_{22} \mathrm{H}_{34} \mathrm{O}_{4} \mathrm{SiNa}$ 413.2119; found 413.2130. $[\alpha]_{\mathbf{D}}^{25}=+12.4^{\circ}(\mathrm{c}=10.0, \mathrm{MeOH})$. 


\section{Synthetic Procedures for Rubellin Core 15}
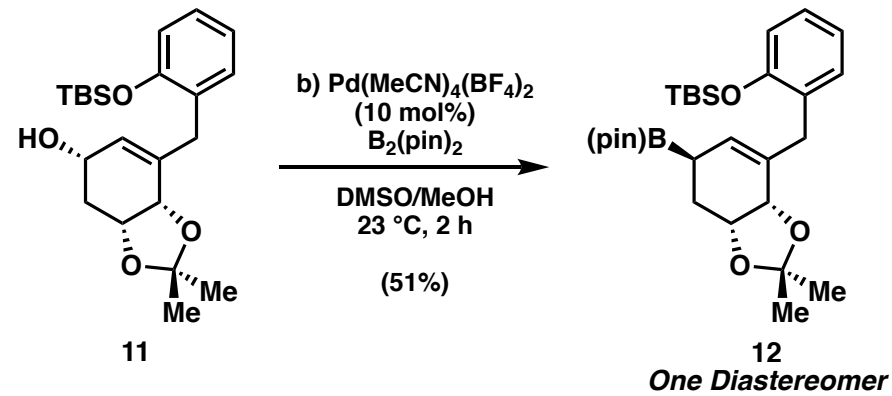

Compound 12: A flame-dried $25 \mathrm{~mL}$ flask was charged with $\mathrm{Pd}(\mathrm{MeCN})_{4}\left(\mathrm{BF}_{4}\right)_{2}(71 \mathrm{mg}, 0.16$ $\mathrm{mmol}, 10 \mathrm{~mol} \%$ ) and $\mathrm{B}_{2}(\mathrm{pin})_{2}(488 \mathrm{mg}, 1.92 \mathrm{mmol}, 1.2$ equiv). DMSO $(2.15 \mathrm{~mL})$ was added to the solids under argon to give an orange mixture. The allylic alcohol $11(625 \mathrm{mg}, 1.6 \mathrm{mmol})$ was added in $\mathrm{MeOH}(2.15 \mathrm{~mL})$. The mixture was stirred at room temperature, slowly turning red, then purple, then black over 2 hours. Methanol was removed on a rotary evaporator at $25^{\circ} \mathrm{C}$. The mixture was treated with $\mathrm{Et}_{2} \mathrm{O}$ and water and extracted with $\mathrm{Et}_{2} \mathrm{O}(\mathrm{x} 3$, final $\mathrm{V}=50 \mathrm{~mL}$ ). The organics were dried on $\mathrm{MgSO}_{4}$, filtered, and concentrated to a residue, which was purified by flash column chromatography ( $10 \%$ EtOAc/hexanes) to give the allylboronic acid pinacol ester $\mathbf{1 2}$ as a white semisolid (400 $\mathrm{mg}, 51 \%$ yield).

TLC (3:1 Hexanes:EtOAc): $\mathrm{R}_{f} 0.71\left(\mathrm{UV}, \mathrm{KMnO}_{4}\right)$.

${ }^{1}$ H NMR (400 MHz, CDCl $): \delta 7.15(\mathrm{dd}, J=7.5,1.8 \mathrm{~Hz}, 1 \mathrm{H}), 7.06(\mathrm{td}, J=7.7,1.8 \mathrm{~Hz}, 1 \mathrm{H}), 6.86$ (td, $J=7.4,1.2 \mathrm{~Hz}, 1 \mathrm{H}), 6.78(\mathrm{~d}, J=8.0 \mathrm{~Hz}, 1 \mathrm{H}), 5.56(\mathrm{~d}, J=3.5 \mathrm{~Hz}, 1 \mathrm{H}), 4.30$ (td, $J=6.3,3.5$ $\mathrm{Hz}, 1 \mathrm{H}), 4.26(\mathrm{~d}, J=6.4 \mathrm{~Hz}, 1 \mathrm{H}), 3.59(\mathrm{~d}, J=15.7 \mathrm{~Hz}, 1 \mathrm{H}), 3.31(\mathrm{~d}, J=15.5 \mathrm{~Hz}, 1 \mathrm{H}), 2.01(\mathrm{~s}$, $1 \mathrm{H}), 1.89$ (ddd, $J=13.4,6.7,5.1 \mathrm{~Hz}, 1 \mathrm{H}), 1.77$ (ddd, $J=13.4,7.8,3.5 \mathrm{~Hz}, 1 \mathrm{H}), 1.42$ (s, 3H), 1.35 (s, 3H), $1.20(\mathrm{~d}, J=1.6 \mathrm{~Hz}, 11 \mathrm{H}), 1.01(\mathrm{~s}, 9 \mathrm{H}), 0.22(\mathrm{~s}, 3 \mathrm{H}), 0.22(\mathrm{~s}, 3 \mathrm{H})$.

${ }^{13} \mathbf{C}$ NMR (101 MHz, $\left.\mathbf{C D C l}_{3}\right): \delta 154.1,133.9,130.9,130.3,127.7,127.0,120.9,118.7,108.3$, $83.4,73.5,34.0,28.2,27.4,26.8,26.0,24.9,24.8,18.4,-3.9,-4.0$.

${ }^{11}$ B NMR (128 MHz, $\left.\mathbf{C D C l}_{3}\right): \delta 33.1$.

FTIR (ReactIR): 1492, 1451, 1372, 1253, 921.

HRMS (ESI) m/z: $[\mathrm{M}+\mathrm{Na}]^{+}$calc. for $\mathrm{C}_{28} \mathrm{H}_{45} \mathrm{O}_{5} \mathrm{SiBNa}$ 523.3022; found 523.3040. $[\alpha]_{\mathbf{D}}^{25}=+15.7^{\circ}\left(\mathrm{c}=1.0, \mathrm{CHCl}_{3}\right)$.

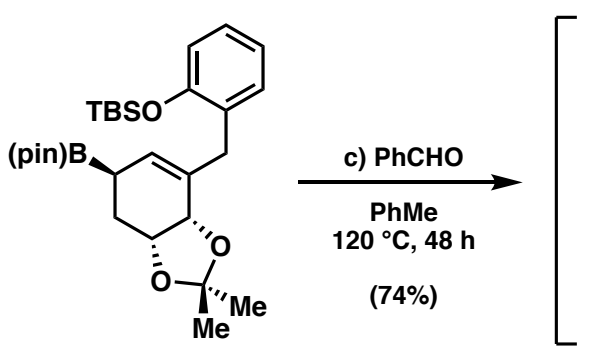

12

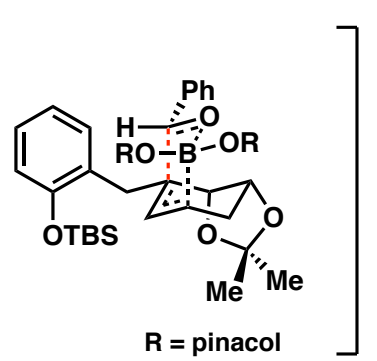

$\mathbf{R}=$ pinacol

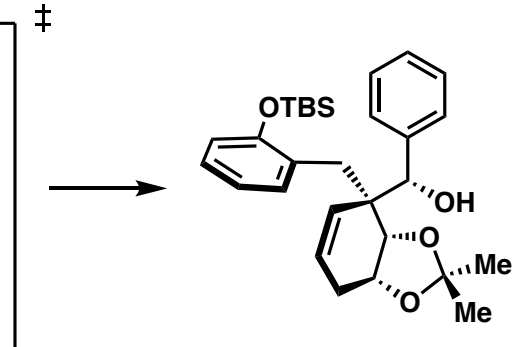

13

Compound 18: An oven-dried microwave vial was charged with allyl boronic ester 12 (230 mg, $0.46 \mathrm{mmol}$ ) as a solution in chloroform, which was sealed with a crimp cap and placed on high vacuum on a Schlenk manifold for at least 3 hours to remove the solvent. Toluene $(4.6 \mathrm{~mL}, 0.1 \mathrm{M})$ was added under argon, followed by benzaldehyde ( $94 \mu \mathrm{L}, 0.92 \mathrm{mmol}, 2$ equiv), and the sealed microwave vial was submerged in a $110^{\circ} \mathrm{C}$ oil bath for $48 \mathrm{~h}$. The reaction was then cooled, 
transferred to a $25 \mathrm{~mL}$ flask, and concentrated on a rotary evaporator. The resulting residue was taken up in EtOAc and saturated aqueous $\mathrm{NH}_{4} \mathrm{Cl}$. The aqueous layer was extracted with EtOAc $(3 \mathrm{x}$, final $\mathrm{V}=50 \mathrm{~mL})$. The organics were washed with brine, dried over $\mathrm{Na}_{2} \mathrm{SO}_{4}$, filtered, and concentrated. Analysis of the crude extract showed one diastereomer of homoallylic alcohol product 13. The title compound was purified by flash column chromatography (50\% $\mathrm{CH}_{2} \mathrm{Cl}_{2} /$ hexanes) to a colorless oil (163 mg, 74\%).

TLC (5:1 Hexanes:EtOAc): $\mathrm{R}_{f} 0.43\left(\mathrm{UV}, \mathrm{KMnO}_{4}\right)$.

${ }^{1} \mathbf{H}$ NMR (400 MHz, $\left.\mathbf{C D C l}_{3}\right): \delta 7.70(\mathrm{dd}, J=7.7,1.8 \mathrm{~Hz}, 1 \mathrm{H}), 7.22-7.11(\mathrm{~m}, 6 \mathrm{H}), 7.01(\mathrm{td}, J=$ 7.5, $1.3 \mathrm{~Hz}, 1 \mathrm{H}), 6.93(\mathrm{dd}, J=8.1,1.3 \mathrm{~Hz}, 1 \mathrm{H}), 5.80(\mathrm{dq}, J=10.4,1.8 \mathrm{~Hz}, 1 \mathrm{H}), 5.72(\mathrm{dt}, J=10.3$, $3.7 \mathrm{~Hz}, 1 \mathrm{H}), 4.31(\mathrm{~d}, J=3.8 \mathrm{~Hz}, 1 \mathrm{H}), 4.21(\mathrm{~d}, J=3.8 \mathrm{~Hz}, 1 \mathrm{H}), 3.78(\mathrm{dd}, J=5.0,1.4 \mathrm{~Hz}, 1 \mathrm{H}), 3.33$ $-3.18(\mathrm{~m}, 2 \mathrm{H}), 2.83(\mathrm{dt}, J=8.4,4.9 \mathrm{~Hz}, 1 \mathrm{H}), 1.78(\mathrm{dddd}, J=18.6,4.7,3.5,2.2 \mathrm{~Hz}, 1 \mathrm{H}), 1.59-$ $1.48(\mathrm{~m}, 2 \mathrm{H}), 1.43(\mathrm{~s}, 3 \mathrm{H}), 1.40(\mathrm{~s}, 3 \mathrm{H}), 1.05(\mathrm{~s}, 9 \mathrm{H}), 0.30(\mathrm{~s}, 3 \mathrm{H}), 0.25(\mathrm{~s}, 3 \mathrm{H})$.

${ }^{13}$ C NMR (101 MHz, CDCl 3$): \delta 154.2,140.4,132.5,128.6,128.4,128.4,128.3,127.9,127.8$, $127.8,127.6,126.4,122.5,120.0,106.7,74.7,49.0,33.1,30.4,28.5,26.1,26.1,26.1,18.6,-3.6$, 4.2 .

FTIR (ReactIR): 2968, 1488, 1246, 1048, 914, 828.

HRMS (ESI) m/z: $[\mathrm{M}+\mathrm{H}]^{+}$calc. for $\mathrm{C}_{29} \mathrm{H}_{41} \mathrm{O}_{4} \mathrm{Si} 481.2769$; found 481.2788. $[\alpha]_{\mathbf{D}}^{25}=-68.8^{\circ}\left(\mathrm{c}=0.5, \mathrm{CHCl}_{3}\right)$.

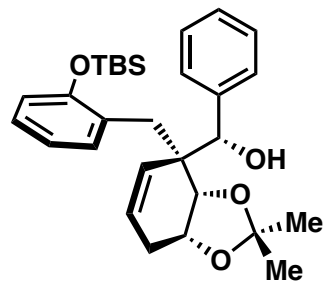

13

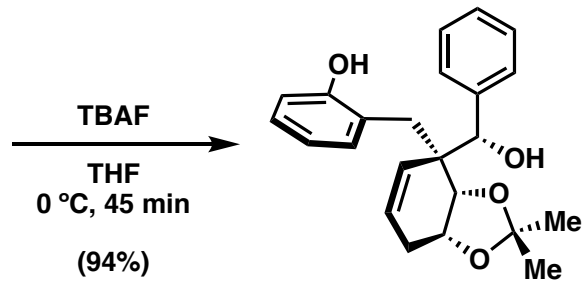

14

Compound 14: A flame-dried $25 \mathrm{~mL}$ flask was charged with TBS-protected phenol 13 (150 mg, $0.31 \mathrm{mmol})$ in THF $(3.1 \mathrm{~mL}, 0.1 \mathrm{M})$. After cooling to $-78{ }^{\circ} \mathrm{C}$, tetra- $n$-butylammonium fluoride (1M in THF, $620 \mu \mathrm{L}, 0.62 \mathrm{mmol}, 2$ equiv) was added dropwise, and the reaction was stirred at $78{ }^{\circ} \mathrm{C}$ for 45 minutes. The reaction was quenched by a $1: 1 \mathrm{~V} / \mathrm{V}$ water:saturated aqueous $\mathrm{NaHCO}_{3}$ solution and extracted with $\mathrm{CH}_{2} \mathrm{Cl}_{2}(\mathrm{x} 3$, final $\mathrm{V}=30 \mathrm{~mL})$. The organics were dried over $\mathrm{MgSO}_{4}$, filtered, and concentrated to a solid residue, which was purified by flash column chromatography (20\% EtOAc/hexanes) to yield the free phenol 14 as a white solid (107 mg, 94\%).

TLC (5:1 Hexanes:EtOAc): $\mathrm{R}_{f} 0.13\left(\mathrm{UV}, \mathrm{KMnO}_{4}\right)$.

${ }^{1}$ H NMR (400 MHz, $\left.\mathbf{C D C l}_{3}\right): \delta 8.27(\mathrm{~s}, 1 \mathrm{H}), 7.57(\mathrm{dd}, J=8.1,1.7 \mathrm{~Hz}, 1 \mathrm{H}), 7.39-7.23(\mathrm{~m}, 5 \mathrm{H})$, $7.19(\mathrm{td}, J=7.6,1.7 \mathrm{~Hz}, 1 \mathrm{H}), 6.89$ (t, $J=7.0 \mathrm{~Hz}, 2 \mathrm{H}), 5.77$ (dddd, $J=12.1,10.4,7.7,2.7 \mathrm{~Hz}, 2 \mathrm{H})$, $4.60(\mathrm{~s}, 1 \mathrm{H}), 3.84(\mathrm{dd}, J=5.2,1.4 \mathrm{~Hz}, 1 \mathrm{H}), 3.23(\mathrm{q}, J=14.3 \mathrm{~Hz}, 2 \mathrm{H}), 2.98(\mathrm{ddd}, J=8.8,5.2,3.9$ $\mathrm{Hz}, 1 \mathrm{H}), 2.53(\mathrm{~s}, 1 \mathrm{H}), 1.85-1.71(\mathrm{~m}, 1 \mathrm{H}), 1.45(\mathrm{~s}, 4 \mathrm{H}), 1.37(\mathrm{~s}, 3 \mathrm{H})$.

${ }^{13}$ C NMR (101 MHz, $\left.\mathbf{C D C l}_{3}\right): \delta$ 156.4, 140.5, 133.5, 128.9, 128.4, 128.3, 128.3, 127.3, 126.9, $122.8,120.1,117.0,107.4,76.7,75.2,70.8,47.9,34.8,30.6,28.1,26.1$.

FTIR (ReactIR): 2976, 1581, 1492, 1380, 1246, 1048.

HRMS (ESI) m/z: $[\mathrm{M}+\mathrm{Na}]^{+}$calc. for $\mathrm{C}_{23} \mathrm{H}_{26} \mathrm{O}_{4} \mathrm{Na} 389.1723$; found 389.1740. $[\alpha]_{\mathrm{D}}^{25}=-48.9^{\circ}\left(\mathrm{c}=1.75, \mathrm{CHCl}_{3}\right)$. 


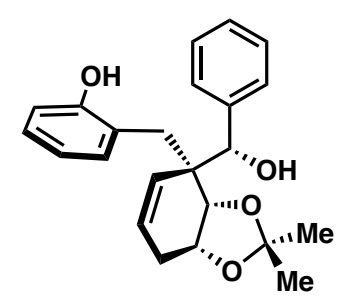

14

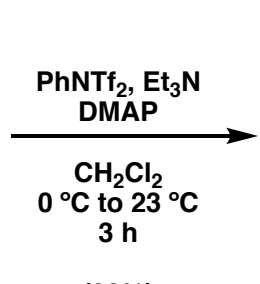

$(98 \%)$

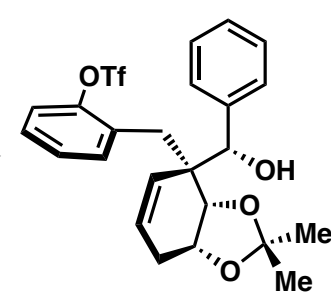

SI-18

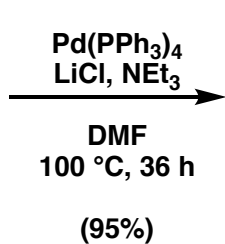

$(95 \%)$

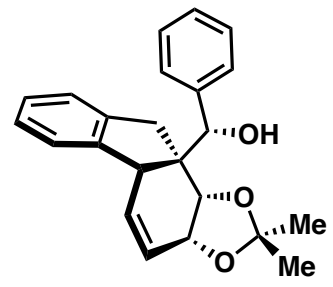

15

One Diastereomer

Compound 15: A flame-dried $25 \mathrm{~mL}$ flask was charged with free phenol 14 (100 mg, $0.27 \mathrm{mmol})$, $\mathrm{PhNTf}_{2}$ (147 mg, $0.41 \mathrm{mmol}, 1.5$ equiv), and DMAP (4 mg, $0.03 \mathrm{mmol}, 10 \mathrm{~mol} \%$ ). Added $\mathrm{CH}_{2} \mathrm{Cl}_{2}$ $(2.7 \mathrm{~mL}, 0.1 \mathrm{M})$ and cooled to $0{ }^{\circ} \mathrm{C}$. At this point, $\mathrm{NEt}_{3}(75 \mu \mathrm{L}, 0.54 \mathrm{mmol}, 2$ equiv) was added. The ice bath was removed, and the reaction was stirred at $23{ }^{\circ} \mathrm{C}$ for 3 hours. Water was added, followed by $\mathrm{CH}_{2} \mathrm{Cl}_{2}$. The mixture was extracted with $\mathrm{CH}_{2} \mathrm{Cl}_{2}(3 \mathrm{x}$, total $\mathrm{V}=25 \mathrm{~mL})$, dried over $\mathrm{Na}_{2} \mathrm{SO}_{4}$, filtered, and concentrated to a residue. The residue was purified by column chromatography $(30 \%$ EtOAc/hexanes) to yield the triflate as a white foam $(132 \mathrm{mg}, 98 \%)$ that was directly used in the Heck reaction. Triflate SI-18 ${ }^{1} \mathbf{H}$ NMR: (400 MHz, $\left.\mathbf{C}_{6} \mathbf{D}_{6}\right): \delta 7.65$ (dd, $J$ $=7.8,1.8 \mathrm{~Hz}, 1 \mathrm{H}), 7.14(\mathrm{~s}, 1 \mathrm{H}), 7.08-6.96(\mathrm{~m}, 5 \mathrm{H}), 6.93(\mathrm{td}, J=7.6,1.3 \mathrm{~Hz}, 1 \mathrm{H}), 6.91-6.78$ $(\mathrm{m}, 3 \mathrm{H}), 5.73(\mathrm{~d}, J=10.4 \mathrm{~Hz}, 1 \mathrm{H}), 5.50(\mathrm{dt}, J=10.2,4.1 \mathrm{~Hz}, 1 \mathrm{H}), 4.29(\mathrm{~s}, 1 \mathrm{H}), 4.01(\mathrm{~d}, J=5.7$ $\mathrm{Hz}, 1 \mathrm{H}), 3.51(\mathrm{~d}, J=14.1 \mathrm{~Hz}, 1 \mathrm{H}), 3.37(\mathrm{~d}, J=13.9 \mathrm{~Hz}, 1 \mathrm{H}), 3.32(\mathrm{dd}, J=8.2,5.4 \mathrm{~Hz}, 1 \mathrm{H}), 1.84$ (dddd, $J=18.1,5.1,3.7,2.5 \mathrm{~Hz}, 1 \mathrm{H}), 1.71$ (dddd, $J=18.1,8.2,4.5,1.9 \mathrm{~Hz}, 1 \mathrm{H}), 1.35$ (s, 4H), 1.28 $(\mathrm{s}, 3 \mathrm{H}) .{ }^{19} \mathrm{~F}$ NMR (400 MHz, $\left.\mathbf{C}_{6} \mathbf{D}_{6}\right): \delta-73.7$. TLC (5:1 Hexanes:EtOac): $\mathrm{R}_{f} 0.28\left(\mathrm{UV}, \mathrm{KMnO}_{4}\right)$. A portion of the triflate SI-18 (32 mg, $0.065 \mathrm{mmol}), \mathrm{Pd}\left(\mathrm{PPh}_{3}\right)_{4}(7.5 \mathrm{mg}, 0.0065 \mathrm{mmol}, 10 \mathrm{~mol} \%)$, and $\mathrm{LiCl}(8.5 \mathrm{mg}, 0.2 \mathrm{mmol}, 3$ equiv) were added to a flame-dried $8 \mathrm{~mL}$ vial and degassed $3 \mathrm{x}$ with argon. DMF $(1.3 \mathrm{~mL})$ and $\mathrm{NEt}_{3}(28 \mu \mathrm{L}, 0.2 \mathrm{mmol}, 3$ equiv) were added, and the mixture was subjected to three freeze-pump-thaw cycles. Once degassed, the vial was submerged in a $100{ }^{\circ} \mathrm{C}$ oil bath for $36 \mathrm{~h}$. The reaction was cooled and quenched with brine. The mixture was extracted with $\mathrm{Et}_{2} \mathrm{O}(\mathrm{x} 3$, total $\mathrm{V}=20 \mathrm{~mL})$, dried over $\mathrm{Na}_{2} \mathrm{SO}_{4}$, filtered, and concentrated. ${ }^{1} \mathrm{H}-\mathrm{NMR}$ analysis of the crude mixture showed one diastereomer. The residue was purified by flash column chromatography (15\% EtOAc/hexanes) to give the core system $\mathbf{1 5}$ of the rubellins as a colorless oil (24 mg, 95\%).

TLC (5:1 Hexanes:EtOAc): $\mathrm{R}_{f} 0.28\left(\mathrm{UV}, \mathrm{KMnO}_{4}\right)$.

${ }^{1}$ H NMR (400 MHz, $\left.\mathbf{C D C l}_{3}\right): \delta 7.33(\mathrm{dd}, J=8.0,1.7 \mathrm{~Hz}, 2 \mathrm{H}), 7.29-7.18(\mathrm{~m}, 4 \mathrm{H}), 7.10-6.93$ (m, 4H), 6.05 (ddd, $J=10.2,4.0,1.4 \mathrm{~Hz}, 1 \mathrm{H}), 5.73(\mathrm{dt}, J=10.2,2.5 \mathrm{~Hz}, 1 \mathrm{H}), 4.85(\mathrm{~s}, 1 \mathrm{H}), 4.58$ (ddt, $J=4.7,3.2,1.7 \mathrm{~Hz}, 1 \mathrm{H}), 4.53(\mathrm{~d}, J=5.7 \mathrm{~Hz}, 1 \mathrm{H}), 3.76(\mathrm{~s}, 1 \mathrm{H}), 3.25(\mathrm{~d}, J=16.2 \mathrm{~Hz}, 1 \mathrm{H})$, $3.04(\mathrm{~d}, J=16.2 \mathrm{~Hz}, 1 \mathrm{H}), 2.46(\mathrm{~d}, J=2.0 \mathrm{~Hz}, 1 \mathrm{H}), 1.24(\mathrm{~s}, 3 \mathrm{H}), 1.10(\mathrm{~s}, 3 \mathrm{H})$.

${ }^{13}$ C NMR (101 MHz, CDCl 3$): \delta 144.5,142.1,141.0,129.3,128.0,128.0,128.0,127.7,127.7$, $126.4,126.0,124.4,123.8,122.4,108.2,80.8,77.0,71.4,53.0,47.0,37.7,27.2,26.3$.

FTIR (ReactIR): 2976, 2365, 1558, 1540, 727.

HRMS (ESI) m/z: $[\mathrm{M}+\mathrm{Na}]^{+}$calc. for $\mathrm{C}_{23} \mathrm{H}_{24} \mathrm{O}_{3} \mathrm{Na} 371.1618$; found 371.1610. $[\alpha]_{\mathbf{D}}^{25}=+35.3^{\circ}\left(\mathrm{c}=1.0, \mathrm{CHCl}_{3}\right)$. 
Figure S2. Attempted Allylations of Aldehyde 5

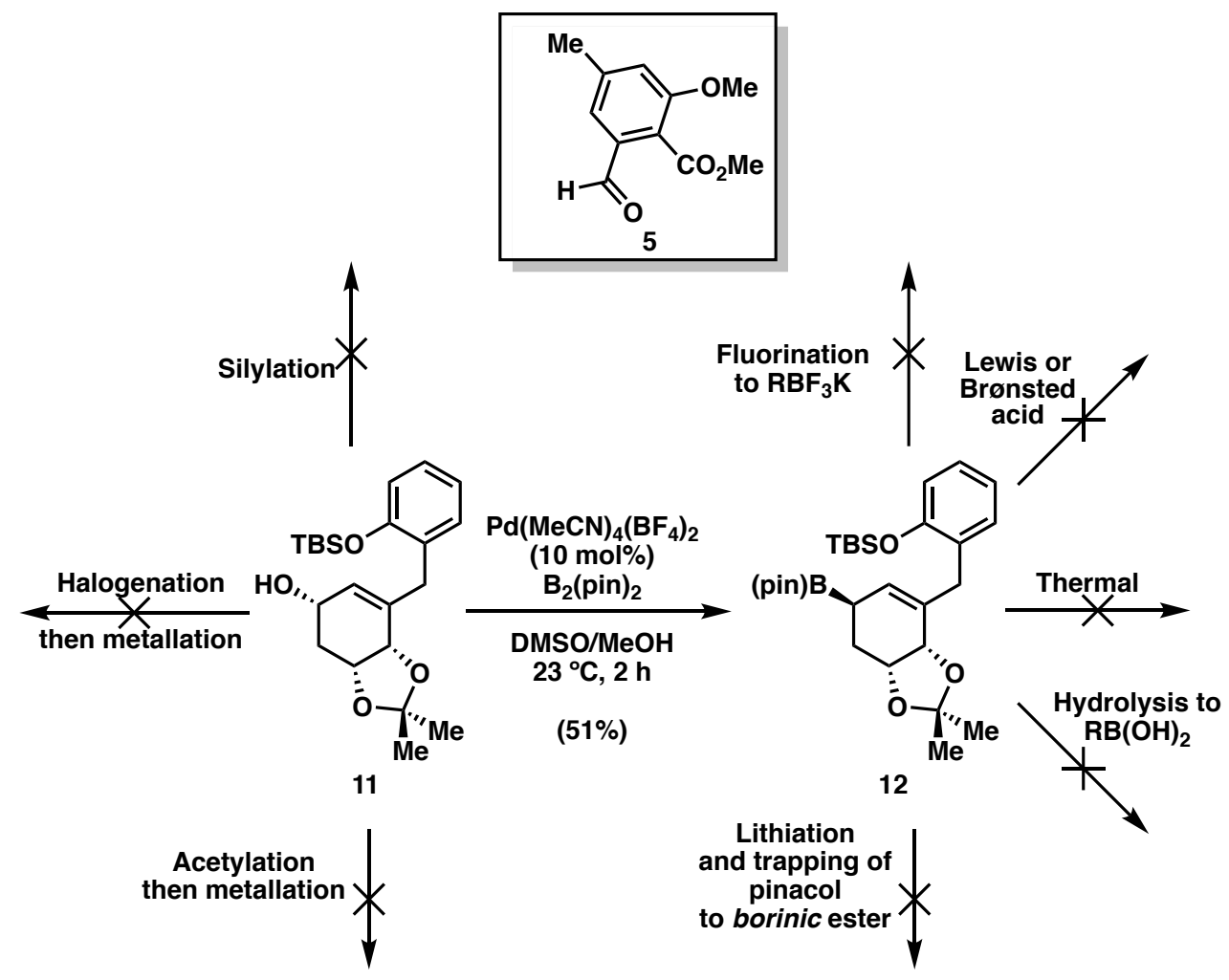

\section{Representative Conditions of Figure S2}

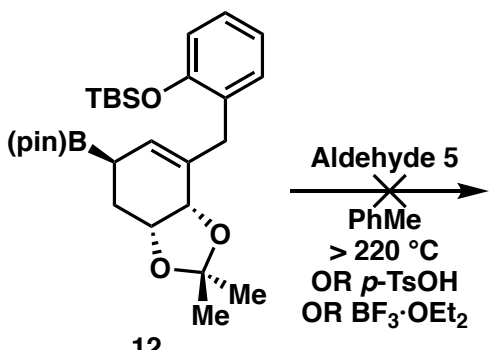

Thermal, Bronsted acid, or Lewis acid promoted allylation attempts: Allyl pinacolboronic ester $12(0.50 \mathrm{mg}, 0.1 \mathrm{mmol})$ was dissolved in toluene $(0.5 \mathrm{M}-0.1 \mathrm{M})$ in a microwave vial charged with excess aldehyde 16. The mixture was either brought to high temperatures $\left(>220{ }^{\circ} \mathrm{C}\right)$ or charged with an acid ( $p$-TsOH or $\mathrm{BF}_{3} \cdot \mathrm{OEt}_{2}$, catalytic to stoichiometric amounts) at $0{ }^{\circ} \mathrm{C}$. In both cases, protodeborylation and decomposition of boronic ester 12 were major pathways. No allylative reactivity was observed by ${ }^{1} \mathrm{H}-\mathrm{NMR}$ or TLC. 


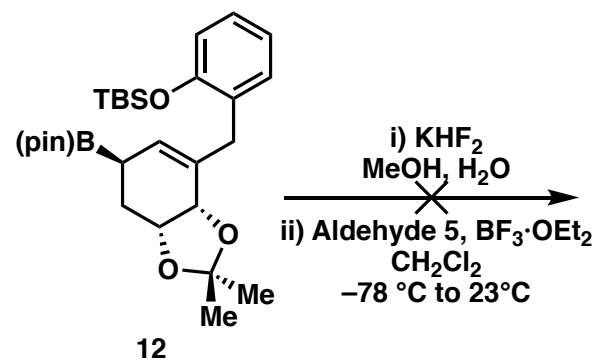

Example of trifluoroborate potassium salt allylation attempt: Allyl pinacolboronic ester $\mathbf{1 2}$ $(0.25 \mathrm{mmol})$ was dissolved in $\mathrm{MeOH}(1.85 \mathrm{~mL})$, to which $\mathrm{KHF}_{2}(39 \mathrm{mg}, 0.5 \mathrm{mmol})$ in $\mathrm{H}_{2} \mathrm{O}(1.85$ $\mathrm{mL}$ ) was added. The mixture was stirred until completion by TLC, which showed multiple isomers. The slurry was evaporated to a crude residue and washed with $\mathrm{Et}_{2} \mathrm{O} /$ hexanes $(10 \mathrm{~mL}$, $10 \%)$. The solid was extracted with acetone to give the crude trifluoroborate potassium salt mixture, which was immediately utilized in the allylation reaction. After dissolving the intermediate in $\mathrm{CH}_{2} \mathrm{Cl}_{2}(2.5 \mathrm{~mL})$ and cooling to $-78{ }^{\circ} \mathrm{C}$, aldehyde 5 (excess) and $\mathrm{BF}_{3} \cdot \mathrm{OEt}_{2}$ (catalytic to excess amounts) were added. Monitoring by TLC and ${ }^{1} \mathrm{H}-\mathrm{NMR}$ to $23{ }^{\circ} \mathrm{C}$ showed trace conversion, upon which decomposition occurred.

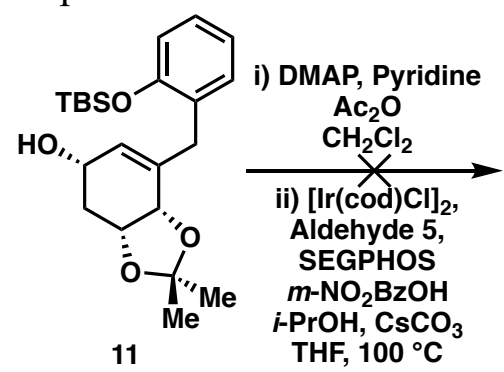

Example of iridium allylation from allyl acetate with Krische catalyst system attempt: A flame-dried vial was charged with allylic alcohol 11 (230 $\mathrm{mg}, 0.59 \mathrm{mmol})$ and 4dimethylaminopyridine ( $7.3 \mathrm{mg}, 0.06 \mathrm{mmol}, 10 \mathrm{~mol} \%)$ in $\mathrm{CH}_{2} \mathrm{Cl}_{2}(1.18 \mathrm{~mL}, 0.5 \mathrm{M})$ then cooled to $0{ }^{\circ} \mathrm{C}$. Pyridine $(142 \mu \mathrm{L}, 1.77 \mathrm{mmol}, 3$ equiv $)$ and acetic anhydride $(67 \mu \mathrm{L}, 0.71 \mathrm{mmol}, 1.2$ equiv) were added sequentially, then the ice bath was removed, and the reaction was stirred at 23 ${ }^{\circ} \mathrm{C}$. The product was purified over a silica plug $(50 \% \mathrm{EtOAc} /$ hexanes $)$ to give the allyl acetate as an oil (194 mg, 76\%). ${ }^{\mathbf{1}} \mathbf{H}$ NMR: (500 MHz, CDCl 3$): \delta 7.15-7.09$ (m, 2H), 6.90 (td, $J=7.4$, $1.2 \mathrm{~Hz}, 1 \mathrm{H}), 6.81(\mathrm{dd}, J=8.1,1.3 \mathrm{~Hz}, 1 \mathrm{H}), 5.36-5.27(\mathrm{~m}, 1 \mathrm{H}), 5.27-5.20(\mathrm{~m}, 1 \mathrm{H}), 4.32(\mathrm{~d}, J=$ $6.0 \mathrm{~Hz}, 1 \mathrm{H}), 4.27(\mathrm{ddd}, J=9.2,6.0,4.5 \mathrm{~Hz}, 1 \mathrm{H}), 3.49(\mathrm{dt}, J=4.1,1.8 \mathrm{~Hz}, 2 \mathrm{H}), 2.13$ (dt, $J=12.1$, $5.0 \mathrm{~Hz}, 1 \mathrm{H}), 2.01(\mathrm{~s}, 3 \mathrm{H}), 1.79(\mathrm{dt}, J=12.4,8.8 \mathrm{~Hz}, 1 \mathrm{H}), 1.49(\mathrm{~s}, 3 \mathrm{H}), 1.37(\mathrm{~s}, 3 \mathrm{H}), 0.99(\mathrm{~s}, 9 \mathrm{H})$, 0.23 (s, 6H). TLC (3:1 Hexanes:EtOAc): $\mathrm{R}_{f} 0.43\left(\mathrm{UV}, \mathrm{KMnO}_{4}\right)$. [ $\left.\mathrm{Ir}(\mathrm{cod}) \mathrm{Cl}\right]_{2}(1.7 \mathrm{mg}, 0.0025$ mmol, $2.5 \mathrm{~mol} \%$ ), aldehyde 5 (excess), (R)- or (S)-SEGPHOS (3.0 mg, $0.005 \mathrm{mmol}, 5 \mathrm{~mol} \%$ ), $m-\mathrm{NO}_{2} \mathrm{BzOH}$ (1.7 mg, $0.01 \mathrm{mmol}, 10 \mathrm{~mol} \%$ ), and $\mathrm{Cs}_{2} \mathrm{CO}_{3}(6.5 \mathrm{mg}, 0.02 \mathrm{mmol}, 20 \mathrm{~mol} \%$ ) were added to a microwave vial. The vial was sealed by crimp cap and purged with argon. Allylic acetate $(43 \mathrm{mg}, 0.1 \mathrm{mmol})$ in THF $(500 \mu \mathrm{L}, 0.2 \mathrm{M})$ was added to the vial, then $i$-PrOH $(15 \mu \mathrm{L}$, $0.2 \mathrm{mmol}, 2$ equiv). The mixture was brought to $100^{\circ} \mathrm{C}$ behind a blast shield. No allylative reactivity was observed by ${ }^{1} \mathrm{H}-\mathrm{NMR}$ or TLC. 

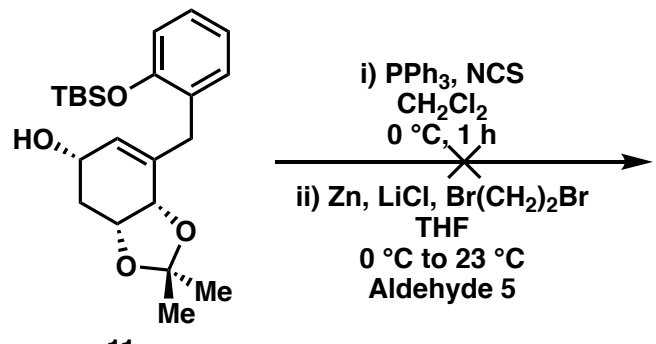

Example of zinc allylation from allyl chloride attempt: A flame-dried vial was charged with allylic alcohol 11 (224 mg, $0.57 \mathrm{mmol})$ and $\mathrm{PPh}_{3}$ (134 mg $0.51 \mathrm{mmol}, 0.9$ equiv). $\mathrm{CH}_{2} \mathrm{Cl}_{2}(2.85$ $\mathrm{mL}, 0.2 \mathrm{M}$ ) was added and the mixture was submerged in a cold water bath. Added $N$ chlorosuccinimide ( $88 \mathrm{mg}, 0.63 \mathrm{mmol}, 1.1$ equiv) in one portion. After $1 \mathrm{~h}$, the mixture was poured over a silica plug ( $3 \mathrm{CVs}, 20 \%$ EtOAc/hexanes) to give the allyl chloride as an oil (150 $\mathrm{mg}, 65 \%$ ). After concentration, the allylic chloride (1 diastereomer) was directly utilized in the resulting metalation reactions. ${ }^{1} \mathbf{H}$ NMR $\left(\mathbf{5 0 0} \mathbf{~ M H z}, \mathbf{C D C l}_{\mathbf{3}}\right): \delta 7.12(\mathrm{ddd}, J=7.4,4.2,2.4 \mathrm{~Hz}$, $2 \mathrm{H}), 6.90(\mathrm{td}, J=7.4,1.2 \mathrm{~Hz}, 1 \mathrm{H}), 6.81(\mathrm{dd}, J=8.5,1.2 \mathrm{~Hz}, 1 \mathrm{H}), 5.46-5.36(\mathrm{~m}, 1 \mathrm{H}), 4.62(\mathrm{dd}$, $J=3.3,1.6 \mathrm{~Hz}, 1 \mathrm{H}), 4.46(\mathrm{td}, J=5.8,3.3 \mathrm{~Hz}, 1 \mathrm{H}), 4.36(\mathrm{~d}, J=5.6 \mathrm{~Hz}, 1 \mathrm{H}), 3.53(\mathrm{~d}, J=16.1 \mathrm{~Hz}$, $1 \mathrm{H}), 3.41(\mathrm{~d}, J=15.9 \mathrm{~Hz}, 1 \mathrm{H}), 2.40(\mathrm{dt}, J=13.9,5.5 \mathrm{~Hz}, 1 \mathrm{H}), 2.07-2.01(\mathrm{~m}, 2 \mathrm{H}), 1.40(\mathrm{~s}, 3 \mathrm{H})$, 1.37 (s, 3H), 0.99 (s, 10H), 0.24 (d, $J=2.6 \mathrm{~Hz}, 6 \mathrm{H})$. TLC (3:1 Hexanes:EtOAc): $\mathrm{R}_{f} 0.51$ (UV, $\left.\mathrm{KMnO}_{4}\right)$. A flame-dried vial was charged with $\mathrm{Zn}$ powder $(86 \mathrm{mg}, 1.32 \mathrm{mmol}, 3.6$ equiv) and $\mathrm{LiCl}(11 \mathrm{mg}, 0.26 \mathrm{mmol}, 0.7$ equiv). After flushing with argon, THF was added, followed by one drop of dibromoethane. The resulting chloride $(150 \mathrm{mg}, 0.37 \mathrm{mmol})$ was added dropwise in THF. (Note: titration at this time never showed $>10 \%$ conversion to the allyl zinc species. $\mathrm{Zn}$ and $\mathrm{LiCl}$ equivalents as well as solvent molarity were screened). Benzaldehyde or aldehyde $\mathbf{5}$ (excess) was added neat, or the mixture was transferred into a solution of benzaldehyde. Trace conversion was observed by ${ }^{1} \mathrm{H}-\mathrm{NMR}$ and TLC.

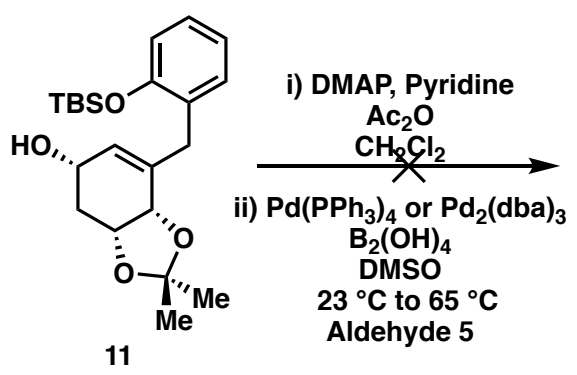

Example of palladium borylation from allyl acetate attempts: The intermediate acetate or chloride was produced from allylic alcohol $\mathbf{1 1}$ as described for the iridium or zinc allylation attempts vide infra. The acetate $(43 \mathrm{mg}, 0.1 \mathrm{mmol})$ was treated with a palladium catalyst (e.g. $\left.\mathrm{Pd}\left(\mathrm{PPh}_{3}\right)_{4}(12 \mathrm{mg}, 0.01 \mathrm{mmol}, 10 \mathrm{~mol} \%)\right)$ in DMSO $(250 \mu \mathrm{L}, 0.4 \mathrm{M})$ with $\mathrm{B}_{2}(\mathrm{OH})_{4}(11 \mathrm{mg}, 0.12$ mmol, 1.2 equiv). No conversion was observed. Degassed chloroform $(1 \mathrm{~mL})$ was added, and the mixture was moved to a vial protected with argon. The mixture was washed with degassed brine $(3 \times 1 \mathrm{~mL})$. The organic layer was transferred to a vial charged with $\mathrm{Na}_{2} \mathrm{SO}_{4}$ under argon and dried for $30 \mathrm{~min}$. The dry organics were moved to another oven-dried vial with stir bar and treated with an excess of benzaldehyde or aldehyde $\mathbf{5}$ overnight. Both the chloride and acetate were examined, as well as diverse catalyst loadings and boron equivalents. No allylative reactivity was observed by ${ }^{1} \mathrm{H}-\mathrm{NMR}$ or TLC. 


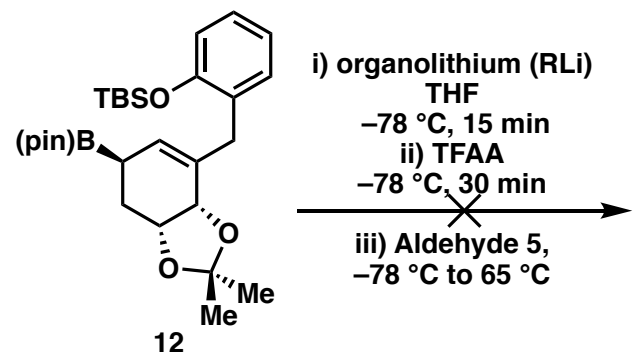

Example of borinic ester formation from allyl pinacolboronic ester 12: A flame dried vial was charged with allyl pinacolboronic ester SI-17 (50 mg, $0.1 \mathrm{mmol})$ in THF (1 mL, 0.1M) and was cooled to $-78^{\circ} \mathrm{C}$. Alkyllithium ( $n$-butyl or methyl, 1.1 equiv) was added dropwise. The yellow solution was stirred for $15 \mathrm{~min}$ at $-78^{\circ} \mathrm{C}$. Trifluoroacetic anhydride $(17 \mu \mathrm{L}, 0.12 \mathrm{mmol}$, 1.2 equiv $)$ was added dropwise, and the solution was stirred at $-78^{\circ} \mathrm{C}$ for $30 \mathrm{~min}$. Excess aldehyde 18 was added in THF, and the reaction was allowed to warm to room temperature. No conversion was observed. The reaction was heated to reflux, upon which significant decomposition occurred, and no allylative reactivity was observed by ${ }^{1} \mathrm{H}-\mathrm{NMR}$.

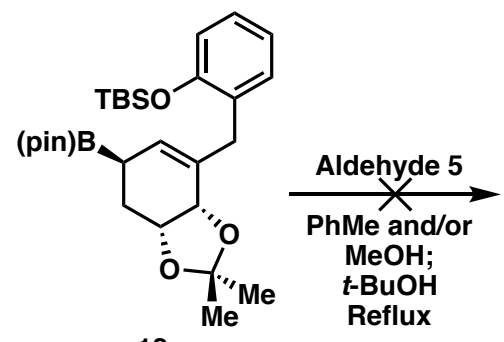

Example of in-situ esterification of allyl pinacolboronic ester 12: Allyl pinacolboronic ester 12 $(0.50 \mathrm{mg}, 0.1 \mathrm{mmol})$ was dissolved in toluene $(0.5 \mathrm{M}-0.1 \mathrm{M})$ with an alcohol additive (tert-butanol or methanol, 5-20 equiv) in a flame-dried vial charged with excess aldehyde 5. The mixture was brought to reflux. In all cases, protodeborylation and decomposition of boronic ester were major pathways. No allylative reactivity was observed by ${ }^{1} \mathrm{H}-\mathrm{NMR}$.

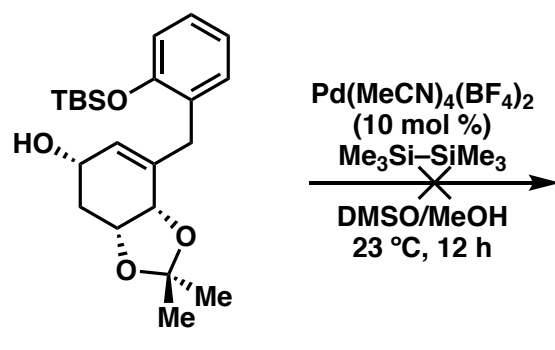

11

Example of palladium-catalyzed silylation attempt: A dry $4 \mathrm{~mL}$ vial with stir bar was charged with allyl alcohol 11 (39 mg, $0.1 \mathrm{mmol})$ and solvent(s). $\mathrm{Pd}(\mathrm{MeCN})_{4}\left(\mathrm{BF}_{4}\right)_{2}$ and hexamethyldisilane ( $25 \mu \mathrm{L}, 0.12 \mathrm{mmol}, 1.2$ equiv) were added and the mixture was stirred at room temperature then heated to $50{ }^{\circ} \mathrm{C}$ and monitored by TLC. Upon loss of starting material, methanol was removed on a rotary evaporator at $25^{\circ} \mathrm{C}$. The mixture was treated with $\mathrm{Et}_{2} \mathrm{O}$ and water and extracted with $\mathrm{Et}_{2} \mathrm{O}$ ( $\mathrm{x} 3$, final $\mathrm{V}=50 \mathrm{~mL}$ ). The organic layers were dried on $\mathrm{MgSO}_{4}$, filtered, and concentrated to a residue, which was analyzed to show a mixture of products with no incorporation of the silyl group. 
Table S1. Optimization of Allylboronic Acid Formation

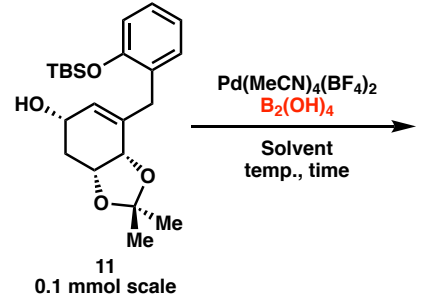

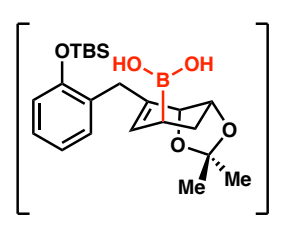

16

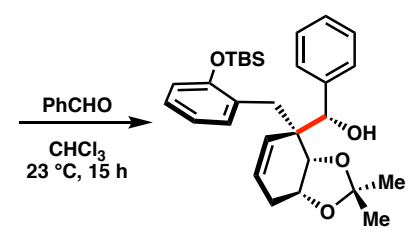

13

\begin{tabular}{|c|c|c|c|c|c|c|c|}
\hline Entry & $\begin{array}{l}\text { catalyst loading } \\
\text { (mol \%) }\end{array}$ & Solvent Mixture & Molarity & Additives (mol \%) & ${ }^{\circ} \mathrm{C}$ & Procedural Changes & Result \\
\hline 1 & 5 & $\mathrm{DMSO} / \mathrm{H}_{2} \mathrm{O} 9: 1$ & 1 & - & 23 & None & $0 \%$ Yield \\
\hline 2 & 5 & DMSO/ $\mathrm{H}_{2} \mathrm{O} 9: 1$ & 1 & - & 23 & $24 \mathrm{~h}$ reaction & $0 \%$ Yield \\
\hline 3 & 5 & $\mathrm{DMSO} / \mathrm{H}_{2} \mathrm{O} 9: 1$ & 1 & - & 23 & Freeze-pump-thaw & $0 \%$ Yield \\
\hline 4 & 10 & $\mathrm{DMSO} / \mathrm{H}_{2} \mathrm{O} 9: 1$ & 1 & - & 23 & None & $0 \%$ Yield \\
\hline 5 & 30 & DMSO/ $\mathrm{H}_{2} \mathrm{O} 9: 1$ & 1 & - & 23 & None & $0 \%$ Yield; significant decomp \\
\hline 6 & 5 & DMSO/H $\mathrm{H}_{2} \mathrm{O} 9: 1$ & 1 & - & 23 & Purified $\mathrm{B}_{2}(\mathrm{OH})_{4}$ & $0 \%$ Yield \\
\hline 7 & 10 & DMSO/H $\mathrm{H}_{2} \mathrm{O} 9: 1$ & 1 & - & 23 & Purified $\mathrm{B}_{2}(\mathrm{OH})_{4}$ & $0 \%$ Yield \\
\hline 8 & 5 & DMSO/ $\mathrm{H}_{2} \mathrm{O}$ 9:1 & 1 & - & 23 & No degassing solvents & $0 \%$ Yield \\
\hline 9 & 5 & DMSO/ $\mathrm{H}_{2} \mathrm{O} 9: 1$ & 1 & - & 23 & Open to air & $0 \%$ Yield \\
\hline 10 & 10 & DMSO/ $\mathrm{H}_{2} \mathrm{O} 9: 1$ & 1 & - & $0-23$ & None & $12.5 \%$ Yield \\
\hline 11 & 10 & DMSO/ $\mathrm{H}_{2} \mathrm{O} 9: 1$ & 1 & - & 23 & $5 \mathrm{~mol} \%$ catalyst at $1 \mathrm{~h}$ & $<5 \%$ Yield \\
\hline 12 & 10 & DMSO/H $\mathrm{H}_{2} \mathrm{O} 9: 1$ & 1 & - & $0-23$ & $30 x$ extraction volume & $13.0 \%$ Yield \\
\hline 13 & 10 & $\mathrm{DMSO} / \mathrm{H}_{2} \mathrm{O} 9: 1$ & 1 & - & $0-23$ & $14 \mathrm{~h}$ reaction & $8 \%$ Yield \\
\hline 14 & 10 & $\mathrm{DMSO} / \mathrm{H}_{2} \mathrm{O} 9: 1$ & 1 & - & $0-23$ & Pd black filtration & $0 \%$ Yield \\
\hline 15 & 10 & DMSO/ $\mathrm{H}_{2} \mathrm{O} 9: 1$ & 1 & - & $0-23$ & PhMe extraction & $0 \%$ Yield \\
\hline 16 & 10 & DMSO/H $\mathrm{H}_{2} \mathrm{O} 9: 1$ & 1 & - & 23 & $\mathrm{H}_{2} \mathrm{O}$ added after solids & $0 \%$ Yield \\
\hline 17 & 10 & DMSO/H ${ }_{2} \mathrm{O} 4: 1$ & 0.75 & - & 23 & None & $0 \%$ Yield \\
\hline 18 & 10 & $\mathrm{DMSO} / \mathrm{H}_{2} \mathrm{O}$ 19:1 & 0.75 & - & 23 & None & $8 \%$ Yield \\
\hline 19 & 10 & DMSO & 0.75 & - & 23 & None & $16 \%$ Yield \\
\hline 20 & 10 & DMSO/H ${ }_{2} \mathrm{O} 9: 1$ & 1 & - & 23 & None & $0 \%$ Yield \\
\hline 21 & 10 & DMSO/MeOH 1:1 & 0.5 & - & $0-23$ & None & $17 \%$ Yield; significant decomp \\
\hline 22 & 10 & DMSO/MeOH 1:1 & 0.5 & - & $0-23$ & SM added to solids & $0 \%$ Yield \\
\hline 23 & 10 & DMSO/MeOH 5:1 & 0.65 & - & 23 & None & $19 \%$ Yield \\
\hline 24 & 10 & DMSO/MeOH 6:1 & 0.65 & - & 23 & None & $18 \%$ Yield \\
\hline 25 & 10 & DMSO/MeOH 2.7:1 & 0.65 & - & 23 & None & $13 \%$ Yield \\
\hline 26 & 10 & DMSO/MeOH (5:1) & 0.65 & - & 23 & $\mathrm{Pd} \rightarrow 30 \mathrm{~min} \rightarrow \mathrm{B}_{2}(\mathrm{OH})_{4}$ & $0 \%$ Yield \\
\hline 27 & 10 & DMSO/MeOH (5:1) & 0.65 & - & 23 & $\mathrm{Pd} \rightarrow>1 \mathrm{~h} \rightarrow \mathrm{B}_{2}(\mathrm{OH})_{4}$ & $0 \%$ Yield \\
\hline 28 & 10 & DMSO/MeOH (5:1) & 0.65 & _- & 35 & None & $0 \%$ Yield; significant decomp \\
\hline 29 & 10 & DMSO/MeOH/ $\mathrm{H}_{2} \mathrm{O}(15: 3: 1)$ & :1) 0.65 & - & 23 & None & $<5 \%$ Yield; significant decomp \\
\hline 30 & 10 & DMSO/MeOH (5:1) & 0.65 & - & 23 & 3 equiv. $\mathrm{B}_{2}(\mathrm{OH})_{4}$ & $0 \%$ Yield \\
\hline 31 & 10 & DMSO/MeOH (5:1) & 0.65 & - & 23 & 2 equiv. $\mathrm{B}_{2}(\mathrm{OH})_{4}+1$ at $2 \mathrm{~h}$ & $10 \%$ Yield \\
\hline 32 & 10 & DMSO/MeOH (5:1) & 0.65 & - & 23 & 1 equiv. $\mathrm{B}_{2}(\mathrm{OH})_{4}+1$ at $2 \mathrm{~h}$ & $19 \%$ Yield \\
\hline 33 & 10 & DMSO/MeOH $(5: 1)$ & 0.65 & $p$-TsOH (10\%) & 23 & None & $0 \%$ Yield \\
\hline 34 & 10 & DMSO/MeOH (5:1) & 0.65 & KOAC $(10 \%)$ & 23 & None & $11 \%$ Yield \\
\hline 35 & 10 & DMSO/MeOH (5:1) & 0.65 & $\mathrm{CuCl}_{2}(10 \%)$ & 23 & None & $10 \%$ Yield \\
\hline 36 & 10 & DMSO/MeOH (5:1) & 0.65 & $\mathrm{CuCl}_{2}$ and $\mathrm{KOAC}(10 \%)$ & 23 & None & $11 \%$ Yield \\
\hline
\end{tabular}

General procedure for allylboronic acid optimization: ${ }^{\mathrm{S} 9}$ A dry $4 \mathrm{~mL}$ vial with stir bar was charged with allyl alcohol 11 (39 mg, $0.1 \mathrm{mmol})$ and solvent(s) under argon. $\mathrm{Pd}(\mathrm{MeCN})_{4}\left(\mathrm{BF}_{4}\right)_{2}$ and $\mathrm{B}_{2}(\mathrm{OH})_{4}(11 \mathrm{mg}, 0.12 \mathrm{mmol}, 1.2$ equiv) were added consecutively and the mixture was stirred under argon. After $6 \mathrm{~h}$, degassed chloroform $(1 \mathrm{~mL})$ was added, and the mixture was moved to a vial protected with argon. The mixture was washed with degassed brine $(3 \times 1 \mathrm{~mL})$. The organic layer was transferred to a vial charged with $\mathrm{Na}_{2} \mathrm{SO}_{4}$ under argon and dried for $30 \mathrm{~min}$. The dry organics were moved to another argon-filled oven-dried vial with stir bar and treated with an excess of benzaldehyde overnight. Rotary evaporation of the solution gave an oil that was analyzed by ${ }^{1} \mathrm{H}-\mathrm{NMR}$ with 1,4-dimethoxybenzene as a standard for yield of allylation product $\mathbf{1 3}$. Unless noted otherwise, starting material could be recovered from each reaction, and the product was formed as one diastereomer. 


\section{Synthetic Procedures for (+)-Rubellin C (1)}
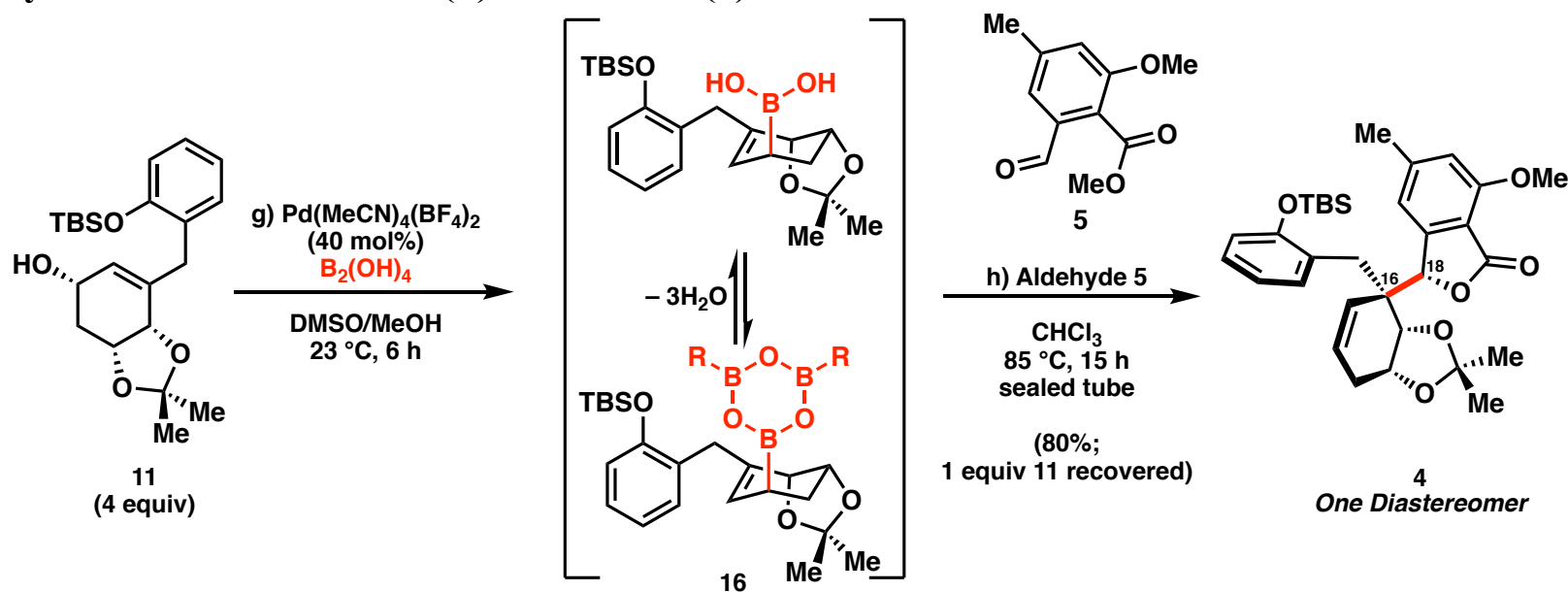

Compound 4: Allylic alcohol 11 (2.42 g, $6.20 \mathrm{mmol}$, 4 equiv) was transferred to a flask as a solution in $\mathrm{CH}_{2} \mathrm{Cl}_{2}$, which was concentrated in vacuo on a rotary evaporator and then on a Schlenk line overnight. After blanketing with argon, degassed DMSO $(8.0 \mathrm{~mL})$ and $\mathrm{MeOH}(1.5 \mathrm{~mL})$ were added to the flask. Once the starting material had dissolved, $\mathrm{Pd}(\mathrm{MeCN})_{4}\left(\mathrm{BF}_{4}\right)_{2}(275 \mathrm{mg}, 0.62 \mathrm{mmol}$, $40 \mathrm{~mol} \%$ ) was added, followed by bisboronic acid $\mathrm{B}_{2}(\mathrm{OH})_{4}(667 \mathrm{mg}, 7.44 \mathrm{mmol}, 4.8$ equiv). The mixture was placed in a room temperature water bath to moderate an initial exotherm, and the mixture was stirred under argon for 6 hours. At this time, the reaction was allowed to settle for 12 hours. The mixture of boronic acid $\mathbf{1 6}$ was transferred by syringe and needle into an argonpurged pear flask, and all further transfers were carried out by syringe and needle into argon-filled vessels to avoid oxygen. Degassed $\mathrm{CHCl}_{3}(19 \mathrm{~mL})$ and a brine/water $(1: 1)$ solution $(19 \mathrm{~mL})$ were added to the mixture under inert atmosphere. The organic layer was washed 3 more times with the degassed water/brine solution ( $19 \mathrm{~mL} \times 3)$, and then transferred into another flask under argon to which had been added $\mathrm{Na}_{2} \mathrm{SO}_{4}$. After 1 hour, the organics were removed from the $\mathrm{Na}_{2} \mathrm{SO}_{4}$ and transferred to a dry microwave vial pre-charged with aldehyde $\mathbf{5}(260 \mathrm{mg}, 1.24 \mathrm{mmol})$ The mixture was submerged into an $85^{\circ} \mathrm{C}$ oil bath and stirred overnight. At this time, the microwave vial was opened to air, and methanol was added. The mixture was transferred to a flask and concentrated on a rotary evaporator, followed by flash column chromatography $(30 \%$ EtOAc/hexanes) to furnish the allylation product 4 as a white foam $(673 \mathrm{mg}, 80 \%)$ as well as starting material allylic alcohol 11 (680 mg, $1.74 \mathrm{mmol}, 1.1$ equiv).

TLC (3:1 Hexanes:EtOAc): $\mathrm{R}_{f} 0.11$ (UV)

${ }^{1} \mathbf{H}$ NMR (400 MHz, $\left.\mathbf{C}_{6} \mathbf{D}_{6}\right): \delta 7.36(\mathrm{dd}, J=7.6,1.7 \mathrm{~Hz}, 1 \mathrm{H}), 6.95-6.86(\mathrm{~m}, 1 \mathrm{H}), 6.76-6.68(\mathrm{~m}$, 2H), $6.64(\mathrm{~s}, 1 \mathrm{H}), 6.19(\mathrm{~s}, 1 \mathrm{H}), 6.10-6.03(\mathrm{~m}, 1 \mathrm{H}), 5.71(\mathrm{ddd}, J=10.1,5.4,3.2 \mathrm{~Hz}, 1 \mathrm{H}), 5.07(\mathrm{~s}$, $1 \mathrm{H}), 4.67(\mathrm{~d}, J=5.8 \mathrm{~Hz}, 1 \mathrm{H}), 4.39(\mathrm{td}, J=6.9,2.8 \mathrm{~Hz}, 1 \mathrm{H}), 3.53(\mathrm{~d}, J=14.4 \mathrm{~Hz}, 1 \mathrm{H}), 3.36(\mathrm{~s}$, $3 \mathrm{H}$ ), 3.13 (d, $J=14.4 \mathrm{~Hz}, 1 \mathrm{H}$ ), 2.16 (dddd, $J=18.2,5.6,2.9,1.3 \mathrm{~Hz}, 1 \mathrm{H}$ ), 2.05 (ddt, $J=18.2,7.2$, $3.0 \mathrm{~Hz}, 1 \mathrm{H}), 1.93$ (s, 3H), 1.42 (s, 3H), 1.24 (s, 3H), 1.03 (s, 10H), 0.15 (s, 3H), $0.14(\mathrm{~s}, 3 \mathrm{H})$.

${ }^{13} \mathbf{C}$ NMR (101 MHz, $\left.\mathbf{C}_{6} \mathbf{D}_{6}\right): \delta 166.8,158.8,154.8,150.9,146.1,132.9,129.6,128.8,128.2,127.9$, $127.3,120.9,119.4,116.4,113.9,112.0,107.7,80.8,77.4,72.4,55.3,46.9,31.5,30.3,27.5,26.3$, 26.3, 25.2, 22.1, 18.7, -3.7, -4.0.

FTIR (ReactIR): 1760, 1606, 1491, 1241, 1045.

HRMS (ESI) m/z: $[\mathrm{M}+\mathrm{H}]^{+}$calc. for $\mathrm{C}_{32} \mathrm{H}_{43} \mathrm{O}_{6} \mathrm{Si}$ 551.2823; found 551.2841. $[\alpha]_{\mathbf{D}}^{25}=-26.6^{\circ}(\mathrm{c}=0.9, \mathrm{MeOH})$. 


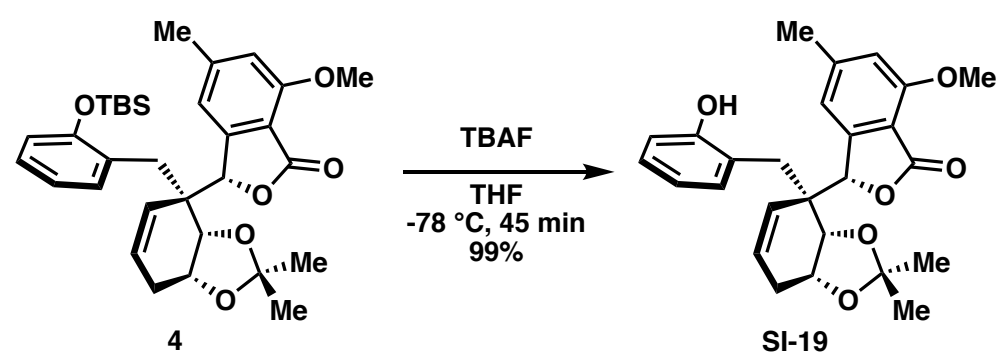

Compound SI-19: A flask was charged with TBS-protected phenol $4(388 \mathrm{mg}, 0.70 \mathrm{mmol})$ and THF $(7.0 \mathrm{~mL}, 0.1 \mathrm{M})$ then cooled to $-78{ }^{\circ} \mathrm{C}$. Tetrabutylammonium fluoride $(1 \mathrm{M}$ in THF, $770 \mu \mathrm{L}$, $0.77 \mathrm{mmol}, 1.1$ equiv) was added dropwise to the clear solution to give a yellow mixture. The mixture was stirred at $-78{ }^{\circ} \mathrm{C}$ for 45 minutes, then quenched by the addition of a 1:1 solution of water and aqueous sat. $\mathrm{NaHCO}_{3}$. The mixture was extracted with EtOAc $(200 \mathrm{~mL})$, washed with water $(\mathrm{x} 3)$ and brine, then dried over $\mathrm{Na}_{2} \mathrm{SO}_{4}$, filtered, and concentrated. The crude product was purified by flash column chromatography ( $40 \%$ EtOAc/hexanes) to give free phenol SI-19 as a white foam (307 mg, 99\%).

TLC (1:1 Hexanes:EtOAc): $\mathrm{R}_{f} 0.36\left(\mathrm{UV}, \mathrm{KMnO}_{4}\right)$

${ }^{1} \mathrm{H}$ NMR (400 MHz, CDCl $): \delta 7.70(\mathrm{~s}, 1 \mathrm{H}), 7.06(\mathrm{t}, J=7.7 \mathrm{~Hz}, 1 \mathrm{H}), 6.83(\mathrm{~s}, 1 \mathrm{H}), 6.80(\mathrm{~d}, J=$ $8.1 \mathrm{~Hz}, 1 \mathrm{H}), 6.72(\mathrm{~s}, 1 \mathrm{H}), 6.52(\mathrm{t}, J=7.4 \mathrm{~Hz}, 1 \mathrm{H}), 6.02(\mathrm{td}, J=6.6,3.1 \mathrm{~Hz}, 1 \mathrm{H}), 5.73(\mathrm{~s}, 1 \mathrm{H}), 5.47$ $(\mathrm{d}, J=10.1 \mathrm{~Hz}, 1 \mathrm{H}), 5.22(\mathrm{~s}, 1 \mathrm{H}), 4.94(\mathrm{~d}, J=6.6 \mathrm{~Hz}, 1 \mathrm{H}), 4.73(\mathrm{t}, J=6.6 \mathrm{~Hz}, 1 \mathrm{H}), 4.04(\mathrm{~s}, 3 \mathrm{H})$, $2.98(\mathrm{~d}, J=15.6 \mathrm{~Hz}, 1 \mathrm{H}), 2.40(\mathrm{~s}, 3 \mathrm{H}), 2.38-2.27(\mathrm{~m}, 2 \mathrm{H}), 1.49(\mathrm{~s}, 3 \mathrm{H}), 1.45(\mathrm{~s}, 3 \mathrm{H})$.

${ }^{13}$ C NMR (101 MHz, CDCl $\left._{3}\right): \delta 168.2,158.7,156.4,149.7,147.9,132.0,129.2,128.6,127.3$, $122.4,119.4,116.6,116.4,112.9,112.4,108.3,80.0,78.8,71.8,56.1,44.6,31.8,29.7,26.3,24.9$, 22.6.

FTIR (ReactIR): 1760, 1607, 1492, 1242, 1048, 921.

HRMS (ESI) m/z: $[\mathrm{M}+\mathrm{H}]^{+}$calc. for $\mathrm{C}_{26} \mathrm{H}_{29} \mathrm{O}_{6}$ 437.1959; found 437.1969. $[\alpha]_{\mathbf{D}}^{25}=-14.0^{\circ}\left(\mathrm{c}=2.6, \mathrm{CHCl}_{3}\right)$.

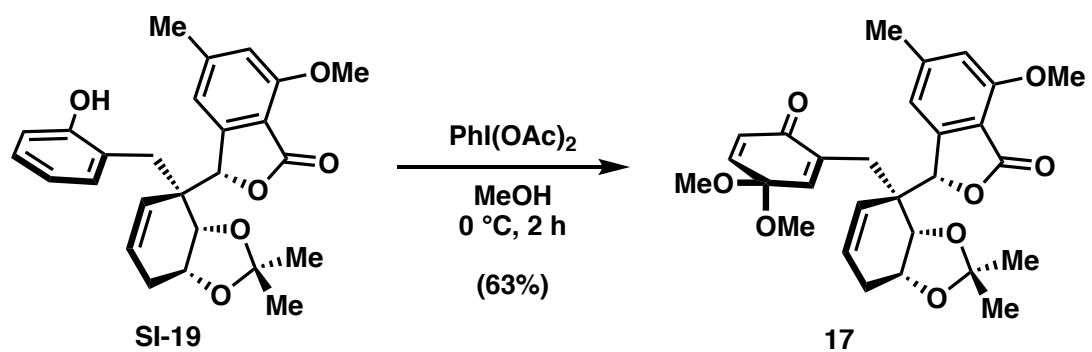

Compound 17: A flask was charged with free phenol SI-19 (306 $\mathrm{mg}, 0.70 \mathrm{mmol})$ and methanol $(14 \mathrm{~mL}, 0.05 \mathrm{M})$ then cooled to $0{ }^{\circ} \mathrm{C}$. (Diacetoxyiodo)benzene (676 mg, $2.1 \mathrm{mmol}, 3$ equiv) was added in one portion, and the mixture was vigorously stirred at $0{ }^{\circ} \mathrm{C}$. After $1 \mathrm{~h}$, the reaction was quenched by the addition of aqueous sat. $\mathrm{NaHCO}_{3}$. Methanol was removed on a rotary evaporator, and the mixture was extracted with EtOAc $(100 \mathrm{~mL})$. The organics were washed with aqueous sat. $\mathrm{NaHCO}_{3}$, aqueous sat. $\mathrm{Na}_{2} \mathrm{~S}_{2} \mathrm{O}_{8}$, and brine. The organics were dried on $\mathrm{Na}_{2} \mathrm{SO}_{4}$, filtered, and concentrated. The crude product was immediately purified by flash column chromatography ( $1 \%$ triethylamine, $45 \%$ EtOAc/hexanes) to give a white foam as the title $p$-quinone monoketal 17 (219 $\mathrm{mg}, 63 \%)$. 
TLC (1:1 Hexanes:EtOAc): $\mathrm{R}_{f} 0.18\left(\mathrm{UV}, \mathrm{KMnO}_{4}\right)$.

${ }^{1} \mathbf{H}$ NMR (400 MHz, $\left.\mathbf{C}_{6} \mathbf{D}_{6}\right) \delta 7.01(\mathrm{~s}, 1 \mathrm{H}), 6.87(\mathrm{~d}, J=3.2 \mathrm{~Hz}, 1 \mathrm{H}), 6.45-6.36(\mathrm{~m}, 2 \mathrm{H}), 6.20(\mathrm{~d}$, $J=10.3 \mathrm{~Hz}, 1 \mathrm{H}), 5.84(\mathrm{ddt}, J=10.0,2.4,1.3 \mathrm{~Hz}, 1 \mathrm{H}), 5.80-5.70(\mathrm{~m}, 1 \mathrm{H}), 4.96(\mathrm{~s}, 1 \mathrm{H}), 4.78(\mathrm{~d}$, $J=6.4 \mathrm{~Hz}, 1 \mathrm{H}), 4.42(\mathrm{td}, J=6.9,2.9 \mathrm{~Hz}, 1 \mathrm{H}), 3.49(\mathrm{~s}, 3 \mathrm{H}), 3.28(\mathrm{~s}, 3 \mathrm{H}), 3.19(\mathrm{~s}, 3 \mathrm{H}), 2.96(\mathrm{~d}, J=$ $14.0 \mathrm{~Hz}, 1 \mathrm{H}), 2.65(\mathrm{~d}, J=13.8 \mathrm{~Hz}, 1 \mathrm{H}), 2.28-2.18(\mathrm{~m}, 4 \mathrm{H}), 2.19(\mathrm{~s}, 4 \mathrm{H}), 2.19-2.07(\mathrm{~m}, 3 \mathrm{H})$, $1.43(\mathrm{~s}, 3 \mathrm{H}), 1.33(\mathrm{~s}, 3 \mathrm{H})$.

${ }^{13} \mathbf{C}$ NMR (101 MHz, $\left.\mathbf{C}_{6} \mathbf{D}_{\mathbf{6}}\right): \delta 185.0,159.0,150.4,146.5,142.4,141.7,137.5,130.6,129.9,128.2$, 128.0, 116.6, 114.0, 112.4, 108.1, 93.8, 80.8, 77.1, 72.1, 55.4, 50.5, 50.1, 46.2, 30.4, 29.4, 27.2, 25.1, 22.3.

FTIR (ReactIR): 2990, 2364, 1700, 1652, 705.

HRMS (ESI) m/z: $[\mathrm{M}+\mathrm{H}]^{+}$calc. for $\mathrm{C}_{28} \mathrm{H}_{33} \mathrm{O}_{8}$ 497.2170; found 497.2165.

$[\alpha]_{\mathbf{D}}^{25}=-38.9^{\circ}(\mathrm{c}=1.3, \mathrm{MeOH})$.

Table S2. Optimization of Hauser Reaction

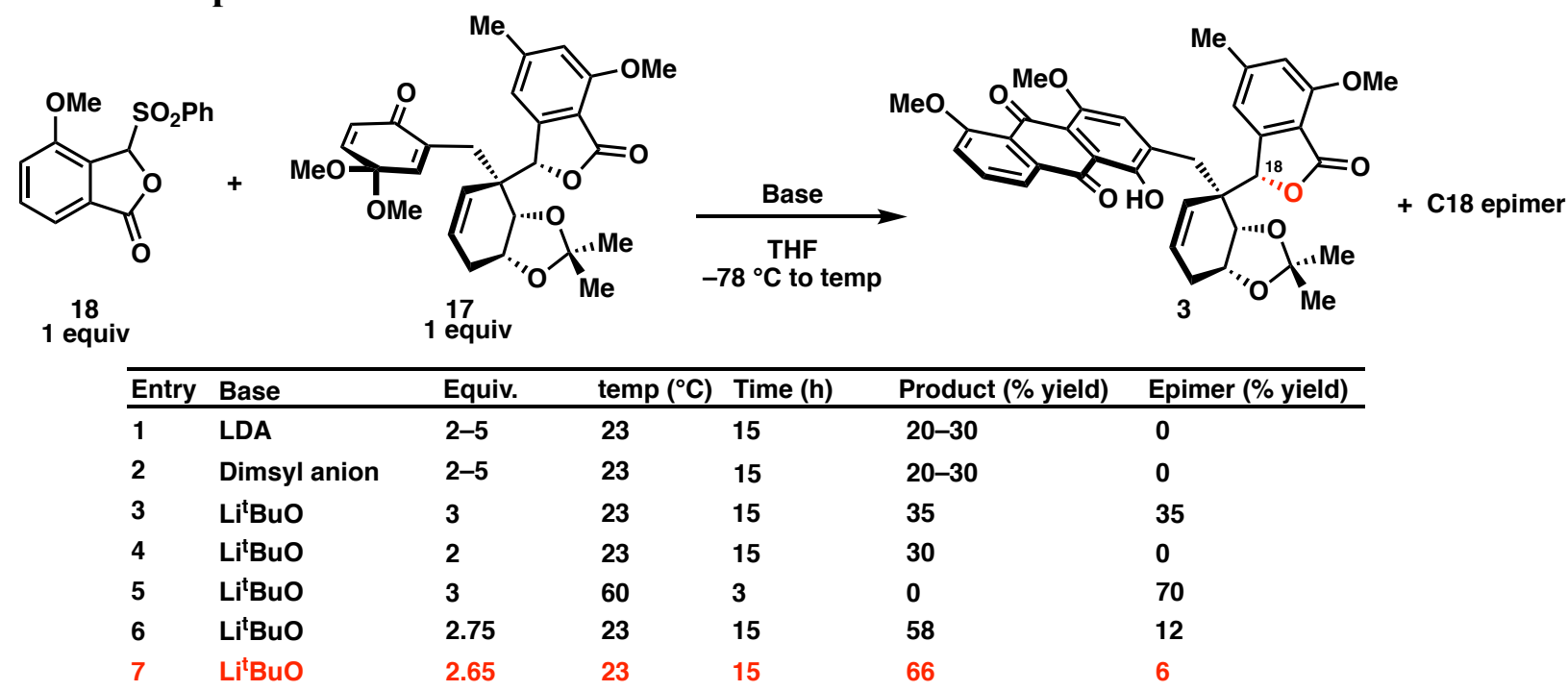

A flame-dried $4 \mathrm{~mL}$ vial was charged with solvent and base and cooled to $-78^{\circ} \mathrm{C}$. Sulphone 18 was added as a solid, and the mixture was stirred at $-78^{\circ} \mathrm{C}$ for 15 minutes. At this time, $p$-quinone monoketal 17 was added in THF $(0.33 \mathrm{M})$ and the reaction was brought slowly to the given temperature. After 15 hours, the purple mixture was cooled to $0{ }^{\circ} \mathrm{C}$ and quenched with the addition of water. The mixture was transferred into a separatory funnel with EtOAc and the layers were separated. The aqueous layer was acidified with $1 \mathrm{~N} \mathrm{HCl}$ to $\mathrm{pH}$ of 4-5, and then extracted with EtOAc. The red organic layer was dried over $\mathrm{Na}_{2} \mathrm{SO}_{4}$, filtered, and concentrated to give a red residue. The residue was purified by flash column chromatography (75\% EtOAc/hexanes) to give the desired anthraquinone 3 as a red foam and the undesired epimer 19 (full characterization data and a specific example vide infra). 

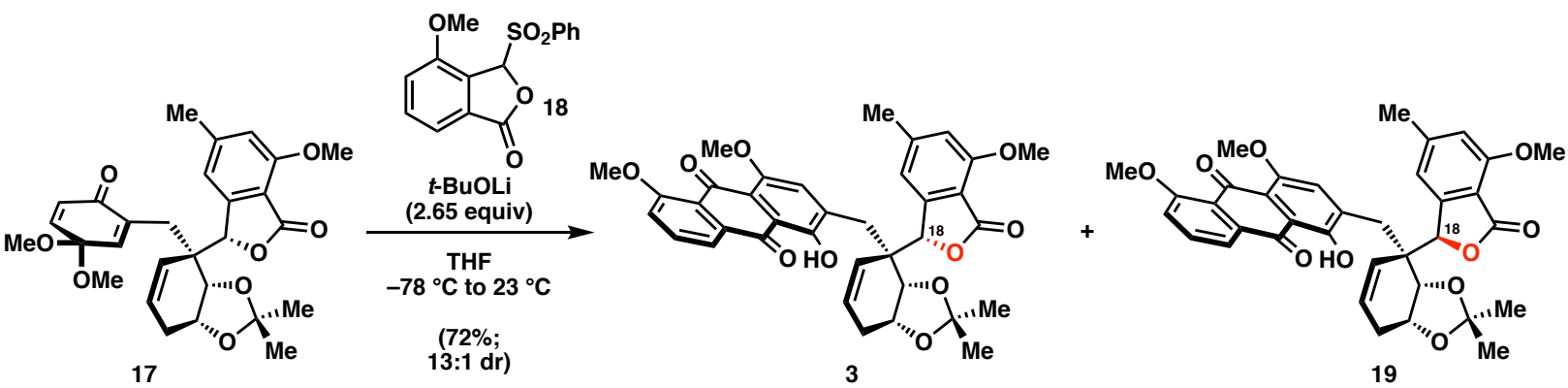

Compounds 3 and 19: A flame-dried $25 \mathrm{~mL}$ flask was charged with $t$-BuOLi (1M in THF, 1.60 $\mathrm{mL}, 2.65$ equiv) and cooled to $-78{ }^{\circ} \mathrm{C}$. Sulphone $18(181 \mathrm{mg}, 0.60 \mathrm{mmol}, 1$ equiv) was added as a solid in one portion (note: if not added as a solid as this stage, reaction yield and d.r. would significantly decrease) to give an orange-yellow mixture, which was stirred at $-78{ }^{\circ} \mathrm{C}$ for 15 minutes. At this time, $p$-quinone monoketal $17(297 \mathrm{mg}, 0.60 \mathrm{mmol})$ was added in THF $(1.80 \mathrm{~mL}$, $0.33 \mathrm{M}$ ) dropwise to the mixture. The resulting mixture was stirred at $-78^{\circ} \mathrm{C}$ and allowed to slowly warm to room temperature. The color changed from orange yellow to a deep purple, indicating formation of the deprotonated anthraquinone. After 15 hours, the purple mixture was cooled to 0 ${ }^{\circ} \mathrm{C}$ and quenched with the addition of water. The mixture was transferred into a separatory funnel with EtOAc $(40 \mathrm{~mL})$ and the layers were separated. The aqueous layer was acidified with $1 \mathrm{~N} \mathrm{HCl}$ to $\mathrm{pH}$ of 4-5, and then extracted with EtOAc (100 $\mathrm{mL}$ total). The red organic layer was dried over $\mathrm{Na}_{2} \mathrm{SO}_{4}$, filtered, and concentrated to give a red residue. The residue was purified by flash column chromatography ( $75 \%$ EtOAc/hexanes) to give the desired anthraquinone 3 (250 $\mathrm{mg}, 66 \%$ ) as a red foam and the undesired epimer $19(21 \mathrm{mg}, 6 \%$; total 72\% yield of anthraquinones) as a red solid, whose crystal structure was confirmed by X-ray crystallography. If epimer 19 was desired, the reaction could be simply heated to reflux for 3 hours for full conversion, or 3 could be heated after isolation with $>1$ equiv $t$-BuOLi.

\section{Desired anthraquinone 3:}

TLC (EtOAc): $\mathrm{R}_{f} 0.35$ (UV, visible red spot).

${ }^{1}$ H NMR (400-MHz, CDCl $): \delta 12.90(\mathrm{~s}, 1 \mathrm{H}), 7.85(\mathrm{~d}, J=1.0 \mathrm{~Hz}, 1 \mathrm{H}), 7.64(\mathrm{t}, J=8.1 \mathrm{~Hz}, 1 \mathrm{H})$, $7.36-7.28(\mathrm{~m}, 2 \mathrm{H}), 6.94(\mathrm{~s}, 1 \mathrm{H}), 6.58(\mathrm{~s}, 1 \mathrm{H}), 6.10-5.99(\mathrm{~m}, 2 \mathrm{H}), 5.23(\mathrm{~s}, 1 \mathrm{H}), 4.73(\mathrm{~d}, J=6.6$ $\mathrm{Hz}, 1 \mathrm{H}), 4.63(\mathrm{td}, J=6.9,2.7 \mathrm{~Hz}, 1 \mathrm{H}), 4.00(\mathrm{~s}, 3 \mathrm{H}), 3.93(\mathrm{~s}, 3 \mathrm{H}), 3.90(\mathrm{~s}, 3 \mathrm{H}), 3.08(\mathrm{~d}, J=14.2$ $\mathrm{Hz}, 1 \mathrm{H}), 3.01(\mathrm{~d}, J=14.2 \mathrm{~Hz}, 1 \mathrm{H}), 2.55-2.40(\mathrm{~m}, 1 \mathrm{H}), 2.35(\mathrm{~s}, 2 \mathrm{H}), 2.32$ (dd, $J=4.8,2.7 \mathrm{~Hz}$, $1 \mathrm{H}), 1.40(\mathrm{~s}, 3 \mathrm{H}), 1.34(\mathrm{~s}, 3 \mathrm{H})$.

${ }^{13}$ C NMR (101 MHz, $\left.\mathbf{C D C l}_{3}\right): \delta 189.1,182.0,168.3,159.8,158.2,155.7,152.3,150.0,147.3$, $134.8,134.7,133.9,129.4,127.9,127.8,124.0,120.5,118.7,118.6,116.8,114.7,112.5,111.8$, $108.0,81.0,77.8,72.1,57.2,56.7,55.9,46.5,30.9,29.8,27.1,25.2,22.6$.

FTIR (ReactIR): 1761, 1670, 1607, 1237, 1048.

HRMS (ESI) m/z: $[\mathrm{M}+\mathrm{H}]^{+}$calc. for $\mathrm{C}_{36} \mathrm{H}_{35} \mathrm{O}_{10} 627.2225$, found 627.2254 .

$[\alpha]_{\mathbf{D}}^{25}=-163^{\circ}(\mathrm{c}=0.8, \mathrm{MeOH})$.

\section{Undesired epimer anthraquinone 19:}

TLC (EtOAc): $\mathrm{R}_{f} 0.50$ (UV, visible red spot).

${ }^{1}$ H NMR (400 MHz, CDCl $): \delta 13.34(\mathrm{~s}, 1 \mathrm{H}), 7.91-7.85(\mathrm{~m}, 2 \mathrm{H}), 7.66(\mathrm{t}, J=8.1 \mathrm{~Hz}, 1 \mathrm{H}), 7.33$ $(\mathrm{dd}, J=8.5,1.1 \mathrm{~Hz}, 1 \mathrm{H}), 7.24(\mathrm{~s}, 1 \mathrm{H}), 6.73(\mathrm{~s}, 1 \mathrm{H}), 5.74(\mathrm{dt}, J=10.1,4.1 \mathrm{~Hz}, 1 \mathrm{H}), 5.35(\mathrm{~s}, 1 \mathrm{H})$, $5.19(\mathrm{dd}, J=10.1,1.6 \mathrm{~Hz}, 1 \mathrm{H}), 4.18$ (ddd, $J=7.7,6.0,3.8 \mathrm{~Hz}, 1 \mathrm{H}), 4.08(\mathrm{dd}, J=6.0,1.3 \mathrm{~Hz}, 1 \mathrm{H})$, 4.01 (s, 3H), 3.97 (s, 3H), 3.96 (s, 3H), 3.58 (d, $J=13.8 \mathrm{~Hz}, 1 \mathrm{H}), 3.20$ (d, $J=13.9 \mathrm{~Hz}, 1 \mathrm{H}), 2.46$ 
(s, 4H), $2.12(\mathrm{dtd}, J=18.5,4.3,2.0 \mathrm{~Hz}, 1 \mathrm{H}), 1.46(\mathrm{~s}, 3 \mathrm{H}), 1.34(\mathrm{~s}, 3 \mathrm{H})$.

${ }^{13}$ C NMR (101 MHz, $\left.\mathbf{C D C l}_{3}\right): \delta 189.5,182.1,168.2,159.8,158.3,156.3,152.7,150.5,147.5$, $134.6,134.1,133.8,128.7,128.2,126.7,123.9,121.1,118.9,118.7,116.8,115.3,112.0,112.0$, $107.4,82.2,75.4,72.5,57.5,56.7,56.0,46.9,33.1,30.2,27.8,26.1,22.9$.

FTIR (ReactIR): 1761, 1670, 1607, 1236, 1046.

HRMS (ESI) m/z: $[\mathrm{M}+\mathrm{H}]^{+}$calc. for $\mathrm{C}_{36} \mathrm{H}_{35} \mathrm{O}_{10} 627.2225$; found 627.2252. $[\alpha]_{\mathrm{D}}^{25}=-1443^{\circ}\left(\mathrm{c}=0.7, \mathrm{CHCl}_{3}\right)$.

Table S3. Optimization of Triflation

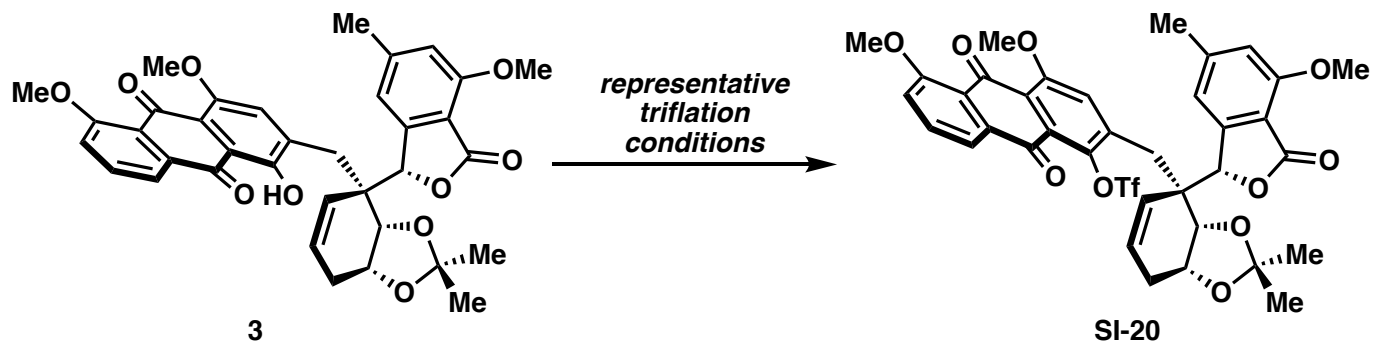

\begin{tabular}{|c|c|c|c|c|c|c|}
\hline Entry & Solvent & Base (equiv) & Triflating Reagent & temp $\left({ }^{\circ} \mathrm{C}\right)$ & Time (h) & SI-20 (\% yield) \\
\hline 1 & $\mathrm{CH}_{2} \mathrm{Cl}_{2}$ & Pyr (20) & $\mathrm{PhNTf}_{2}$ & $0-40$ & 15 & 0 \\
\hline 2 & $\mathrm{CH}_{2} \mathrm{Cl}_{2}$ & DBU (10) & $\mathrm{PhNTf}_{2}$ & $0-40$ & 15 & 0 \\
\hline 3 & THF & LDA (3) & $\mathrm{PhNTf}_{2}$ & $-78-23$ & 15 & 0 \\
\hline 4 & $\mathrm{CH}_{2} \mathrm{Cl}_{2}$ & DBU (20) & Comins' & $0-23$ & 15 & 0 \\
\hline 5 & $\mathrm{CH}_{2} \mathrm{Cl}_{2}$ & Pyr (20) & Comins' & $0-23$ & 15 & 0 \\
\hline 6 & $\mathrm{CH}_{2} \mathrm{Cl}_{2}$ & Pyr (3) & $\mathrm{Tf}_{2} \mathrm{O}$ & $-78-0$ & 2 & 36 \\
\hline 7 & THF & $\mathrm{NaH}(10)$ & $\mathrm{Tf}_{2} \mathrm{O}$ & -78 & 2 & $0^{a}$ \\
\hline 8 & $\mathrm{CH}_{2} \mathrm{Cl}_{2}$ & $\mathrm{NaH}(10)$ & $\mathrm{Tf}_{2} \mathrm{O}$ & 0 & 5 & 50 \\
\hline 9 & DME & $\mathrm{NaH}(10)$ & $\mathrm{Tf}_{2} \mathrm{O}$ & 0 & 5 & 50 ; mixture of $\mathrm{C} 18$ isomers \\
\hline 10 & $\mathrm{CH}_{2} \mathrm{Cl}_{2}$ & $\mathrm{NaH}(5)$ & $\mathrm{Tf}_{2} \mathrm{O}$ & 0 & 5 & 0 ; full decomposition \\
\hline 11 & $\mathrm{CH}_{2} \mathrm{Cl}_{2}$ & $\mathrm{NaH}(20)$ & $\mathrm{Tf}_{2} \mathrm{O}$ & 0 & 5 & $72 \%$ \\
\hline 12 & $\mathrm{CH}_{2} \mathrm{Cl}_{2}$ & NaH (20) \& Pyr (3) & $\mathrm{Tf}_{2} \mathrm{O}$ & 0 & 5 & $73 \% \%^{b}$ \\
\hline
\end{tabular}

General procedure for optimization of triflation of anthraquinone 3: A dry vial was charged with base and solvent. Anthraquinone $3(0.1 \mathrm{mmol}$ to $0.01 \mathrm{mmol})$ was added in solvent dropwise. Purple color denoted deprotonation of the red anthraquinone to its corresponding phenol. The triflating reagent ( 3 equiv) was added afterwards. Reactions were monitored by ${ }^{1} \mathrm{H}-\mathrm{NMR}$, as the starting material and triflate co-spot as an orange mixture on TLC and were not suitably separable, however ${ }^{1} \mathrm{H}$ and ${ }^{19} \mathrm{~F}$ NMR values were obtainable. a) The polymer of THF produced by triflic anhydride $\left(\mathrm{Tf}_{2} \mathrm{O}\right)$ decomposes the mixture of product and starting material quickly during purification. b) The deprotonation of anthraquinone $\mathbf{3}$ with sodium hydride is very slow on larger scales $(>0.1 \mathrm{mmol})$. The addition of pyridine after $\mathrm{Tf}_{2} \mathrm{O}$ increased conversion and rate at 0.23 mmol scale. SI-20 ${ }^{1} \mathbf{H}$ NMR: (400 $\left.\mathbf{M H z}, \mathbf{C D C l}_{3}\right): \delta 7.76-7.69(\mathrm{~m}, 2 \mathrm{H}), 7.66(\mathrm{t}, J=8.0 \mathrm{~Hz}, 1 \mathrm{H})$, $7.29(\mathrm{dd}, J=8.5,1.1 \mathrm{~Hz}, 1 \mathrm{H}), 6.74(\mathrm{~s}, 1 \mathrm{H}), 6.73(\mathrm{~s}, 1 \mathrm{H}), 6.03(\mathrm{ddd}, J=9.9,5.5,3.0 \mathrm{~Hz}, 1 \mathrm{H}), 5.34$ $(\mathrm{d}, J=10.7 \mathrm{~Hz}, 1 \mathrm{H}), 5.05(\mathrm{~s}, 1 \mathrm{H}), 4.00(\mathrm{~s}, 3 \mathrm{H}), 4.00(\mathrm{~s}, 3 \mathrm{H}), 3.98(\mathrm{~s}, 3 \mathrm{H}), 3.73(\mathrm{~d}, J=5.9 \mathrm{~Hz}, 1 \mathrm{H})$, $3.58(\mathrm{q}, J=6.6 \mathrm{~Hz}, 1 \mathrm{H}), 3.50-3.40(\mathrm{~m}, 2 \mathrm{H}), 2.44(\mathrm{dd}, J=12.2,5.6 \mathrm{~Hz}, 1 \mathrm{H}), 2.39(\mathrm{~s}, 3 \mathrm{H}), 2.24-$ $2.16(\mathrm{~m}, 1 \mathrm{H}), 1.44(\mathrm{~s}, 3 \mathrm{H}), 1.43(\mathrm{~s}, 2 \mathrm{H}) .{ }^{19} \mathbf{F}$ NMR (400 $\left.\mathbf{M H z}, \mathbf{C D C l}_{3}\right): \delta-73.8$ TLC (EtOAc): $\mathrm{R}_{f}$ 0.44 (UV, visible yellow spot). 


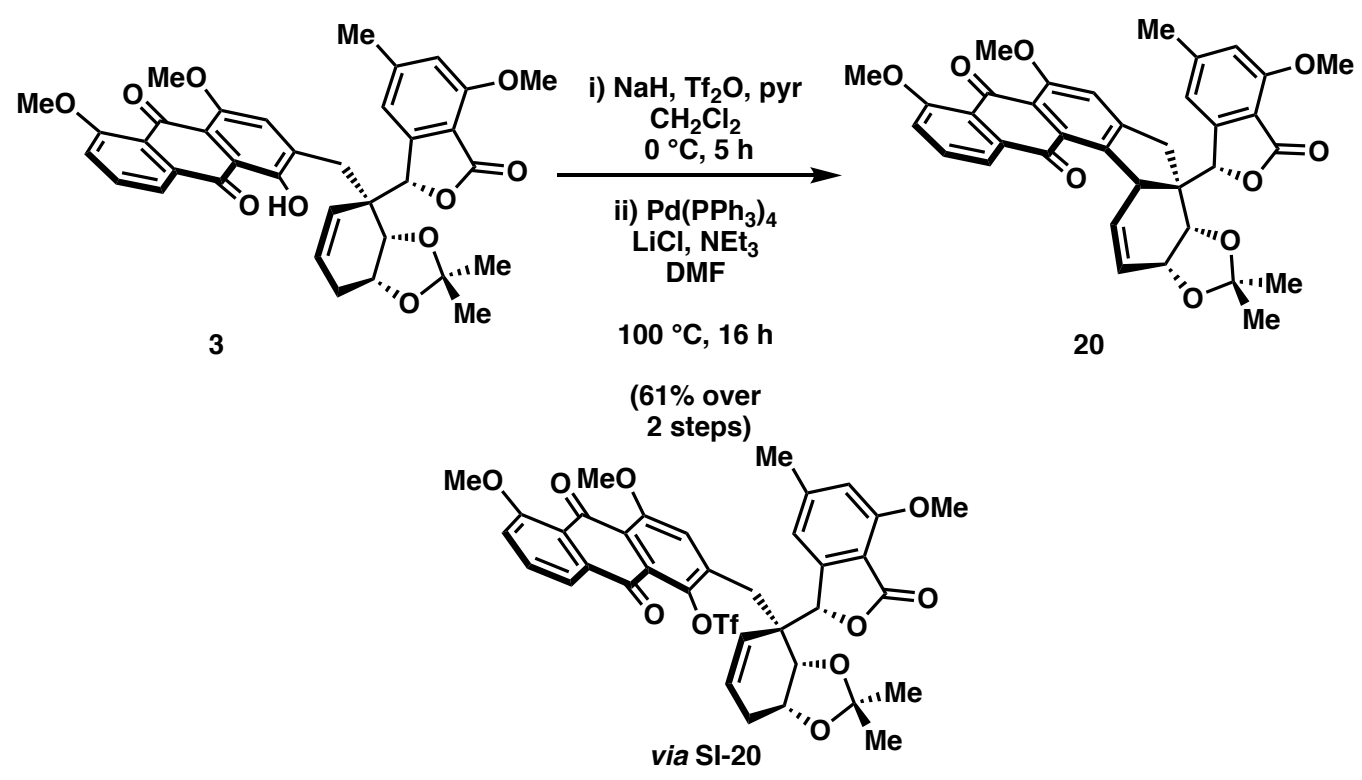

Compound 20: A flame-dried flask was charged with sodium hydride (60\% in mineral oil) (184 $\mathrm{mg}, 4.6 \mathrm{mmol}, 20$ equiv) and purged with argon. The sodium hydride was washed with hexanes $(3 \mathrm{x}, 10 \mathrm{~mL})$ and dried under vacuum to remove residual solvent for 15 minutes. After blanketing with argon, $\mathrm{CH}_{2} \mathrm{Cl}_{2}(5.75 \mathrm{~mL})$ was added, and the mixture was cooled to $0{ }^{\circ} \mathrm{C}$. Anthraquinone 3 (143 mg, $0.23 \mathrm{mmol}$ ) was added in $\mathrm{CH}_{2} \mathrm{Cl}_{2}(5.75 \mathrm{~mL})$ dropwise to the sodium hydride mixture to give a purple mixture. The reaction was stirred at $0{ }^{\circ} \mathrm{C}$ for 4 hours. At this time, trifluoromethanesulfonic anhydride (either from an ampule or freshly distilled from $\left.\mathrm{PO}_{5}\right)(116 \mu \mathrm{L}$, $0.69 \mathrm{mmol}, 3$ equiv) was added dropwise to the reaction, followed by pyridine $(55 \mu \mathrm{L}, 0.69 \mathrm{mmol}$, 3 equiv) to give an orange mixture. The mixture was stirred at $0{ }^{\circ} \mathrm{C}$ for 1 hour and quenched by the addition of aqueous sat. $\mathrm{NaHCO}_{3}$ solution. The mixture was extracted with $\mathrm{CH}_{2} \mathrm{Cl}_{2}(50 \mathrm{~mL})$ and the organics were washed with sat. $\mathrm{NaHCO}_{3}$ solution and brine. The organics were dried over $\mathrm{Na}_{2} \mathrm{SO}_{4}$, filtered, and evaporated to yield a mixture of the title triflate and starting unprotected anthraquinone. The triflate was purified by flash column chromatography ( $75 \% \mathrm{EtOAc/hexanes).}$ The yellow/orange band was collected to give an inseparable mixture of free anthraquinone and triflate SI-20. A flame-dried $100 \mathrm{~mL}$ flask was charged with $\mathrm{Pd}\left(\mathrm{PPh}_{3}\right)_{4}(133 \mathrm{mg}, 0.115 \mathrm{mmol}, 50$ mol\%) and oven-dried $\mathrm{LiCl}(146 \mathrm{mg}, 3.45 \mathrm{mmol}, 15$ equiv) then purged with argon. DMF (26 mL) was added to the solids, then the mixture of triflate and anthraquinone in DMF $(20 \mathrm{~mL})$, then triethylamine ( $478 \mu \mathrm{L}, 3.45 \mathrm{mmol}, 15$ equiv). The mixture was subjected to freeze-pump-thaw procedure (3x). After warming to room temperature, the flask was removed from the Schlenk line and sealed tightly with parafilm and black electrical tape. The mixture was submerged into a 100 ${ }^{\circ} \mathrm{C}$ oil bath and stirred for $15 \mathrm{~h}$. At this time, the flask was cooled to room temperature and treated with brine. The mixture was extracted with EtOAc (total $200 \mathrm{~mL}$ ), and the organics were washed with water (3x) and brine (3x). The organics were dried over $\mathrm{Na}_{2} \mathrm{SO}_{4}$, filtered, and concentrated to a residue. The residue was purified on a Teledyne-ISCO CombiFlash Rf-200 UV-Vis Automated Flash Chromatography System with a RediSep Rf High Performance Gold $15.5 \mathrm{~g}$ HP $\mathrm{C} 18$ column on a $5-100 \% \mathrm{MeCN}$ in $\mathrm{H}_{2} \mathrm{O}$ gradient to give compound $\mathbf{2 0}$ as a yellow solid ( $83 \mathrm{mg}$, $61 \%$ over 2 steps). Analysis of the crude mixture showed one diastereomer.

TLC (EtOAc): $\mathrm{R}_{f} 0.41$ (UV, visible yellow spot).

${ }^{1} \mathbf{H}$ NMR (400 MHz, $\left.\mathbf{C D C l}_{3}\right): \delta 7.77(\mathrm{~d}, J=7.7 \mathrm{~Hz}, 1 \mathrm{H}), 7.63(\mathrm{t}, J=8.0 \mathrm{~Hz}, 1 \mathrm{H}), 7.27(\mathrm{~d}, 1 \mathrm{H}, 7.7$ $\mathrm{Hz}), 7.21(\mathrm{~s}, 1 \mathrm{H}), 6.91(\mathrm{~s}, 1 \mathrm{H}), 6.68(\mathrm{~s}, 1 \mathrm{H}), 5.91-5.79(\mathrm{~m}, 2 \mathrm{H}), 5.06(\mathrm{~s}, 1 \mathrm{H}), 4.80(\mathrm{~d}, J=2.0 \mathrm{~Hz}$, 
$1 \mathrm{H}), 4.63(\mathrm{~d}, J=7.2 \mathrm{~Hz}, 1 \mathrm{H}), 4.29(\mathrm{~d}, J=7.2 \mathrm{~Hz}, 1 \mathrm{H}), 4.00(\mathrm{~s}, 3 \mathrm{H}), 3.99(\mathrm{~s}, 3 \mathrm{H}), 3.94(\mathrm{~s}, 3 \mathrm{H})$, $3.48(\mathrm{~d}, J=17.4 \mathrm{~Hz}, 1 \mathrm{H}), 3.18(\mathrm{~d}, J=17.4 \mathrm{~Hz}, 1 \mathrm{H}), 2.40$ (s, 3H), 1.39 (s, 3H), 1.21 (s, 3H).

${ }^{1} \mathbf{H}$ NMR $\left(400 \mathrm{MHz}, \mathbf{C}_{6} \mathbf{D}_{6}\right): \delta 7.92(\mathrm{dd}, J=7.7,1.0 \mathrm{~Hz}, 1 \mathrm{H}), 7.04(\mathrm{t}, J=8.0 \mathrm{~Hz}, 1 \mathrm{H}), 6.76(\mathrm{~s}, 1 \mathrm{H})$, $6.55(\mathrm{~d}, J=8.2 \mathrm{~Hz}, 1 \mathrm{H}), 6.53(\mathrm{~s}, 1 \mathrm{H}), 6.13(\mathrm{~s}, 1 \mathrm{H}), 5.96(\mathrm{dt}, J=10.2,1.9 \mathrm{~Hz}, 1 \mathrm{H}), 5.74$ (ddd, $J=$ $10.1,3.9,2.4 \mathrm{~Hz}, 1 \mathrm{H}), 5.19$ (q, $J=2.3 \mathrm{~Hz}, 1 \mathrm{H}), 4.82(\mathrm{~s}, 1 \mathrm{H}), 4.32$ (d, $J=7.2 \mathrm{~Hz}, 1 \mathrm{H}), 4.22$ (ddt, $J$ $=7.4,3.8,1.8 \mathrm{~Hz}, 1 \mathrm{H}), 3.51(\mathrm{~d}, J=17.2 \mathrm{~Hz}, 1 \mathrm{H}), 3.38(\mathrm{~s}, 3 \mathrm{H}), 3.32(\mathrm{~s}, 3 \mathrm{H}), 3.26(\mathrm{~s}, 3 \mathrm{H}), 3.06(\mathrm{~d}$, $J=17.2 \mathrm{~Hz}, 1 \mathrm{H}), 2.02(\mathrm{~s}, 3 \mathrm{H}), 1.40$ (s, 3H), 1.04 (s, 3H).

${ }^{13}$ C NMR (101 MHz, $\left.\mathbf{C}_{6} \mathbf{D}_{6}\right): \delta$ 185.3, 181.8, 166.9, 159.8, 159.2, 158.6, 151.6, 148.2, 145.4, 137.1, 135.9, 133.3, 130.6, 130.3, 125.5, 125.2, 121.6, 119.0, 117.9, 116.9, 115.2, 113.4, 111.9, 108.4, $81.5,73.3,70.9,56.3,55.9,55.1,53.8,48.8,36.1,26.3,24.7,22.1$.

FTIR (ReactIR): 1760, 1696, 1541, 740, 709.

HRMS (ESI) m/z: $[\mathrm{M}+\mathrm{Na}]^{+}$calculated $\mathrm{C}_{36} \mathrm{H}_{32} \mathrm{O} 9 \mathrm{Na}$ 631.1939, found 631.1945 .

$[\alpha]_{\mathrm{D}}^{25}:+285^{\circ}\left(\mathrm{c}=0.4, \mathrm{CHCl}_{3}\right)$. 
Table S4. Optimization of Demethylation

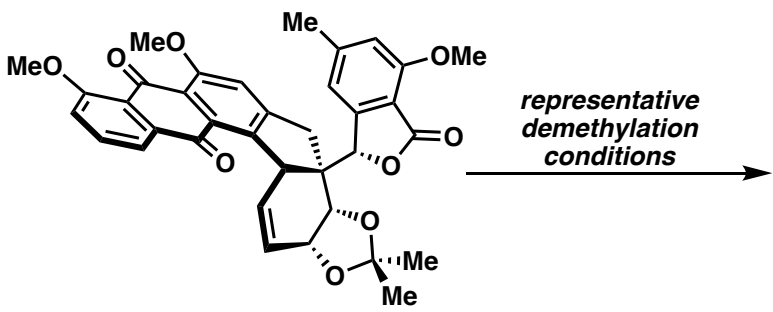

20

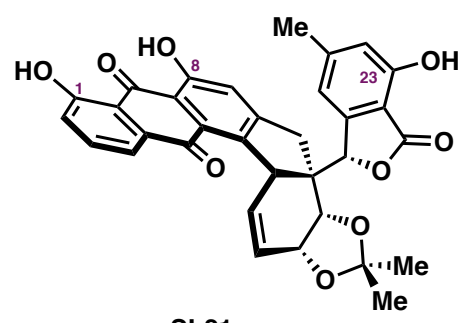

SI-21

\begin{tabular}{|c|c|c|c|c|c|c|}
\hline Entry & Solvent & Reagent (equiv) & Additive (equiv) & temp $\left({ }^{\circ} \mathrm{C}\right)$ & Time (h) & Products Observed \\
\hline 1 & $\mathrm{CH}_{2} \mathrm{Cl}_{2}$ & $\mathrm{BBr}_{3}(10)$ & - & -78 & $1 \mathrm{~h}$ & C23 O-demethylation \\
\hline 2 & $\mathrm{CH}_{2} \mathrm{Cl}_{2}$ & $\mathrm{BBr}_{3}(10)$ & - & $-78-0$ & $2 \mathrm{~h}$ & Decomposition \\
\hline 3 & $\mathrm{CH}_{2} \mathrm{Cl}_{2}$ & $\mathrm{BBr}_{3}(10)$ & - & -78 & $4 \mathrm{~h}$ & C23 O-demethylation; decomposition \\
\hline 4 & $\mathrm{CH}_{2} \mathrm{Cl}_{2}$ & $\mathrm{BBr}_{3}(3)$ & - & -78 & 15 & C23 O-demethylation; 26 \\
\hline 5 & $\mathrm{CH}_{2} \mathrm{Cl}_{2}$ & $\mathrm{BBr}_{3}(10)$ & - & -40 & 1 & C23 O-demethylation; decomposition \\
\hline 6 & $\mathrm{CH}_{2} \mathrm{Cl}_{2}$ & $\mathrm{BBr}_{3}(10)$ & Amylene (11) & -40 & 1 & C23 O-demethylation; decomposition \\
\hline 7 & None & $\mathrm{Pyr} \cdot \mathrm{HCl}(200)$ & - & 200 & 1 & Decomposition \\
\hline 8 & $\mathrm{CH}_{2} \mathrm{Cl}_{2}$ & $\mathrm{BCl}_{3}(10)$ & - & 0 & 24 & C23 O-demethylation; decomposition \\
\hline 9 & $\mathrm{CHCl}_{3}$ & TMSI (4) & - & 0 & 0.5 & C1/8 O-demethylation; decomposition \\
\hline 10 & $\mathrm{CH}_{2} \mathrm{Cl}_{2}$ & $\mathrm{AlCl}_{3}(10)$ & - & 23 & 5 & Mixture of demethylated epimers; iodination \\
\hline 11 & $\mathrm{CH}_{2} \mathrm{Cl}_{2}$ & $\mathrm{AlCl}_{3}(10)$ & EtSH (10) & 0 & 0.25 & C1/8 O-demethylation; decomposition \\
\hline $12^{\mathrm{a}}$ & THF & $\mathrm{Mgl}_{2} \cdot \mathrm{OEt}_{2}(10)$ & - & 50 & 3 & C1/8 O-demethylation; epimerization \\
\hline 13 & PhMe & $\mathrm{Mgl}_{2} \cdot \mathrm{OEt}_{2}(12)$ & - & 100 & 2 & Mixture of SI-21 and C1/8 O-demethylation \\
\hline 14 & PhMe & $\mathrm{Mgl}_{2} \cdot \mathrm{OEt}_{2}(14)$ & - & 100 & 3 & SI-21 \\
\hline
\end{tabular}

General procedure for optimization of demethylation of Heck product 20: Compound 20 (1$5 \mathrm{mg}$ ) was dissolved in solvent $(0.01-0.001 \mathrm{M})$ and cooled to the desired temperature. Demethylating reagent and additive were added, and the reaction was brought to the next desired temperature and monitored by TLC. The reaction was quenched upon formation of new spots and extracted with EtOAc, dried over $\mathrm{Na}_{2} \mathrm{SO}_{4}$, concentrated in vacuo, and analyzed by ${ }^{1} \mathrm{H}-\mathrm{NMR}$. SI$21{ }^{1}$ H NMR (400 MHz, CDCl $): \delta 12.64(\mathrm{~s}, 1 \mathrm{H}), 12.12(\mathrm{~s}, 1 \mathrm{H}), 7.78(\mathrm{~d}, J=7.6 \mathrm{~Hz}, 1 \mathrm{H}), 7.68(\mathrm{t}$, $J=8.0 \mathrm{~Hz}, 1 \mathrm{H}), 7.29(\mathrm{~d}, J=8.4 \mathrm{~Hz}, 1 \mathrm{H}), 7.22(\mathrm{~s}, 1 \mathrm{H}), 6.86(\mathrm{~s}, 1 \mathrm{H}), 6.73(\mathrm{~s}, 1 \mathrm{H}), 5.89(\mathrm{ddd}, J=$ $10.1,3.9,2.5 \mathrm{~Hz}, 1 \mathrm{H}), 5.74(\mathrm{dt}, J=10.1,1.8 \mathrm{~Hz}, 1 \mathrm{H}), 5.21(\mathrm{~s}, 1 \mathrm{H}), 4.72(\mathrm{~d}, J=2.5 \mathrm{~Hz}, 1 \mathrm{H}), 4.70$ $-4.63(\mathrm{~m}, 1 \mathrm{H}), 4.34(\mathrm{~d}, J=7.1 \mathrm{~Hz}, 1 \mathrm{H}), 3.53(\mathrm{~d}, J=17.7 \mathrm{~Hz}, 1 \mathrm{H}), 3.20(\mathrm{~d}, J=17.7 \mathrm{~Hz}, 1 \mathrm{H}), 2.41$ $(\mathrm{s}, 3 \mathrm{H}), 1.44(\mathrm{~s}, 3 \mathrm{H}), 1.28$ (s, 3H). TLC (1:1 Hexanes:EtOAc): $\mathrm{R}_{f} 0.66$ (UV, visible yellow spot). a) Initial experiments with $\mathrm{MgI}_{2} \cdot \mathrm{OEt}_{2}$ were allowed to cool for $30 \mathrm{~min}-1$ hour before quenching. This gave epimerization of the $\mathrm{C} 18$ center as well as iodinated byproducts. Entries 13 and 14 were quenched within 10-15 minutes of removal from the heating oil bath.
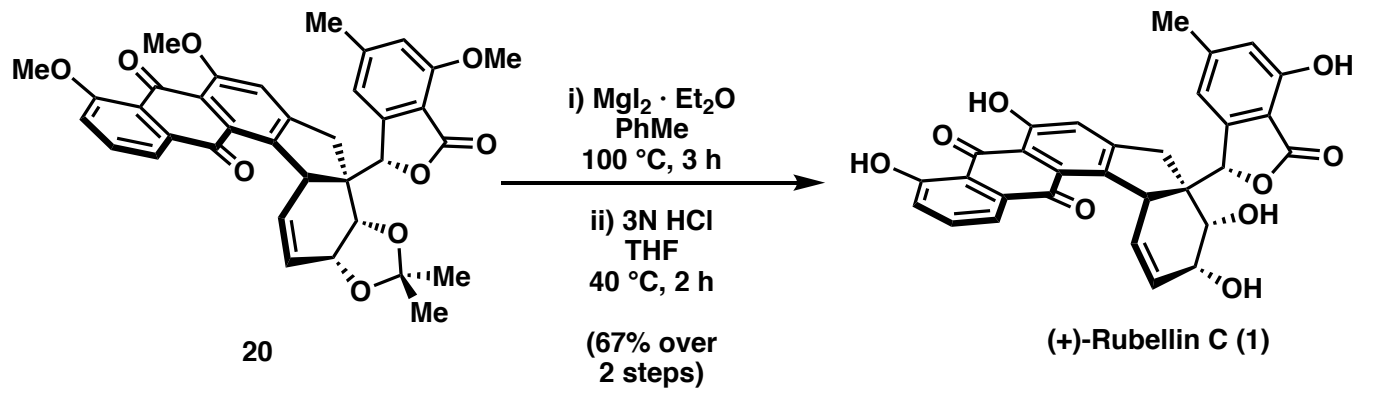

(+)-Rubellin C (1)

(+)-Rubellin C (1): A dry flask was charged with powdered magnesium (52 mg, $2.2 \mathrm{mmol}$ ) and iodine $(278 \mathrm{mg}, 1.1 \mathrm{mmol})$. Dry ether $(10 \mathrm{~mL}, 0.1 \mathrm{M})$ was added, and the flask was covered in 
aluminum foil and stirred in the dark. Approximately 3 hours later, the red/brown color disappeared, and the mixture was colorless. At this time, a flame-dried $20 \mathrm{~mL}$ microwave tube was charged with Heck product $20(34 \mathrm{mg}, 0.056 \mathrm{mmol})$ in toluene $(9.3 \mathrm{~mL}, 0.006 \mathrm{M})$. The freshly prepared magnesium iodide etherate $(7.8 \mathrm{~mL}, 0.78 \mathrm{mmol}, 14$ equiv) was added dropwise to the starting material in toluene. The purple mixture was submerged in a $100{ }^{\circ} \mathrm{C}$ oil bath (note: a microwave tube, not a flask, is recommended for this reaction due to the heat requirement with ethereal solvent) and stirred for 4 hours. At this time, the flask was cooled for 10-15 minutes then quenched by the addition of water. The mixture was extracted with EtOAc, and the aqueous layer was acidified to $\mathrm{pH}=4$. The aqueous layer was extracted again with EtOAc, and the organic layers were washed with aqueous sat. $\mathrm{Na}_{2} \mathrm{~S}_{2} \mathrm{O}_{8}$ solution, water, and brine. The organics were dried over $\mathrm{Na}_{2} \mathrm{SO}_{4}$, filtered, and concentrated in vacuo to give the crude demethylated product SI-21. The product could either be quickly purified on a Teledyne-ISCO CombiFlash Rf-200 UV-Vis Automated Flash Chromatography System with a RediSep Rf High Performance Gold $15.5 \mathrm{~g}$ HP $\mathrm{C} 18$ column on a $5-100 \% \mathrm{MeCN}$ in $\mathrm{H}_{2} \mathrm{O}$ gradient, or immediately used in the next reaction. The crude mixture was dissolved in THF $(2 \mathrm{~mL})$, to which was added $3 \mathrm{~N} \mathrm{HCl}(285 \mu \mathrm{L})$ and stirred at $40^{\circ} \mathrm{C}$ in an oil bath for $2 \mathrm{~h}$. After cooling, the reaction was again extracted with EtOAc and washed with water and brine, dried over $\mathrm{Na}_{2} \mathrm{SO}_{4}$, filtered, and concentrated in vacuo. The crude product was purified on a Teledyne-ISCO CombiFlash Rf-200 UV-Vis Automated Flash Chromatography System with a RediSep Rf High Performance Gold $15.5 \mathrm{~g}$ HP C18 column on a 5-100\% MeCN in $\mathrm{H}_{2} \mathrm{O}$ gradient to give the natural product (+)-rubellin $\mathrm{C}$ as a yellow solid $(21 \mathrm{mg}, 67 \%$ over 2 steps) which matched the characterization data from the literature. ${ }^{\mathrm{S} 1}$

TLC (EtOAc): $\mathrm{R}_{f} 0.63$ (UV, visible yellow spot).

Reverse-phase TLC (3:1 MeOH:H $\mathrm{H}_{2} \mathrm{O}$, Merck TLC Silica gel 60 RP-18 $\mathrm{F}_{254} \mathrm{~S} 5$ x 10 glass plate): $\mathrm{R}_{f} 0.27$ (UV, visible yellow spot).

${ }^{1}$ H NMR (400 MHz, CDCl $)$ ): $\delta 12.54(\mathrm{~s}, 1 \mathrm{H}, \mathrm{O}-\mathrm{H}), 12.12(\mathrm{~s}, 1 \mathrm{H}, \mathrm{O}-\mathrm{H}), 7.79$ (dd, J = 7.6, $1.2 \mathrm{~Hz}$, $1 \mathrm{H}), 7.69(\mathrm{t}, J=7.9 \mathrm{~Hz}, 1 \mathrm{H}), 7.55(\mathrm{~s}, 1 \mathrm{H}, \mathrm{O}-\mathrm{H}), 7.31(\mathrm{dd}, J=8.4,1.1 \mathrm{~Hz}, 2 \mathrm{H}), 7.03(\mathrm{~s}, 1 \mathrm{H}), 6.70$ $(\mathrm{s}, 1 \mathrm{H}), 6.67(\mathrm{~s}, 1 \mathrm{H}), 5.92(\mathrm{dd}, J=10.1,2.8 \mathrm{~Hz}, 1 \mathrm{H}), 5.85(\mathrm{ddd}, \mathrm{J}=10.4,5.0,2.0 \mathrm{~Hz}, 1 \mathrm{H}), 5.64(\mathrm{~s}$, $1 \mathrm{H}), 4.66(\mathrm{~s}, 1 \mathrm{H}), 4.46-4.42(\mathrm{~m}, 1 \mathrm{H}), 4.32(\mathrm{t}, J=5.5 \mathrm{~Hz}, 1 \mathrm{H}), 4.13(\mathrm{~d}, J=19.7 \mathrm{~Hz}, 1 \mathrm{H}), 3.01(\mathrm{~d}$, $J=5.9 \mathrm{~Hz}, 1 \mathrm{H}), 2.94(\mathrm{~d}, J=18.5 \mathrm{~Hz}, 1 \mathrm{H}), 2.20(\mathrm{~s}, 3 \mathrm{H})$.

${ }^{1}$ H NMR (400 MHz, DMSO-d $\left.\mathbf{d}_{6}\right): \delta 7.79(\mathrm{dd}, J=8.4,7.5 \mathrm{~Hz}, 1 \mathrm{H}), 7.63(\mathrm{dd}, J=7.6,1.2 \mathrm{~Hz}, 1 \mathrm{H})$, $7.37(\mathrm{dd}, J=8.4,1.2 \mathrm{~Hz}, 1 \mathrm{H}), 7.29(\mathrm{~s}, 1 \mathrm{H}), 6.97(\mathrm{~s}, 1 \mathrm{H}), 6.71(\mathrm{~s}, 1 \mathrm{H}), 5.69-5.62(\mathrm{~m}, 2 \mathrm{H}), 5.52$ $(\mathrm{dd}, J=10.0,3.0 \mathrm{~Hz}, 1 \mathrm{H}), 5.14(\mathrm{~d}, J=4.1 \mathrm{~Hz}, 1 \mathrm{H}), 5.05(\mathrm{~d}, J=6.3 \mathrm{~Hz}, 1 \mathrm{H}), 4.45(\mathrm{~d}, J=18.6$, $1 \mathrm{H}), 4.17$ (d, $J=4.6 \mathrm{~Hz}, 1 \mathrm{H}), 4.09$ (t, $J=5.3 \mathrm{~Hz}, 1 \mathrm{H}), 3.90$ (d, $J=3.3 \mathrm{~Hz}, 1 \mathrm{H}), 3.08$ (d, $J=18.6$ $\mathrm{Hz}, 1 \mathrm{H}), 2.36(\mathrm{~s}, 3 \mathrm{H})$.

${ }^{13}$ C NMR (101 MHz, DMSO-d $\left.\mathbf{6}\right): \delta$ 191.4, 182.5, 166.8, 162.5, 161.2, 157.2, 156.4, 148.9, 146.6, $140.7,137.2,133.4,127.0,126.7,125.7,124.1,119.7,119.2,116.6,115.6,115.5,113.5,110.0$, 84.6, 67.5, 65.3, 52.1, 46.4, 37.5, 21.7 .

FTIR (ReactIR): 1740, 1665, 1626, 890, 730.

HRMS (ESI) m/z: $[\mathrm{M}-\mathrm{H}]^{-}$calc. $\mathrm{C}_{30} \mathrm{H}_{21} \mathrm{O}_{9} 525.1191$; found 525.1184.

$[\alpha]_{\mathbf{D}}^{25}:+200^{\circ}(\mathrm{c}=0.3, \mathrm{MeOH})$. Reported: $+193.6^{\circ}(\mathrm{c}=0.5, \mathrm{MeOH}) ;+220^{\circ}(\mathrm{c}=0.1, \mathrm{MeOH})^{\mathrm{S} 1, \mathrm{~S} 10}$ 
Table S5. ${ }^{1} \mathrm{H}$ NMR comparison of (+)-Rubellin C (1)

\begin{tabular}{|c|c|c|}
\hline Proton & $\begin{array}{c}\text { Arnone \& Nasini spectral data of } \\
\text { isolated (+)-rubellin C } \\
{ }^{1} \mathrm{H} \text { NMR, 300 MHz, DMSO-d } 6 \\
\text { Select multiplicities reported. } \\
{ }^{1} \mathrm{H} \delta(\text { multi., } J(\mathrm{~Hz}))\end{array}$ & $\begin{array}{c}\text { This work, spectral data of synthetic } \\
(+) \text {-rubellin C }\end{array}$ \\
\hline 2 & 7.38 & $\begin{array}{c}{ }^{1} \mathrm{H} \text { NMR, } 400 \mathrm{MHz}, \mathrm{DMSO}-\mathrm{d}_{6} \\
{ }^{1} \mathrm{H}(\text { multi., } J(\mathrm{~Hz}))\end{array}$ \\
\hline 3 & 7.80 & $7.37(\mathrm{dd}, J=8.4,1.2 \mathrm{~Hz})$ \\
\hline 4 & 7.64 & $7.79(\mathrm{dd}, J=8.4,7.5 \mathrm{~Hz})$ \\
\hline 7 & 7.30 & $7.29(\mathrm{~d})$ \\
\hline 11 & 3.90 & $3.90(\mathrm{~d}, J=3.3 \mathrm{~Hz})$ \\
\hline 12 & 5.52 & $5.52(\mathrm{dd}, J=10.0,3.0 \mathrm{~Hz})$ \\
\hline 13 & 5.65 & $5.65(\mathrm{~m})$ \\
\hline 14 & 4.17 & $4.09(\mathrm{~d}, J=5.3 \mathrm{~Hz})$ \\
\hline 15 & 4.09 & $4.45(\mathrm{dd}, J=18.6 \mathrm{~Hz})$ \\
\hline $17 \alpha$ & $4.45(\mathrm{~d}, J=18.5 \mathrm{~Hz})$ & $3.08(\mathrm{~d}, J=18.6 \mathrm{~Hz})$ \\
\hline $17 \beta$ & $3.09(\mathrm{~d}, J=18.5 \mathrm{~Hz})$ & $5.67(\mathrm{~s})$ \\
\hline 18 & 5.67 & $6.97(\mathrm{~s})$ \\
\hline 20 & 6.98 & $6.71(\mathrm{~s})$ \\
\hline 22 & 6.72 & $2.36(\mathrm{~s})$ \\
\hline 26 & 2.36 & - \\
\hline $1-\mathrm{OH}$ & $12.01, \mathrm{~s}$ & - \\
\hline $8-\mathrm{OH}$ & $12.54, \mathrm{~s}$ & $5.14(\mathrm{~d}, J=4.1 \mathrm{~Hz})$ \\
\hline $14-\mathrm{OH}$ & $5.15, \mathrm{brs}$ & $5.05(\mathrm{~d}, J=6.3 \mathrm{~Hz})$ \\
\hline $15-\mathrm{OH}$ & $5.07, \mathrm{brs}$ & - \\
\hline $23-\mathrm{OH}$ & $10.44, \mathrm{~s}$ & \\
\hline & & \\
\hline
\end{tabular}


Table S6. ${ }^{13} \mathrm{C}$ NMR comparison of (+)-Rubellin C (1)

\begin{tabular}{|c|c|c|}
\hline Carbon & $\begin{array}{l}\text { Arnone \& Nasini spectral data of } \\
\text { isolated (+)-rubellin C } \\
{ }^{13} \mathrm{C} \text { NMR, 75.47 MHz, DMSO-d } 6 \\
{ }^{13} \mathrm{C}(\delta)\end{array}$ & $\begin{array}{l}\text { This work, spectral data of synthetic } \\
(+) \text {-rubellin C } \\
{ }^{13} \mathrm{C} \text { NMR, }{ }_{101}^{10} \mathrm{MHz}, \text { DMSO-d } 6 \\
{ }^{13} \mathrm{C}(\delta)\end{array}$ \\
\hline 1 & 161.2 & 161.2 \\
\hline 2 & 123.9 & 124.1 \\
\hline 3 & 137.1 & 137.2 \\
\hline 4 & 119.3 & 119.2 \\
\hline $4 \mathrm{a}$ & 133.4 & 133.4 \\
\hline 5 & 140.7 & 140.7 \\
\hline 6 & 157.3 & 157.2 \\
\hline 7 & 119.7 & 119.7 \\
\hline 8 & 162.7 & 162.5 \\
\hline $8 \mathrm{a}$ & 113.5 & 113.5 \\
\hline 9 & 191.5 & 191.4 \\
\hline $9 a$ & 115.4 & 115.5 \\
\hline 10 & 182.4 & 182.5 \\
\hline $10 \mathrm{a}$ & 125.9 & 125.7 \\
\hline 11 & 46.7 & 46.4 \\
\hline 12 & 127.2 & 127.0 \\
\hline 13 & 126.7 & 126.7 \\
\hline 14 & 65.4 & 65.3 \\
\hline 15 & 67.7 & 67.5 \\
\hline 16 & 52.5 & 52.1 \\
\hline 17 & 37.5 & 37.5 \\
\hline 18 & 84.7 & 84.6 \\
\hline 19 & 149.0 & 148.9 \\
\hline 20 & 115.6 & 115.6 \\
\hline 21 & 146.7 & 146.6 \\
\hline 22 & 116.8 & 116.6 \\
\hline 23 & 156.5 & 156.4 \\
\hline 24 & 110.2 & 110.0 \\
\hline 25 & 167.1 & 166.8 \\
\hline 26 & 21.7 & 21.7 \\
\hline
\end{tabular}




\section{Single Crystal X-Ray Diffraction Data of Phenol 14 and Anthraquinone 19}

Compound 14 (JG-II-127) X-Ray crystal diffraction data: Crystals were grown in slow diffusion with DCM/Hexanes as clusters of colorless prisms. View of molecule $\mathbf{1 4}$ showing the atom labeling scheme. Displacement ellipsoids are scaled to the $50 \%$ probability level. The disorder in the phenyl ring is not shown. The data were collected on an Agilent Technologies SuperNova Dual Source diffractometer using a $\mu$-focus $\mathrm{Cu} \mathrm{K \alpha}$ radiation source $(\lambda=1.5418 \AA)$ with collimating mirror monochromators.

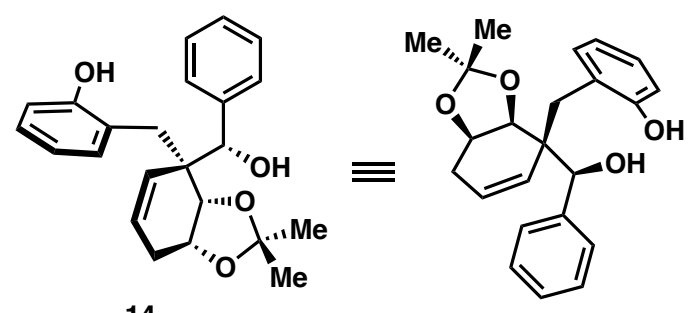

14

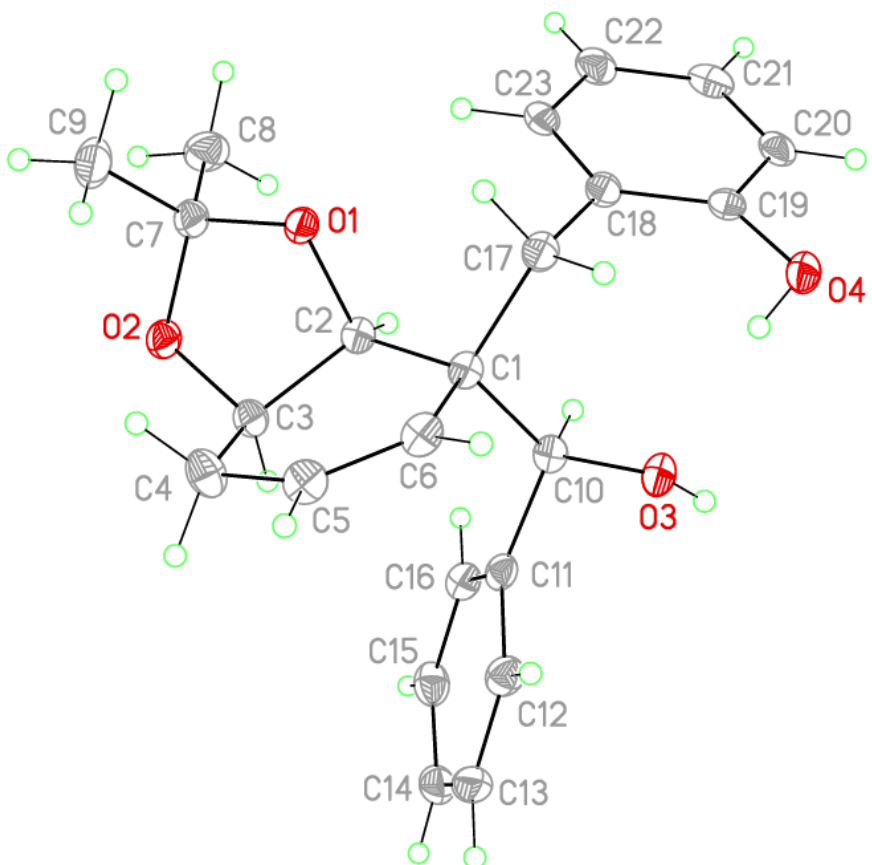

Table 1. Crystal data and structure refinement for JG-II-127.

Empirical formula

Formula weight

$\mathrm{C} 23 \mathrm{H} 26 \mathrm{O} 4$

Temperature

Wavelength

366.44

$100(2) \mathrm{K}$

Crystal system

$1.54184 \AA$

orthorhombic 
Space group

Unit cell dimensions

Volume

Z

Density (calculated)

Absorption coefficient

$\mathrm{F}(000)$

Crystal size

Theta range for data collection

Index ranges

Reflections collected

Independent reflections

Completeness to theta $=67.684^{\circ}$

Absorption correction

Max. and min. transmission

Refinement method

Data / restraints / parameters

Goodness-of-fit on $\mathrm{F}^{2}$

Final $\mathrm{R}$ indices [I $>2 \operatorname{sigma}(\mathrm{I})]$

$\mathrm{R}$ indices (all data)

Absolute structure parameter

Extinction coefficient

Largest diff. peak and hole
P 212121

$\begin{array}{ll}\mathrm{a}=6.33010(10) \AA & \alpha=90^{\circ} . \\ \mathrm{b}=14.8171(2) \AA & \beta=90^{\circ} . \\ \mathrm{c}=19.9096(4) \AA & \gamma=90^{\circ} . \\ 1867.40(5) \AA^{3} & \\ 4 & \\ 1.303 \mathrm{Mg} / \mathrm{m}^{3} & \\ 0.707 \mathrm{~mm}^{-1} & \\ 784 & \\ 0.300 \times 0.250 \times 0.130 \mathrm{~mm}^{3} & \\ 3.719 \text { to } 75.798^{\circ} . \\ -7<=\mathrm{h}<=7,-18<=\mathrm{k}<=18,-24<=1<=24 \\ 29893 \\ 3865[\mathrm{R}(\text { int })=0.0706] \\ 100.0 \% \\ \text { Semi-empirical from equivalents } \\ 1.00 \text { and } 0.507 \\ \text { Full-matrix least-squares on } \mathrm{F}^{2} \\ 3865 / 25 / 278 \\ 1.021 \\ \mathrm{R} 1=0.0371, \mathrm{wR} 2=0.0993 \\ \mathrm{R} 1=0.0371, \mathrm{wR} 2=0.0994 \\ 0.0(2) \\ \mathrm{n} / \mathrm{a} \\ 0.338 \text { and }-0.264 \text { e. } \AA^{-3}\end{array}$


Table 2. Atomic coordinates ( $\left.\times 10^{4}\right)$ and equivalent isotropic displacement parameters $\left(\AA^{2} \times 10^{3}\right)$ for JG-II-127. $\quad \mathrm{U}(\mathrm{eq})$ is defined as one third of the trace of the orthogonalized $\mathrm{U}^{\mathrm{ij}}$ tensor.

\begin{tabular}{|c|c|c|c|c|}
\hline & $\mathrm{x}$ & $\mathrm{y}$ & $\mathrm{z}$ & $\mathrm{U}(\mathrm{eq})$ \\
\hline $\mathrm{C} 1$ & 2619(3) & $5534(1)$ & 6972(1) & $15(1)$ \\
\hline $\mathrm{C} 2$ & 4107(3) & 4723(1) & $6862(1)$ & $15(1)$ \\
\hline C3 & $3877(3)$ & $3906(1)$ & $7324(1)$ & $17(1)$ \\
\hline $\mathrm{C} 4$ & 1578(3) & 3643(1) & $7476(1)$ & $23(1)$ \\
\hline $\mathrm{C} 5$ & 21(3) & 4397(1) & 7411(1) & $20(1)$ \\
\hline C6 & $460(3)$ & $5219(1)$ & $7187(1)$ & 19(1) \\
\hline C7 & $4701(3)$ & $3452(1)$ & $6226(1)$ & $20(1)$ \\
\hline C8 & $6906(4)$ & $3498(2)$ & $5927(1)$ & $27(1)$ \\
\hline C9 & $3298(4)$ & $2787(1)$ & $5858(1)$ & $31(1)$ \\
\hline $\mathrm{C} 10$ & $3593(3)$ & $6179(1)$ & $7510(1)$ & $15(1)$ \\
\hline C11 & $3870(3)$ & 5813(1) & $8218(1)$ & $16(1)$ \\
\hline C12 & 2195(3) & $5830(1)$ & $8675(1)$ & $20(1)$ \\
\hline $\mathrm{C} 13$ & $2522(4)$ & $5586(1)$ & $9343(1)$ & $24(1)$ \\
\hline C14 & $4505(4)$ & $5318(1)$ & $9558(1)$ & $24(1)$ \\
\hline C15 & 6171(4) & $5271(1)$ & $9104(1)$ & $23(1)$ \\
\hline $\mathrm{C} 16$ & $5842(3)$ & $5526(1)$ & $8439(1)$ & 19(1) \\
\hline $\mathrm{C} 17$ & 2393(3) & $6078(1)$ & $6305(1)$ & $18(1)$ \\
\hline O1 & $3689(2)$ & $4310(1)$ & $6220(1)$ & $18(1)$ \\
\hline $\mathrm{O} 2$ & $4906(2)$ & $3215(1)$ & $6929(1)$ & 19(1) \\
\hline $\mathrm{O} 3$ & $2253(2)$ & 6961(1) & $7534(1)$ & $18(1)$ \\
\hline $\mathrm{O} 4$ & 2987(3) & $8028(1)$ & $6449(1)$ & $21(1)$ \\
\hline C18 & $4261(6)$ & $6574(3)$ & $6044(1)$ & $17(1)$ \\
\hline C19 & $4473(6)$ & $7515(3)$ & $6135(1)$ & $16(1)$ \\
\hline $\mathrm{C} 20$ & $6235(6)$ & 7971(2) & $5886(1)$ & $20(1)$ \\
\hline $\mathrm{C} 21$ & $7810(6)$ & $7504(2)$ & $5539(1)$ & $22(1)$ \\
\hline $\mathrm{C} 22$ & $7610(7)$ & $6580(2)$ & $5448(2)$ & $22(1)$ \\
\hline $\mathrm{C} 23$ & $5885(7)$ & $6129(2)$ & $5700(1)$ & 19(1) \\
\hline $\mathrm{O} 4 \mathrm{~A}$ & $5987(12)$ & $5387(5)$ & $5438(3)$ & 19 \\
\hline C18A & $4400(30)$ & $6651(13)$ & $6062(6)$ & 19 \\
\hline C19A & $6000(30)$ & $6258(9)$ & $5653(6)$ & 19 \\
\hline $\mathrm{C} 20 \mathrm{~A}$ & $7730(30)$ & $6768(11)$ & $5445(7)$ & 19 \\
\hline $\mathrm{C} 21 \mathrm{~A}$ & $7940(30)$ & $7664(11)$ & $5631(7)$ & 19 \\
\hline C22A & $6390(30)$ & $8049(11)$ & $6027(7)$ & 19 \\
\hline $\mathrm{C} 23 \mathrm{~A}$ & $4690(30)$ & $7548(13)$ & $6230(7)$ & 19 \\
\hline
\end{tabular}


Table 3. Bond lengths $[\AA]$ and angles $\left[{ }^{\circ}\right]$ for JG-II- 127 .

\begin{tabular}{|c|c|c|c|}
\hline$\overline{\mathrm{C} 1-\mathrm{C} 6}$ & $1.506(3)$ & C14-C15 & $1.392(3)$ \\
\hline $\mathrm{C} 1-\mathrm{C} 2$ & $1.543(2)$ & C14-H14 & 0.95 \\
\hline C1-C17 & $1.559(2)$ & $\mathrm{C} 15-\mathrm{C} 16$ & $1.391(3)$ \\
\hline $\mathrm{C} 1-\mathrm{C} 10$ & $1.562(3)$ & C15-H15 & 0.95 \\
\hline $\mathrm{C} 2-\mathrm{O} 1$ & $1.441(2)$ & C16-H16 & 0.95 \\
\hline $\mathrm{C} 2-\mathrm{C} 3$ & $1.527(3)$ & $\mathrm{C} 17-\mathrm{C} 18$ & $1.486(5)$ \\
\hline $\mathrm{C} 2-\mathrm{H} 2$ & 1.00 & C17-C18A & $1.602(19)$ \\
\hline $\mathrm{C} 3-\mathrm{O} 2$ & $1.446(2)$ & C17-H17A & 0.99 \\
\hline $\mathrm{C} 3-\mathrm{C} 4$ & $1.536(3)$ & C17-H17B & 0.99 \\
\hline C3-H3 & 1.00 & $\mathrm{O} 3-\mathrm{H} 3 \mathrm{O}$ & $0.83(4)$ \\
\hline C4-C5 & $1.495(3)$ & O4-C19 & $1.363(5)$ \\
\hline C4-H4A & 0.99 & O4-H4O & $0.86(5)$ \\
\hline C4-H4B & 0.99 & $\mathrm{C} 18-\mathrm{C} 23$ & $1.400(5)$ \\
\hline $\mathrm{C} 5-\mathrm{C} 6$ & $1.327(3)$ & C18-C19 & $1.413(4)$ \\
\hline $\mathrm{C} 5-\mathrm{H} 5$ & 0.95 & C19-C20 & $1.395(4)$ \\
\hline C6-H6 & 0.95 & C20-C21 & $1.396(4)$ \\
\hline C7-O1 & $1.425(2)$ & $\mathrm{C} 20-\mathrm{H} 20$ & 0.95 \\
\hline $\mathrm{C} 7-\mathrm{O} 2$ & $1.449(2)$ & $\mathrm{C} 21-\mathrm{C} 22$ & $1.386(4)$ \\
\hline C7-C9 & $1.515(3)$ & $\mathrm{C} 21-\mathrm{H} 21$ & 0.95 \\
\hline C7-C8 & $1.519(3)$ & $\mathrm{C} 22-\mathrm{C} 23$ & $1.375(4)$ \\
\hline C8-H8A & 0.98 & $\mathrm{C} 22-\mathrm{H} 22$ & 0.95 \\
\hline C8-H8B & 0.98 & $\mathrm{C} 23-\mathrm{H} 23$ & 0.95 \\
\hline $\mathrm{C} 8-\mathrm{H} 8 \mathrm{C}$ & 0.98 & O4A-C19A & $1.360(13)$ \\
\hline C9-H9A & 0.98 & O4A-H4OA & 0.8400 \\
\hline C9-H9B & 0.98 & C18A-C23A & $1.383(14)$ \\
\hline C9-H9C & 0.98 & C18A-C19A & $1.425(13)$ \\
\hline $\mathrm{C} 10-\mathrm{O} 3$ & $1.437(2)$ & C19A-C20A & $1.394(13)$ \\
\hline C10-C11 & $1.521(3)$ & $\mathrm{C} 20 \mathrm{~A}-\mathrm{C} 21 \mathrm{~A}$ & $1.384(12)$ \\
\hline C10-H10 & 1.00 & C20A-H20A & 0.95 \\
\hline $\mathrm{C} 11-\mathrm{C} 16$ & $1.390(3)$ & $\mathrm{C} 21 \mathrm{~A}-\mathrm{C} 22 \mathrm{~A}$ & $1.383(13)$ \\
\hline $\mathrm{C} 11-\mathrm{C} 12$ & $1.397(3)$ & C21A-H21A & 0.95 \\
\hline C12-C13 & $1.392(3)$ & $\mathrm{C} 22 \mathrm{~A}-\mathrm{C} 23 \mathrm{~A}$ & $1.366(13)$ \\
\hline C12-H12 & 0.95 & $\mathrm{C} 22 \mathrm{~A}-\mathrm{H} 22 \mathrm{~A}$ & 0.95 \\
\hline C13-C14 & $1.385(3)$ & $\mathrm{C} 23 \mathrm{~A}-\mathrm{H} 23 \mathrm{~A}$ & 0.95 \\
\hline C13-H13 & 0.95 & & \\
\hline $\mathrm{C} 6-\mathrm{C} 1-\mathrm{C} 2$ & $110.65(15)$ & $\mathrm{C} 5-\mathrm{C} 4-\mathrm{C} 3$ & $114.73(16)$ \\
\hline C6-C1-C17 & 108.62(15) & C5-C4-H4A & 108.6 \\
\hline $\mathrm{C} 2-\mathrm{C} 1-\mathrm{C} 17$ & $109.76(15)$ & C3-C4-H4A & 108.6 \\
\hline C6-C1-C10 & $110.63(15)$ & C5-C4-H4B & 108.6 \\
\hline $\mathrm{C} 2-\mathrm{C} 1-\mathrm{C} 10$ & 109.41(15) & C3-C4-H4B & 108.6 \\
\hline C17-C1-C10 & 107.71(15) & H4A-C4-H4B & 107.6 \\
\hline $\mathrm{O} 1-\mathrm{C} 2-\mathrm{C} 3$ & $100.37(14)$ & C6-C5-C4 & $125.20(19)$ \\
\hline $\mathrm{O} 1-\mathrm{C} 2-\mathrm{C} 1$ & $110.12(14)$ & C6-C5-H5 & 117.4 \\
\hline C3-C2-C1 & $118.30(16)$ & C4-C5-H5 & 117.4 \\
\hline $\mathrm{O} 1-\mathrm{C} 2-\mathrm{H} 2$ & 109.2 & $\mathrm{C} 5-\mathrm{C} 6-\mathrm{C} 1$ & $124.79(18)$ \\
\hline $\mathrm{C} 3-\mathrm{C} 2-\mathrm{H} 2$ & 109.2 & C5-C6-H6 & 117.6 \\
\hline $\mathrm{C} 1-\mathrm{C} 2-\mathrm{H} 2$ & 109.2 & C1-C6-H6 & 117.6 \\
\hline $\mathrm{O} 2-\mathrm{C} 3-\mathrm{C} 2$ & $101.02(14)$ & $\mathrm{O} 1-\mathrm{C} 7-\mathrm{O} 2$ & $105.31(15)$ \\
\hline $\mathrm{O} 2-\mathrm{C} 3-\mathrm{C} 4$ & $110.73(16)$ & $\mathrm{O} 1-\mathrm{C} 7-\mathrm{C} 9$ & $108.28(17)$ \\
\hline $\mathrm{C} 2-\mathrm{C} 3-\mathrm{C} 4$ & $114.17(16)$ & $\mathrm{O} 2-\mathrm{C} 7-\mathrm{C} 9$ & $111.23(17)$ \\
\hline $\mathrm{O} 2-\mathrm{C} 3-\mathrm{H} 3$ & 110.2 & $\mathrm{O} 1-\mathrm{C} 7-\mathrm{C} 8$ & 111.71(17) \\
\hline $\mathrm{C} 2-\mathrm{C} 3-\mathrm{H} 3$ & 110.2 & $\mathrm{O} 2-\mathrm{C} 7-\mathrm{C} 8$ & $107.87(17)$ \\
\hline $\mathrm{C} 4-\mathrm{C} 3-\mathrm{H} 3$ & 110.2 & C9-C7-C8 & $112.23(18)$ \\
\hline
\end{tabular}




$\begin{array}{llll}\text { C7-C8-H8A } & 109.5 & \text { H17A-C17-H17B } & 107.1 \\ \text { C7-C8-H8B } & 109.5 & \text { C7-O1-C2 } & 106.84(14) \\ \text { H8A-C8-H8B } & 109.5 & \text { C3-O2-C7 } & 108.26(14) \\ \text { C7-C8-H8C } & 109.5 & \text { C10-O3-H3O } & 103(2) \\ \text { H8A-C8-H8C } & 109.5 & \text { C19-O4-H4O } & 107(3) \\ \text { H8B-C8-H8C } & 109.5 & \text { C23-C18-C19 } & 117.2(3) \\ \text { C7-C9-H9A } & 109.5 & \text { C23-C18-C17 } & 121.5(3) \\ \text { C7-C9-H9B } & 109.5 & \text { C19-C18-C17 } & 121.2(4) \\ \text { H9A-C9-H9B } & 109.5 & \text { O4-C19-C20 } & 116.4(3) \\ \text { C7-C9-H9C } & 109.5 & \text { O4-C19-C18 } & 123.0(3) \\ \text { H9A-C9-H9C } & 109.5 & \text { C20-C19-C18 } & 120.6(3) \\ \text { H9B-C9-H9C } & 109.5 & \text { C19-C20-C21 } & 120.4(3) \\ \text { O3-C10-C11 } & 108.95(15) & \text { C19-C20-H20 } & 119.8 \\ \text { O3-C10-C1 } & 106.43(15) & \text { C21-C20-H20 } & 119.8 \\ \text { C11-C10-C1 } & 117.64(15) & \text { C22-C21-C20 } & 119.3(3) \\ \text { O3-C10-H10 } & 107.8 & \text { C22-C21-H21 } & 120.3 \\ \text { C11-C10-H10 } & 107.8 & \text { C20-C21-H21 } & 120.3 \\ \text { C1-C10-H10 } & 107.8 & \text { C23-C22-C21 } & 120.3(3) \\ \text { C16-C11-C12 } & 118.72(17) & \text { C23-C22-H22 } & 119.9 \\ \text { C16-C11-C10 } & 120.40(17) & \text { C21-C22-H22 } & 119.9 \\ \text { C12-C11-C10 } & 120.66(18) & \text { C22-C23-C18 } & 122.2(3) \\ \text { C13-C12-C11 } & \text { C18-C23-H23 } & 118.9 \\ \text { C13-C12-H12 } & 120.3(2) & \text { C19A-O4A-H4OA } & 118.9 \\ \text { C11-C12-H12 } & 119.9 & \text { C23A-C18A-C19A } & 109.5 \\ \text { C14-C13-C12 } & 119.9 & \text { C23A-C18A-C17 } & 115.7(12) \\ \text { C14-C13-H13 } & 120.3(2) & \text { C19A-C18A-C17 } & 122.9(14) \\ \text { C12-C13-H13 } & 119.8 & \text { O4A-C19A-C20A } & 121.3(14) \\ \text { C13-C14-C15 } & 119.8 & \text { O4A-C19A-C18A } & 115.2(14) \\ \text { C13-C14-H14 } & 119.95(19) & \text { C20A-C19A-C18A } & 124.3(14) \\ \text { C15-C14-H14 } & 120.0 & \text { C21A-C20A-C19A } & 120.5(12) \\ \text { C16-C15-C14 } & 120.0 & \text { C21A-C20A-H20A } & 121.0(14) \\ \text { C16-C15-H15 } & 119.4(2) & \text { C22A-C21A-C20A } & 119.5 \\ \text { C14-C15-H15 } & \text { C20A-C21A-H21A } & 119.5 \\ \text { C11-C16-C15 } & \text { C23A-C22A-C21A } & 118.7(13) \\ \text { C11-C16-H16 } & \text { C23A-C22A-H22A } & 120.6 \\ \text { C15-C16-H16 } & \text { C21A-C22A-H22A } & 120.6 \\ \text { C18-C17-C1 } & \text { C22A-C23A-C18A } & 120.1(14) \\ \text { C1-C17-C18A } & 120.3 & 120.0 \\ \text { C18-C17-H17A } & 120.3 & 120.0 \\ \text { C1-C17-H17A } & 11.24(19) & 123.9(15) \\ \text { C18-C17-H17B } & 118.4 & 118.0 \\ \text { C1-C17-H17B } & 117.3(2) & 118.0 \\ & 107.6 & & \end{array}$


Table 4. Anisotropic displacement parameters $\left(\AA^{2} \times 10^{3}\right)$ for JG-II-127. The anisotropic displacement factor exponent takes the form: $\quad-2 \pi^{2}\left[\mathrm{~h}^{2} \mathrm{a}^{* 2} \mathrm{U}^{11}+\ldots \quad+2 \mathrm{hka} \mathrm{a}^{*} \mathrm{~b}^{*} \mathrm{U}^{12}\right]$

\begin{tabular}{|c|c|c|c|c|c|c|}
\hline & $\mathrm{U}^{11}$ & $\mathrm{U}^{22}$ & $\mathrm{U}^{33}$ & $\mathrm{U}^{23}$ & $\mathrm{U}^{13}$ & $\mathrm{U}^{12}$ \\
\hline$\overline{\mathrm{C} 1}$ & 14(1) & $15(1)$ & $17(1)$ & $-1(1)$ & $-1(1)$ & $1(1)$ \\
\hline $\mathrm{C} 2$ & $14(1)$ & $15(1)$ & $17(1)$ & $-1(1)$ & $-2(1)$ & 1(1) \\
\hline $\mathrm{C} 3$ & $17(1)$ & $16(1)$ & $19(1)$ & $2(1)$ & $-1(1)$ & 1(1) \\
\hline $\mathrm{C} 4$ & $18(1)$ & 21(1) & $30(1)$ & $5(1)$ & 1(1) & $-2(1)$ \\
\hline C5 & $14(1)$ & $23(1)$ & $24(1)$ & $-1(1)$ & $1(1)$ & $-2(1)$ \\
\hline C6 & $14(1)$ & $20(1)$ & $22(1)$ & $-4(1)$ & $-2(1)$ & $-1(1)$ \\
\hline C7 & $26(1)$ & $15(1)$ & $19(1)$ & $0(1)$ & $-3(1)$ & $3(1)$ \\
\hline C8 & $30(1)$ & $28(1)$ & $24(1)$ & $-1(1)$ & $5(1)$ & $9(1)$ \\
\hline C9 & $46(1)$ & $16(1)$ & $30(1)$ & $-2(1)$ & $-13(1)$ & $0(1)$ \\
\hline C10 & 11(1) & $15(1)$ & $19(1)$ & $-1(1)$ & $0(1)$ & $0(1)$ \\
\hline C11 & $16(1)$ & $13(1)$ & $18(1)$ & $-3(1)$ & $0(1)$ & $-3(1)$ \\
\hline C12 & $18(1)$ & 19(1) & $22(1)$ & $-2(1)$ & $2(1)$ & $0(1)$ \\
\hline C13 & $30(1)$ & 21(1) & $21(1)$ & $-2(1)$ & $7(1)$ & $-5(1)$ \\
\hline C14 & $35(1)$ & $18(1)$ & $19(1)$ & 1(1) & $-3(1)$ & $-5(1)$ \\
\hline C15 & $25(1)$ & $18(1)$ & $26(1)$ & 1(1) & $-6(1)$ & $1(1)$ \\
\hline C16 & $18(1)$ & $18(1)$ & 21(1) & $-2(1)$ & $0(1)$ & $0(1)$ \\
\hline C17 & 19(1) & $16(1)$ & $18(1)$ & $-1(1)$ & $-5(1)$ & $2(1)$ \\
\hline $\mathrm{O} 1$ & $23(1)$ & $14(1)$ & $16(1)$ & $-1(1)$ & $-2(1)$ & $2(1)$ \\
\hline $\mathrm{O} 2$ & $23(1)$ & $15(1)$ & $19(1)$ & $0(1)$ & $-2(1)$ & $4(1)$ \\
\hline $\mathrm{O} 3$ & $19(1)$ & $14(1)$ & $22(1)$ & $-2(1)$ & $-3(1)$ & $2(1)$ \\
\hline $\mathrm{O} 4$ & $25(1)$ & $15(1)$ & $23(1)$ & $0(1)$ & $4(1)$ & $4(1)$ \\
\hline C18 & $20(1)$ & $16(1)$ & $15(1)$ & 1(1) & $-4(1)$ & $2(1)$ \\
\hline C19 & $20(2)$ & $18(1)$ & $12(1)$ & 1(1) & $-4(1)$ & 1(1) \\
\hline $\mathrm{C} 20$ & $28(1)$ & $18(1)$ & $15(1)$ & $4(1)$ & $-7(1)$ & $-4(1)$ \\
\hline C21 & $20(1)$ & $29(2)$ & $16(1)$ & $5(1)$ & $-2(1)$ & $-6(1)$ \\
\hline C22 & $22(1)$ & $25(2)$ & $20(1)$ & $5(1)$ & $0(1)$ & $6(1)$ \\
\hline $\mathrm{C} 23$ & $24(1)$ & $17(1)$ & $15(1)$ & $4(1)$ & $-1(1)$ & $4(1)$ \\
\hline
\end{tabular}


Table 5. Hydrogen coordinates ( $\left.\times 10^{4}\right)$ and isotropic displacement parameters $\left(\AA^{2} \times 10^{3}\right)$ for JG-II-127.

\begin{tabular}{|c|c|c|c|c|}
\hline & $\mathrm{x}$ & $y$ & $\mathrm{z}$ & $\mathrm{U}(\mathrm{eq})$ \\
\hline $\mathrm{H} 2$ & 5605 & 4937 & 6873 & 18 \\
\hline $\mathrm{H} 3$ & 4668 & 4008 & 7752 & 21 \\
\hline $\mathrm{H} 4 \mathrm{~A}$ & 1158 & 3152 & 7166 & 28 \\
\hline H4B & 1505 & 3403 & 7939 & 28 \\
\hline H5 & -1396 & 4278 & 7540 & 24 \\
\hline H6 & -669 & 5640 & 7160 & 22 \\
\hline H8A & 6809 & 3650 & 5449 & 41 \\
\hline H8B & 7604 & 2911 & 5978 & 41 \\
\hline $\mathrm{H} 8 \mathrm{C}$ & 7728 & 3962 & 6161 & 41 \\
\hline H9A & 1916 & 2760 & 6079 & 46 \\
\hline H9B & 3953 & 2188 & 5866 & 46 \\
\hline H9C & 3118 & 2983 & 5392 & 46 \\
\hline H10 & 5011 & 6375 & 7344 & 18 \\
\hline $\mathrm{H} 12$ & 828 & 6007 & 8530 & 24 \\
\hline H13 & 1379 & 5604 & 9651 & 28 \\
\hline H14 & 4727 & 5166 & 10017 & 29 \\
\hline H15 & 7521 & 5066 & 9246 & 28 \\
\hline H16 & 6986 & 5504 & 8131 & 23 \\
\hline H17A & 1927 & 5652 & 5952 & 21 \\
\hline H17B & 1240 & 6522 & 6368 & 21 \\
\hline $\mathrm{H} 20$ & 6364 & 8603 & 5953 & 24 \\
\hline H21 & 9006 & 7815 & 5368 & 26 \\
\hline H22 & 8670 & 6258 & 5210 & 26 \\
\hline $\mathrm{H} 23$ & 5792 & 5495 & 5639 & 22 \\
\hline $\mathrm{H} 4 \mathrm{OA}$ & 4901 & 5126 & 5583 & 29 \\
\hline H20A & 8785 & 6496 & 5172 & 23 \\
\hline H21A & 9127 & 8007 & 5489 & 23 \\
\hline $\mathrm{H} 22 \mathrm{~A}$ & 6501 & 8664 & 6158 & 23 \\
\hline H23A & 3657 & 7832 & 6502 & 23 \\
\hline $\mathrm{H} 3 \mathrm{O}$ & $2980(50)$ & $7330(20)$ & $7739(16)$ & $36(8)$ \\
\hline $\mathrm{H} 4 \mathrm{O}$ & $2260(80)$ & $7670(30)$ & $6700(20)$ & $50(12)$ \\
\hline
\end{tabular}


Table 6. Torsion angles $\left[{ }^{\circ}\right]$ for JG-II-127.

\begin{tabular}{lc}
\hline C6-C1-C2-O1 & $79.02(18)$ \\
C17-C1-C2-O1 & $-40.8(2)$ \\
C10-C1-C2-O1 & $-158.83(15)$ \\
C6-C1-C2-C3 & $-35.5(2)$ \\
C17-C1-C2-C3 & $-155.36(16)$ \\
C10-C1-C2-C3 & $86.7(2)$ \\
O1-C2-C3-O2 & $40.48(17)$ \\
C1-C2-C3-O2 & $160.21(15)$ \\
O1-C2-C3-C4 & $-78.37(19)$ \\
C1-C2-C3-C4 & $41.3(2)$ \\
O2-C3-C4-C5 & $-137.96(18)$ \\
C2-C3-C4-C5 & $-24.8(3)$ \\
C3-C4-C5-C6 & $5.7(3)$ \\
C4-C5-C6-C1 & $-1.1(3)$ \\
C2-C1-C6-C5 & $15.4(3)$ \\
C17-C1-C6-C5 & $135.9(2)$ \\
C10-C1-C6-C5 & $-106.0(2)$ \\
C6-C1-C10-O3 & $-63.95(18)$ \\
C2-C1-C10-O3 & $173.89(14)$ \\
C17-C1-C10-O3 & $54.63(19)$ \\
C6-C1-C10-C11 & $58.5(2)$ \\
C2-C1-C10-C11 & $-63.7(2)$ \\
C17-C1-C10-C11 & $177.08(15)$ \\
O3-C10-C11-C16 & $-137.56(17)$ \\
C1-C10-C11-C16 & $101.3(2)$ \\
O3-C10-C11-C12 & $37.1(2)$ \\
C1-C10-C11-C12 & $-84.1(2)$ \\
C16-C11-C12-C13 & $1.8(3)$ \\
C10-C11-C12-C13 & $-172.96(17)$ \\
C11-C12-C13-C14 & $-0.6(3)$ \\
C12-C13-C14-C15 & $-1.5(3)$ \\
C13-C14-C15-C16 & $2.3(3)$ \\
C12-C11-C16-C15 & $-1.0(3)$ \\
C10-C11-C16-C15 & $173.80(17)$ \\
C14-C15-C16-C11 & $-1.1(3)$ \\
C6-C1-C17-C18 & $171.2(2)$ \\
C2-C1-C17-C18 & $-67.7(3)$ \\
C10-C1-C17-C18 & $51.3(3)$ \\
C6-C1-C17-C18A & $167.6(8)$ \\
C2-C1-C17-C18A & $-71.3(8)$ \\
C10-C1-C17-C18A & $47.8(8)$ \\
O2-C7-O1-C2 & $23.47(19)$ \\
C9-C7-O1-C2 & $142.54(17)$ \\
C8-C7-O1-C2 & $-93.37(18)$ \\
C3-C2-O1-C7 & $-39.92(18)$ \\
C1-C2-O1-C7 & $-165.40(15)$ \\
C2-C3-O2-C7 & $-27.73(19)$ \\
C4-C3-O2-C7 & $93.58(18)$ \\
O1-C7-O2-C3 & $4.1(2)$ \\
C9-C7-O2-C3 & $-113.01(18)$ \\
C8-C7-O2-C3 & $123.50(17)$ \\
C1-C17-C18-C23 & $78.7(2)$ \\
C1-C17-C18-C19 & $178.74(16)$ \\
C23-C18-C19-O4 & \\
&
\end{tabular}




$\begin{array}{lc}\text { C17-C18-C19-O4 } & -1.5(2) \\ \text { C23-C18-C19-C20 } & 0.3(2) \\ \text { C17-C18-C19-C20 } & -179.94(14) \\ \text { O4-C19-C20-C21 } & -178.15(18) \\ \text { C18-C19-C20-C21 } & 0.3(3) \\ \text { C19-C20-C21-C22 } & -0.3(3) \\ \text { C20-C21-C22-C23 } & -0.4(3) \\ \text { C21-C22-C23-C18 } & 1.2(3) \\ \text { C19-C18-C23-C22 } & -1.1(3) \\ \text { C17-C18-C23-C22 } & 179.18(15) \\ \text { C1-C17-C18A-C23A } & -92.2(5) \\ \text { C1-C17-C18A-C19A } & 87.8(5) \\ \text { C23A-C18A-C19A-O4A } & 179.9(3) \\ \text { C17-C18A-C19A-O4A } & -0.1(4) \\ \text { C23A-C18A-C19A-C20A } & -0.1(4) \\ \text { C17-C18A-C19A-C20A } & 179.9(2) \\ \text { O4A-C19A-C20A-C21A } & -179.8(3) \\ \text { C18A-C19A-C20A-C21A } & 0.2(5) \\ \text { C19A-C20A-C21A-C22A } & -0.2(5) \\ \text { C20A-C21A-C22A-C23A } & 0.2(5) \\ \text { C21A-C22A-C23A-C18A } & -0.2(5) \\ \text { C19A-C18A-C23A-C22A } & 0.1(4) \\ \text { C17-C18A-C23A-C22A } & -179.9(3) \\ \end{array}$


Table 7. Hydrogen bonds for JG-II-127 [ $\AA$ and $\left.{ }^{\circ}\right]$.

\begin{tabular}{lcccc}
\hline D-H...A & $\mathrm{d}(\mathrm{D}-\mathrm{H})$ & $\mathrm{d}(\mathrm{H} \ldots \mathrm{A})$ & $\mathrm{d}(\mathrm{D} \ldots \mathrm{A})$ & $<$ (DHA) \\
\hline C3-H3..O4\#1 & & & & \\
O4A-H4OA...O1 & 1.00 & 2.62 & $3.405(3)$ & 135.9 \\
O3-H3O...O2\#2 & 0.84 & 1.91 & $2.662(7)$ & 147.9 \\
O4-H4O...O3 & $0.83(4)$ & $1.98(4)$ & $2.798(2)$ & $169(3)$ \\
& $0.86(5)$ & $1.96(5)$ & $2.716(2)$ & $146(4)$
\end{tabular}

Symmetry transformations used to generate equivalent atoms:

$\# 1-\mathrm{x}+1, \mathrm{y}-1 / 2,-\mathrm{z}+3 / 2 \quad \# 2-\mathrm{x}+1, \mathrm{y}+1 / 2,-\mathrm{z}+3 / 2$ 
Compound 19 (JG-IV-113) X-ray crystal diffraction data: Two views of molecule 19 showing the atom labeling scheme. Displacement ellipsoids are scaled to the $50 \%$ probability level. The methyl group hydrogen atoms have been omitted for clarity. The lower occupancy atoms of the disordered components have been omitted. Sample was prepared utilizing slow evaporation in absolute EtOH to give red needles. The data were collected on an Agilent Technologies SuperNova Dual Source diffractometer using a $\mu$-focus $\mathrm{Cu} K \alpha$ radiation source $(\lambda=1.5418 \AA)$ with collimating mirror monochromators.
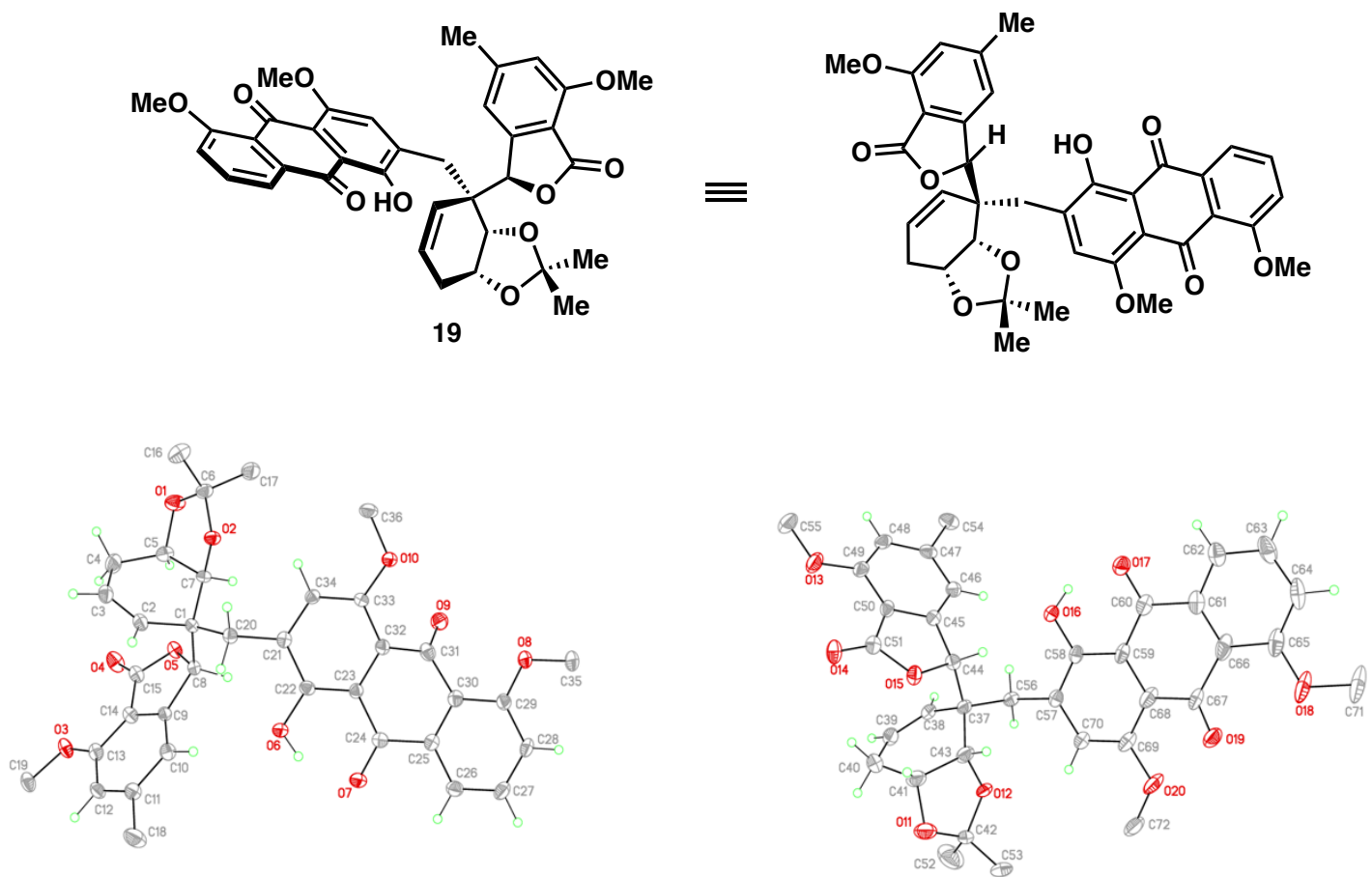

Table 1. Crystal data and structure refinement for JG-IV-113.

Empirical formula

Formula weight

Temperature

Wavelength

Crystal system

Space group

Unit cell dimensions

Volume

Z

Density (calculated)

Absorption coefficient

$\mathrm{F}(000)$

Crystal size

Theta range for data collection

Index ranges

Reflections collected

Independent reflections
$\mathrm{C} 36 \mathrm{H} 34 \mathrm{O} 10$

626.63

$100(2) \mathrm{K}$

$1.54184 \AA$

orthorhombic

P 212121

$\mathrm{a}=6.8762(5) \AA$

$\alpha=90^{\circ}$.

$\mathrm{b}=20.0284(8) \AA$

$\beta=90^{\circ}$.

$\mathrm{c}=44.3432(14) \AA \quad \gamma=90^{\circ}$.

6106.9(5) $\AA^{3}$

8

$1.363 \mathrm{Mg} / \mathrm{m}^{3}$

$0.825 \mathrm{~mm}^{-1}$

2640

$0.220 \times 0.056 \times 0.031 \mathrm{~mm}^{3}$

2.421 to $75.328^{\circ}$.

$-7<=\mathrm{h}<=8,-17<=\mathrm{k}<=24,-54<=\mathrm{l}<=51$

27668

$12251[\mathrm{R}(\mathrm{int})=0.0434]$ 
Completeness to theta $=67.684^{\circ}$

Absorption correction

Max. and min. transmission

Refinement method

Data / restraints / parameters

Goodness-of-fit on $\mathrm{F}^{2}$

Final $\mathrm{R}$ indices [I $>2$ sigma(I)]

$\mathrm{R}$ indices (all data)

Absolute structure parameter

Extinction coefficient

Largest diff. peak and hole
$99.9 \%$

Gaussian and multi-scan

1.00 and 0.858

Full-matrix least-squares on $\mathrm{F}^{2}$

12251 / 60 / 911

0.909

$\mathrm{R} 1=0.0511, \mathrm{wR} 2=0.1301$

$\mathrm{R} 1=0.0608, \mathrm{wR} 2=0.1391$

$0.16(10)$

$\mathrm{n} / \mathrm{a}$

0.557 and -0.305 e. $\AA^{-3}$ 
Table 2. Atomic coordinates ( $\left.\times 10^{4}\right)$ and equivalent isotropic displacement parameters $\left(\AA^{2} \times 10^{3}\right)$ for JG-IV-113. $\mathrm{U}(\mathrm{eq})$ is defined as one third of the trace of the orthogonalized $\mathrm{U}^{\mathrm{ij}}$ tensor.

\begin{tabular}{|c|c|c|c|c|}
\hline & $\mathrm{x}$ & $\mathrm{y}$ & $\mathrm{Z}$ & $\mathrm{U}(\mathrm{eq})$ \\
\hline $\mathrm{O} 1$ & $5202(4)$ & $3001(1)$ & $4935(1)$ & $28(1)$ \\
\hline $\mathrm{O} 2$ & $5547(4)$ & $4110(1)$ & $5041(1)$ & $17(1)$ \\
\hline $\mathrm{O} 3$ & $8107(4)$ & $2590(1)$ & $6592(1)$ & $23(1)$ \\
\hline $\mathrm{O} 4$ & $8497(4)$ & $2227(1)$ & $5948(1)$ & $29(1)$ \\
\hline $\mathrm{O} 5$ & $8872(3)$ & $3166(1)$ & $5679(1)$ & $18(1)$ \\
\hline O6 & $10368(4)$ & $5503(1)$ & $5763(1)$ & $24(1)$ \\
\hline $\mathrm{O} 7$ & $13580(4)$ & $6132(2)$ & $5740(1)$ & $26(1)$ \\
\hline O8 & $16848(4)$ & $6549(2)$ & $4514(1)$ & $27(1)$ \\
\hline O9 & $14493(4)$ & $5515(1)$ & $4595(1)$ & $26(1)$ \\
\hline O10 & $10645(4)$ & $5405(1)$ & $4524(1)$ & $23(1)$ \\
\hline $\mathrm{C} 1$ & $6960(5)$ & $4137(2)$ & $5534(1)$ & $16(1)$ \\
\hline $\mathrm{C} 2$ & $5086(5)$ & $4018(2)$ & $5704(1)$ & $18(1)$ \\
\hline C3 & $4050(5)$ & $3468(2)$ & $5676(1)$ & $21(1)$ \\
\hline $\mathrm{C} 4$ & $4564(6)$ & 2891(2) & $5474(1)$ & $26(1)$ \\
\hline $\mathrm{C} 5$ & $6059(5)$ & $3050(2)$ & $5230(1)$ & $21(1)$ \\
\hline C6 & $4888(5)$ & $3651(2)$ & $4815(1)$ & $20(1)$ \\
\hline $\mathrm{C} 7$ & $6880(5)$ & $3763(2)$ & $5230(1)$ & $15(1)$ \\
\hline $\mathrm{C} 8$ & $8712(5)$ & $3881(2)$ & $5720(1)$ & $14(1)$ \\
\hline C9 & $8570(5)$ & $3959(2)$ & $6060(1)$ & $16(1)$ \\
\hline $\mathrm{C} 10$ & $8498(5)$ & $4525(2)$ & $6241(1)$ & $20(1)$ \\
\hline C11 & $8320(5)$ & $4433(2)$ & $6553(1)$ & $22(1)$ \\
\hline C12 & $8195(5)$ & $3796(2)$ & $6677(1)$ & $21(1)$ \\
\hline C13 & $8243(5)$ & $3225(2)$ & $6497(1)$ & $20(1)$ \\
\hline C14 & $8467(5)$ & $3328(2)$ & $6184(1)$ & $18(1)$ \\
\hline $\mathrm{C} 15$ & $8590(5)$ & $2827(2)$ & $5944(1)$ & $19(1)$ \\
\hline $\mathrm{C} 16$ & 2761(6) & $3783(2)$ & $4760(1)$ & $29(1)$ \\
\hline C17 & $6069(6)$ & $3717(2)$ & $4529(1)$ & $29(1)$ \\
\hline C18 & $8299(7)$ & $5031(2)$ & $6757(1)$ & $34(1)$ \\
\hline C19 & $7670(6)$ & $2488(2)$ & $6904(1)$ & $25(1)$ \\
\hline $\mathrm{C} 20$ & $7166(5)$ & $4902(2)$ & $5478(1)$ & $15(1)$ \\
\hline $\mathrm{C} 21$ & $8924(5)$ & $5150(2)$ & $5306(1)$ & $15(1)$ \\
\hline $\mathrm{C} 22$ & $10477(5)$ & $5462(2)$ & $5462(1)$ & $17(1)$ \\
\hline $\mathrm{C} 23$ & $12067(5)$ & $5718(2)$ & $5301(1)$ & $16(1)$ \\
\hline $\mathrm{C} 24$ & 13611(5) & $6072(2)$ & $5462(1)$ & $18(1)$ \\
\hline $\mathrm{C} 25$ & $15219(5)$ & $6386(2)$ & $5289(1)$ & $17(1)$ \\
\hline $\mathrm{C} 26$ & $16611(5)$ & $6755(2)$ & $5443(1)$ & $21(1)$ \\
\hline $\mathrm{C} 27$ & $18094(5)$ & $7060(2)$ & $5284(1)$ & $24(1)$ \\
\hline $\mathrm{C} 28$ & $18224(5)$ & $7002(2)$ & 4971(1) & $22(1)$ \\
\hline $\mathrm{C} 29$ & $16848(5)$ & $6623(2)$ & $4816(1)$ & $19(1)$ \\
\hline C30 & $15348(5)$ & $6294(2)$ & $4976(1)$ & $19(1)$ \\
\hline C31 & $14012(5)$ & $5807(2)$ & $4828(1)$ & $21(1)$ \\
\hline C32 & $12163(5)$ & $5659(2)$ & 4983(1) & $18(1)$ \\
\hline C33 & $10574(5)$ & $5389(2)$ & $4829(1)$ & $17(1)$ \\
\hline C34 & $8992(5)$ & $5136(2)$ & 4993(1) & $16(1)$ \\
\hline $\mathrm{C} 35$ & $18376(6)$ & $6846(2)$ & $4341(1)$ & $32(1)$ \\
\hline $\mathrm{C} 36$ & $9156(5)$ & $5083(2)$ & $4356(1)$ & $24(1)$ \\
\hline O11 & $470(20)$ & $8554(5)$ & $3284(3)$ & $45(2)$ \\
\hline $\mathrm{O} 12$ & $688(8)$ & $7432(4)$ & $3241(2)$ & $24(1)$ \\
\hline $\mathrm{C} 42$ & $98(11)$ & $7953(3)$ & $3438(1)$ & $31(2)$ \\
\hline C52 & $-2066(12)$ & $7873(5)$ & $3493(2)$ & $59(2)$ \\
\hline C53 & $1270(15)$ & $7944(4)$ & $3723(1)$ & $54(2)$ \\
\hline
\end{tabular}




\begin{tabular}{|c|c|c|c|c|}
\hline O11A & $620(50)$ & $8550(12)$ & $3283(7)$ & $43(6)$ \\
\hline O12A & $1420(30)$ & $7456(11)$ & $3261(5)$ & $39(5)$ \\
\hline $\mathrm{C} 42 \mathrm{~A}$ & $1050(30)$ & 7991(9) & 3463(4) & $46(5)$ \\
\hline C52A & $-700(40)$ & $7800(12)$ & $3653(5)$ & $75(6)$ \\
\hline C53A & $2820(40)$ & $8146(13)$ & $3647(5)$ & $85(8)$ \\
\hline $\mathrm{O} 13$ & 1836(4) & $8360(2)$ & 1530(1) & $31(1)$ \\
\hline O14 & 2819(4) & 8959(1) & 2121(1) & $27(1)$ \\
\hline O15 & $3301(4)$ & $8135(1)$ & $2456(1)$ & 21(1) \\
\hline O16 & $5036(4)$ & $5997(1)$ & $2506(1)$ & $24(1)$ \\
\hline O17 & $8258(4)$ & $5410(2)$ & 2501(1) & $28(1)$ \\
\hline $\mathrm{O} 18$ & $11707(5)$ & $4743(2)$ & $3696(1)$ & $46(1)$ \\
\hline O19 & $9196(6)$ & $5808(2)$ & $3680(1)$ & $32(1)$ \\
\hline C67 & $8757(7)$ & $5579(3)$ & $3434(1)$ & $22(1)$ \\
\hline O19A & 7937(14) & 4937(5) & $3663(2)$ & $35(2)$ \\
\hline C67A & $8174(14)$ & $5166(6)$ & $3404(2)$ & $24(3)$ \\
\hline $\mathrm{O} 20$ & $5475(4)$ & $6006(2)$ & $3746(1)$ & $36(1)$ \\
\hline C37 & $1578(5)$ & $7256(2)$ & $2726(1)$ & $20(1)$ \\
\hline C38 & $-482(6)$ & 7364(2) & 2613(1) & $23(1)$ \\
\hline C39 & $-1385(6)$ & $7943(2)$ & 2631(1) & $29(1)$ \\
\hline $\mathrm{C} 40$ & $-470(8)$ & $8562(2)$ & $2757(1)$ & $37(1)$ \\
\hline C41 & 1172(7) & $8433(2)$ & 2983(1) & $33(1)$ \\
\hline $\mathrm{C} 43$ & 1917(7) & 7711(2) & $3000(1)$ & $29(1)$ \\
\hline $\mathrm{C} 44$ & $3080(5)$ & $7419(2)$ & $2475(1)$ & $18(1)$ \\
\hline $\mathrm{C} 45$ & $2530(5)$ & $7214(2)$ & $2156(1)$ & $17(1)$ \\
\hline C46 & 2253(5) & $6592(2)$ & $2026(1)$ & $20(1)$ \\
\hline C47 & $1845(5)$ & $6560(2)$ & 1717(1) & $23(1)$ \\
\hline $\mathrm{C} 48$ & $1695(5)$ & $7145(2)$ & $1546(1)$ & $24(1)$ \\
\hline C49 & $1957(5)$ & $7768(2)$ & 1674(1) & $22(1)$ \\
\hline C50 & 2392(5) & $7795(2)$ & 1985(1) & $19(1)$ \\
\hline $\mathrm{C} 51$ & $2809(5)$ & $8371(2)$ & $2174(1)$ & $20(1)$ \\
\hline C54 & $1625(6)$ & $5894(2)$ & $1564(1)$ & $30(1)$ \\
\hline C55 & 1381(8) & $8341(3)$ & $1215(1)$ & $41(1)$ \\
\hline C56 & $1787(5)$ & $6515(2)$ & $2819(1)$ & $19(1)$ \\
\hline C57 & $3634(5)$ & $6284(2)$ & 2974(1) & $19(1)$ \\
\hline C58 & $5170(5)$ & $6004(2)$ & $2808(1)$ & $20(1)$ \\
\hline C59 & $6772(5)$ & $5726(2)$ & $2958(1)$ & $23(1)$ \\
\hline C60 & $8311(5)$ & $5409(2)$ & 2781(1) & $24(1)$ \\
\hline C61 & $9960(6)$ & $5087(2)$ & 2938(1) & $26(1)$ \\
\hline C62 & $11423(6)$ & $4816(2)$ & 2761(1) & $28(1)$ \\
\hline C63 & $12974(7)$ & $4507(2)$ & 2899(1) & $38(1)$ \\
\hline C64 & $13087(6)$ & $4465(2)$ & $3212(1)$ & $36(1)$ \\
\hline C65 & $11663(6)$ & $4751(2)$ & $3390(1)$ & $33(1)$ \\
\hline C66 & $10082(6)$ & $5092(2)$ & $3254(1)$ & $34(1)$ \\
\hline C68 & 6888(6) & $5736(2)$ & $3277(1)$ & $32(1)$ \\
\hline C69 & $5367(6)$ & $6017(2)$ & $3440(1)$ & $26(1)$ \\
\hline $\mathrm{C} 70$ & $3768(5)$ & $6277(2)$ & $3286(1)$ & $22(1)$ \\
\hline C71 & $13320(8)$ & $4419(3)$ & $3841(1)$ & $56(2)$ \\
\hline $\mathrm{C} 72$ & $3835(7)$ & $6221(3)$ & $3915(1)$ & $41(1)$ \\
\hline
\end{tabular}


Table 3. Bond lengths $[\AA]$ and angles $\left[{ }^{\circ}\right]$ for JG-IV- 113 .

\begin{tabular}{|c|c|c|c|}
\hline O1-C6 & $1.424(4)$ & C19-H19A & 0.98 \\
\hline $\mathrm{O} 1-\mathrm{C} 5$ & $1.437(4)$ & C19-H19B & 0.98 \\
\hline $\mathrm{O} 2-\mathrm{C} 7$ & $1.424(4)$ & C19-H19C & 0.98 \\
\hline $\mathrm{O} 2-\mathrm{C} 6$ & $1.433(4)$ & $\mathrm{C} 20-\mathrm{C} 21$ & $1.515(4)$ \\
\hline $\mathrm{O} 3-\mathrm{C} 13$ & $1.343(5)$ & $\mathrm{C} 20-\mathrm{H} 20 \mathrm{~A}$ & 0.99 \\
\hline O3-C19 & $1.431(4)$ & $\mathrm{C} 20-\mathrm{H} 20 \mathrm{~B}$ & 0.99 \\
\hline O4-C15 & $1.203(5)$ & C21-C34 & $1.387(5)$ \\
\hline $\mathrm{O} 5-\mathrm{C} 15$ & $1.371(4)$ & $\mathrm{C} 21-\mathrm{C} 22$ & $1.418(5)$ \\
\hline $\mathrm{O} 5-\mathrm{C} 8$ & $1.448(4)$ & $\mathrm{C} 22-\mathrm{C} 23$ & $1.402(5)$ \\
\hline $\mathrm{O} 6-\mathrm{C} 22$ & $1.338(4)$ & $\mathrm{C} 23-\mathrm{C} 32$ & $1.416(5)$ \\
\hline O6-H6 & 0.8400 & $\mathrm{C} 23-\mathrm{C} 24$ & $1.463(5)$ \\
\hline $\mathrm{O} 7-\mathrm{C} 24$ & $1.237(4)$ & $\mathrm{C} 24-\mathrm{C} 25$ & $1.485(5)$ \\
\hline $\mathrm{O} 8-\mathrm{C} 29$ & $1.346(4)$ & $\mathrm{C} 25-\mathrm{C} 26$ & $1.388(5)$ \\
\hline O8-C35 & $1.431(4)$ & $\mathrm{C} 25-\mathrm{C} 30$ & $1.404(5)$ \\
\hline O9-C31 & $1.230(5)$ & $\mathrm{C} 26-\mathrm{C} 27$ & $1.381(5)$ \\
\hline O10-C33 & $1.353(4)$ & C26-H26 & 0.95 \\
\hline O10-C36 & $1.422(4)$ & $\mathrm{C} 27-\mathrm{C} 28$ & $1.397(5)$ \\
\hline $\mathrm{C} 1-\mathrm{C} 2$ & $1.513(4)$ & $\mathrm{C} 27-\mathrm{H} 27$ & 0.95 \\
\hline $\mathrm{C} 1-\mathrm{C} 7$ & $1.542(4)$ & C28-C29 & $1.395(5)$ \\
\hline $\mathrm{C} 1-\mathrm{C} 8$ & $1.549(4)$ & C28-H28 & 0.95 \\
\hline $\mathrm{C} 1-\mathrm{C} 20$ & $1.558(5)$ & C29-C30 & $1.414(5)$ \\
\hline $\mathrm{C} 2-\mathrm{C} 3$ & $1.317(5)$ & C30-C31 & $1.494(5)$ \\
\hline $\mathrm{C} 2-\mathrm{H} 2$ & 0.95 & C31-C32 & $1.477(5)$ \\
\hline C3-C4 & $1.505(5)$ & C32-C33 & $1.398(5)$ \\
\hline C3-H3 & 0.95 & C33-C34 & $1.404(5)$ \\
\hline C4-C5 & $1.527(5)$ & C34-H34 & 0.95 \\
\hline C4-H4A & 0.99 & C35-H35A & 0.98 \\
\hline C4-H4B & 0.99 & C35-H35B & 0.98 \\
\hline $\mathrm{C} 5-\mathrm{C} 7$ & $1.537(5)$ & C35-H35C & 0.98 \\
\hline C5-H5 & 1.00 & C36-H36A & 0.98 \\
\hline C6-C16 & $1.506(5)$ & C36-H36B & 0.98 \\
\hline C6-C17 & $1.511(5)$ & $\mathrm{C} 36-\mathrm{H} 36 \mathrm{C}$ & 0.98 \\
\hline $\mathrm{C} 7-\mathrm{H} 7$ & 1.00 & $\mathrm{O} 11-\mathrm{C} 42$ & $1.407(8)$ \\
\hline C8-C9 & $1.519(4)$ & O11-C41 & $1.441(15)$ \\
\hline C8-H8 & 1.00 & $\mathrm{O} 12-\mathrm{C} 42$ & $1.419(7)$ \\
\hline C9-C14 & $1.380(5)$ & $\mathrm{O} 12-\mathrm{C} 43$ & $1.473(9)$ \\
\hline C9-C10 & $1.391(5)$ & C42-C53 & $1.499(10)$ \\
\hline C10-C11 & $1.401(5)$ & C42-C52 & $1.517(11)$ \\
\hline C10-H10 & 0.95 & $\mathrm{C} 52-\mathrm{H} 52 \mathrm{~A}$ & 0.98 \\
\hline $\mathrm{C} 11-\mathrm{C} 12$ & $1.392(5)$ & C52-H52B & 0.98 \\
\hline C11-C18 & $1.502(5)$ & C52-H52C & 0.98 \\
\hline C12-C13 & $1.394(5)$ & C53-H53A & 0.98 \\
\hline C12-H12 & 0.95 & C53-H53B & 0.98 \\
\hline C13-C14 & $1.411(5)$ & C53-H53C & 0.98 \\
\hline C14-C15 & $1.468(5)$ & O11A-C42A & $1.408(12)$ \\
\hline C16-H16A & 0.98 & O11A-C41 & $1.40(4)$ \\
\hline C16-H16B & 0.98 & $\mathrm{O} 12 \mathrm{~A}-\mathrm{C} 43$ & $1.31(2)$ \\
\hline C16-H16C & 0.98 & O12A-C42A & $1.418(12)$ \\
\hline C17-H17A & 0.98 & C42A-C53A & $1.500(15)$ \\
\hline C17-H17B & 0.98 & $\mathrm{C} 42 \mathrm{~A}-\mathrm{C} 52 \mathrm{~A}$ & $1.518(16)$ \\
\hline $\mathrm{C} 17-\mathrm{H} 17 \mathrm{C}$ & 0.98 & C52A-H52D & 0.98 \\
\hline C18-H18A & 0.98 & C52A-H52E & 0.98 \\
\hline C18-H18B & 0.98 & C52A-H52F & 0.98 \\
\hline C18-H18C & 0.98 & C53A-H53D & 0.98 \\
\hline
\end{tabular}




\begin{tabular}{|c|c|c|c|}
\hline C53A-H53E & 0.98 & C47-C48 & $1.400(6)$ \\
\hline C53A-H53F & 0.98 & C47-C54 & $1.504(5)$ \\
\hline O13-C49 & $1.352(5)$ & C48-C49 & $1.383(6)$ \\
\hline O13-C55 & $1.431(5)$ & C48-H48 & 0.95 \\
\hline O14-C51 & $1.200(5)$ & C49-C50 & $1.410(5)$ \\
\hline O15-C51 & $1.379(4)$ & C50-C51 & $1.453(5)$ \\
\hline $\mathrm{O} 15-\mathrm{C} 44$ & $1.445(4)$ & C54-H54A & 0.98 \\
\hline O16-C58 & $1.347(4)$ & C54-H54B & 0.98 \\
\hline O16-H16 & 0.8400 & C54-H54C & 0.98 \\
\hline O17-C60 & $1.244(5)$ & C55-H55A & 0.98 \\
\hline O18-C65 & $1.353(5)$ & C55-H55B & 0.98 \\
\hline O18-C71 & $1.439(5)$ & C55-H55C & 0.98 \\
\hline O19-C67 & $1.219(6)$ & C56-C57 & $1.516(5)$ \\
\hline C67-C68 & $1.496(5)$ & C56-H56A & 0.99 \\
\hline C67-C66 & $1.555(6)$ & C56-H56B & 0.99 \\
\hline O19A-C67A & $1.247(12)$ & C57-C70 & $1.386(5)$ \\
\hline C67A-C66 & $1.479(9)$ & C57-C58 & $1.404(5)$ \\
\hline C67A-C68 & $1.551(9)$ & C58-C59 & $1.402(5)$ \\
\hline O20-C69 & $1.359(4)$ & C59-C68 & $1.415(5)$ \\
\hline $\mathrm{O} 20-\mathrm{C} 72$ & $1.422(5)$ & C59-C60 & $1.463(6)$ \\
\hline C37-C38 & $1.518(5)$ & C60-C61 & $1.478(5)$ \\
\hline C37-C43 & $1.537(5)$ & C61-C62 & $1.384(6)$ \\
\hline C37-C56 & $1.548(5)$ & C61-C66 & $1.404(6)$ \\
\hline C37-C44 & $1.555(5)$ & C62-C63 & $1.376(6)$ \\
\hline C38-C39 & $1.317(6)$ & C62-H62 & 0.95 \\
\hline C38-H38 & 0.95 & C63-C64 & $1.389(7)$ \\
\hline C39-C40 & $1.498(7)$ & C63-H63 & 0.95 \\
\hline C39-H39 & 0.95 & C64-C65 & $1.385(7)$ \\
\hline $\mathrm{C} 40-\mathrm{C} 41$ & $1.532(7)$ & C64-H64 & 0.95 \\
\hline $\mathrm{C} 40-\mathrm{H} 40 \mathrm{~A}$ & 0.99 & C65-C66 & $1.420(5)$ \\
\hline C40-H40B & 0.99 & C68-C69 & $1.390(6)$ \\
\hline C41-C43 & $1.536(6)$ & C69-C70 & $1.394(5)$ \\
\hline C41-H41 & 1.00 & $\mathrm{C} 70-\mathrm{H} 70$ & 0.95 \\
\hline $\mathrm{C} 43-\mathrm{H} 43$ & 1.00 & C71-H71A & 0.98 \\
\hline C44-C45 & $1.519(5)$ & C71-H71B & 0.98 \\
\hline C44-H44 & 1.00 & C71-H71C & 0.98 \\
\hline $\mathrm{C} 45-\mathrm{C} 46$ & $1.387(5)$ & $\mathrm{C} 72-\mathrm{H} 72 \mathrm{~A}$ & 0.98 \\
\hline C45-C50 & $1.392(5)$ & C72-H72B & 0.98 \\
\hline C46-C47 & $1.398(5)$ & $\mathrm{C} 72-\mathrm{H} 72 \mathrm{C}$ & 0.98 \\
\hline C46-H46 & 0.95 & & \\
\hline $\mathrm{C} 6-\mathrm{O} 1-\mathrm{C} 5$ & $109.8(3)$ & $\mathrm{C} 1-\mathrm{C} 2-\mathrm{H} 2$ & 118.5 \\
\hline $\mathrm{C} 7-\mathrm{O} 2-\mathrm{C} 6$ & $107.6(3)$ & $\mathrm{C} 2-\mathrm{C} 3-\mathrm{C} 4$ & $124.8(3)$ \\
\hline C13-O3-C19 & $116.9(3)$ & $\mathrm{C} 2-\mathrm{C} 3-\mathrm{H} 3$ & 117.6 \\
\hline $\mathrm{C} 15-\mathrm{O} 5-\mathrm{C} 8$ & $111.7(3)$ & $\mathrm{C} 4-\mathrm{C} 3-\mathrm{H} 3$ & 117.6 \\
\hline C22-O6-H6 & 109.5 & $\mathrm{C} 3-\mathrm{C} 4-\mathrm{C} 5$ & $114.9(3)$ \\
\hline $\mathrm{C} 29-\mathrm{O} 8-\mathrm{C} 35$ & $119.2(3)$ & $\mathrm{C} 3-\mathrm{C} 4-\mathrm{H} 4 \mathrm{~A}$ & 108.5 \\
\hline C33-O10-C36 & $119.2(3)$ & $\mathrm{C} 5-\mathrm{C} 4-\mathrm{H} 4 \mathrm{~A}$ & 108.5 \\
\hline $\mathrm{C} 2-\mathrm{C} 1-\mathrm{C} 7$ & $109.2(3)$ & C3-C4-H4B & 108.5 \\
\hline $\mathrm{C} 2-\mathrm{C} 1-\mathrm{C} 8$ & 110.1(3) & C5-C4-H4B & 108.5 \\
\hline $\mathrm{C} 7-\mathrm{C} 1-\mathrm{C} 8$ & $109.4(3)$ & $\mathrm{H} 4 \mathrm{~A}-\mathrm{C} 4-\mathrm{H} 4 \mathrm{~B}$ & 107.5 \\
\hline $\mathrm{C} 2-\mathrm{C} 1-\mathrm{C} 20$ & $108.2(3)$ & $\mathrm{O} 1-\mathrm{C} 5-\mathrm{C} 4$ & $110.8(3)$ \\
\hline $\mathrm{C} 7-\mathrm{C} 1-\mathrm{C} 20$ & $110.0(3)$ & $\mathrm{O} 1-\mathrm{C} 5-\mathrm{C} 7$ & $102.4(3)$ \\
\hline $\mathrm{C} 8-\mathrm{C} 1-\mathrm{C} 20$ & $109.9(3)$ & $\mathrm{C} 4-\mathrm{C} 5-\mathrm{C} 7$ & 116.1(3) \\
\hline $\mathrm{C} 3-\mathrm{C} 2-\mathrm{C} 1$ & $123.1(3)$ & $\mathrm{O} 1-\mathrm{C} 5-\mathrm{H} 5$ & 109.1 \\
\hline $\mathrm{C} 3-\mathrm{C} 2-\mathrm{H} 2$ & 118.5 & $\mathrm{C} 4-\mathrm{C} 5-\mathrm{H} 5$ & 109.1 \\
\hline
\end{tabular}




\begin{tabular}{|c|c|}
\hline C7-C5-H5 & 109.1 \\
\hline O1-C6-O2 & 106.1(3) \\
\hline O1-C6-C16 & $111.5(3)$ \\
\hline $\mathrm{O} 2-\mathrm{C} 6-\mathrm{C} 16$ & $107.9(3)$ \\
\hline O1-C6-C17 & $108.2(3)$ \\
\hline O2-C6-C17 & 111.2(3) \\
\hline C16-C6-C17 & $111.8(3)$ \\
\hline $\mathrm{O} 2-\mathrm{C} 7-\mathrm{C} 5$ & $102.6(3)$ \\
\hline $\mathrm{O} 2-\mathrm{C} 7-\mathrm{C} 1$ & $107.5(3)$ \\
\hline $\mathrm{C} 5-\mathrm{C} 7-\mathrm{C} 1$ & 117.7(3) \\
\hline $\mathrm{O} 2-\mathrm{C} 7-\mathrm{H} 7$ & 109.5 \\
\hline C5-C7-H7 & 109.5 \\
\hline C1-C7-H7 & 109.5 \\
\hline O5-C8-C9 & $103.5(3)$ \\
\hline O5-C8-C1 & 108.6(3) \\
\hline C9-C8-C1 & $116.4(3)$ \\
\hline O5-C8-H8 & 109.3 \\
\hline C9-C8-H8 & 109.3 \\
\hline C1-C8-H8 & 109.3 \\
\hline C14-C9-C10 & $121.0(3)$ \\
\hline C14-C9-C8 & 107.7(3) \\
\hline $\mathrm{C} 10-\mathrm{C} 9-\mathrm{C} 8$ & $131.3(3)$ \\
\hline C9-C10-C11 & $117.7(3)$ \\
\hline C9-C10-H10 & 121.1 \\
\hline C11-C10-H10 & 121.1 \\
\hline C12-C11-C10 & 121.1(3) \\
\hline C12-C11-C18 & $119.5(3)$ \\
\hline C10-C11-C18 & 119.4(4) \\
\hline C11-C12-C13 & 121.6(3) \\
\hline C11-C12-H12 & 119.2 \\
\hline C13-C12-H12 & 119.2 \\
\hline $\mathrm{O} 3-\mathrm{C} 13-\mathrm{C} 12$ & $126.6(3)$ \\
\hline O3-C13-C14 & $117.0(3)$ \\
\hline C12-C13-C14 & $116.5(3)$ \\
\hline C9-C14-C13 & 122.1(3) \\
\hline C9-C14-C15 & 109.4(3) \\
\hline C13-C14-C15 & $128.4(3)$ \\
\hline $\mathrm{O} 4-\mathrm{C} 15-\mathrm{O} 5$ & $121.0(3)$ \\
\hline O4-C15-C14 & $132.0(3)$ \\
\hline $\mathrm{O} 5-\mathrm{C} 15-\mathrm{C} 14$ & 107.1(3) \\
\hline C6-C16-H16A & 109.5 \\
\hline C6-C16-H16B & 109.5 \\
\hline H16A-C16-H16B & 109.5 \\
\hline C6-C16-H16C & 109.5 \\
\hline H16A-C16-H16C & 109.5 \\
\hline H16B-C16-H16C & 109.5 \\
\hline C6-C17-H17A & 109.5 \\
\hline C6-C17-H17B & 109.5 \\
\hline H17A-C17-H17B & 109.5 \\
\hline C6-C17-H17C & 109.5 \\
\hline H17A-C17-H17C & 109.5 \\
\hline H17B-C17-H17C & 109.5 \\
\hline C11-C18-H18A & 109.5 \\
\hline C11-C18-H18B & 109.5 \\
\hline H18A-C18-H18B & 109.5 \\
\hline C11-C18-H18C & 109.5 \\
\hline
\end{tabular}

\begin{tabular}{|c|c|}
\hline H18A-C18-H18C & 109.5 \\
\hline H18B-C18-H18C & 109.5 \\
\hline O3-C19-H19A & 109.5 \\
\hline O3-C19-H19B & 109.5 \\
\hline H19A-C19-H19B & 109.5 \\
\hline O3-C19-H19C & 109.5 \\
\hline H19A-C19-H19C & 109.5 \\
\hline H19B-C19-H19C & 109.5 \\
\hline $\mathrm{C} 21-\mathrm{C} 20-\mathrm{C} 1$ & $118.4(3)$ \\
\hline $\mathrm{C} 21-\mathrm{C} 20-\mathrm{H} 20 \mathrm{~A}$ & 107.7 \\
\hline $\mathrm{C} 1-\mathrm{C} 20-\mathrm{H} 20 \mathrm{~A}$ & 107.7 \\
\hline С21-C20-H20B & 107.7 \\
\hline C1-C20-H20B & 107.7 \\
\hline $\mathrm{H} 20 \mathrm{~A}-\mathrm{C} 20-\mathrm{H} 20 \mathrm{~B}$ & 107.1 \\
\hline C34-C21-C22 & $118.2(3)$ \\
\hline C34-C21-C20 & $121.6(3)$ \\
\hline C22-C21-C20 & $119.9(3)$ \\
\hline O6-C22-C23 & $121.9(3)$ \\
\hline O6-C22-C21 & $118.2(3)$ \\
\hline C23-C22-C21 & $120.0(3)$ \\
\hline $\mathrm{C} 22-\mathrm{C} 23-\mathrm{C} 32$ & $120.8(3)$ \\
\hline C22-C23-C24 & $119.7(3)$ \\
\hline C32-C23-C24 & $119.5(3)$ \\
\hline $\mathrm{O} 7-\mathrm{C} 24-\mathrm{C} 23$ & $121.4(3)$ \\
\hline O7-C24-C25 & $119.0(3)$ \\
\hline $\mathrm{C} 23-\mathrm{C} 24-\mathrm{C} 25$ & $119.6(3)$ \\
\hline $\mathrm{C} 26-\mathrm{C} 25-\mathrm{C} 30$ & $120.8(3)$ \\
\hline $\mathrm{C} 26-\mathrm{C} 25-\mathrm{C} 24$ & $119.0(3)$ \\
\hline $\mathrm{C} 30-\mathrm{C} 25-\mathrm{C} 24$ & $120.1(3)$ \\
\hline $\mathrm{C} 27-\mathrm{C} 26-\mathrm{C} 25$ & $119.6(3)$ \\
\hline C27-C26-H26 & 120.2 \\
\hline $\mathrm{C} 25-\mathrm{C} 26-\mathrm{H} 26$ & 120.2 \\
\hline C26-C27-C28 & $121.2(3)$ \\
\hline $\mathrm{C} 26-\mathrm{C} 27-\mathrm{H} 27$ & 119.4 \\
\hline $\mathrm{C} 28-\mathrm{C} 27-\mathrm{H} 27$ & 119.4 \\
\hline $\mathrm{C} 29-\mathrm{C} 28-\mathrm{C} 27$ & $119.5(3)$ \\
\hline $\mathrm{C} 29-\mathrm{C} 28-\mathrm{H} 28$ & 120.3 \\
\hline $\mathrm{C} 27-\mathrm{C} 28-\mathrm{H} 28$ & 120.3 \\
\hline O8-C29-C28 & $123.3(3)$ \\
\hline O8-C29-C30 & $116.6(3)$ \\
\hline C28-C29-C30 & $120.0(3)$ \\
\hline C25-C30-C29 & $118.8(3)$ \\
\hline C25-C30-C31 & $118.9(3)$ \\
\hline C29-C30-C31 & $122.1(3)$ \\
\hline O9-C31-C32 & $121.9(3)$ \\
\hline $\mathrm{O} 9-\mathrm{C} 31-\mathrm{C} 30$ & $120.9(3)$ \\
\hline C32-C31-C30 & $117.1(3)$ \\
\hline C33-C32-C23 & $118.9(3)$ \\
\hline C33-C32-C31 & $121.4(3)$ \\
\hline C23-C32-C31 & $119.2(3)$ \\
\hline O10-C33-C32 & $116.9(3)$ \\
\hline O10-C33-C34 & $123.7(3)$ \\
\hline C32-C33-C34 & $119.4(3)$ \\
\hline C21-C34-C33 & $122.4(3)$ \\
\hline C21-C34-H34 & 118.8 \\
\hline C33-C34-H34 & 118.8 \\
\hline
\end{tabular}




\begin{tabular}{|c|c|c|c|}
\hline O8-C35-H35A & 109.5 & O19-C67-C68 & $123.4(5)$ \\
\hline O8-C35-H35B & 109.5 & O19-C67-C66 & $123.4(4)$ \\
\hline H35A-C35-H35B & 109.5 & C68-C67-C66 & $113.3(4)$ \\
\hline $\mathrm{O} 8-\mathrm{C} 35-\mathrm{H} 35 \mathrm{C}$ & 109.5 & O19A-C67A-C66 & $119.6(7)$ \\
\hline H35A-C35-H35C & 109.5 & O19A-C67A-C68 & $122.2(7)$ \\
\hline H35B-C $35-H 35 C$ & 109.5 & C66-C67A-C68 & $114.5(7)$ \\
\hline O10-C36-H36A & 109.5 & C69-O20-C72 & $118.7(3)$ \\
\hline O10-C36-H36B & 109.5 & C38-C37-C43 & $108.6(3)$ \\
\hline H36A-C36-H36B & 109.5 & C38-C37-C56 & $108.2(3)$ \\
\hline O10-C36-H36C & 109.5 & C43-C37-C56 & $110.1(3)$ \\
\hline H36A-C36-H36C & 109.5 & C38-C37-C44 & $110.6(3)$ \\
\hline H36B-C36-H36C & 109.5 & C43-C37-C44 & $110.0(3)$ \\
\hline C42-O11-C41 & $111.5(9)$ & C56-C37-C44 & $109.3(3)$ \\
\hline C42-O12-C43 & $109.3(6)$ & C39-C38-C37 & $123.0(4)$ \\
\hline $\mathrm{O} 11-\mathrm{C} 42-\mathrm{O} 12$ & 106.3(6) & C39-C38-H38 & 118.5 \\
\hline O11-C42-C53 & $108.8(8)$ & C37-C38-H38 & 118.5 \\
\hline $\mathrm{O} 12-\mathrm{C} 42-\mathrm{C} 53$ & $110.8(6)$ & C38-C39-C40 & $123.6(4)$ \\
\hline O11-C42-C52 & $110.3(8)$ & C38-C39-H39 & 118.2 \\
\hline O12-C42-C52 & $107.5(7)$ & C40-C39-H39 & 118.2 \\
\hline C53-C42-C52 & $113.0(7)$ & C39-C40-C41 & $114.5(3)$ \\
\hline C42-C52-H52A & 109.5 & C39-C40-H40A & 108.6 \\
\hline C42-C52-H52B & 109.5 & C41-C40-H40A & 108.6 \\
\hline H52A-C52-H52B & 109.5 & C39-C40-H40B & 108.6 \\
\hline C42-C52-H52C & 109.5 & $\mathrm{C} 41-\mathrm{C} 40-\mathrm{H} 40 \mathrm{~B}$ & 108.6 \\
\hline $\mathrm{H} 52 \mathrm{~A}-\mathrm{C} 52-\mathrm{H} 52 \mathrm{C}$ & 109.5 & H40A-C40-H40B & 107.6 \\
\hline $\mathrm{H} 52 \mathrm{~B}-\mathrm{C} 52-\mathrm{H} 52 \mathrm{C}$ & 109.5 & O11A-C41-C40 & $113.0(14)$ \\
\hline C42-C53-H53A & 109.5 & O11-C41-C40 & $109.3(7)$ \\
\hline C42-C53-H53B & 109.5 & O11A-C41-C43 & $101.5(9)$ \\
\hline H53A-C53-H53B & 109.5 & O11-C41-C43 & $102.9(5)$ \\
\hline C42-C53-H53C & 109.5 & C40-C41-C43 & $115.9(4)$ \\
\hline H53A-C53-H53C & 109.5 & O11-C41-H41 & 109.5 \\
\hline H53B-C53-H53C & 109.5 & $\mathrm{C} 40-\mathrm{C} 41-\mathrm{H} 41$ & 109.5 \\
\hline C42A-O11A-C41 & $110(2)$ & C43-C41-H41 & 109.5 \\
\hline $\mathrm{C} 43-\mathrm{O} 12 \mathrm{~A}-\mathrm{C} 42 \mathrm{~A}$ & $108.0(17)$ & $\mathrm{O} 12 \mathrm{~A}-\mathrm{C} 43-\mathrm{C} 37$ & $115.3(8)$ \\
\hline O11A-C42A-O12A & $106.3(14)$ & O12-C43-C37 & $105.2(4)$ \\
\hline O11A-C42A-C53A & $108.5(15)$ & O12A-C43-C41 & $108.9(9)$ \\
\hline O12A-C42A-C53A & $110.8(15)$ & O12-C43-C41 & $101.7(4)$ \\
\hline O11A-C42A-C52A & $110.3(16)$ & C37-C43-C41 & $117.9(3)$ \\
\hline $\mathrm{O} 12 \mathrm{~A}-\mathrm{C} 42 \mathrm{~A}-\mathrm{C} 52 \mathrm{~A}$ & $107.5(14)$ & $\mathrm{O} 12-\mathrm{C} 43-\mathrm{H} 43$ & 110.5 \\
\hline C53A-C42A-C52A & $113.3(15)$ & $\mathrm{C} 37-\mathrm{C} 43-\mathrm{H} 43$ & 110.5 \\
\hline C42A-C52A-H52D & 109.5 & C41-C43-H43 & 110.5 \\
\hline C42A-C52A-H52E & 109.5 & O15-C44-C45 & $103.9(3)$ \\
\hline H52D-C52A-H52E & 109.5 & O15-C44-C37 & $108.7(3)$ \\
\hline C42A-C52A-H52F & 109.5 & C45-C44-C37 & $116.4(3)$ \\
\hline H52D-C52A-H52F & 109.5 & O15-C44-H44 & 109.2 \\
\hline H52E-C52A-H52F & 109.5 & $\mathrm{C} 45-\mathrm{C} 44-\mathrm{H} 44$ & 109.2 \\
\hline C42A-C53A-H53D & 109.5 & C37-C44-H44 & 109.2 \\
\hline C42A-C53A-H53E & 109.5 & $\mathrm{C} 46-\mathrm{C} 45-\mathrm{C} 50$ & $120.9(3)$ \\
\hline H53D-C53A-H53E & 109.5 & C46-C45-C44 & $131.7(3)$ \\
\hline C42A-C53A-H53F & 109.5 & $\mathrm{C} 50-\mathrm{C} 45-\mathrm{C} 44$ & $107.3(3)$ \\
\hline H53D-C53A-H53F & 109.5 & C45-C46-C47 & $118.5(3)$ \\
\hline H53E-C53A-H53F & 109.5 & C45-C46-H46 & 120.7 \\
\hline C49-O13-C55 & $116.9(4)$ & C47-C46-H46 & 120.7 \\
\hline C51-O15-C44 & $111.5(3)$ & $\mathrm{C} 48-\mathrm{C} 47-\mathrm{C} 46$ & $120.4(4)$ \\
\hline C58-O16-H16 & 109.5 & C48-C47-C54 & $119.4(3)$ \\
\hline C65-O18-C71 & $118.1(4)$ & C46-C47-C54 & $120.2(4)$ \\
\hline
\end{tabular}




$\begin{array}{ll}\text { C49-C48-C47 } & 121.5(3) \\ \text { C49-C48-H48 } & 119.3 \\ \text { C47-C48-H48 } & 119.3 \\ \text { O13-C49-C48 } & 126.0(3) \\ \text { O13-C49-C50 } & 116.3(3) \\ \text { C48-C49-C50 } & 117.7(3) \\ \text { C45-C50-C49 } & 120.9(3) \\ \text { C45-C50-C51 } & 109.6(3) \\ \text { C49-C50-C51 } & 129.4(3) \\ \text { O14-C51-O15 } & 120.7(3) \\ \text { O14-C51-C50 } & 131.9(3) \\ \text { O15-C51-C50 } & 107.4(3) \\ \text { C47-C54-H54A } & 109.5 \\ \text { C47-C54-H54B } & 109.5 \\ \text { H54A-C54-H54B } & 109.5 \\ \text { C47-C54-H54C } & 109.5 \\ \text { H54A-C54-H54C } & 109.5 \\ \text { H54B-C54-H54C } & 109.5 \\ \text { O13-C55-H55A } & 109.5 \\ \text { O13-C55-H55B } & 109.5 \\ \text { H55A-C55-H55B } & 109.5 \\ \text { O13-C55-H55C } & 109.5 \\ \text { H55A-C55-H55C } & 109.5 \\ \text { H55B-C55-H55C } & 109.5 \\ \text { C57-C56-C37 } & 119.4(3) \\ \text { C57-C56-H56A } & 107.5 \\ \text { C37-C56-H56A } & 107.5 \\ \text { C57-C56-H56B } & 107.5 \\ \text { C37-C56-H56B } & 107.5 \\ \text { H56A-C56-H56B } & 107.0 \\ \text { C70-C57-C58 } & 117.9(3) \\ \text { C70-C57-C56 } & 120.7(3) \\ \text { C58-C57-C56 } & 121.0(3) \\ \text { O16-C58-C59 } & 121.5(3) \\ \text { O16-C58-C57 } & 118.3(3) \\ \text { C59-C58-C57 } & 120.1(3) \\ \text { C58-C59-C68 } & 120.8(4) \\ \text { C58-C59-C60 } & 119.1(3) \\ \text { C68-C59-C60 } & 120.1(3) \\ \text { O17-C60-C59 } & 121.0(3) \\ \text { O17-C60-C61 } & 119.5(4) \\ \text { C59-C60-C61 } & 119.5(3) \\ \text { C62-C61-C66 } & 121.6(4) \\ & \end{array}$

$\begin{array}{ll}\text { C62-C61-C60 } & 117.6(4) \\ \text { C66-C61-C60 } & 120.7(4) \\ \text { C63-C62-C61 } & 119.2(4) \\ \text { C63-C62-H62 } & 120.4 \\ \text { C61-C62-H62 } & 120.4 \\ \text { C62-C63-C64 } & 120.9(4) \\ \text { C62-C63-H63 } & 119.6 \\ \text { C64-C63-H63 } & 119.6 \\ \text { C65-C64-C63 } & 120.4(4) \\ \text { C65-C64-H64 } & 119.8 \\ \text { C63-C64-H64 } & 119.8 \\ \text { O18-C65-C64 } & 123.5(4) \\ \text { O18-C65-C66 } & 116.7(4) \\ \text { C64-C65-C66 } & 119.8(4) \\ \text { C61-C66-C65 } & 117.9(4) \\ \text { C61-C66-C67A } & 113.5(5) \\ \text { C65-C66-C67A } & 122.3(5) \\ \text { C61-C66-C67 } & 118.9(4) \\ \text { C65-C66-C67 } & 122.0(4) \\ \text { C69-C68-C59 } & 118.8(3) \\ \text { C69-C68-C67 } & 119.3(4) \\ \text { C59-C68-C67 } & 120.8(4) \\ \text { C69-C68-C67A } & 122.6(5) \\ \text { C59-C68-C67A } & 112.7(5) \\ \text { O20-C69-C68 } & 118.1(3) \\ \text { O20-C69-C70 } & 122.5(4) \\ \text { C68-C69-C70 } & 119.4(3) \\ \text { C57-C70-C69 } & 122.9(4) \\ \text { C57-C70-H70 } & 118.5 \\ \text { C69-C70-H70 } & 118.5 \\ \text { O18-C71-H71A } & 109.5 \\ \text { O18-C71-H71B } & 109.5 \\ \text { H71A-C71-H71B } & 109.5 \\ \text { O18-C71-H71C } & 109.5 \\ \text { H71A-C71-H71C } & 109.5 \\ \text { H71B-C71-H71C } & 109.5 \\ \text { O20-C72-H72A } & 109.5 \\ \text { O20-C72-H72B } & 109.5 \\ \text { H72A-C72-H72B } & 109.5 \\ \text { O20-C72-H72C } & 109.5 \\ \text { H72A-C72-H72C } & 109.5 \\ \text { H72B-C72-H72C } & 109.5 \\ & \end{array}$


Table 4. Anisotropic displacement parameters $\left(\AA^{2} \times 10^{3}\right)$ for JG-IV-113. The anisotropic displacement factor exponent takes the form: $\quad-2 \pi^{2}\left[\mathrm{~h}^{2} \mathrm{a}^{* 2} \mathrm{U}^{11}+\ldots \quad+2 \mathrm{~h} \mathrm{k} \mathrm{a}^{*} \mathrm{~b}^{*} \mathrm{U}^{12}\right]$

\begin{tabular}{|c|c|c|c|c|c|c|}
\hline & $\mathrm{U}^{11}$ & $\mathrm{U}^{22}$ & $\mathrm{U}^{33}$ & $\mathrm{U}^{23}$ & $\mathrm{U}^{13}$ & $\mathrm{U}^{12}$ \\
\hline$\overline{\mathrm{O} 1}$ & $42(2)$ & $16(1)$ & $26(1)$ & $-1(1)$ & $-11(1)$ & $-5(1)$ \\
\hline $\mathrm{O} 2$ & 21(1) & $14(1)$ & $16(1)$ & $-1(1)$ & $-4(1)$ & $0(1)$ \\
\hline $\mathrm{O} 3$ & $25(1)$ & $25(1)$ & $20(1)$ & $8(1)$ & $5(1)$ & $6(1)$ \\
\hline $\mathrm{O} 4$ & $44(2)$ & $16(1)$ & $26(1)$ & $3(1)$ & $6(1)$ & $6(1)$ \\
\hline O5 & $20(1)$ & $18(1)$ & $17(1)$ & $2(1)$ & $3(1)$ & $5(1)$ \\
\hline O6 & $25(1)$ & $33(2)$ & $14(1)$ & $-3(1)$ & $0(1)$ & $-11(1)$ \\
\hline $\mathrm{O} 7$ & $26(1)$ & $37(2)$ & $15(1)$ & $-4(1)$ & $0(1)$ & $-10(1)$ \\
\hline O8 & $29(1)$ & $35(2)$ & $18(1)$ & $2(1)$ & $5(1)$ & $-14(1)$ \\
\hline O9 & $24(1)$ & $32(2)$ & $21(1)$ & $-4(1)$ & $4(1)$ & $-3(1)$ \\
\hline O10 & $20(1)$ & $34(2)$ & $15(1)$ & 1(1) & $-1(1)$ & $-9(1)$ \\
\hline $\mathrm{C} 1$ & $16(2)$ & $19(2)$ & $12(1)$ & 1(1) & $1(1)$ & $-1(1)$ \\
\hline $\mathrm{C} 2$ & $18(2)$ & $22(2)$ & $16(2)$ & $2(1)$ & 2(1) & $2(1)$ \\
\hline $\mathrm{C} 3$ & $16(2)$ & $24(2)$ & $22(2)$ & $8(1)$ & $0(1)$ & $2(1)$ \\
\hline C4 & $29(2)$ & $21(2)$ & $30(2)$ & $1(2)$ & $2(2)$ & $-7(2)$ \\
\hline $\mathrm{C} 5$ & $24(2)$ & $13(2)$ & $24(2)$ & 1(1) & $-7(1)$ & 1(1) \\
\hline C6 & $23(2)$ & $17(2)$ & $21(2)$ & $-2(1)$ & $-5(1)$ & $-2(1)$ \\
\hline C7 & $16(2)$ & $17(2)$ & $13(1)$ & $0(1)$ & $-4(1)$ & 1(1) \\
\hline C8 & $15(1)$ & $14(2)$ & $15(2)$ & 1(1) & 1(1) & 1(1) \\
\hline C9 & $13(2)$ & $21(2)$ & $14(2)$ & $2(1)$ & $-1(1)$ & $-1(1)$ \\
\hline C10 & $21(2)$ & $18(2)$ & $20(2)$ & 1(1) & $0(1)$ & $1(1)$ \\
\hline C11 & $22(2)$ & $25(2)$ & $20(2)$ & $-1(1)$ & $0(1)$ & $-1(1)$ \\
\hline C12 & $20(2)$ & $30(2)$ & $13(2)$ & $3(1)$ & $0(1)$ & $1(2)$ \\
\hline C13 & $16(2)$ & $23(2)$ & $20(2)$ & $4(1)$ & 1(1) & $4(1)$ \\
\hline C14 & $15(2)$ & $20(2)$ & $17(2)$ & 1(1) & $2(1)$ & $7(1)$ \\
\hline C15 & $19(2)$ & $19(2)$ & $19(2)$ & $4(1)$ & 2(1) & $6(1)$ \\
\hline C16 & $25(2)$ & $24(2)$ & $39(2)$ & $-4(2)$ & $-7(2)$ & $-1(2)$ \\
\hline C17 & $31(2)$ & $33(2)$ & $24(2)$ & $-7(2)$ & $0(2)$ & $-7(2)$ \\
\hline C18 & $46(2)$ & $34(2)$ & $20(2)$ & $-5(2)$ & $2(2)$ & $1(2)$ \\
\hline C19 & $22(2)$ & $32(2)$ & $21(2)$ & $11(2)$ & 2(1) & $4(2)$ \\
\hline $\mathrm{C} 20$ & $16(2)$ & $15(2)$ & $15(2)$ & $-2(1)$ & $2(1)$ & 1(1) \\
\hline C21 & $15(2)$ & $12(2)$ & $19(2)$ & $2(1)$ & $0(1)$ & $3(1)$ \\
\hline $\mathrm{C} 22$ & $20(2)$ & $15(2)$ & $14(2)$ & $-2(1)$ & $-1(1)$ & $1(1)$ \\
\hline C23 & $17(2)$ & $14(2)$ & $16(2)$ & $-1(1)$ & 1(1) & $-1(1)$ \\
\hline C24 & $19(2)$ & $20(2)$ & $17(2)$ & $-1(1)$ & $-1(1)$ & $1(1)$ \\
\hline $\mathrm{C} 25$ & $14(2)$ & $14(2)$ & $21(2)$ & 1(1) & $-1(1)$ & 2(1) \\
\hline C26 & $23(2)$ & $23(2)$ & $18(2)$ & $0(1)$ & $-3(1)$ & $0(1)$ \\
\hline $\mathrm{C} 27$ & $21(2)$ & $21(2)$ & $31(2)$ & $3(2)$ & $-6(1)$ & $-6(1)$ \\
\hline C28 & $17(2)$ & $19(2)$ & $29(2)$ & $3(1)$ & $1(1)$ & $-5(1)$ \\
\hline C29 & $19(2)$ & $19(2)$ & $19(2)$ & 2(1) & $0(1)$ & $-1(1)$ \\
\hline C30 & $16(2)$ & $20(2)$ & $21(2)$ & 2(1) & $0(1)$ & 1(1) \\
\hline C31 & $21(2)$ & $22(2)$ & $21(2)$ & $5(1)$ & 1(1) & $4(1)$ \\
\hline C32 & $17(2)$ & $22(2)$ & $17(2)$ & 1(1) & $0(1)$ & $-2(1)$ \\
\hline C33 & $19(2)$ & $19(2)$ & $13(2)$ & 1(1) & $-2(1)$ & $-2(1)$ \\
\hline C34 & $14(1)$ & $16(2)$ & $17(2)$ & $0(1)$ & $-2(1)$ & $0(1)$ \\
\hline C35 & $32(2)$ & $38(2)$ & $25(2)$ & $5(2)$ & $8(2)$ & $-15(2)$ \\
\hline C36 & $24(2)$ & $34(2)$ & $16(2)$ & $-4(1)$ & $-2(1)$ & $-3(2)$ \\
\hline O11 & $83(5)$ & $27(4)$ & $24(4)$ & $-3(4)$ & $14(4)$ & $6(4)$ \\
\hline O12 & $39(3)$ & $23(2)$ & $11(2)$ & 2(2) & $3(2)$ & $3(3)$ \\
\hline C42 & $46(4)$ & $29(3)$ & $16(3)$ & $1(2)$ & $8(3)$ & $16(3)$ \\
\hline C52 & $54(5)$ & $55(5)$ & $70(5)$ & $-2(4)$ & $24(4)$ & $14(4)$ \\
\hline C53 & $90(6)$ & $55(5)$ & $18(3)$ & $-15(3)$ & $-9(3)$ & $31(5)$ \\
\hline
\end{tabular}




\begin{tabular}{|c|c|c|c|c|c|c|}
\hline O11A & $81(10)$ & $24(10)$ & $22(10)$ & $-11(9)$ & $9(9)$ & $10(9)$ \\
\hline O12A & $66(11)$ & $29(7)$ & $22(6)$ & $-1(5)$ & $12(8)$ & $8(9)$ \\
\hline $\mathrm{C} 42 \mathrm{~A}$ & $76(12)$ & $33(8)$ & $28(8)$ & $3(6)$ & $13(9)$ & $-3(10)$ \\
\hline C52A & $117(15)$ & $66(12)$ & $41(10)$ & $-5(9)$ & $40(11)$ & $10(12)$ \\
\hline C53A & $140(20)$ & $74(16)$ & $37(10)$ & $-10(11)$ & $-16(14)$ & $-1(16)$ \\
\hline O13 & $32(2)$ & $39(2)$ & $22(1)$ & 11(1) & $-1(1)$ & $4(1)$ \\
\hline O14 & $28(1)$ & $18(1)$ & $34(1)$ & $8(1)$ & $-4(1)$ & $-2(1)$ \\
\hline $\mathrm{O} 15$ & $25(1)$ & $17(1)$ & $22(1)$ & $2(1)$ & $-6(1)$ & $-1(1)$ \\
\hline O16 & $26(1)$ & $29(2)$ & $16(1)$ & 1(1) & $-3(1)$ & $7(1)$ \\
\hline O17 & $25(1)$ & $37(2)$ & $22(1)$ & 1(1) & $-4(1)$ & $3(1)$ \\
\hline O18 & $28(2)$ & $69(2)$ & $40(2)$ & $32(2)$ & $-13(1)$ & $-2(2)$ \\
\hline O19 & $27(2)$ & $51(3)$ & $18(2)$ & $2(2)$ & $-5(2)$ & $5(2)$ \\
\hline C67 & 19(2) & $29(3)$ & $20(2)$ & $12(2)$ & $-6(2)$ & $-5(2)$ \\
\hline O19A & $42(6)$ & $39(6)$ & $23(5)$ & $7(4)$ & $-6(4)$ & $10(5)$ \\
\hline C67A & $33(7)$ & $25(7)$ & $15(6)$ & $-5(5)$ & $-1(5)$ & $-8(6)$ \\
\hline $\mathrm{O} 20$ & $26(1)$ & $67(2)$ & $15(1)$ & $9(1)$ & $-3(1)$ & $1(1)$ \\
\hline C37 & $27(2)$ & $19(2)$ & 13(2) & $-1(1)$ & $-1(1)$ & 1(1) \\
\hline C38 & $28(2)$ & $25(2)$ & $16(2)$ & $4(1)$ & $3(1)$ & $3(2)$ \\
\hline C39 & $32(2)$ & $33(2)$ & $24(2)$ & $7(2)$ & $4(2)$ & $10(2)$ \\
\hline C40 & $53(3)$ & $27(2)$ & $30(2)$ & $2(2)$ & $4(2)$ & $16(2)$ \\
\hline C41 & $58(3)$ & $22(2)$ & 19(2) & $-2(2)$ & $5(2)$ & $-1(2)$ \\
\hline $\mathrm{C} 43$ & $49(2)$ & $22(2)$ & $15(2)$ & $-1(1)$ & $-4(2)$ & $0(2)$ \\
\hline C44 & $18(2)$ & $16(2)$ & $19(2)$ & $-2(1)$ & $-2(1)$ & $-1(1)$ \\
\hline $\mathrm{C} 45$ & $13(1)$ & $20(2)$ & $18(2)$ & 1(1) & $-1(1)$ & $-1(1)$ \\
\hline C46 & $15(2)$ & $25(2)$ & $19(2)$ & $-1(1)$ & $-2(1)$ & $2(1)$ \\
\hline C47 & $13(2)$ & $35(2)$ & $21(2)$ & $-7(2)$ & $-2(1)$ & $6(1)$ \\
\hline $\mathrm{C} 48$ & $19(2)$ & $40(2)$ & $13(2)$ & $-1(2)$ & $-3(1)$ & $6(2)$ \\
\hline C49 & $17(2)$ & $30(2)$ & $19(2)$ & $5(1)$ & $4(1)$ & $3(1)$ \\
\hline C50 & $15(2)$ & $22(2)$ & $20(2)$ & $4(1)$ & $-1(1)$ & 1(1) \\
\hline C51 & $15(2)$ & $21(2)$ & $23(2)$ & $3(1)$ & $0(1)$ & $-2(1)$ \\
\hline C54 & $24(2)$ & $39(2)$ & $26(2)$ & $-15(2)$ & $-6(2)$ & $4(2)$ \\
\hline C55 & $47(3)$ & $54(3)$ & $21(2)$ & $12(2)$ & $1(2)$ & $12(2)$ \\
\hline C56 & $20(2)$ & $23(2)$ & $16(2)$ & $-1(1)$ & $-1(1)$ & $-2(1)$ \\
\hline C57 & $21(2)$ & $17(2)$ & $20(2)$ & $3(1)$ & $-2(1)$ & $-3(1)$ \\
\hline C58 & $21(2)$ & $19(2)$ & $20(2)$ & $2(1)$ & $-6(1)$ & $-2(1)$ \\
\hline C59 & $19(2)$ & $28(2)$ & $22(2)$ & $9(1)$ & $-6(1)$ & $-4(2)$ \\
\hline C60 & $20(2)$ & $27(2)$ & $26(2)$ & $7(2)$ & $-4(1)$ & $-6(2)$ \\
\hline C61 & $22(2)$ & $21(2)$ & $35(2)$ & $5(2)$ & $-7(2)$ & $-4(2)$ \\
\hline C62 & $29(2)$ & $17(2)$ & $38(2)$ & $-4(2)$ & $-9(2)$ & $0(2)$ \\
\hline C63 & $35(2)$ & $23(2)$ & $56(3)$ & $-12(2)$ & $-14(2)$ & $9(2)$ \\
\hline C64 & $28(2)$ & $21(2)$ & $59(3)$ & $7(2)$ & $-19(2)$ & $1(2)$ \\
\hline C65 & $22(2)$ & $34(2)$ & $42(2)$ & $17(2)$ & $-11(2)$ & $-6(2)$ \\
\hline C66 & $18(2)$ & $50(3)$ & $35(2)$ & $19(2)$ & $-7(2)$ & $-5(2)$ \\
\hline C68 & $19(2)$ & $55(3)$ & $21(2)$ & $12(2)$ & $-2(1)$ & $-1(2)$ \\
\hline C69 & $25(2)$ & $36(2)$ & $18(2)$ & $7(2)$ & $-4(1)$ & $-7(2)$ \\
\hline C70 & $22(2)$ & $24(2)$ & $19(2)$ & $3(1)$ & $-2(1)$ & $-2(1)$ \\
\hline C71 & $38(3)$ & $73(4)$ & $58(3)$ & $40(3)$ & $-22(2)$ & $-2(3)$ \\
\hline C72 & $39(2)$ & $67(3)$ & $16(2)$ & $5(2)$ & $-2(2)$ & $10(2)$ \\
\hline
\end{tabular}


Table 5. Hydrogen coordinates ( $\left.\times 10^{4}\right)$ and isotropic displacement parameters $\left(\AA^{2} \times 10^{3}\right)$ for JG-IV-113.

\begin{tabular}{|c|c|c|c|c|}
\hline & $\mathrm{x}$ & $\mathrm{y}$ & z & $\mathrm{U}(\mathrm{eq})$ \\
\hline H6 & 11336 & 5713 & 5829 & 36 \\
\hline $\mathrm{H} 2$ & 4635 & 4355 & 5838 & 22 \\
\hline H3 & 2893 & 3433 & 5792 & 25 \\
\hline $\mathrm{H} 4 \mathrm{~A}$ & 3361 & 2729 & 5376 & 32 \\
\hline H4B & 5074 & 2523 & 5600 & 32 \\
\hline H5 & 7160 & 2725 & 5245 & 25 \\
\hline $\mathrm{H} 7$ & 8199 & 3764 & 5135 & 18 \\
\hline H8 & 9929 & 4101 & 5647 & 17 \\
\hline H10 & 8568 & 4960 & 6156 & 23 \\
\hline H12 & 8073 & 3749 & 6890 & 25 \\
\hline H16A & 2044 & 3734 & 4950 & 44 \\
\hline H16B & 2262 & 3461 & 4613 & 44 \\
\hline H16C & 2592 & 4237 & 4683 & 44 \\
\hline H17A & 5885 & 4164 & 4444 & 44 \\
\hline H17B & 5639 & 3381 & 4383 & 44 \\
\hline $\mathrm{H} 17 \mathrm{C}$ & 7448 & 3648 & 4575 & 44 \\
\hline H18A & 7453 & 4941 & 6931 & 50 \\
\hline H18B & 7807 & 5419 & 6646 & 50 \\
\hline $\mathrm{H} 18 \mathrm{C}$ & 9622 & 5122 & 6828 & 50 \\
\hline H19A & 7561 & 2008 & 6945 & 37 \\
\hline H19B & 6437 & 2708 & 6954 & 37 \\
\hline H19C & 8713 & 2677 & 7028 & 37 \\
\hline $\mathrm{H} 20 \mathrm{~A}$ & 5990 & 5053 & 5369 & 18 \\
\hline H20B & 7159 & 5126 & 5677 & 18 \\
\hline $\mathrm{H} 26$ & 16546 & 6797 & 5656 & 26 \\
\hline $\mathrm{H} 27$ & 19042 & 7313 & 5390 & 29 \\
\hline $\mathrm{H} 28$ & 19241 & 7220 & 4865 & 26 \\
\hline H34 & 7928 & 4948 & 4886 & 19 \\
\hline H35A & 18255 & 6708 & 4130 & 48 \\
\hline H35B & 19637 & 6700 & 4420 & 48 \\
\hline $\mathrm{H} 35 \mathrm{C}$ & 18282 & 7333 & 4355 & 48 \\
\hline H36A & 9401 & 5143 & 4140 & 37 \\
\hline H36B & 7893 & 5278 & 4408 & 37 \\
\hline $\mathrm{H} 36 \mathrm{C}$ & 9148 & 4605 & 4403 & 37 \\
\hline H52A & -2501 & 8208 & 3639 & 89 \\
\hline H52B & -2325 & 7425 & 3573 & 89 \\
\hline $\mathrm{H} 52 \mathrm{C}$ & -2771 & 7933 & 3303 & 89 \\
\hline H53A & 2658 & 7931 & 3673 & 81 \\
\hline H53B & 929 & 7548 & 3841 & 81 \\
\hline $\mathrm{H} 53 \mathrm{C}$ & 991 & 8346 & 3841 & 81 \\
\hline H52D & -882 & 8130 & 3813 & 112 \\
\hline H52E & -486 & 7359 & 3743 & 112 \\
\hline $\mathrm{H} 52 \mathrm{~F}$ & -1863 & 7787 & 3525 & 112 \\
\hline H53D & 3904 & 8260 & 3512 & 127 \\
\hline H53E & 3176 & 7755 & 3768 & 127 \\
\hline $\mathrm{H} 53 \mathrm{~F}$ & 2551 & 8524 & 3781 & 127 \\
\hline H16 & 5982 & 5786 & 2433 & 36 \\
\hline H38 & -1149 & 6998 & 2525 & 27 \\
\hline H39 & -2688 & 7969 & 2561 & 35 \\
\hline $\mathrm{H} 40 \mathrm{~A}$ & -1491 & 8830 & 2857 & 44 \\
\hline
\end{tabular}




$\begin{array}{lrlll}\text { H40B } & 51 & 8830 & 2588 & 44 \\ \text { H41 } & 2285 & 8740 & 2939 & 39 \\ \text { H43 } & 3317 & 7703 & 3061 & 34 \\ \text { H44 } & 4361 & 7214 & 2528 & 21 \\ \text { H46 } & 2339 & 6197 & 2143 & 24 \\ \text { H48 } & 1408 & 7113 & 1337 & 29 \\ \text { H54A } & 581 & 5919 & 1414 & 45 \\ \text { H54B } & 1304 & 5553 & 1715 & 45 \\ \text { H54C } & 2847 & 5775 & 1464 & 45 \\ \text { H55A } & 2404 & 8098 & 1107 & 61 \\ \text { H55B } & 1294 & 8797 & 1137 & 61 \\ \text { H55C } & 133 & 8113 & 1186 & 61 \\ \text { H56A } & 685 & 6406 & 2954 & 23 \\ \text { H56B } & 1625 & 6241 & 2635 & 23 \\ \text { H62 } & 11356 & 4843 & 2548 & 34 \\ \text { H63 } & 13980 & 4320 & 2779 & 45 \\ \text { H64 } & 14148 & 4238 & 3303 & 43 \\ \text { H70 } & 2724 & 6458 & 3400 & 26 \\ \text { H71A } & 13386 & 3952 & 3775 & 85 \\ \text { H71B } & 13143 & 4435 & 4060 & 85 \\ \text { H71C } & 14531 & 4647 & 3787 & 85 \\ \text { H72A } & 2684 & 5969 & 3852 & 61 \\ \text { H72B } & 3618 & 6698 & 3880 & 61 \\ \text { H72C } & 4076 & 6143 & 4130 & 61 \\ \end{array}$


Table 6. Torsion angles $\left[{ }^{\circ}\right]$ for JG-IV-113.

\begin{tabular}{|c|c|c|c|}
\hline $\mathrm{C} 7-\mathrm{C} 1-\mathrm{C} 2-\mathrm{C} 3$ & $29.7(5)$ & C12-C13-C14-C9 & $-2.0(5)$ \\
\hline $\mathrm{C} 8-\mathrm{C} 1-\mathrm{C} 2-\mathrm{C} 3$ & $-90.5(4)$ & O3-C13-C14-C15 & $-0.6(5)$ \\
\hline $\mathrm{C} 20-\mathrm{C} 1-\mathrm{C} 2-\mathrm{C} 3$ & $149.4(3)$ & C12-C13-C14-C15 & 179.1(3) \\
\hline $\mathrm{C} 1-\mathrm{C} 2-\mathrm{C} 3-\mathrm{C} 4$ & $-0.2(6)$ & $\mathrm{C} 8-\mathrm{O} 5-\mathrm{C} 15-\mathrm{O} 4$ & $173.3(3)$ \\
\hline C2-C3-C4-C5 & $-17.1(5)$ & C8-O5-C15-C14 & $-7.0(4)$ \\
\hline $\mathrm{C} 6-\mathrm{O} 1-\mathrm{C} 5-\mathrm{C} 4$ & $105.4(3)$ & C9-C14-C15-O4 & $-177.2(4)$ \\
\hline C6-O1-C5-C7 & $-19.0(4)$ & $\mathrm{C} 13-\mathrm{C} 14-\mathrm{C} 15-\mathrm{O} 4$ & $1.7(7)$ \\
\hline C3-C4-C5-O1 & $-114.3(3)$ & C9-C14-C15-O5 & $3.2(4)$ \\
\hline C3-C4-C5-C7 & $2.0(5)$ & C13-C14-C15-O5 & $-177.9(3)$ \\
\hline $\mathrm{C} 5-\mathrm{O} 1-\mathrm{C} 6-\mathrm{O} 2$ & $-0.6(4)$ & $\mathrm{C} 2-\mathrm{C} 1-\mathrm{C} 20-\mathrm{C} 21$ & $-179.1(3)$ \\
\hline C5-O1-C6-C16 & $-117.8(3)$ & C7-C1-C20-C21 & $-59.8(4)$ \\
\hline C5-O1-C6-C17 & $118.8(3)$ & C8-C1-C20-C21 & $60.7(4)$ \\
\hline C7-O2-C6-O1 & $22.1(4)$ & C1-C20-C21-C34 & $81.7(4)$ \\
\hline C7-O2-C6-C16 & $141.8(3)$ & $\mathrm{C} 1-\mathrm{C} 20-\mathrm{C} 21-\mathrm{C} 22$ & $-104.1(4)$ \\
\hline $\mathrm{C} 7-\mathrm{O} 2-\mathrm{C} 6-\mathrm{C} 17$ & $-95.3(3)$ & C34-C21-C22-O6 & $177.0(3)$ \\
\hline $\mathrm{C} 6-\mathrm{O} 2-\mathrm{C} 7-\mathrm{C} 5$ & $-33.2(3)$ & C20-C21-C22-O6 & $2.6(5)$ \\
\hline $\mathrm{C} 6-\mathrm{O} 2-\mathrm{C} 7-\mathrm{C} 1$ & $-157.9(3)$ & C34-C21-C22-C23 & $-2.8(5)$ \\
\hline $\mathrm{O} 1-\mathrm{C} 5-\mathrm{C} 7-\mathrm{O} 2$ & $31.4(3)$ & $\mathrm{C} 20-\mathrm{C} 21-\mathrm{C} 22-\mathrm{C} 23$ & $-177.3(3)$ \\
\hline $\mathrm{C} 4-\mathrm{C} 5-\mathrm{C} 7-\mathrm{O} 2$ & $-89.4(3)$ & O6-C22-C23-C32 & $179.0(3)$ \\
\hline $\mathrm{O} 1-\mathrm{C} 5-\mathrm{C} 7-\mathrm{C} 1$ & 149.2(3) & $\mathrm{C} 21-\mathrm{C} 22-\mathrm{C} 23-\mathrm{C} 32$ & $-1.2(5)$ \\
\hline C4-C5-C7-C1 & $28.3(4)$ & O6-C22-C23-C24 & $-3.3(5)$ \\
\hline $\mathrm{C} 2-\mathrm{C} 1-\mathrm{C} 7-\mathrm{O} 2$ & $72.2(3)$ & C21-C22-C23-C24 & $176.5(3)$ \\
\hline $\mathrm{C} 8-\mathrm{C} 1-\mathrm{C} 7-\mathrm{O} 2$ & $-167.2(3)$ & $\mathrm{C} 22-\mathrm{C} 23-\mathrm{C} 24-\mathrm{O} 7$ & $2.5(5)$ \\
\hline $\mathrm{C} 20-\mathrm{C} 1-\mathrm{C} 7-\mathrm{O} 2$ & $-46.4(4)$ & $\mathrm{C} 32-\mathrm{C} 23-\mathrm{C} 24-\mathrm{O} 7$ & $-179.8(3)$ \\
\hline $\mathrm{C} 2-\mathrm{C} 1-\mathrm{C} 7-\mathrm{C} 5$ & $-42.9(4)$ & $\mathrm{C} 22-\mathrm{C} 23-\mathrm{C} 24-\mathrm{C} 25$ & $-175.5(3)$ \\
\hline $\mathrm{C} 8-\mathrm{C} 1-\mathrm{C} 7-\mathrm{C} 5$ & $77.7(4)$ & C32-C23-C24-C25 & $2.2(5)$ \\
\hline C20-C1-C7-C5 & $-161.5(3)$ & O7-C24-C25-C26 & $-1.9(5)$ \\
\hline C15-O5-C8-C9 & $7.8(3)$ & $\mathrm{C} 23-\mathrm{C} 24-\mathrm{C} 25-\mathrm{C} 26$ & $176.2(3)$ \\
\hline C15-O5-C8-C1 & $-116.5(3)$ & O7-C24-C25-C30 & $176.4(3)$ \\
\hline C2-C1-C8-O5 & $81.1(3)$ & $\mathrm{C} 23-\mathrm{C} 24-\mathrm{C} 25-\mathrm{C} 30$ & $-5.5(5)$ \\
\hline $\mathrm{C} 7-\mathrm{C} 1-\mathrm{C} 8-\mathrm{O} 5$ & $-39.0(3)$ & С $30-\mathrm{C} 25-\mathrm{C} 26-\mathrm{C} 27$ & $3.0(5)$ \\
\hline C20-C1-C8-O5 & $-159.8(2)$ & $\mathrm{C} 24-\mathrm{C} 25-\mathrm{C} 26-\mathrm{C} 27$ & $-178.8(3)$ \\
\hline $\mathrm{C} 2-\mathrm{C} 1-\mathrm{C} 8-\mathrm{C} 9$ & $-35.2(4)$ & C25-C26-C27-C28 & $-0.3(6)$ \\
\hline $\mathrm{C} 7-\mathrm{C} 1-\mathrm{C} 8-\mathrm{C} 9$ & $-155.2(3)$ & С26-C27-С28-С29 & $-0.9(6)$ \\
\hline $\mathrm{C} 20-\mathrm{C} 1-\mathrm{C} 8-\mathrm{C} 9$ & $83.9(3)$ & C35-O8-C29-C28 & $2.9(5)$ \\
\hline O5-C8-C9-C14 & $-5.5(3)$ & C35-O8-C29-C30 & $-177.4(3)$ \\
\hline C1-C8-C9-C14 & $113.5(3)$ & $\mathrm{C} 27-\mathrm{C} 28-\mathrm{C} 29-\mathrm{O} 8$ & $179.0(3)$ \\
\hline O5-C8-C9-C10 & $175.9(3)$ & C27-C28-C29-C30 & $-0.6(5)$ \\
\hline C1-C8-C9-C10 & $-65.1(5)$ & $\mathrm{C} 26-\mathrm{C} 25-\mathrm{C} 30-\mathrm{C} 29$ & $-4.4(5)$ \\
\hline C14-C9-C10-C11 & $0.1(5)$ & $\mathrm{C} 24-\mathrm{C} 25-\mathrm{C} 30-\mathrm{C} 29$ & $177.4(3)$ \\
\hline C8-C9-C10-C11 & $178.5(3)$ & C26-C25-C30-C31 & $170.2(3)$ \\
\hline C9-C10-C11-C12 & $-0.8(5)$ & C24-C25-C30-C31 & $-8.0(5)$ \\
\hline C9-C10-C11-C18 & $178.2(3)$ & O8-C29-C30-C25 & $-176.4(3)$ \\
\hline $\mathrm{C} 10-\mathrm{C} 11-\mathrm{C} 12-\mathrm{C} 13$ & $0.1(6)$ & C28-C29-C30-C25 & $3.2(5)$ \\
\hline C18-C11-C12-C13 & $-178.9(4)$ & O8-C29-C30-C31 & $9.2(5)$ \\
\hline C19-O3-C13-C12 & $6.9(5)$ & C28-C29-C30-C31 & $-171.2(3)$ \\
\hline C19-O3-C13-C14 & $-173.4(3)$ & C25-C30-C31-O9 & $-151.5(4)$ \\
\hline C11-C12-C13-O3 & $-179.0(3)$ & C29-C30-C31-O9 & $22.9(5)$ \\
\hline C11-C12-C13-C14 & $1.3(5)$ & C25-C30-C31-C32 & $24.4(5)$ \\
\hline C10-C9-C14-C13 & $1.4(5)$ & C29-C30-C31-C32 & $-161.2(3)$ \\
\hline C8-C9-C14-C13 & $-177.4(3)$ & $\mathrm{C} 22-\mathrm{C} 23-\mathrm{C} 32-\mathrm{C} 33$ & $5.1(5)$ \\
\hline C10-C9-C14-C15 & $-179.6(3)$ & C24-C23-C32-C33 & $-172.6(3)$ \\
\hline C8-C9-C14-C15 & $1.6(4)$ & C22-C23-C32-C31 & $-167.6(3)$ \\
\hline O3-C13-C14-C9 & $178.3(3)$ & C24-C23-C32-C31 & $14.7(5)$ \\
\hline
\end{tabular}




$\begin{array}{lc} & \\ \text { O9-C31-C32-C33 } & -24.5(5) \\ \text { C30-C31-C32-C33 } & 159.6(3) \\ \text { O9-C31-C32-C23 } & 148.0(4) \\ \text { C30-C31-C32-C23 } & -27.9(5) \\ \text { C36-O10-C33-C32 } & 174.3(3) \\ \text { C36-O10-C33-C34 } & -7.5(5) \\ \text { C23-C32-C33-O10 } & 173.4(3) \\ \text { C31-C32-C33-O10 } & -14.1(5) \\ \text { C23-C32-C33-C34 } & -4.9(5) \\ \text { C31-C32-C33-C34 } & 167.6(3) \\ \text { C22-C21-C34-C33 } & 3.0(5) \\ \text { C20-C21-C34-C33 } & 177.3(3) \\ \text { O10-C33-C34-C21 } & -177.3(3) \\ \text { C32-C33-C34-C21 } & 0.9(5) \\ \text { C41-O11-C42-O12 } & 3.8(13) \\ \text { C41-O11-C42-C53 } & 123.1(9) \\ \text { C41-O11-C42-C52 } & -112.5(10) \\ \text { C43-O12-C42-O11 } & 15.5(10) \\ \text { C43-O12-C42-C53 } & -102.5(7) \\ \text { C43-O12-C42-C52 } & 133.6(6) \\ \text { C41-O11A-C42A-O12A } & -15(3) \\ \text { C41-O11A-C42A-C53A } & 104(2) \\ \text { C41-O11A-C42A-C52A } & -131(2) \\ \text { C43-O12A-C42A-O11A } & 23(2) \\ \text { C43-O12A-C42A-C53A } & -94.9(17) \\ \text { C43-O12A-C42A-C52A } & 140.8(16) \\ \text { C43-C37-C38-C39 } & 32.2(5) \\ \text { C56-C37-C38-C39 } & 151.7(3) \\ \text { C44-C37-C38-C39 } & -88.6(4) \\ \text { C37-C38-C39-C40 } & 1.8(6) \\ \text { C38-C39-C40-C41 } & -25.5(6) \\ \text { C42A-O11A-C41-C40 } & 127.5(17) \\ \text { C42A-O11A-C41-C43 } & 3(2) \\ \text { C42-O11-C41-C40 } & 103.6(9) \\ \text { C42-O11-C41-C43 } & -20.2(12) \\ \text { C39-C40-C41-O11A } & -104.8(12) \\ \text { C39-C40-C41-O11 } & -103.9(6) \\ \text { C39-C40-C41-C43 } & 11.8(6) \\ \text { C42A-O12A-C43-C37 } & -156.4(11) \\ \text { C42A-O12A-C43-C41 } & -21.2(16) \\ \text { C42-O12-C43-C37 } & -150.4(5) \\ \text { C42-O12-C43-C41 } & -27.0(6) \\ \text { C38-C37-C43-O12A } & 87.8(10) \\ \text { C56-C37-C43-O12A } & -30.4(10) \\ \text { C44-C37-C43-O12A } & -151.0(10) \\ \text { C38-C37-C43-O12 } & 69.2(5) \\ \text { C56-C37-C43-O12 } & -49.0(5) \\ \text { C44-C37-C43-O12 } & -169.6(4) \\ \text { C38-C37-C43-C41 } & -43.2(5) \\ \text { C56-C37-C43-C41 } & -161.4(4) \\ \text { C44-C37-C43-C41 } & 78.0(5) \\ \text { O11A-C41-C43-O12A } & 11.6(17) \\ \text { C40-C41-C43-O12A } & -111.2(9) \\ \text { O11-C41-C43-O12 } & 27.5(8) \\ \text { C40-C41-C43-O12 } & -91.7(4) \\ \text { O11A-C41-C43-C37 } & 145.5(15) \\ & \end{array}$

$\begin{array}{lc} & \\ \text { O11-C41-C43-C37 } & 141.9(7) \\ \text { C40-C41-C43-C37 } & 22.6(6) \\ \text { C51-O15-C44-C45 } & 4.5(4) \\ \text { C51-O15-C44-C37 } & -120.1(3) \\ \text { C38-C37-C44-O15 } & 78.6(4) \\ \text { C43-C37-C44-O15 } & -41.4(4) \\ \text { C56-C37-C44-O15 } & -162.4(3) \\ \text { C38-C37-C44-C45 } & -38.2(4) \\ \text { C43-C37-C44-C45 } & -158.2(3) \\ \text { C56-C37-C44-C45 } & 80.8(4) \\ \text { O15-C44-C45-C46 } & 175.0(3) \\ \text { C37-C44-C45-C46 } & -65.6(5) \\ \text { O15-C44-C45-C50 } & -2.4(4) \\ \text { C37-C44-C45-C50 } & 117.1(3) \\ \text { C50-C45-C46-C47 } & 0.4(5) \\ \text { C44-C45-C46-C47 } & -176.6(3) \\ \text { C45-C46-C47-C48 } & -0.8(5) \\ \text { C45-C46-C47-C54 } & 177.2(3) \\ \text { C46-C47-C48-C49 } & 0.4(5) \\ \text { C54-C47-C48-C49 } & -177.6(3) \\ \text { C55-O13-C49-C48 } & 0.5(5) \\ \text { C55-O13-C49-C50 } & -179.6(3) \\ \text { C47-C48-C49-O13 } & -179.7(3) \\ \text { C47-C48-C49-C50 } & 0.4(5) \\ \text { C46-C45-C50-C49 } & 0.4(5) \\ \text { C44-C45-C50-C49 } & 178.1(3) \\ \text { C46-C45-C50-C51 } & -178.1(3) \\ \text { C44-C45-C50-C51 } & -0.4(4) \\ \text { O13-C49-C50-C45 } & 179.3(3) \\ \text { C48-C49-C50-C45 } & -0.8(5) \\ \text { O13-C49-C50-C51 } & -2.6(5) \\ \text { C48-C49-C50-C51 } & 177.3(3) \\ \text { C44-O15-C51-O14 } & 176.5(3) \\ \text { C44-O15-C51-C50 } & -4.8(4) \\ \text { C45-C50-C51-O14 } & -178.4(4) \\ \text { C49-C50-C51-O14 } & 3.3(7) \\ \text { C45-C50-C51-O15 } & 3.2(4) \\ \text { C49-C50-C51-O15 } & -175.1(3) \\ \text { C38-C37-C56-C57 } & -173.1(3) \\ \text { C43-C37-C56-C57 } & -54.6(4) \\ \text { C44-C37-C56-C57 } & 66.4(4) \\ \text { C37-C56-C57-C70 } & 92.4(4) \\ \text { C37-C56-C57-C58 } & -94.8(4) \\ \text { C70-C57-C58-O16 } & 178.8(3) \\ \text { C56-C57-C58-O16 } & 5.8(5) \\ \text { C70-C57-C58-C59 } & 0.2(5) \\ \text { C56-C57-C58-C59 } & -172.9(3) \\ \text { O16-C58-C59-C68 } & -179.9(4) \\ \text { C57-C58-C59-C68 } & -1.3(6) \\ \text { O16-C58-C59-C60 } & -1.4(5) \\ \text { C57-C58-C59-C60 } & 177.2(3) \\ \text { C58-C59-C60-O17 } & 3.2(6) \\ \text { C68-C59-C60-O17 } & -178.3(4) \\ \text { C58-C59-C60-C61 } & -177.1(3) \\ \text { C68-C59-C60-C61 } & 1.4(6) \\ \text { O17-C60-C61-C62 } & 2.1(5) \\ & \\ & \end{array}$




$\begin{array}{lc}\text { C59-C60-C61-C62 } & -177.6(4) \\ \text { O17-C60-C61-C66 } & 178.5(4) \\ \text { C59-C60-C61-C66 } & -1.2(6) \\ \text { C66-C61-C62-C63 } & 4.2(6) \\ \text { C60-C61-C62-C63 } & -179.5(4) \\ \text { C61-C62-C63-C64 } & 0.0(6) \\ \text { C62-C63-C64-C65 } & -1.9(7) \\ \text { C71-O18-C65-C64 } & -0.1(7) \\ \text { C71-O18-C65-C66 } & -178.2(4) \\ \text { C63-C64-C65-O18 } & -178.3(4) \\ \text { C63-C64-C65-C66 } & -0.3(7) \\ \text { C62-C61-C66-C65 } & -6.2(6) \\ \text { C60-C61-C66-C65 } & 177.6(4) \\ \text { C62-C61-C66-C67A } & -158.9(6) \\ \text { C60-C61-C66-C67A } & 24.8(7) \\ \text { C62-C61-C66-C67 } & 161.8(4) \\ \text { C60-C61-C66-C67 } & -14.5(6) \\ \text { O18-C65-C66-C61 } & -177.7(4) \\ \text { C64-C65-C66-C61 } & 4.2(6) \\ \text { O18-C65-C66-C67A } & -27.5(9) \\ \text { C64-C65-C66-C67A } & 154.4(7) \\ \text { O18-C65-C66-C67 } & 14.8(6) \\ \text { C64-C65-C66-C67 } & -163.4(4) \\ \text { O19A-C67A-C66-C61 } & 153.1(11) \\ \text { C68-C67A-C66-C61 } & -48.1(11) \\ \text { O19A-C67A-C66-C65 } & 1.7(16) \\ \text { C68-C67A-C66-C65 } & 160.5(6) \\ \text { O19-C67-C66-C61 } & -151.5(5) \\ \text { C68-C67-C66-C61 } & 28.5(6)\end{array}$

$\begin{array}{lc}\text { O19-C67-C66-C65 } & 15.9(8) \\ \text { C68-C67-C66-C65 } & -164.0(4) \\ \text { C58-C59-C68-C69 } & 1.0(6) \\ \text { C60-C59-C68-C69 } & -177.5(4) \\ \text { C58-C59-C68-C67 } & -166.6(4) \\ \text { C60-C59-C68-C67 } & 14.8(6) \\ \text { C58-C59-C68-C67A } & 154.6(6) \\ \text { C60-C59-C68-C67A } & -24.0(7) \\ \text { O19-C67-C68-C69 } & -16.4(8) \\ \text { C66-C67-C68-C69 } & 163.6(4) \\ \text { O19-C67-C68-C59 } & 151.2(5) \\ \text { C66-C67-C68-C59 } & -28.8(6) \\ \text { O19A-C67A-C68-C69 } & -1.4(16) \\ \text { C66-C67A-C68-C69 } & -159.6(6) \\ \text { O19A-C67A-C68-C59 } & -153.8(11) \\ \text { C66-C67A-C68-C59 } & 48.0(10) \\ \text { C72-O20-C69-C68 } & -172.8(4) \\ \text { C72-O20-C69-C70 } & 4.8(6) \\ \text { C59-C68-C69-O20 } & 178.1(4) \\ \text { C67-C68-C69-O20 } & -14.0(6) \\ \text { C67A-C68-C69-O20 } & 27.3(8) \\ \text { C59-C68-C69-C70 } & 0.4(6) \\ \text { C67-C68-C69-C70 } & 168.2(4) \\ \text { C67A-C68-C69-C70 } & -150.4(7) \\ \text { C58-C57-C70-C69 } & 1.3(6) \\ \text { C56-C57-C70-C69 } & 174.4(3) \\ \text { O20-C69-C70-C57 } & -179.2(4) \\ \text { C68-C69-C70-C57 } & -1.6(6) \\ & \end{array}$


Spectral Data of New Compounds

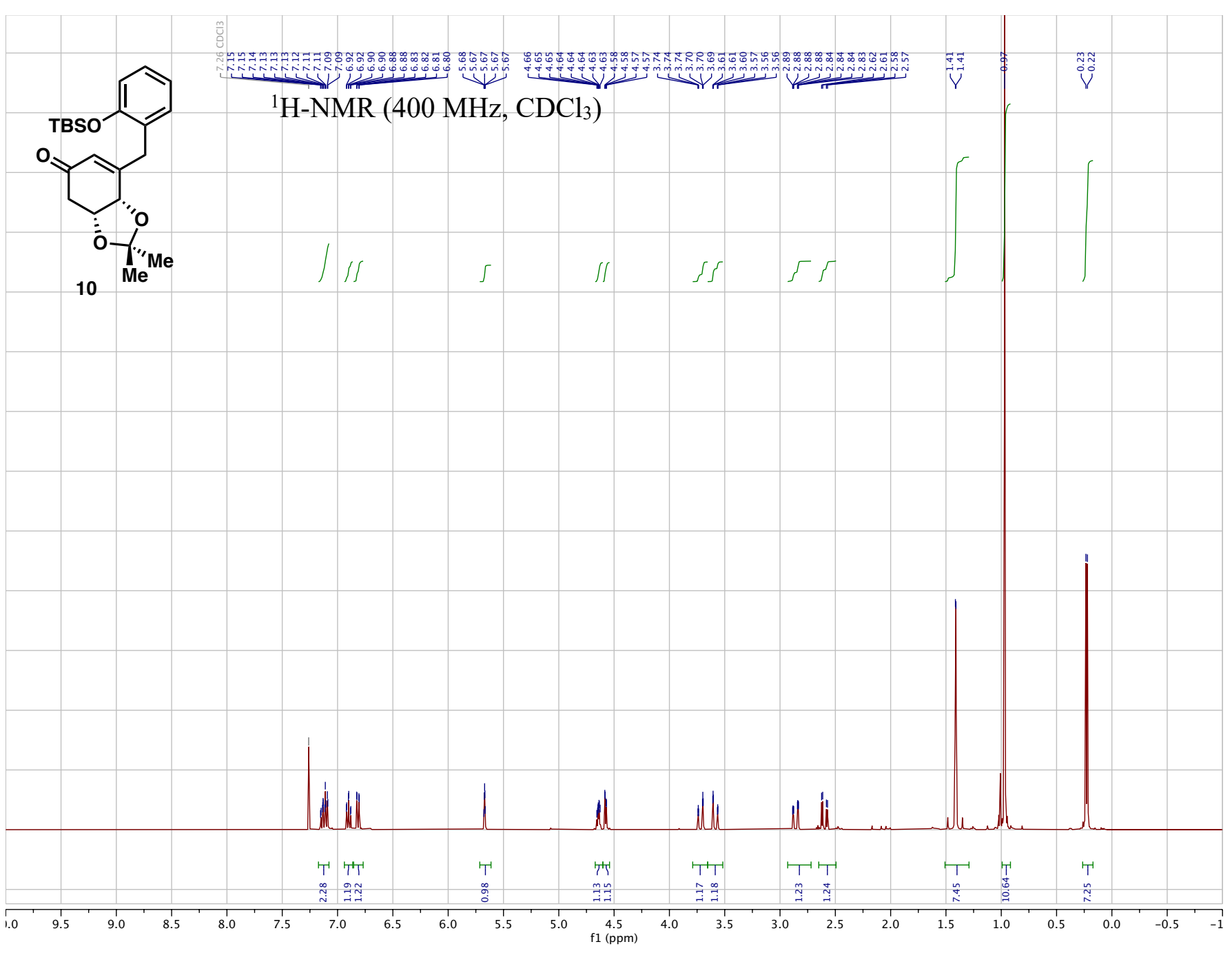

S58 


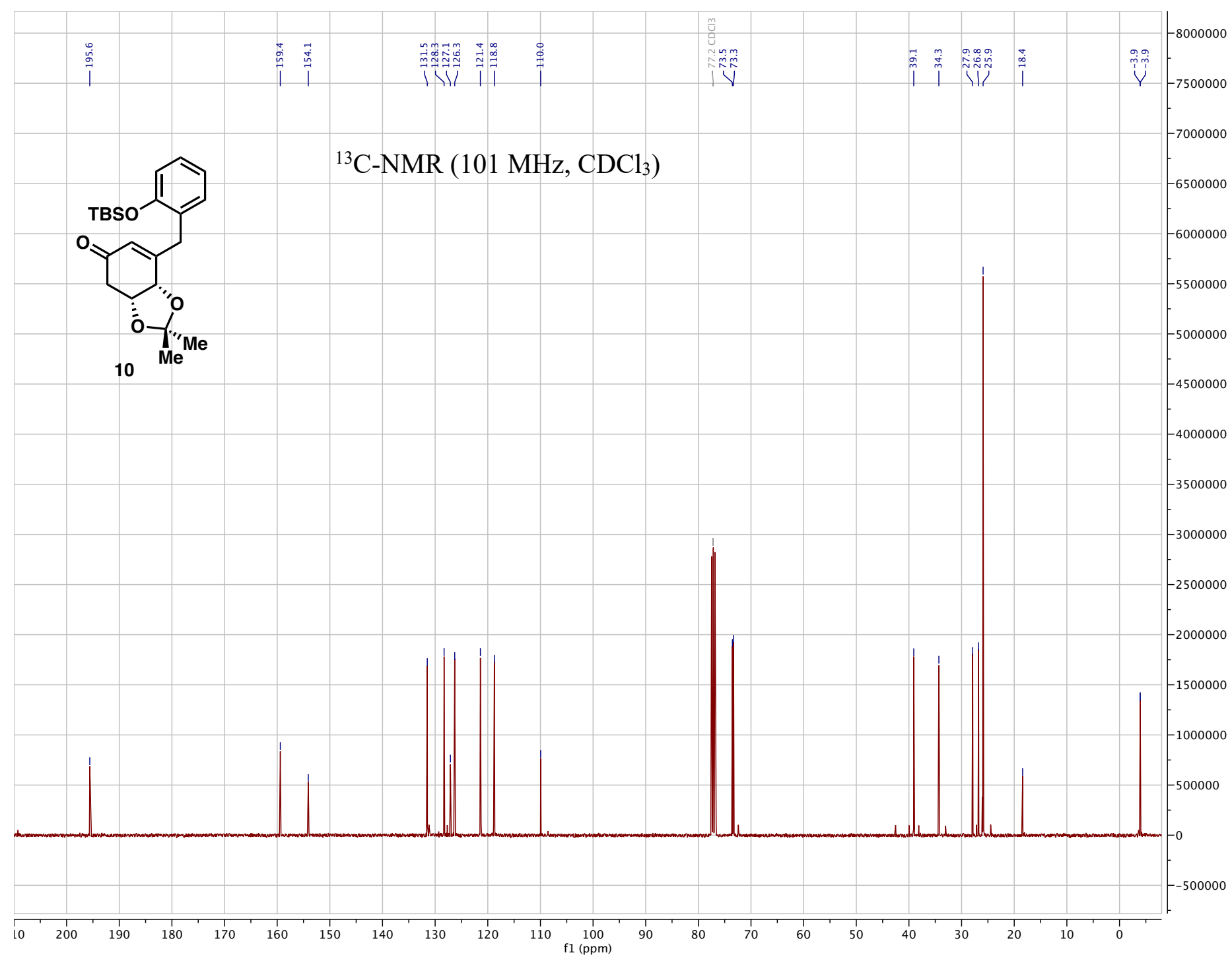




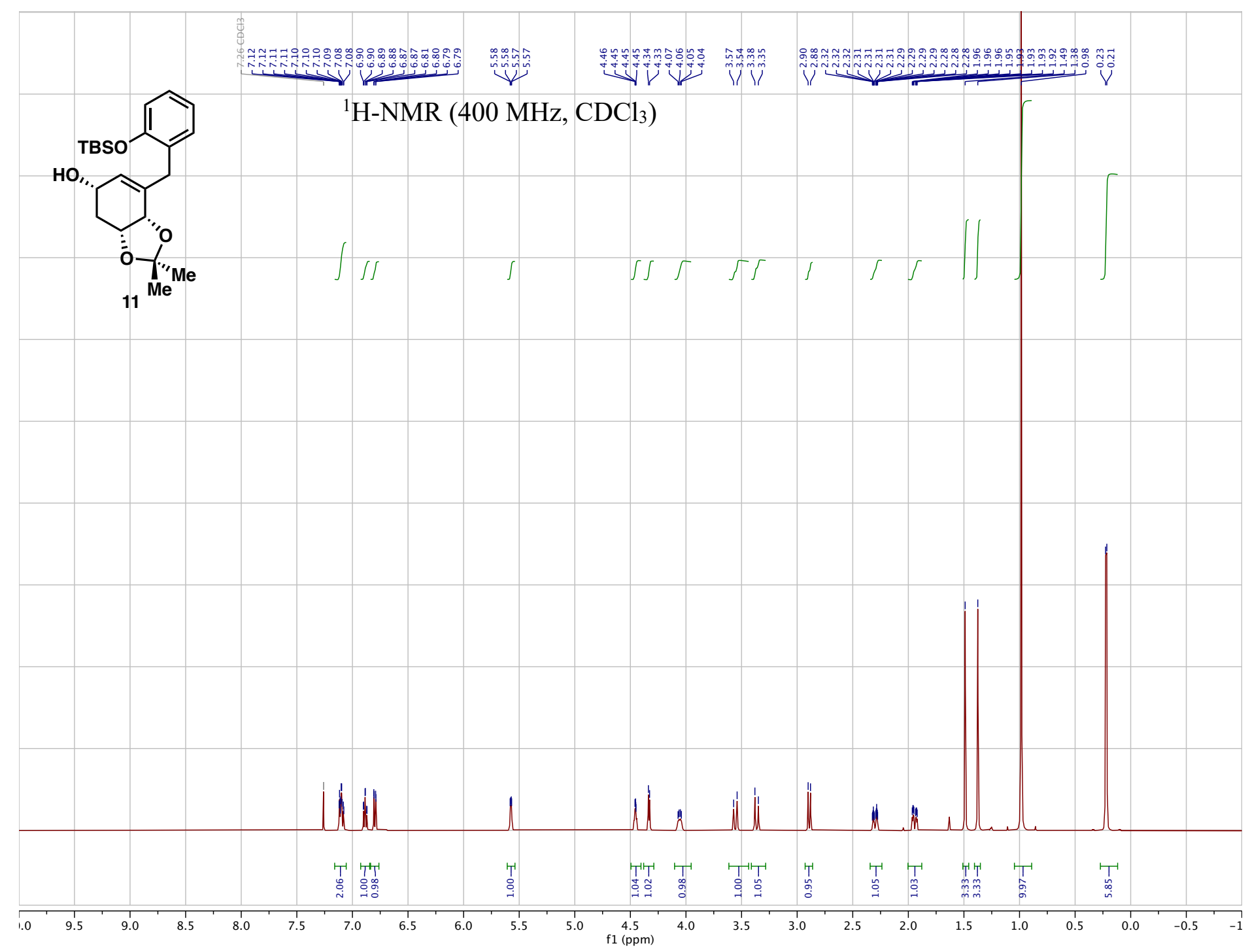




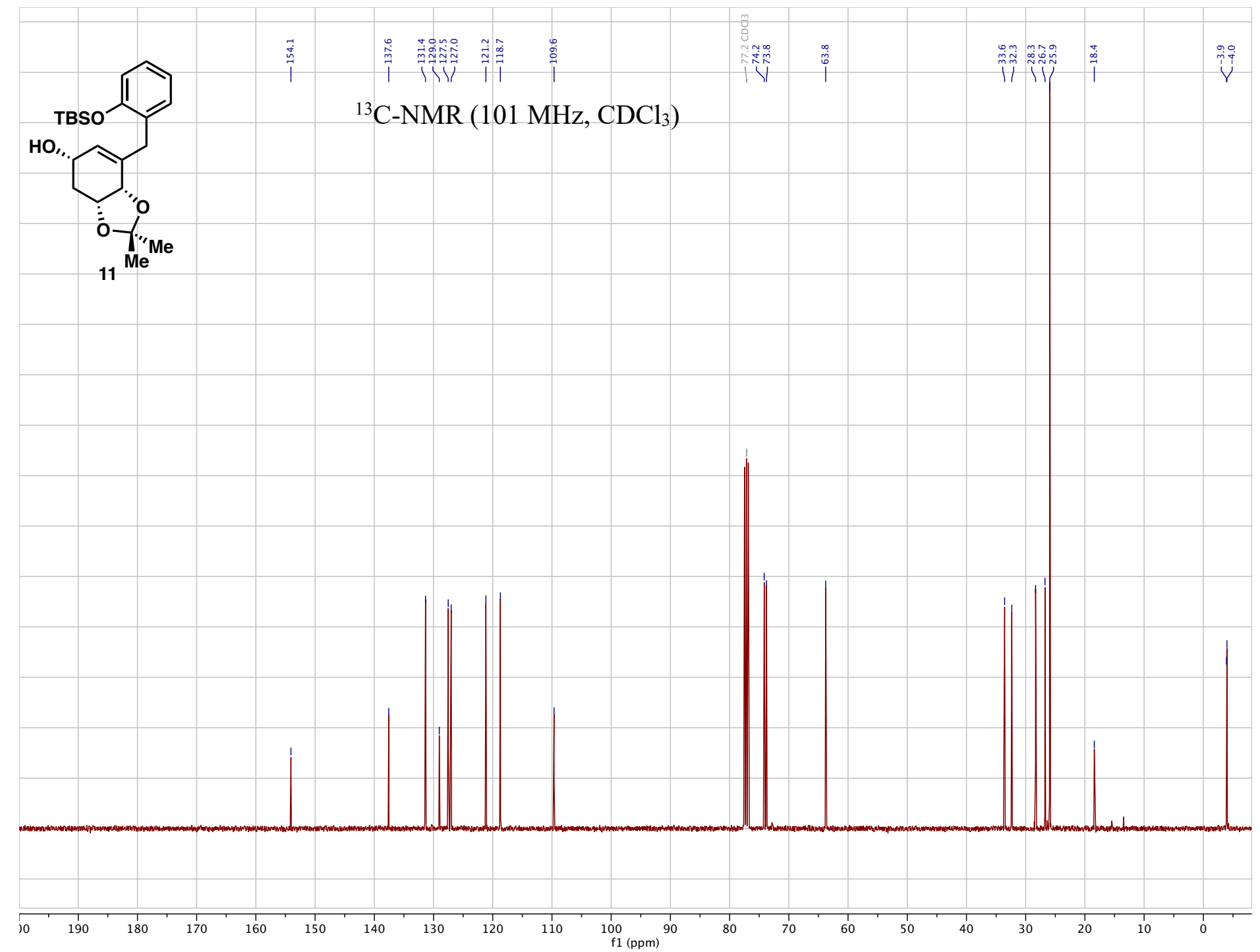




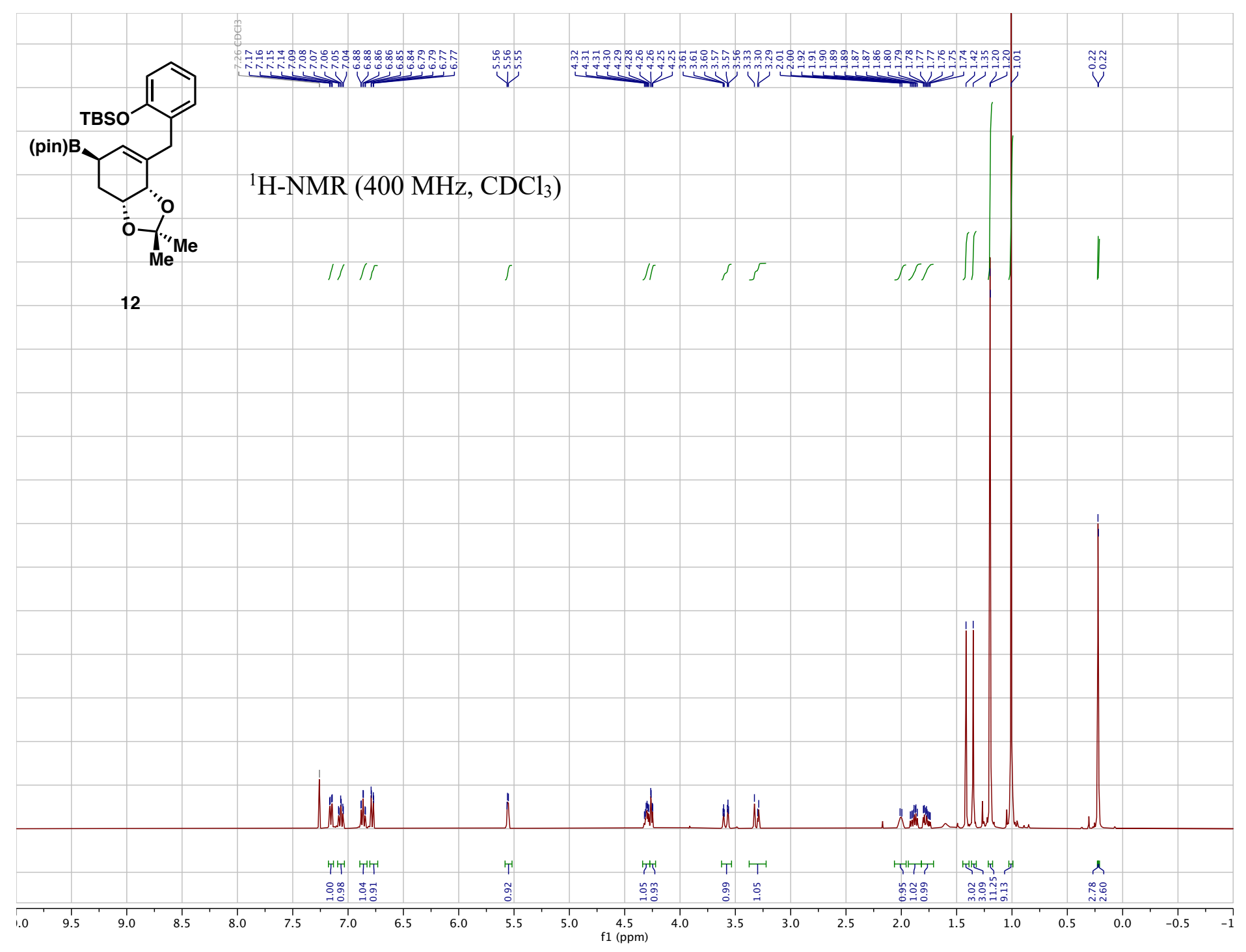




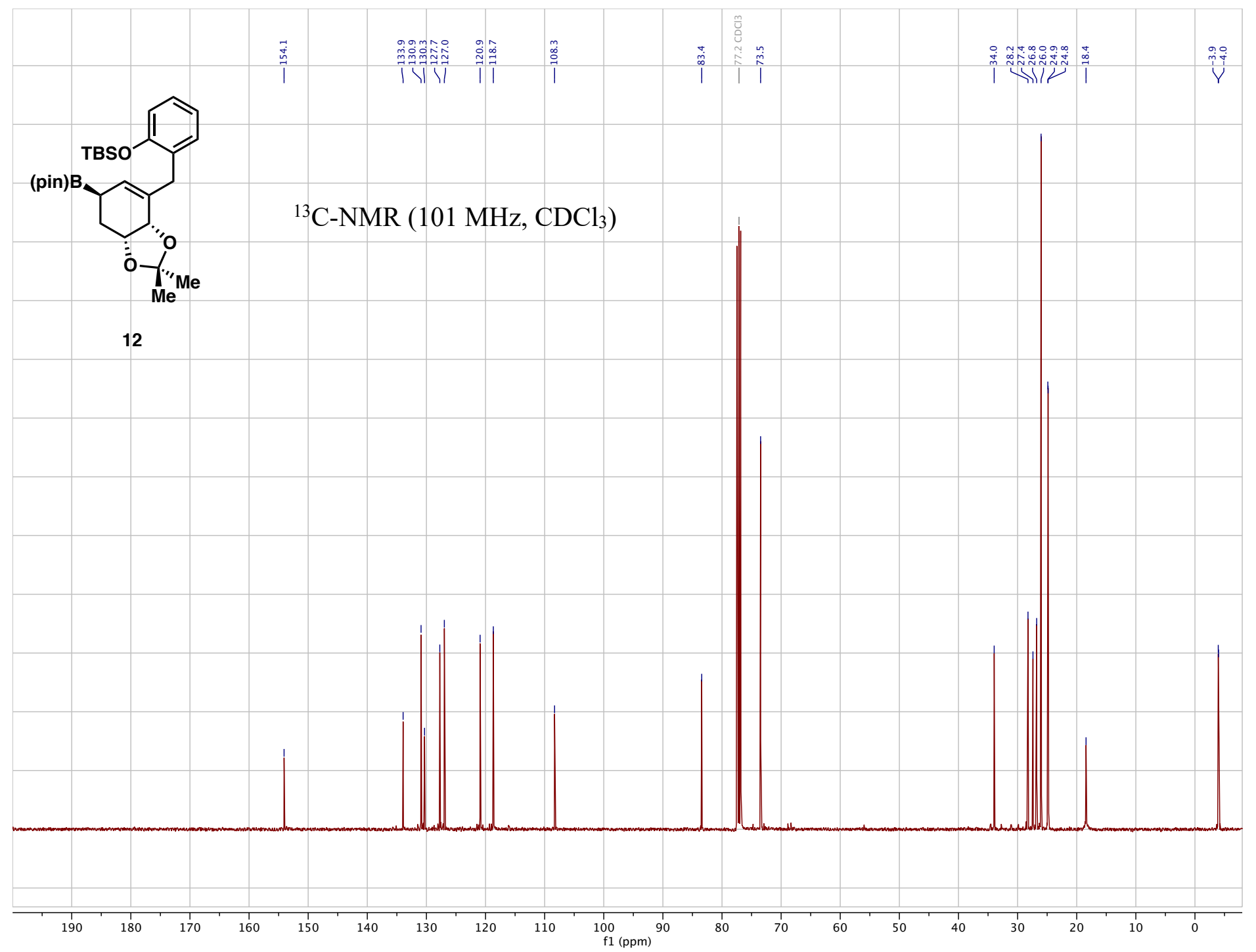




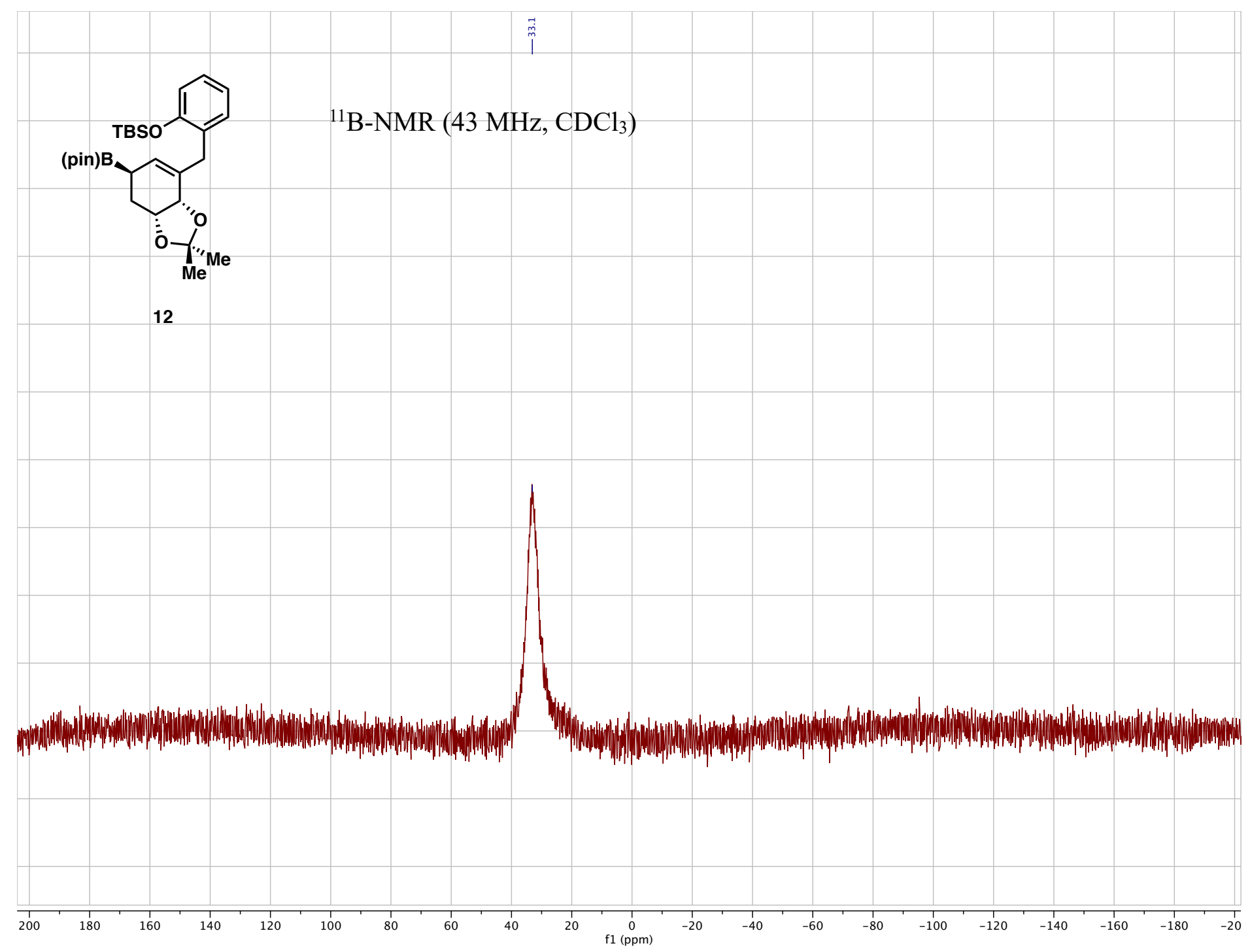




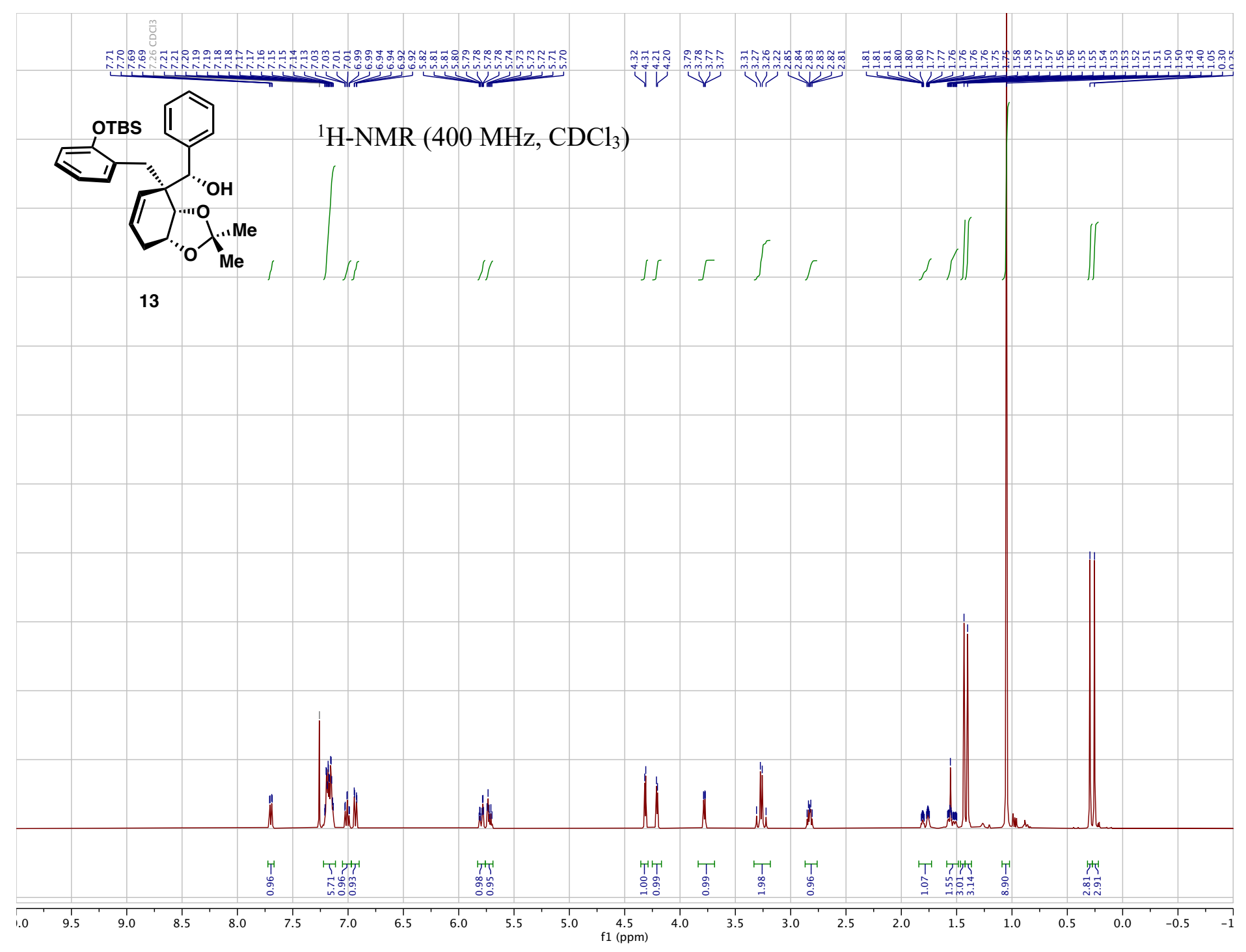



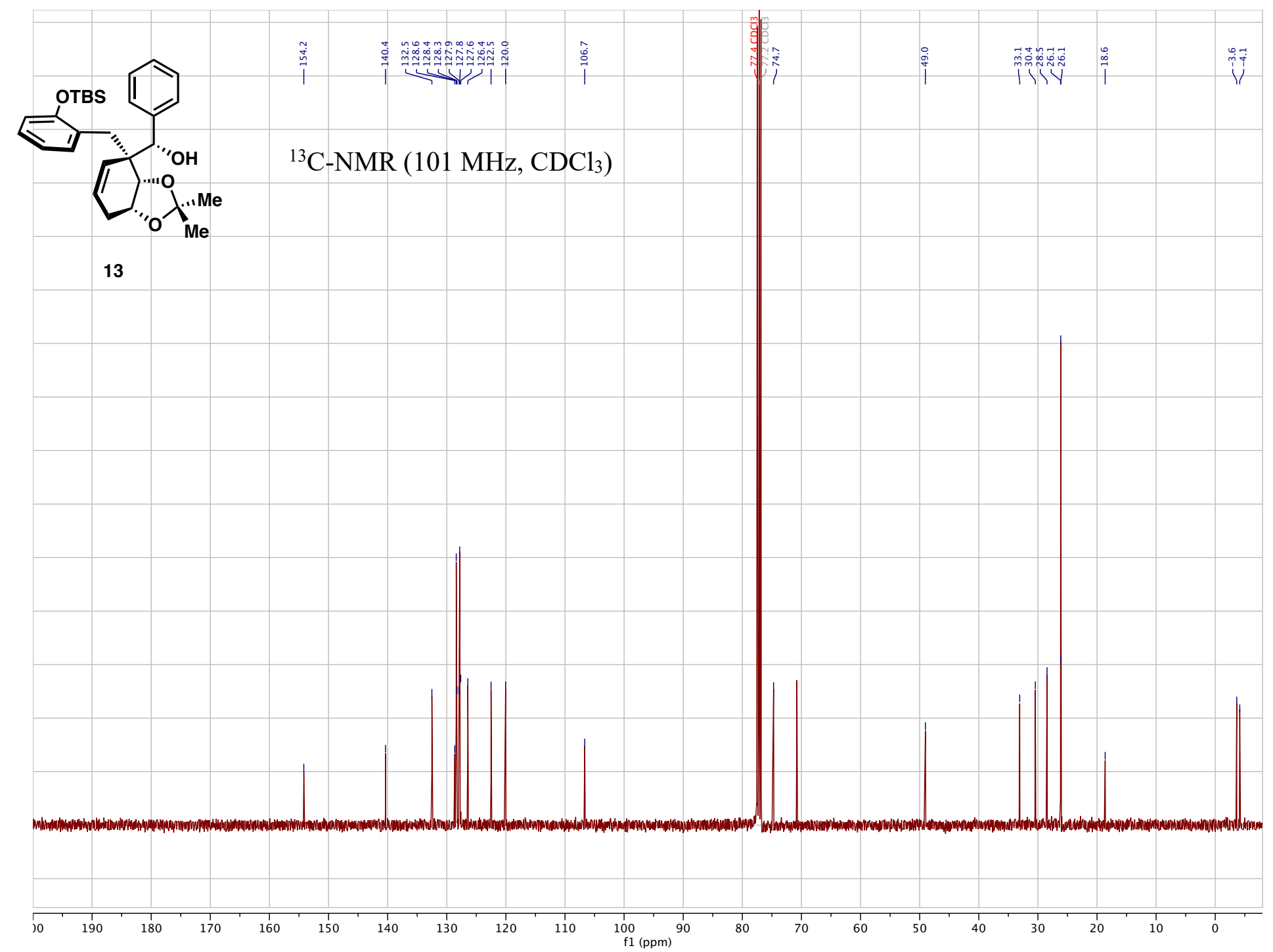
Rubellin model allylation ${ }^{1} \mathrm{H}$ NMR $\left(\mathrm{CDCl}_{3}\right)$ crude analysis with allylboron reagent 12 and PhCHO: starting material 12 (top); product 13 (middle); crude extract (bottom).

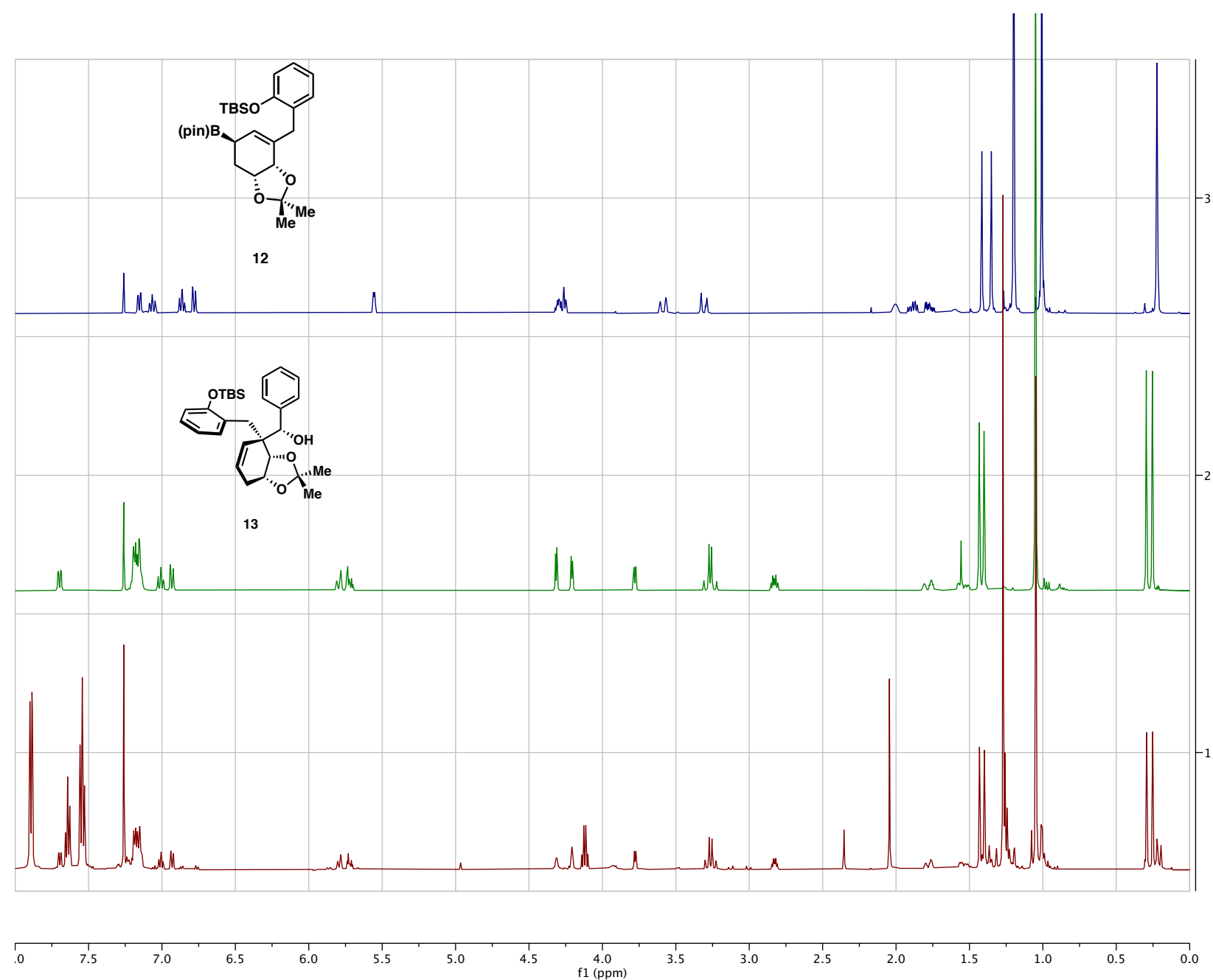




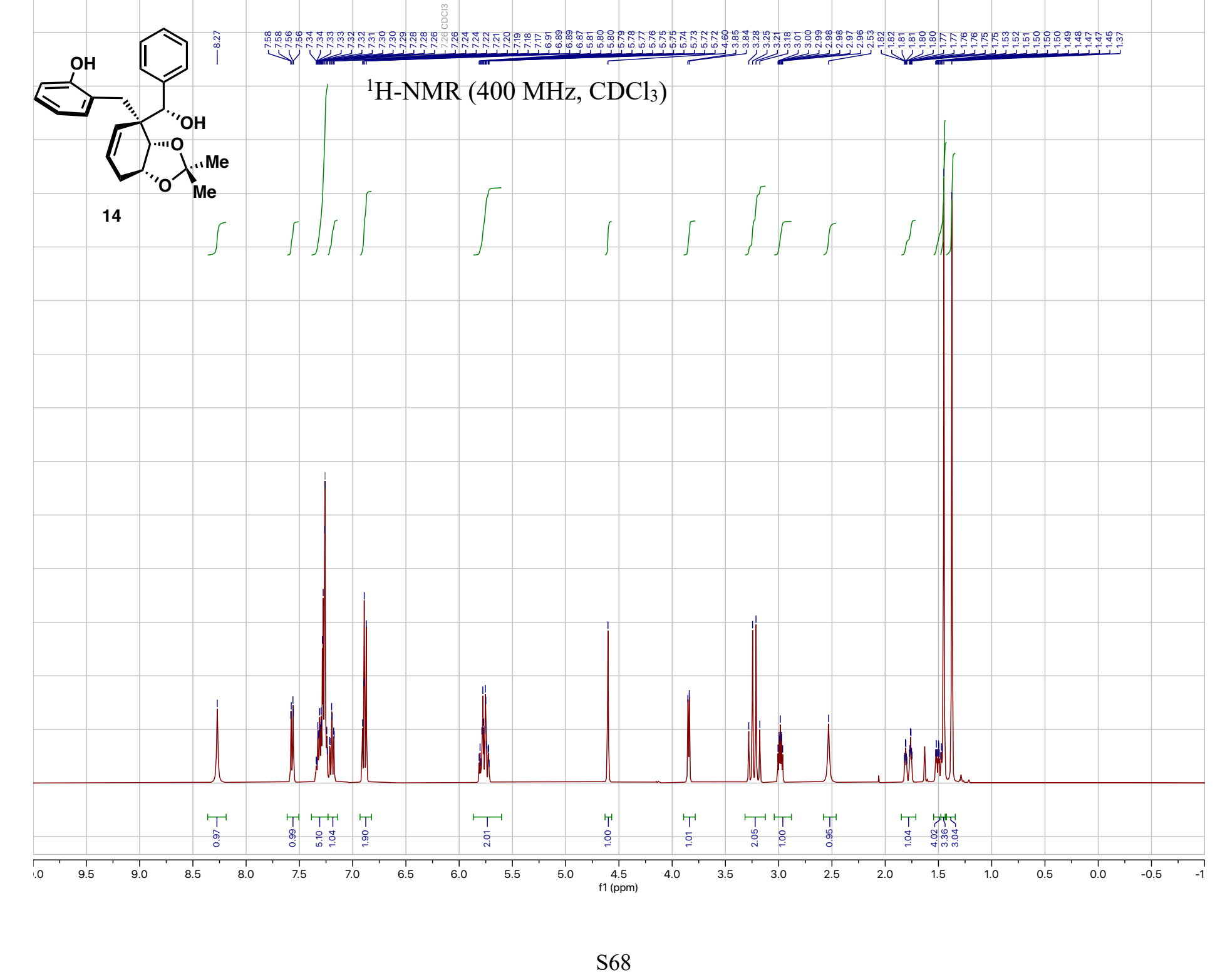




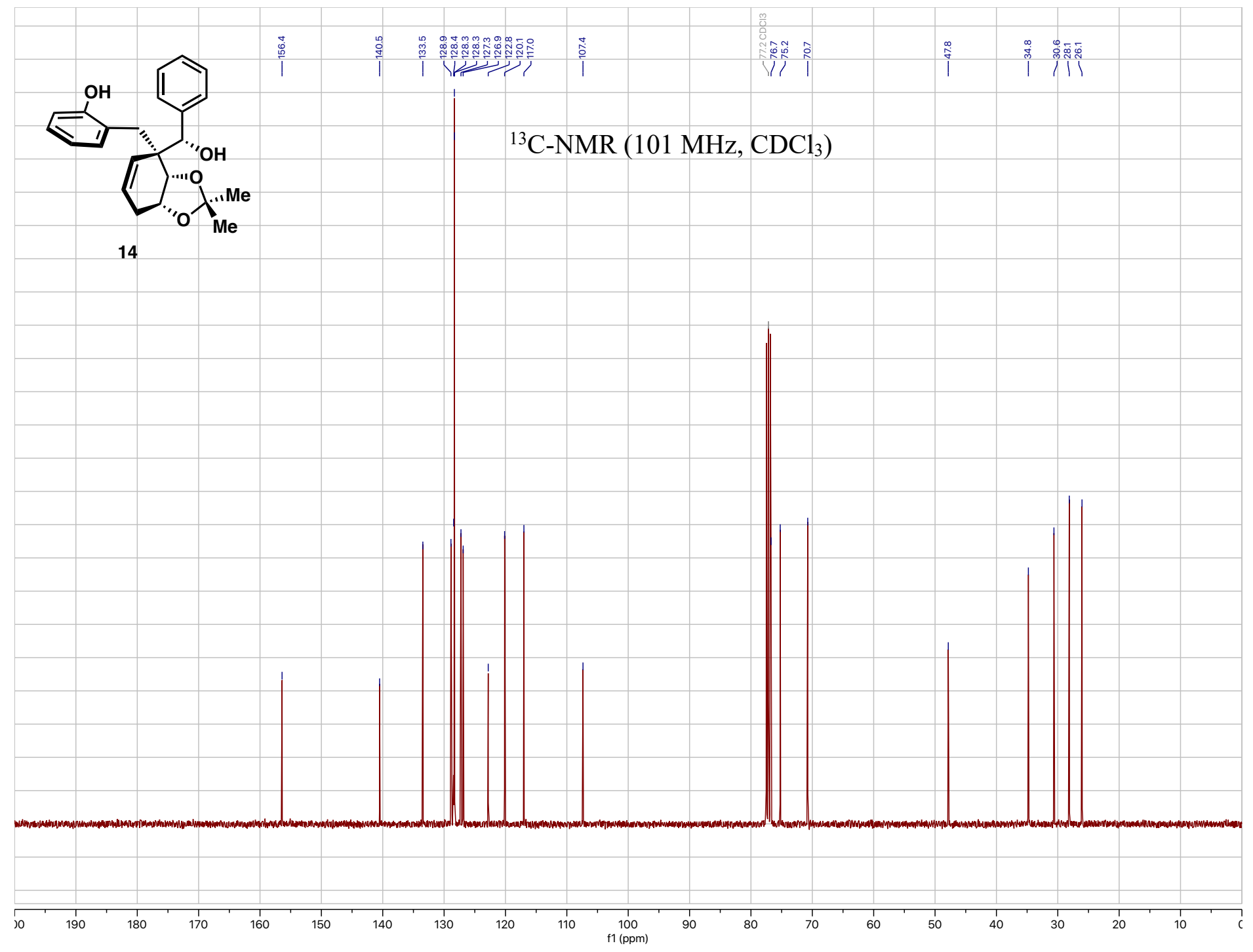




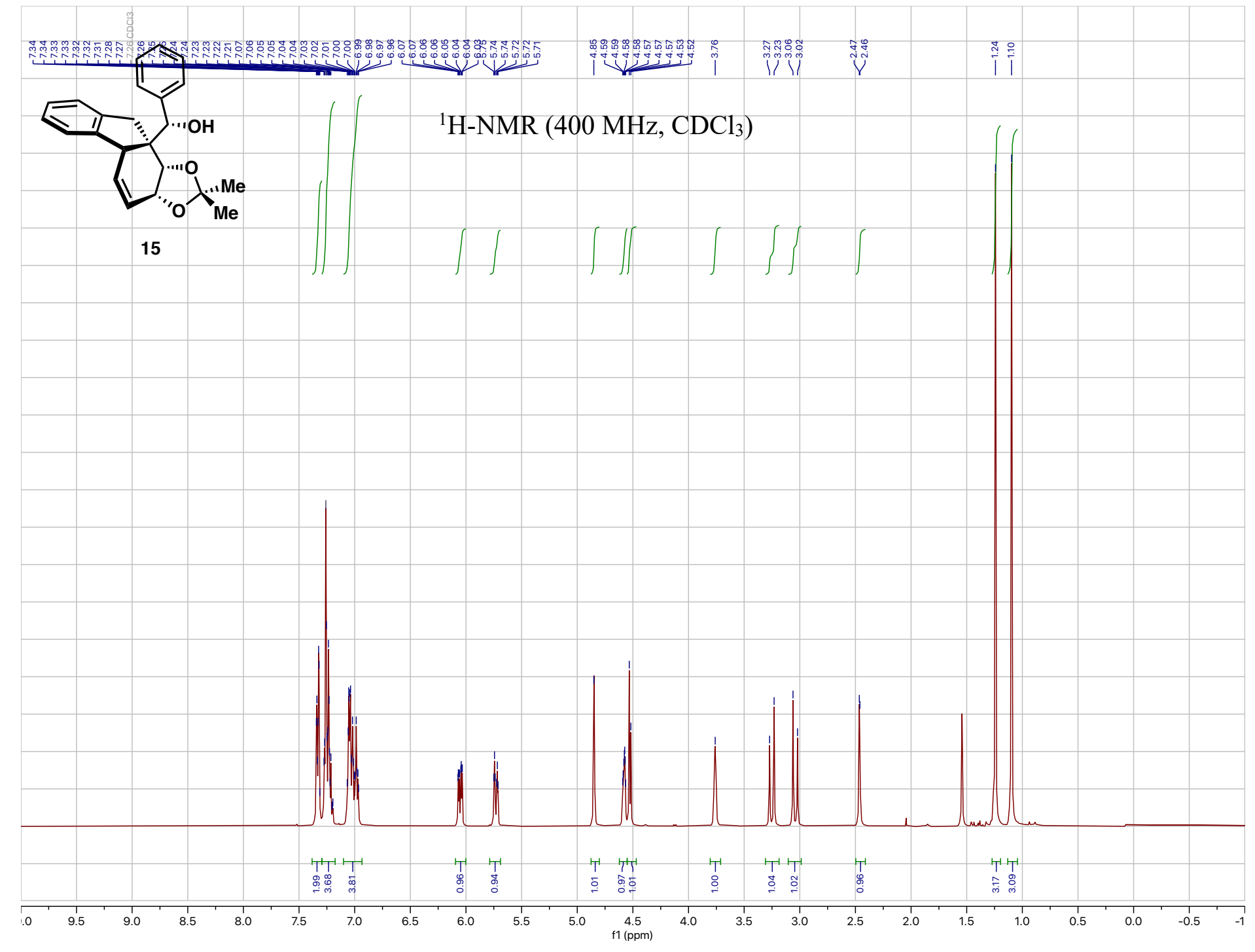




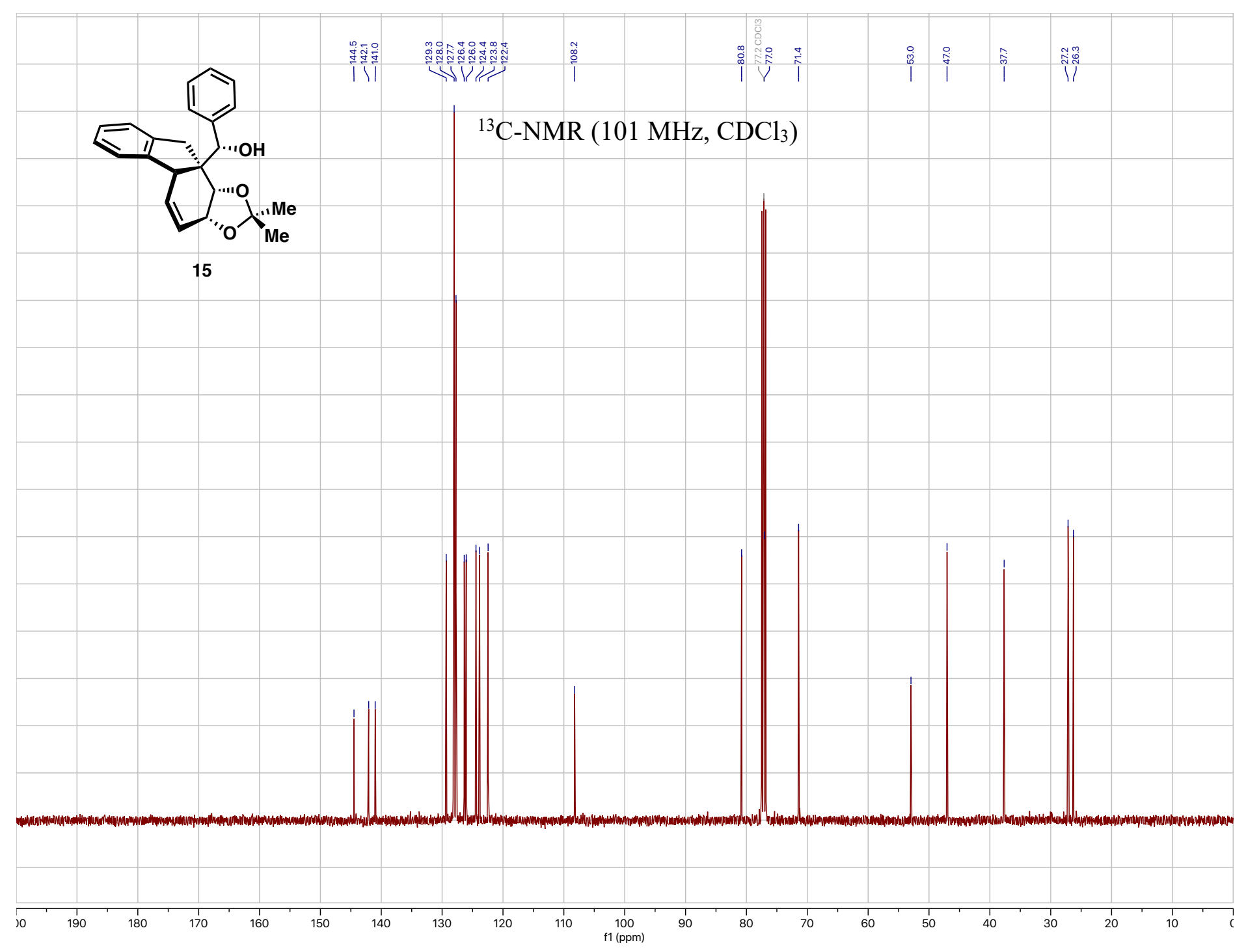


Rubellin core Heck reaction ${ }^{1} \mathbf{H}$ NMR $\left(\mathbf{C D C l}_{3}\right)$ crude analysis: Heck reaction product 15 (top), crude extract (bottom). Note: crude extract in this experiment also contains 1,4-dimethoxybenzene as an internal standard ${ }^{1} \mathrm{H} \mathrm{NMR}\left(\mathrm{CDCl}_{3}\right): \delta 3.75(\mathrm{~s}, 6 \mathrm{H}) ; 6.83(\mathrm{~s}, 4 \mathrm{H})$. Alcohol O-H proton is not visible in crude extract.

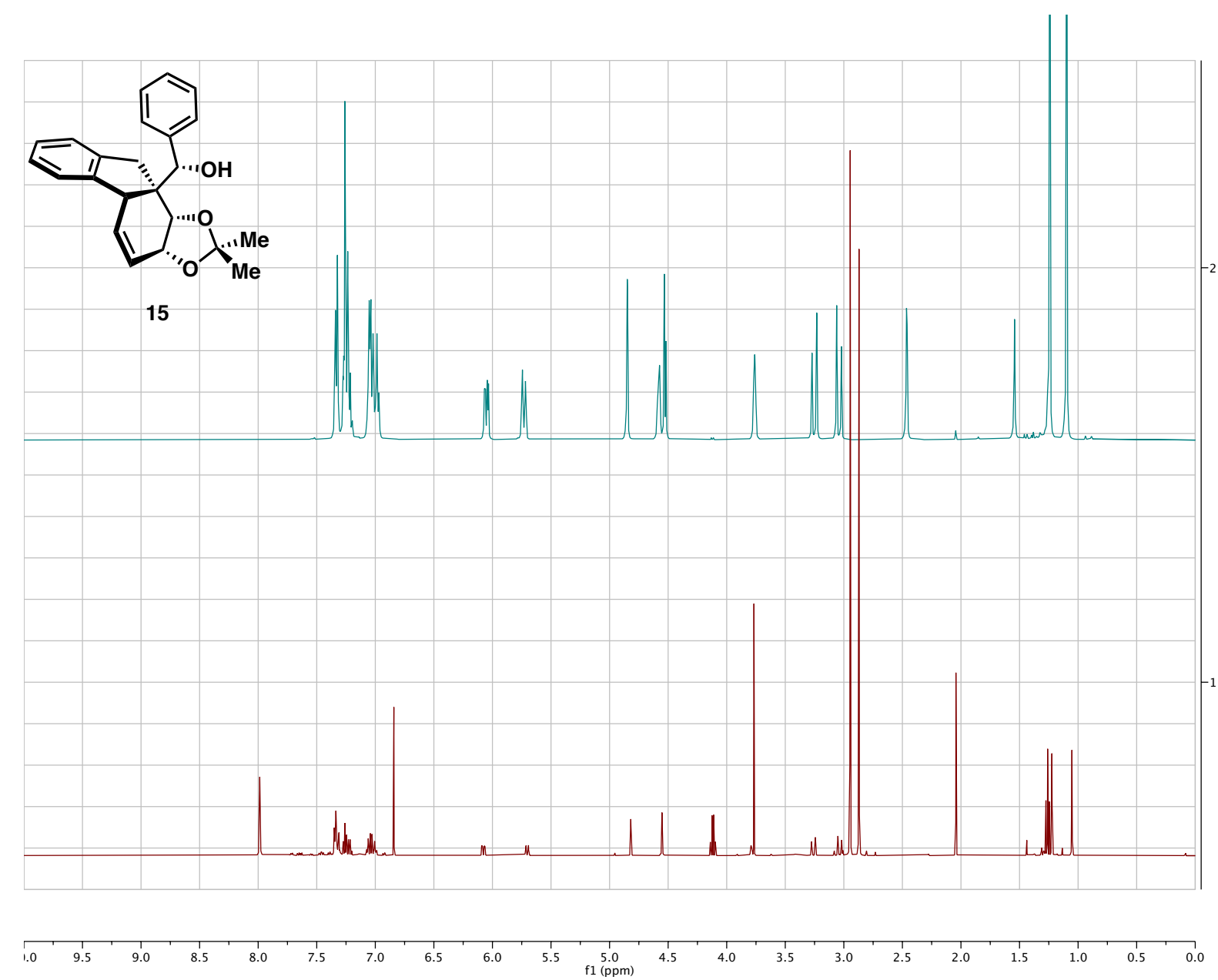




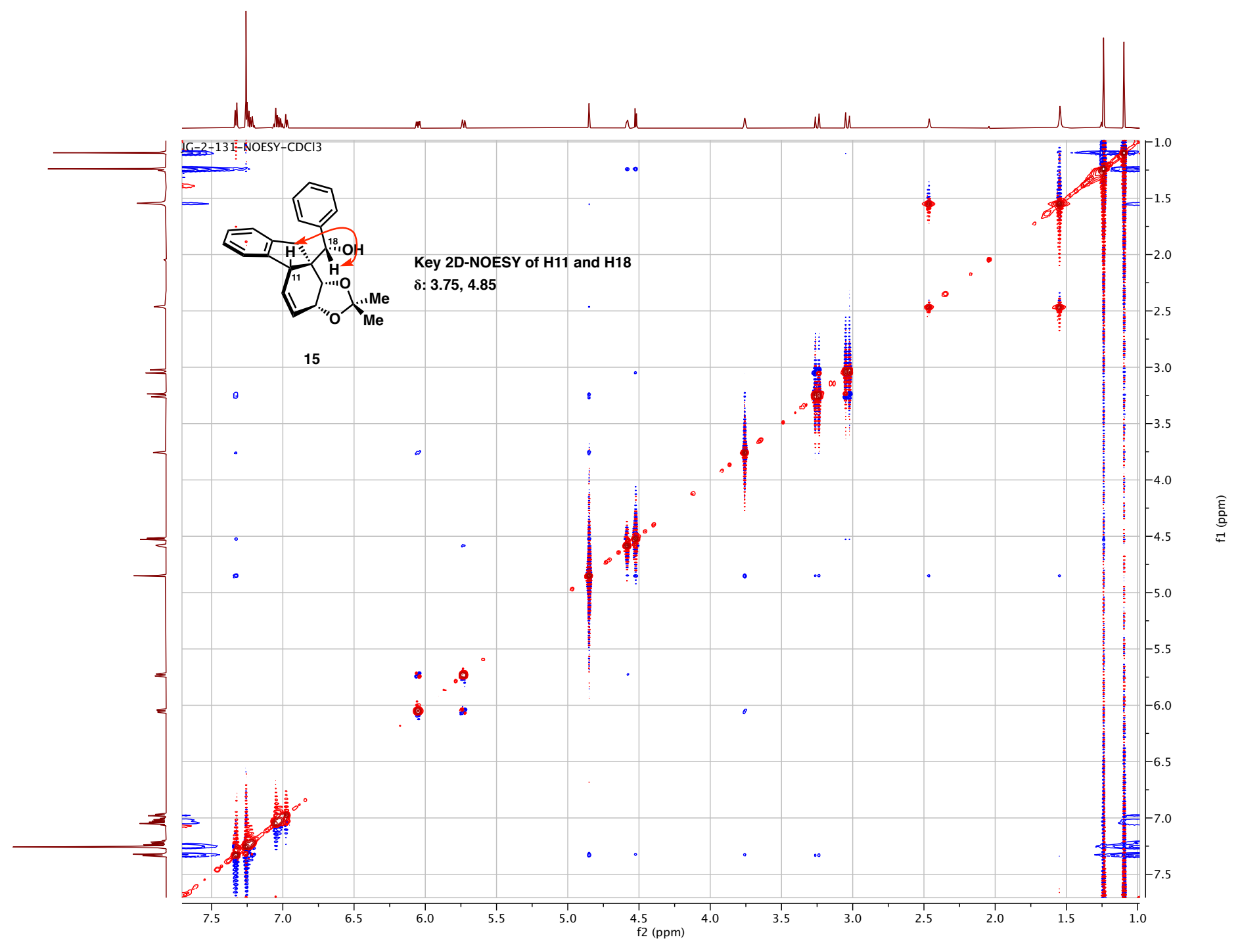




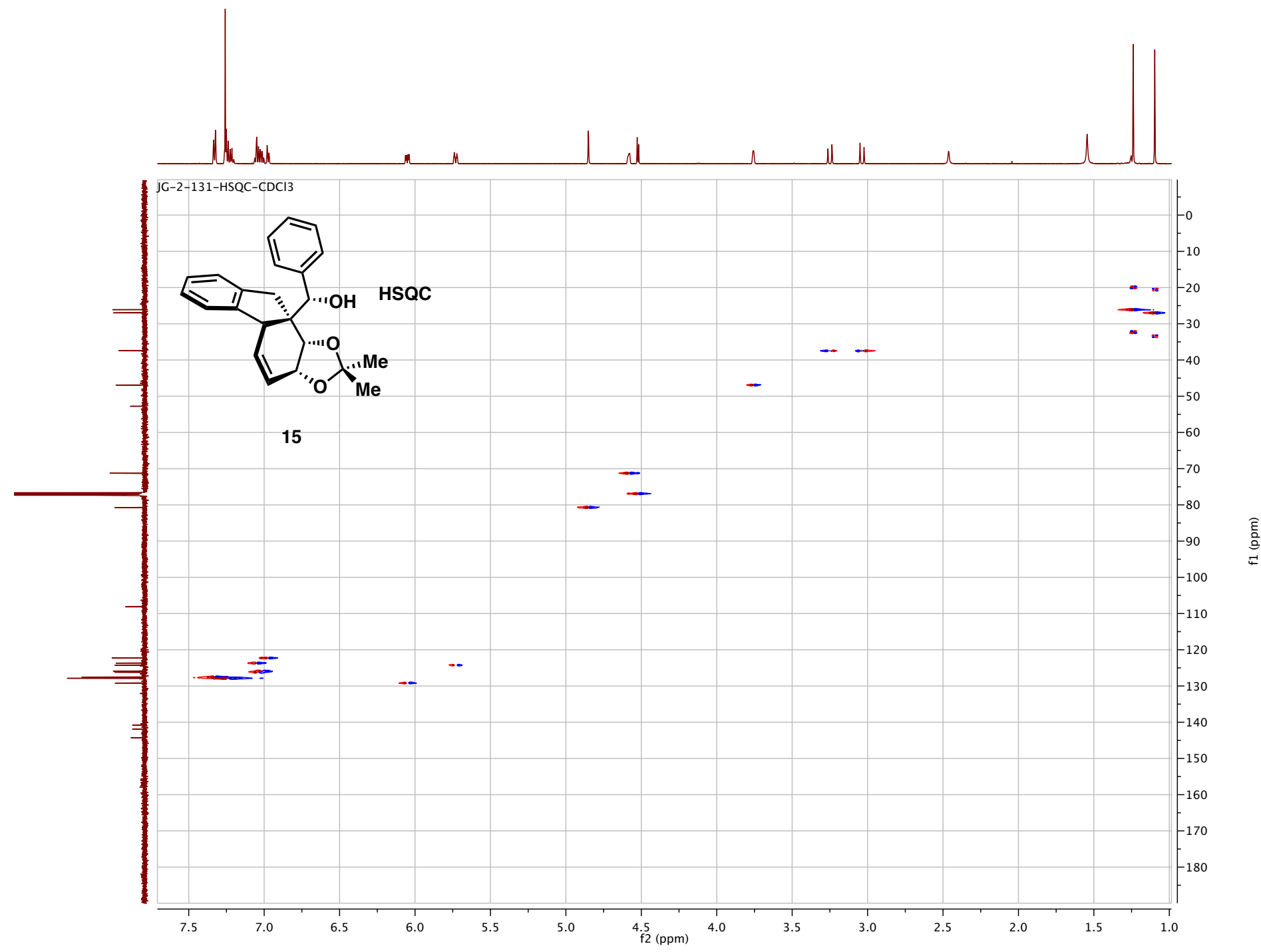




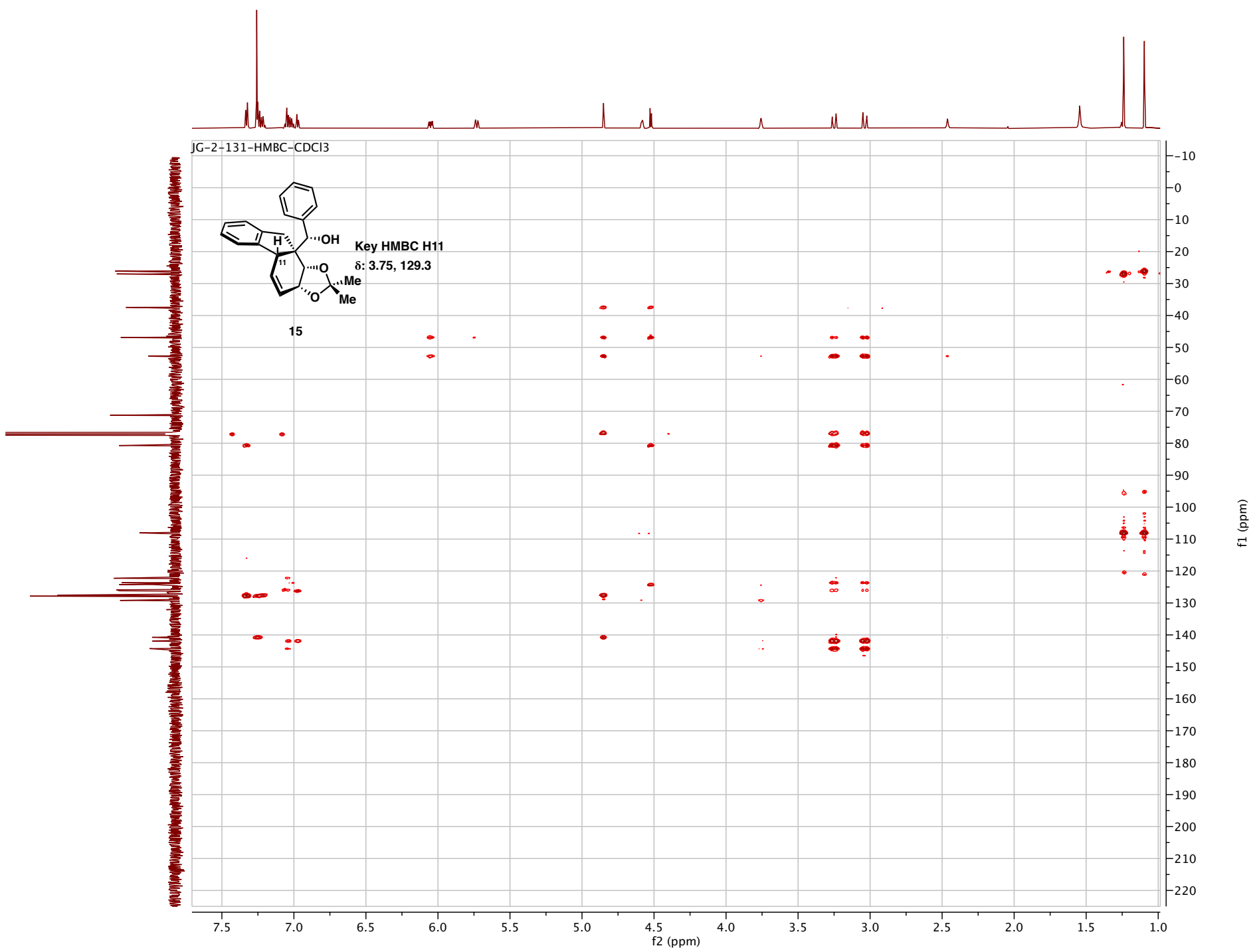

S75 


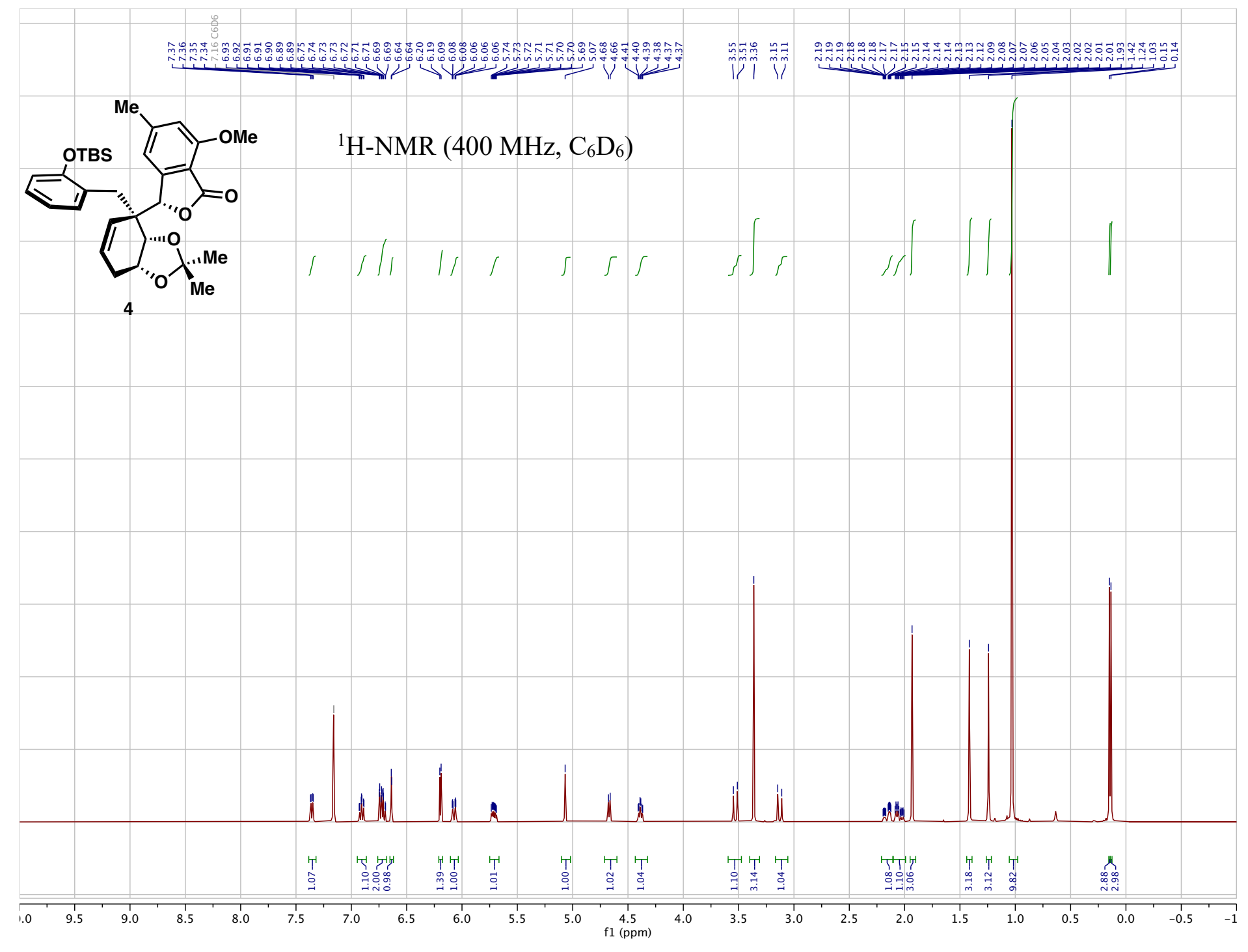




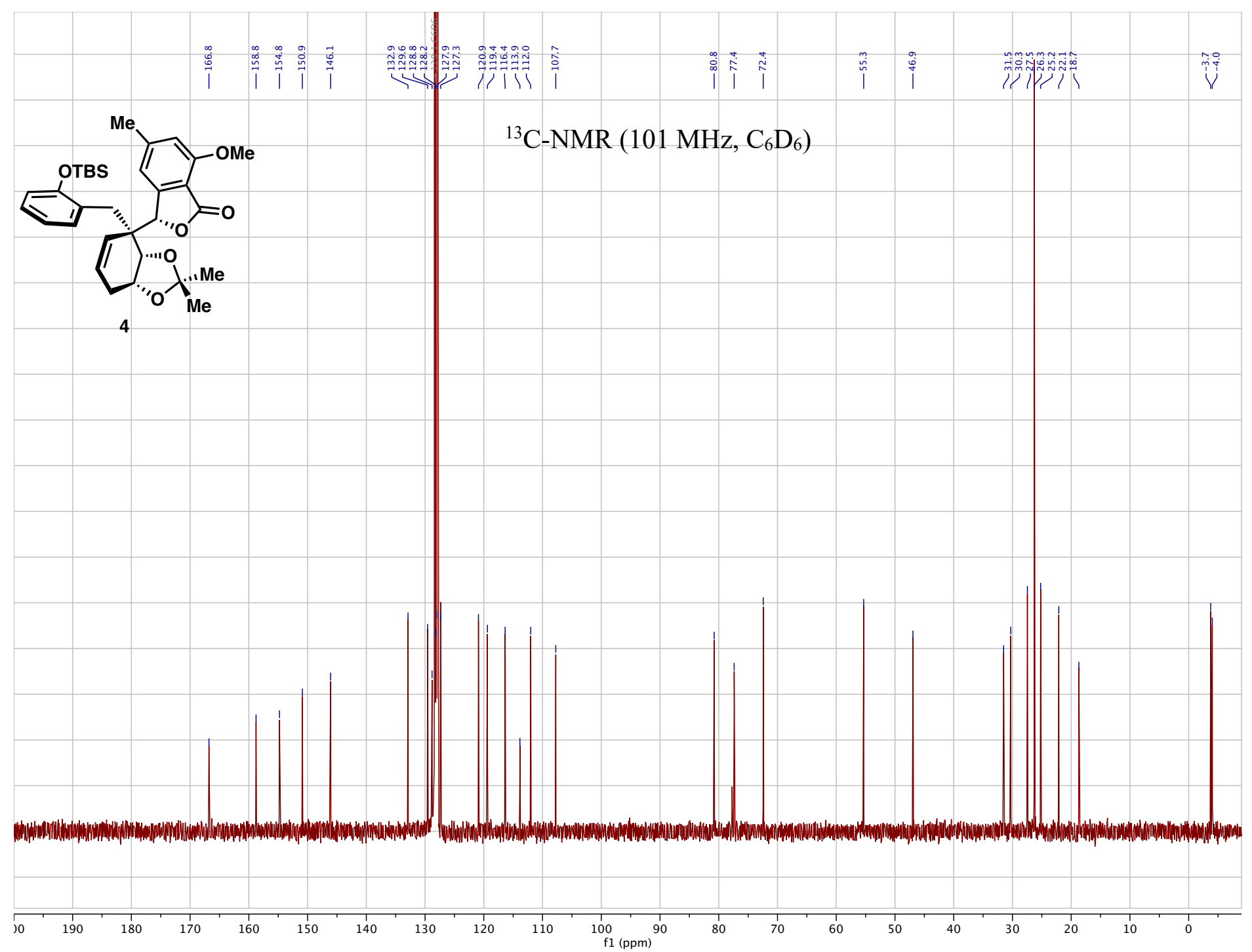




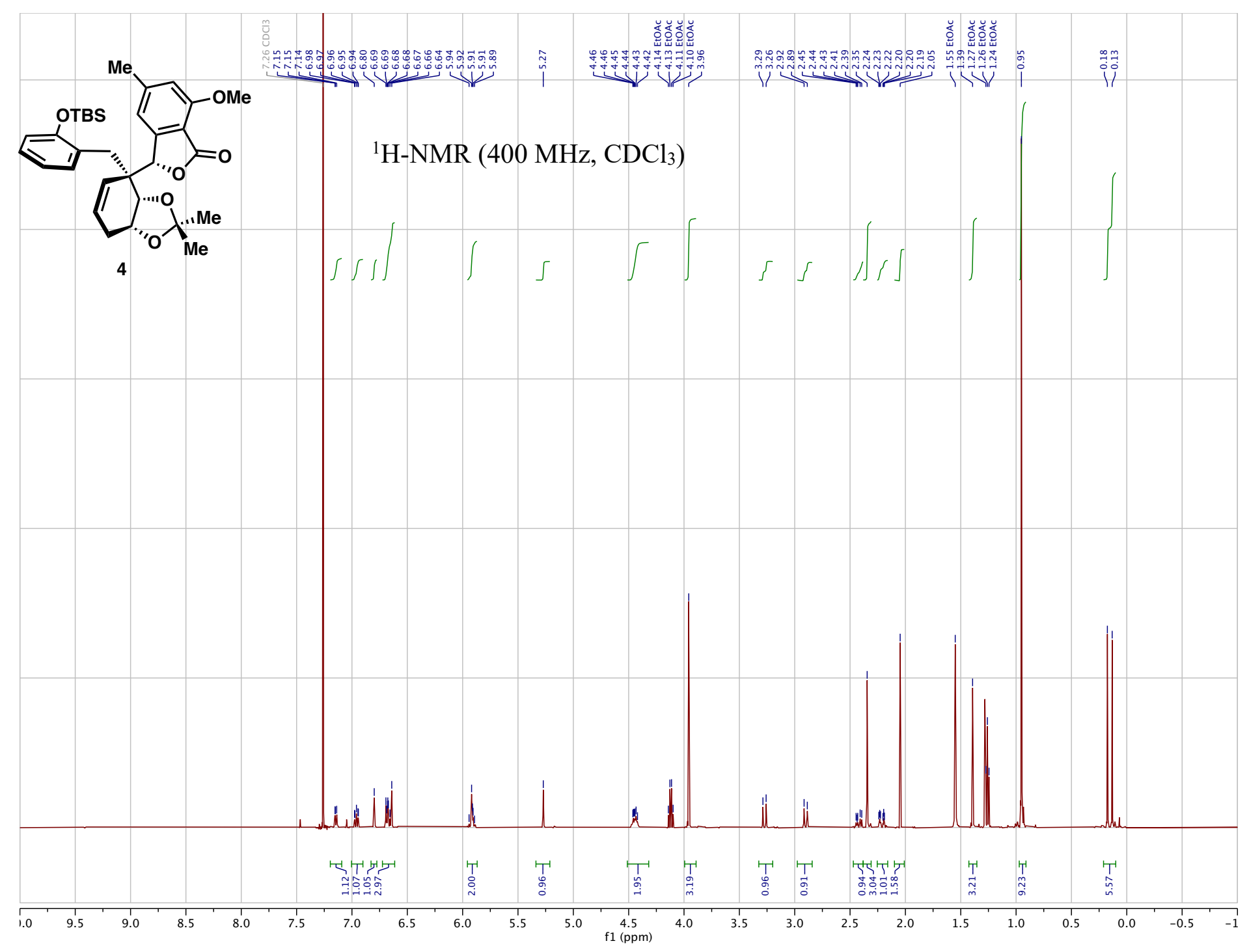


Borylation/Allylation ${ }^{1} \mathbf{H}$ NMR $\left(\mathbf{C D C l}_{3}\right)$ crude analysis: alcohol 11 (top); aldehyde 5 ( $2^{\text {nd }}$ from top); allylation product 4 ( $2^{\text {nd }}$ from bottom); crude extract (bottom).

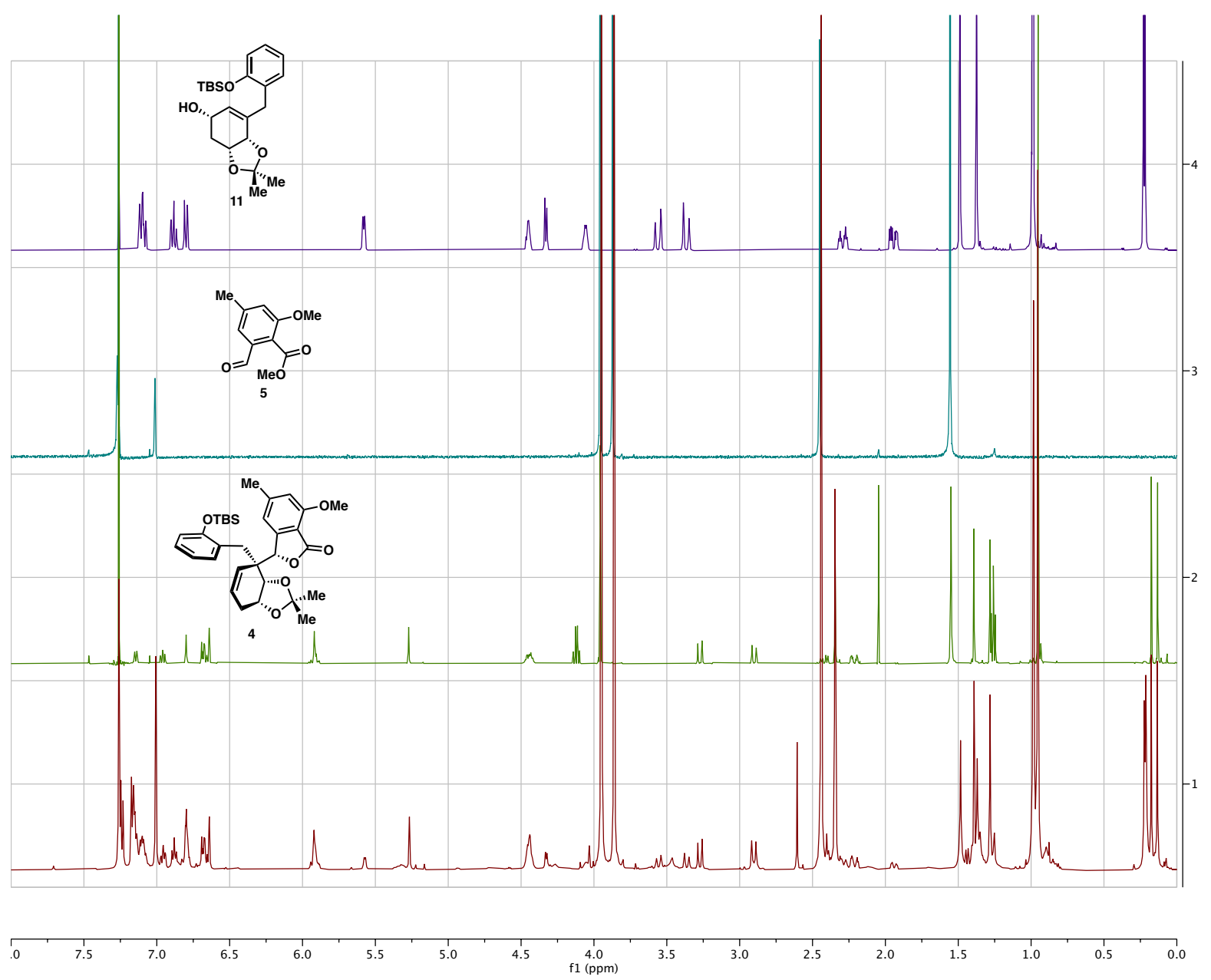




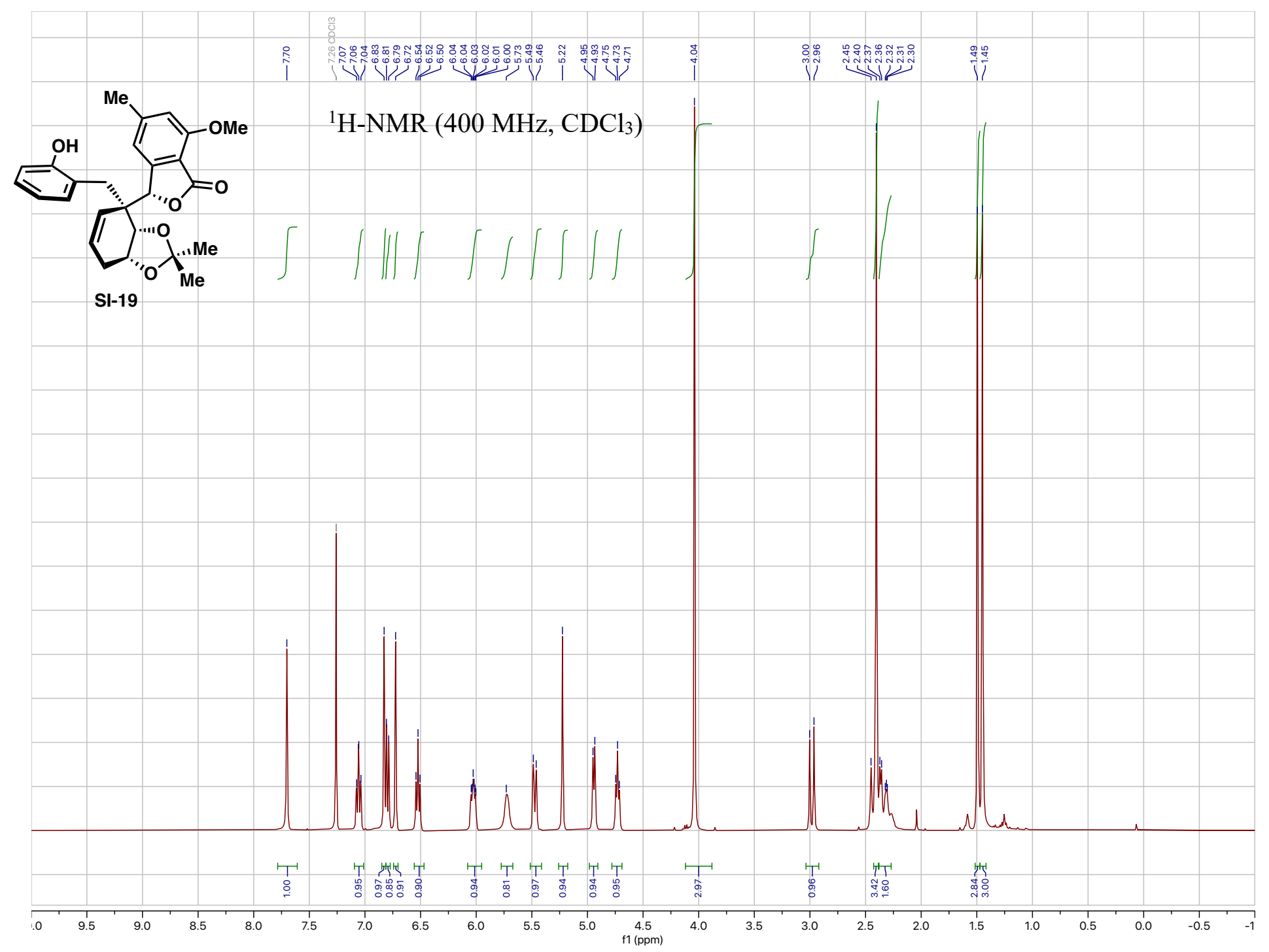



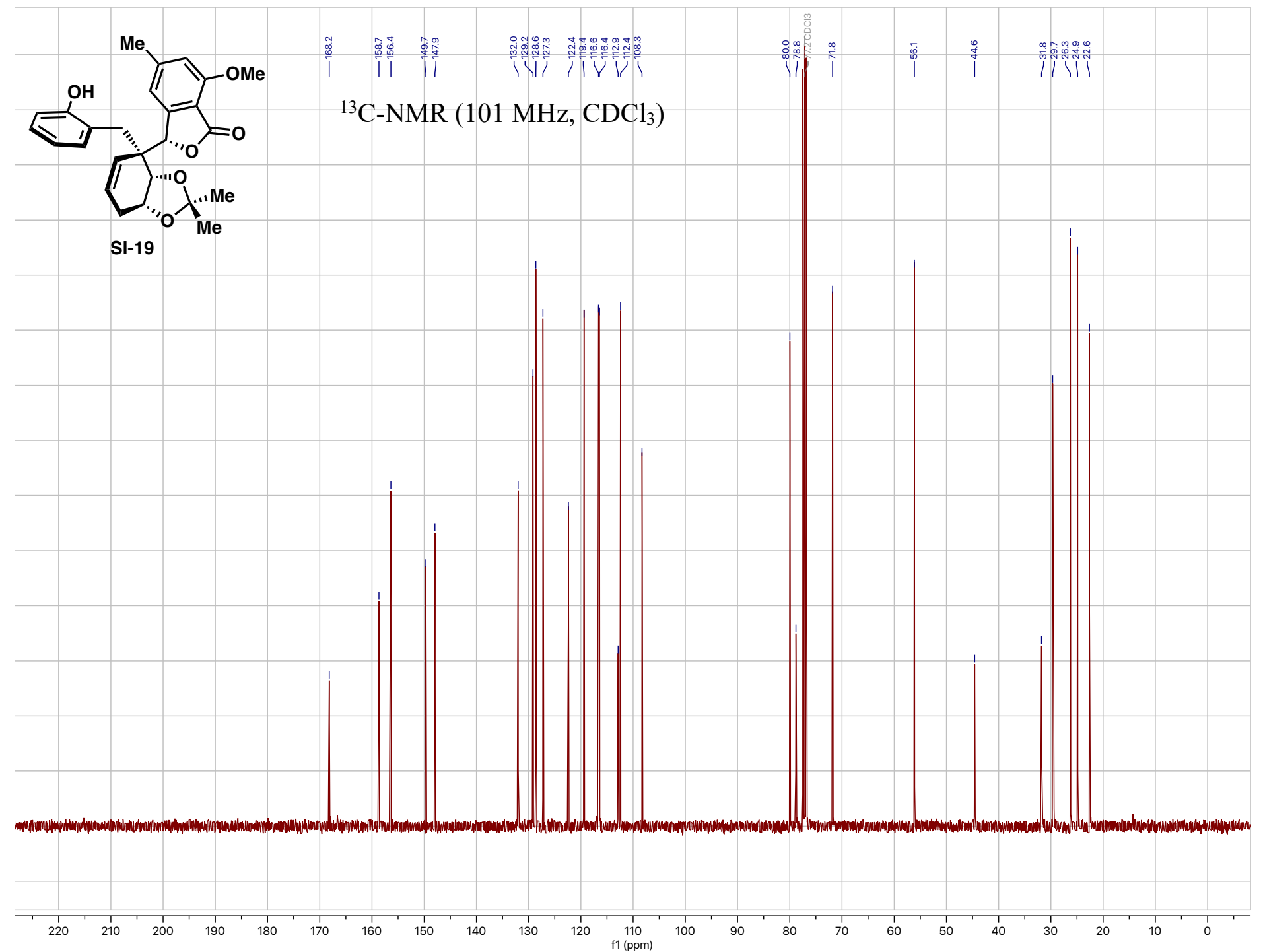


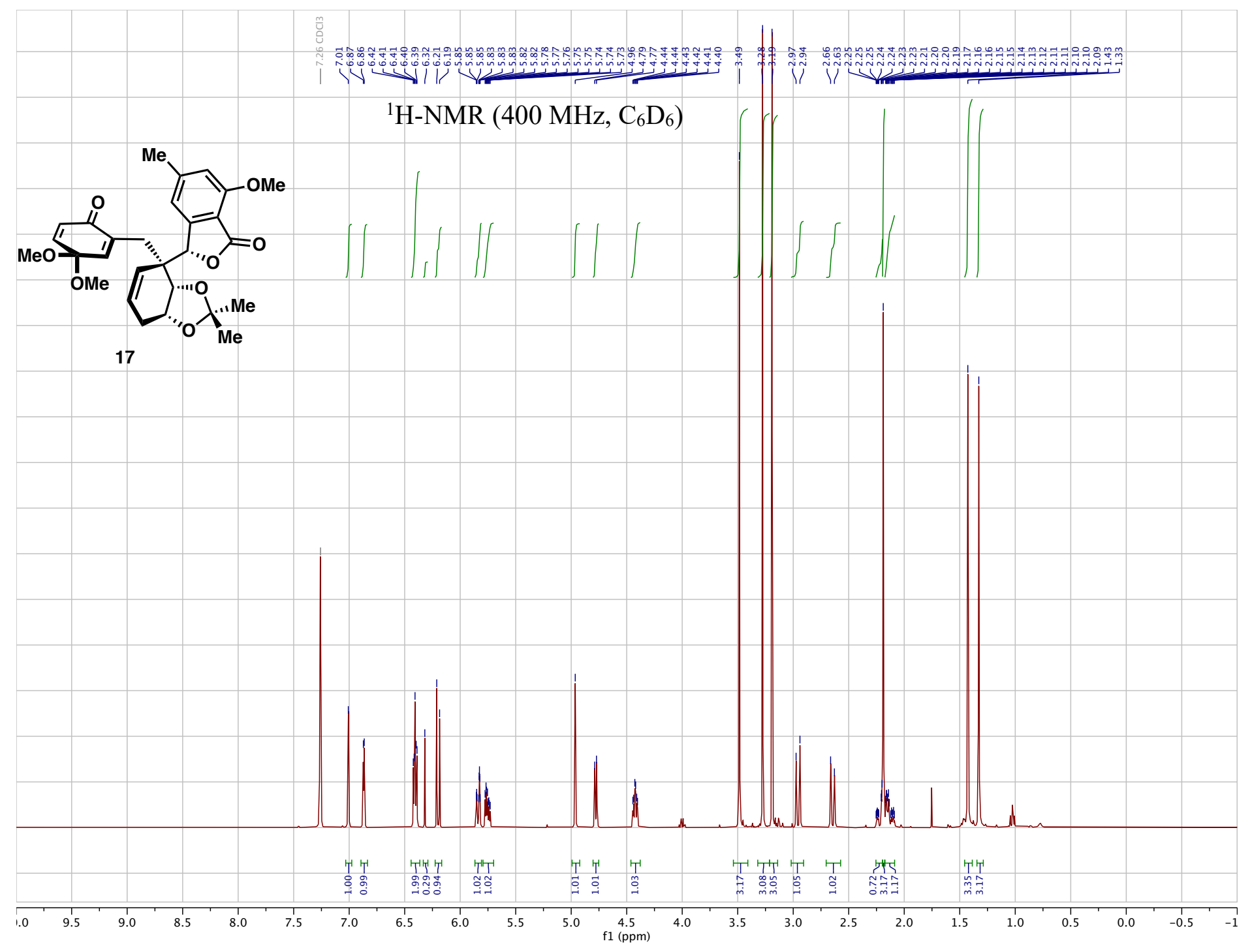




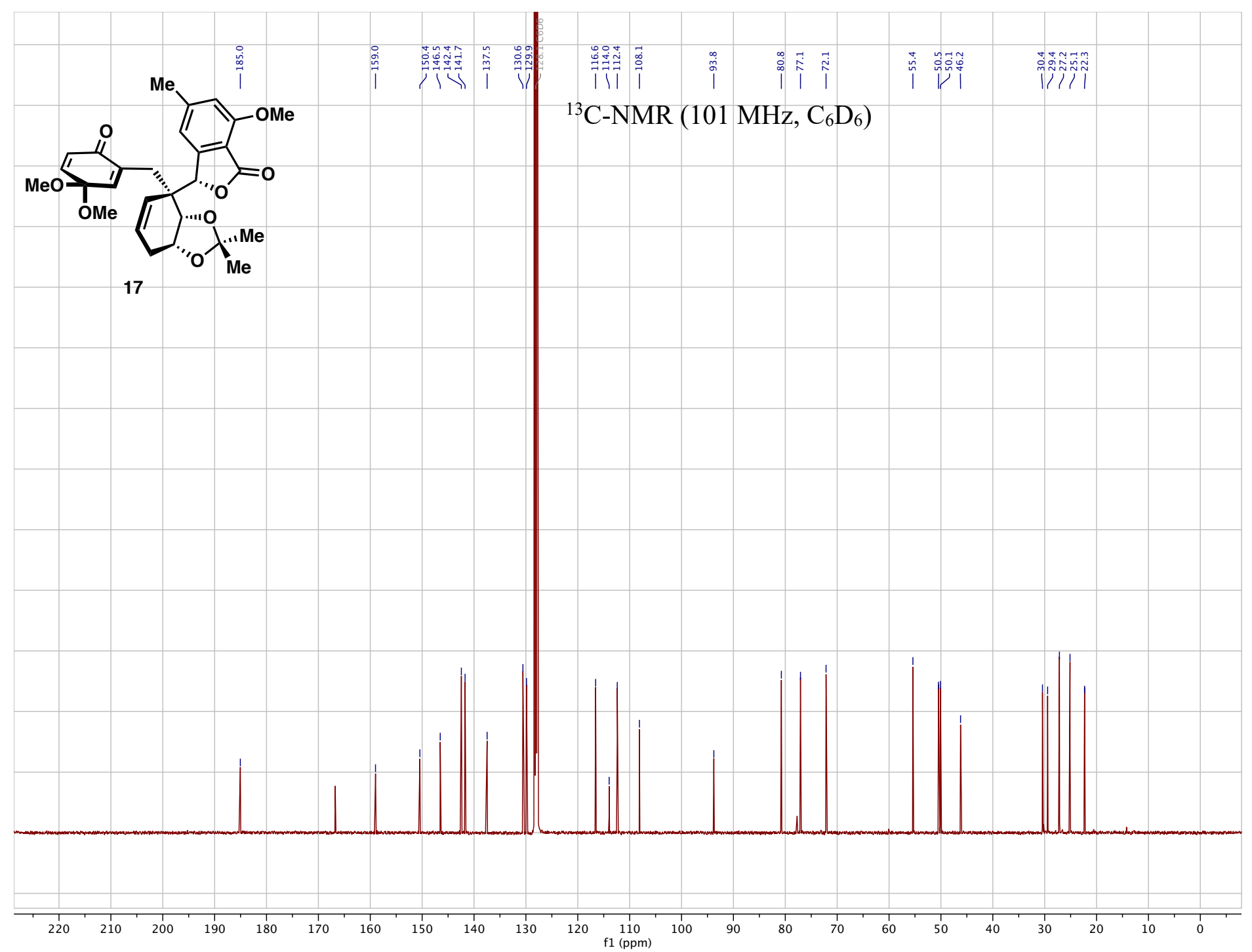




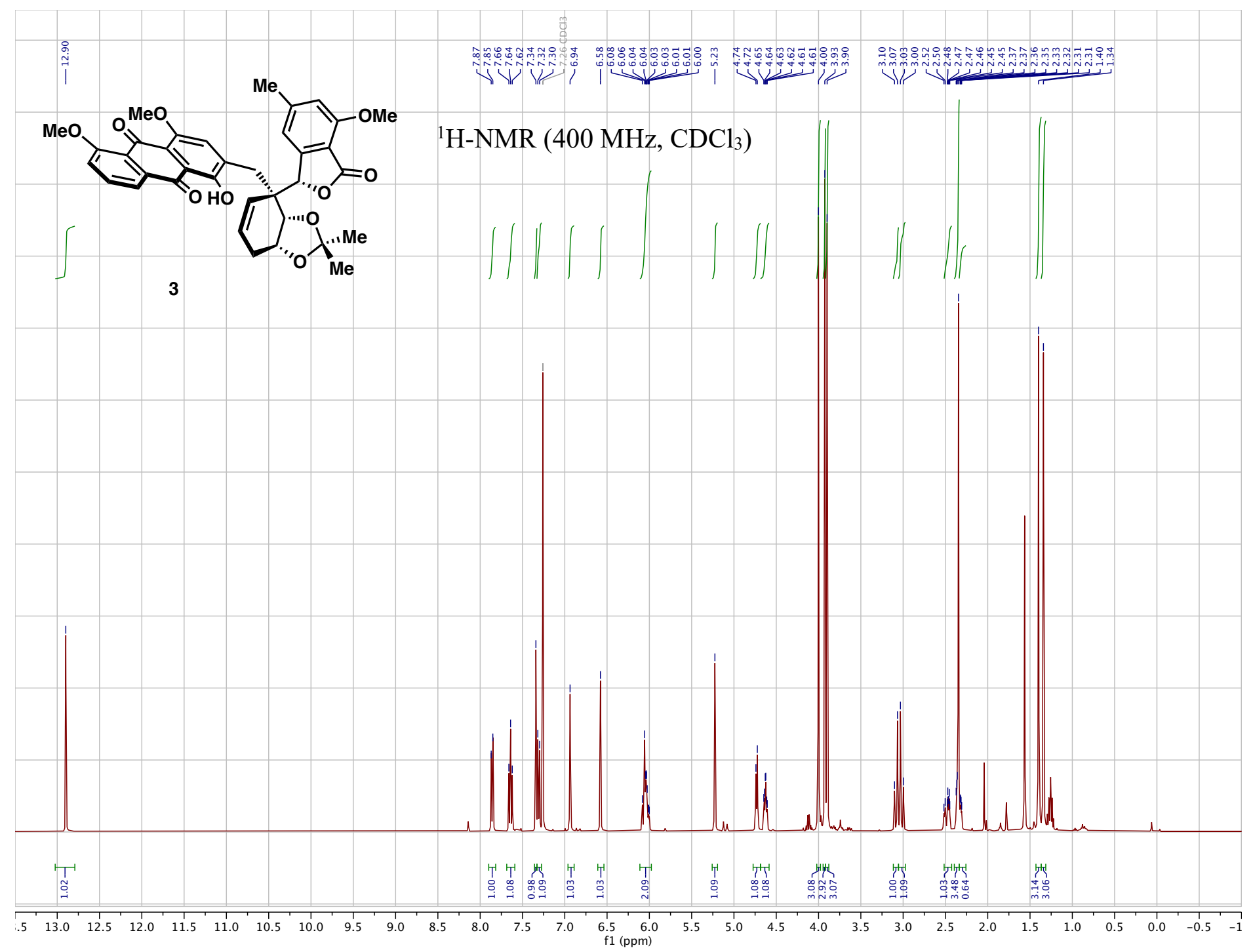




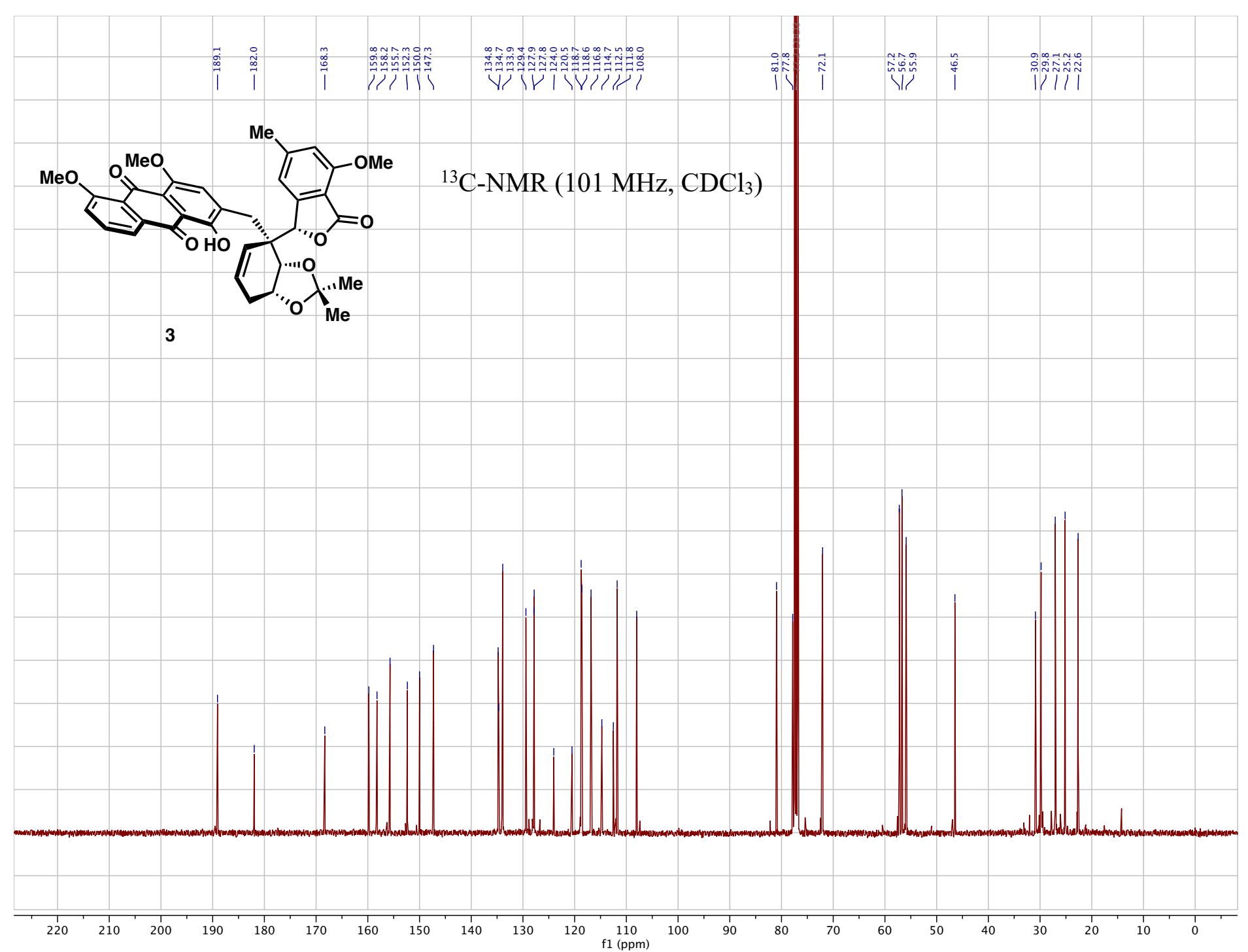




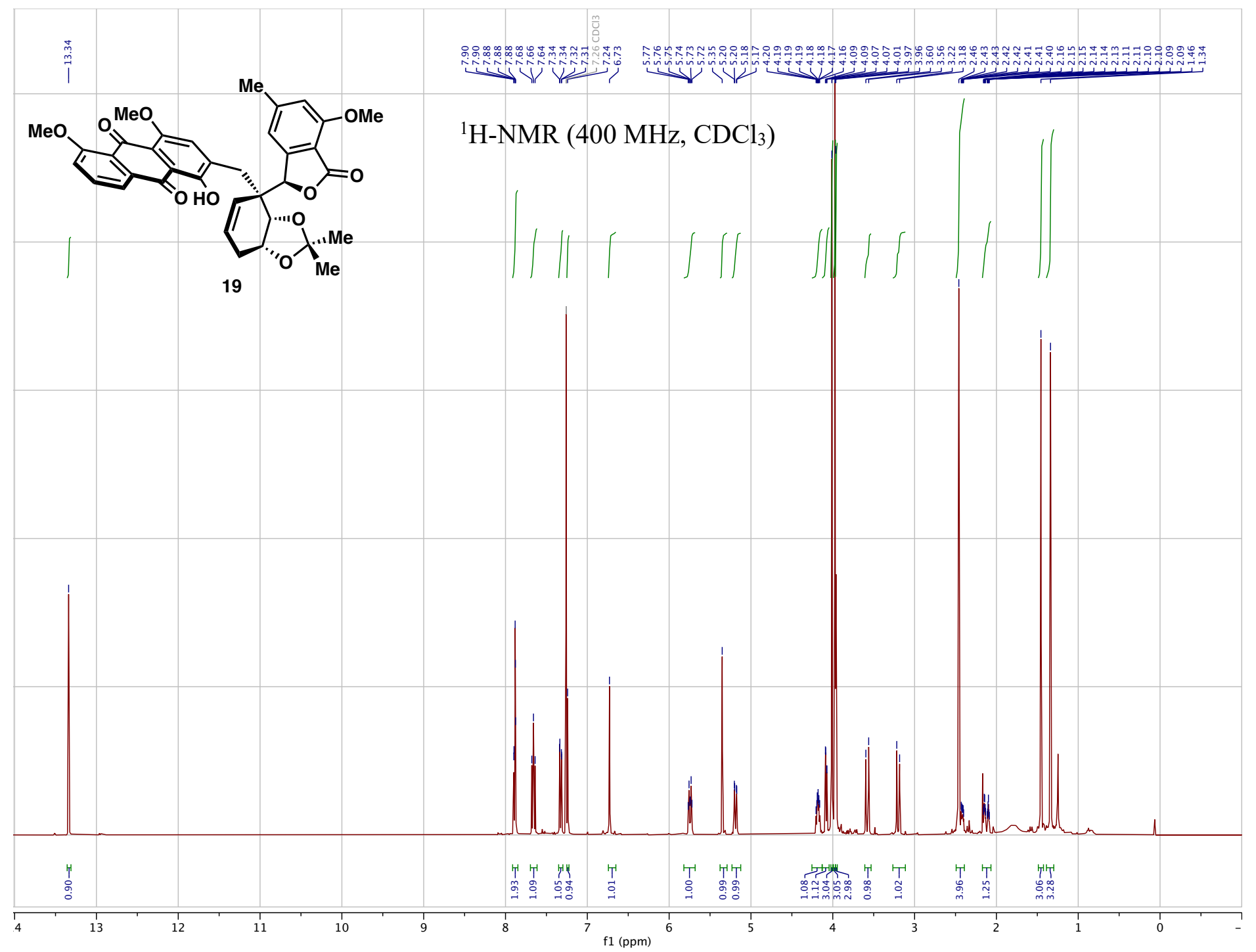




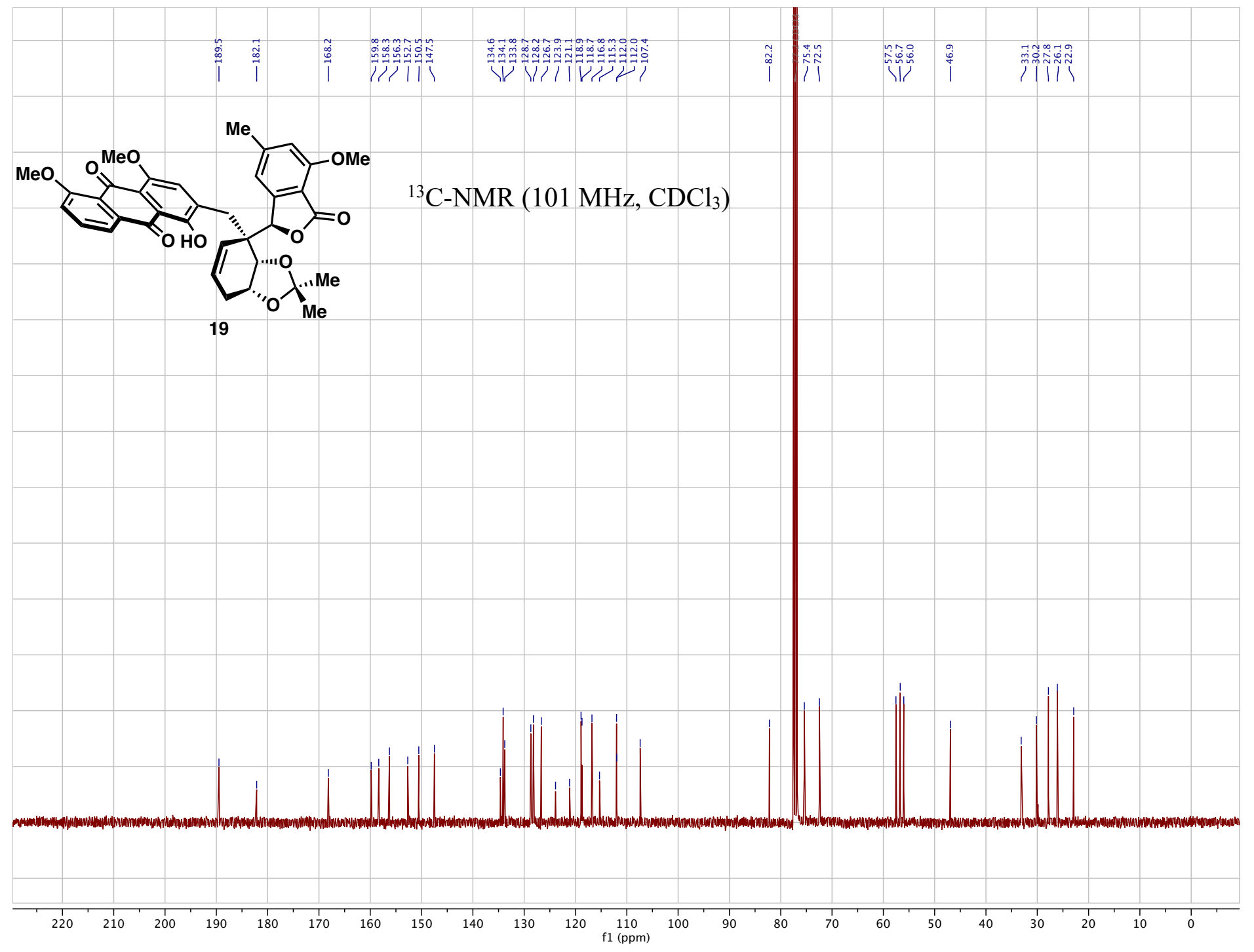

S87 


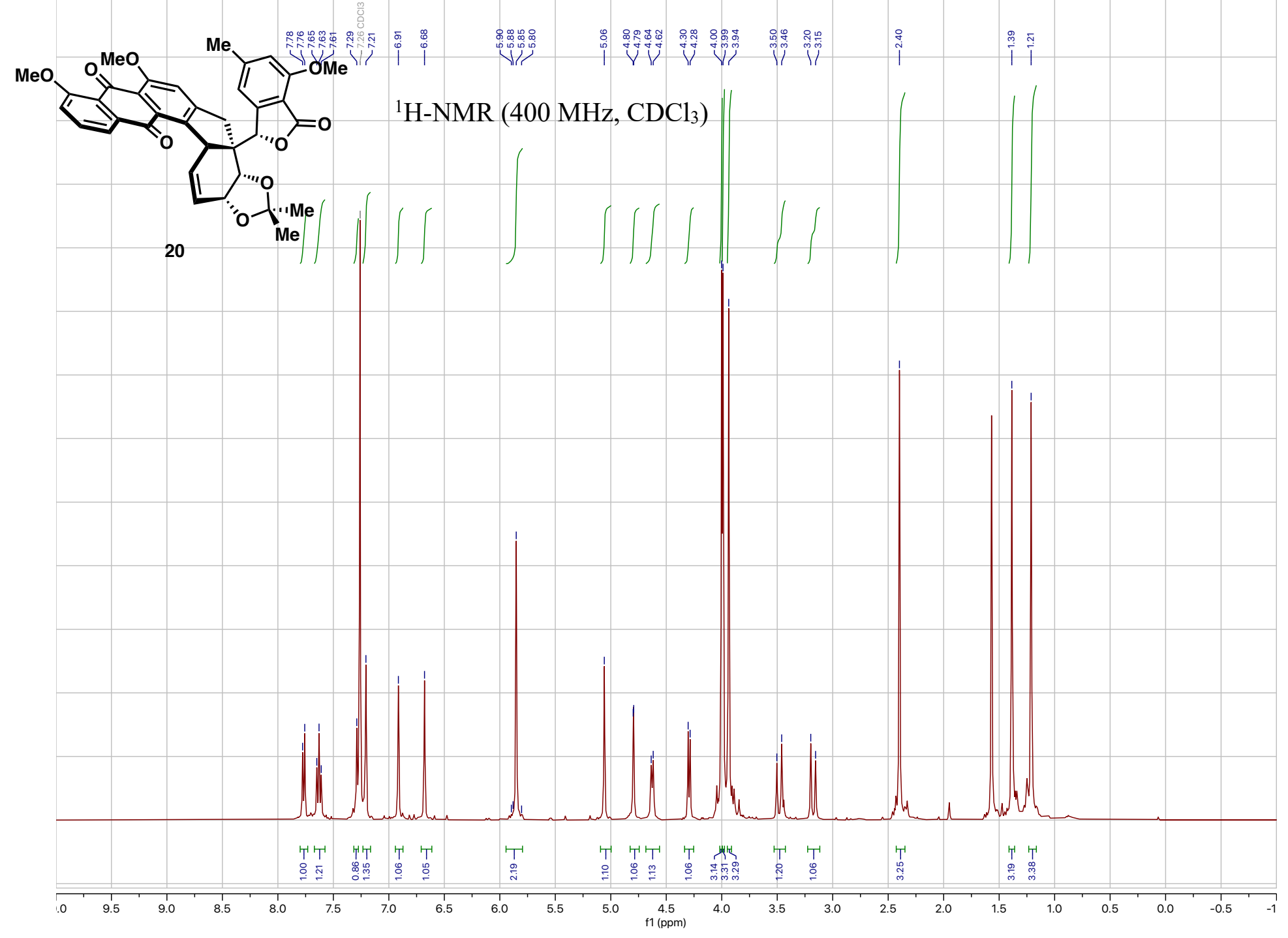




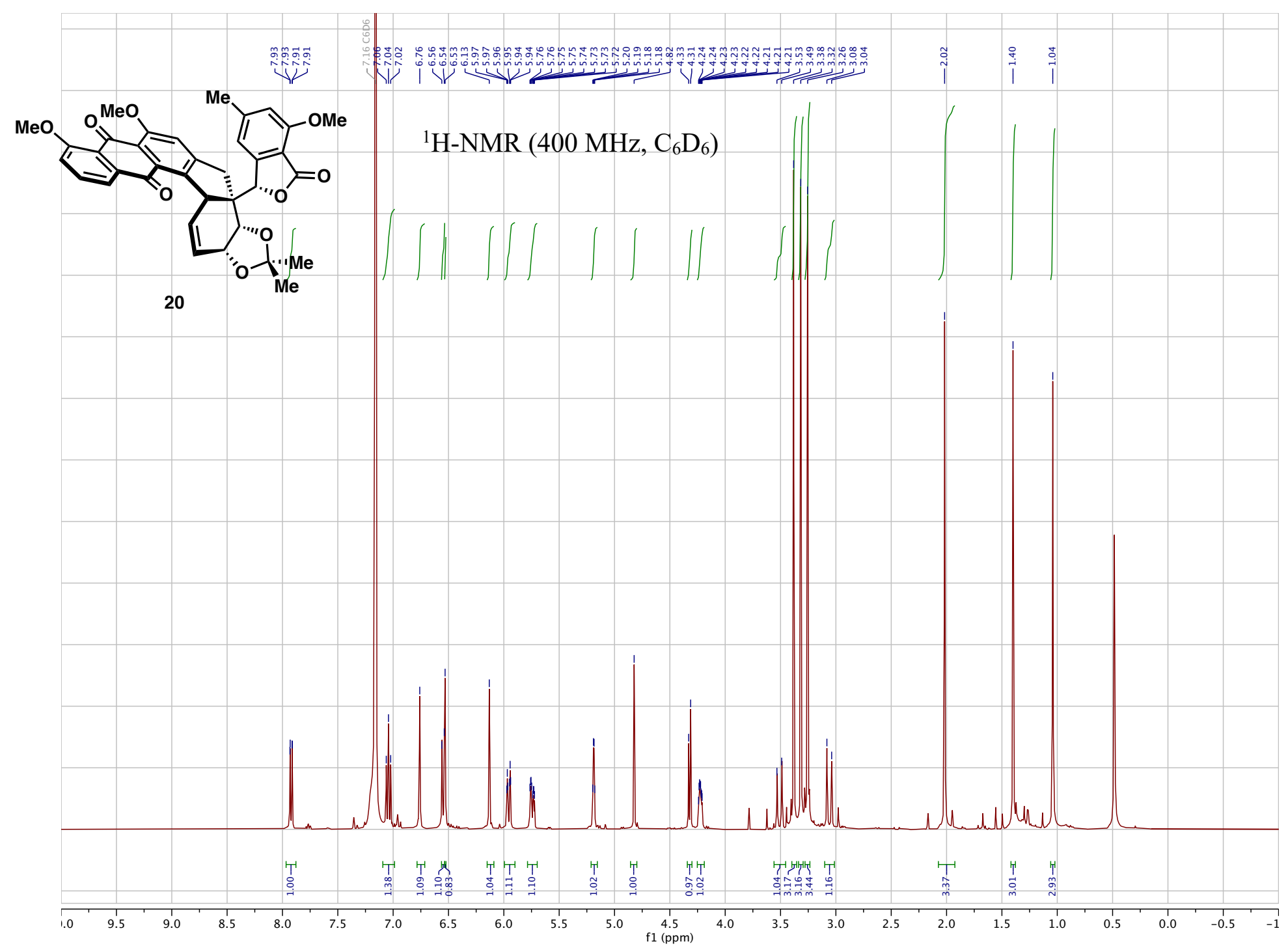




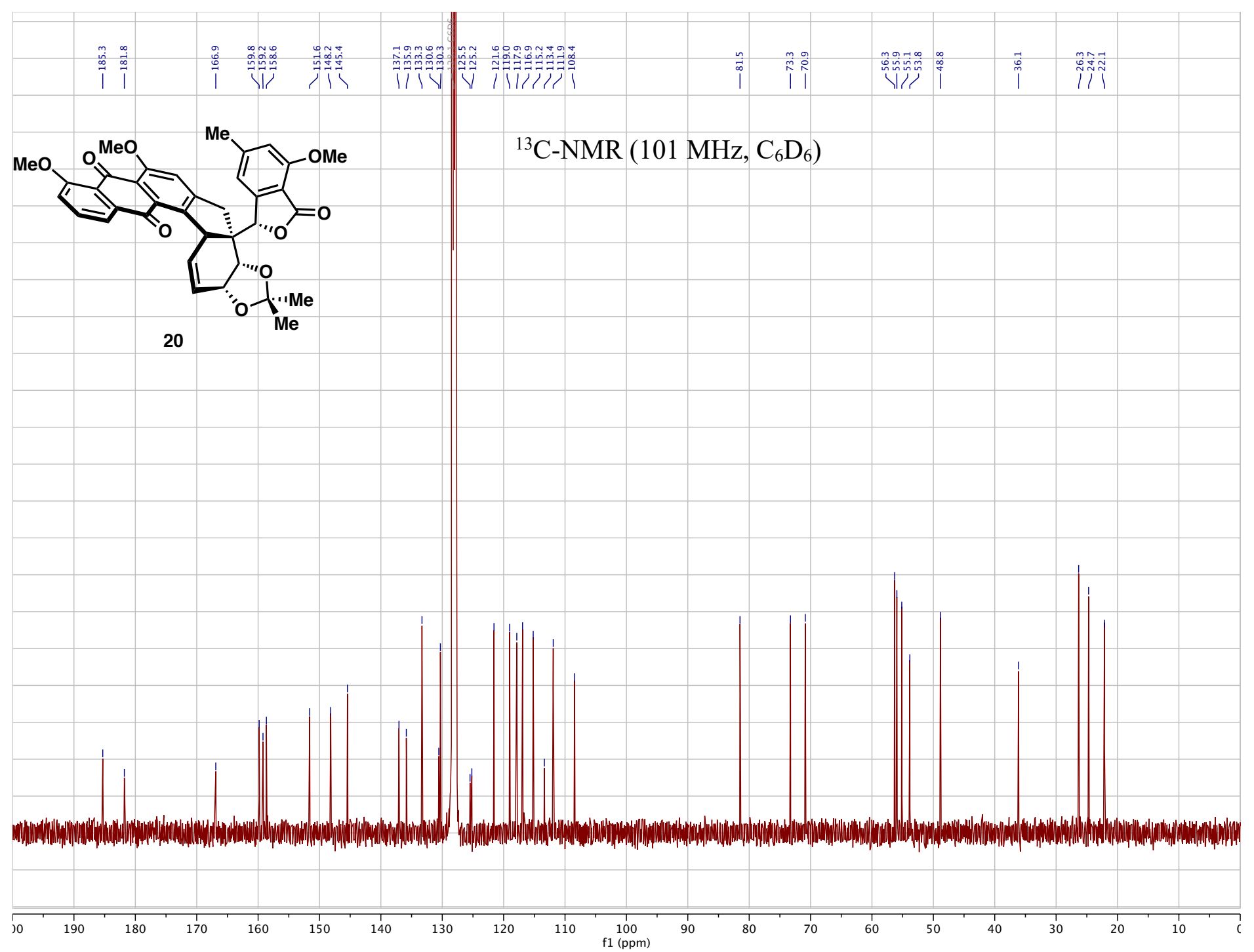


Triflation/Heck reaction sequence ${ }^{1} \mathbf{H}$ NMR $\left(\mathbf{C D C l}_{3}\right)$ crude analysis: Heck reaction product $\mathbf{2 0}$ (top), anthraquinone starting material 3 (middle), crude extract (bottom).
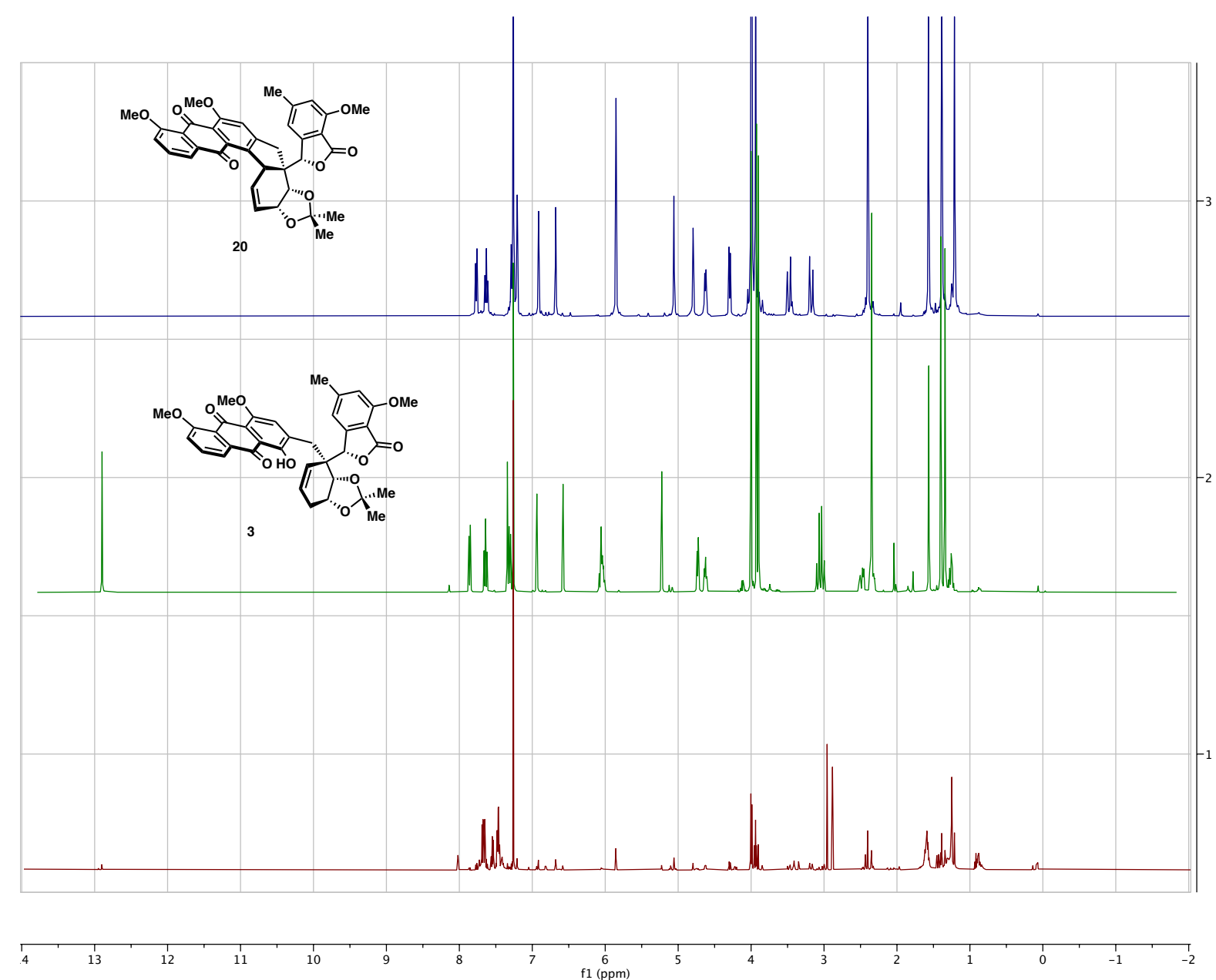


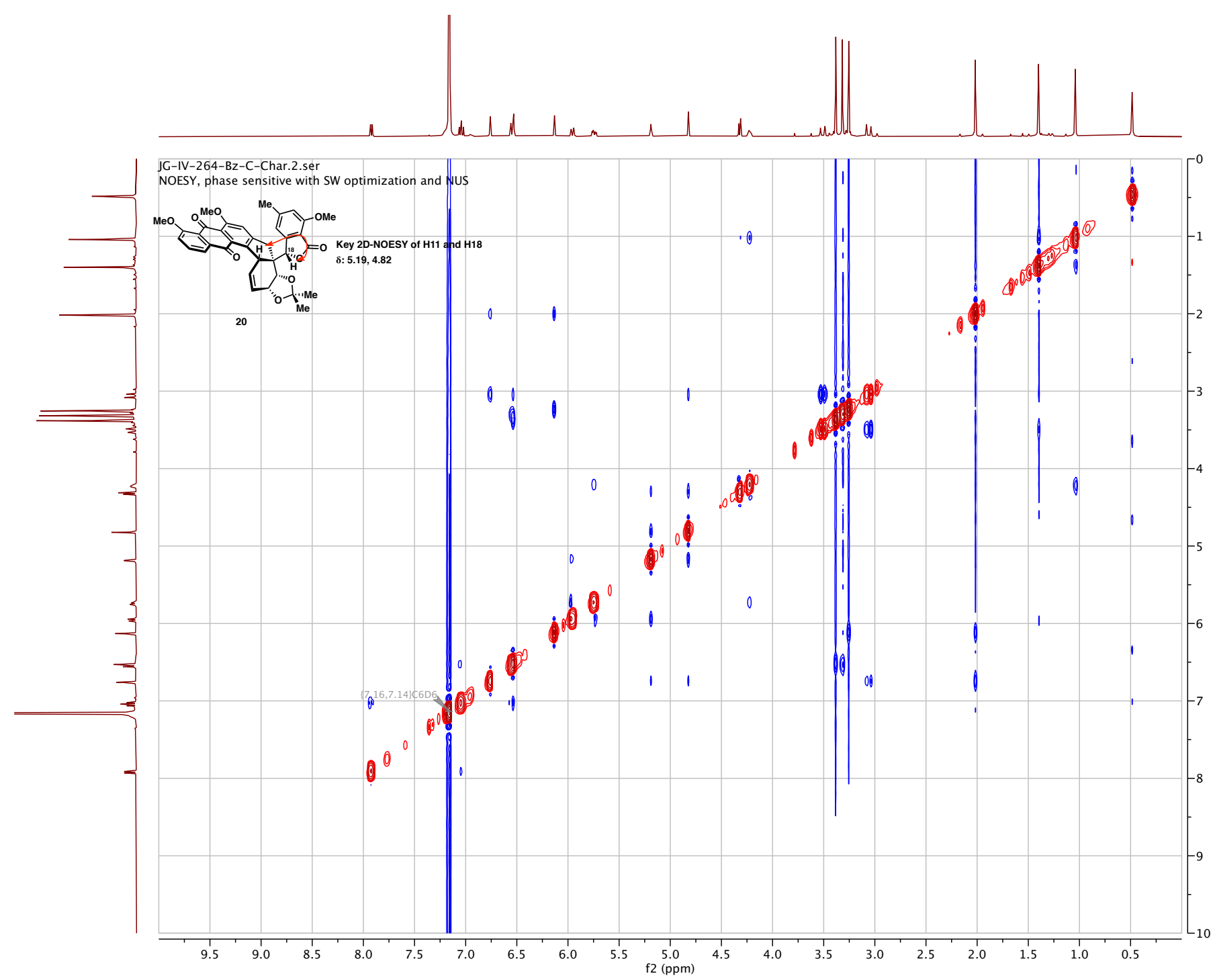




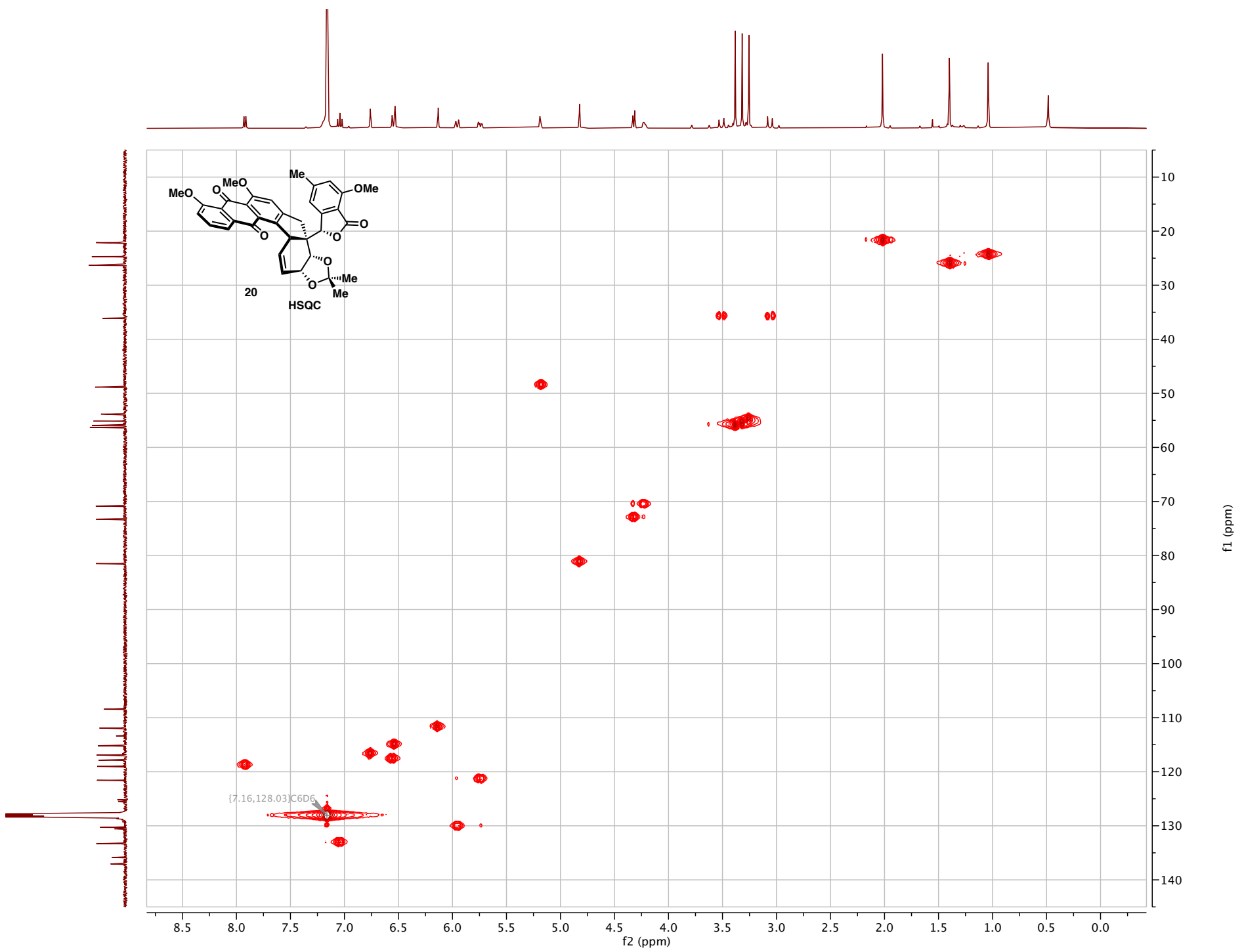

S93 


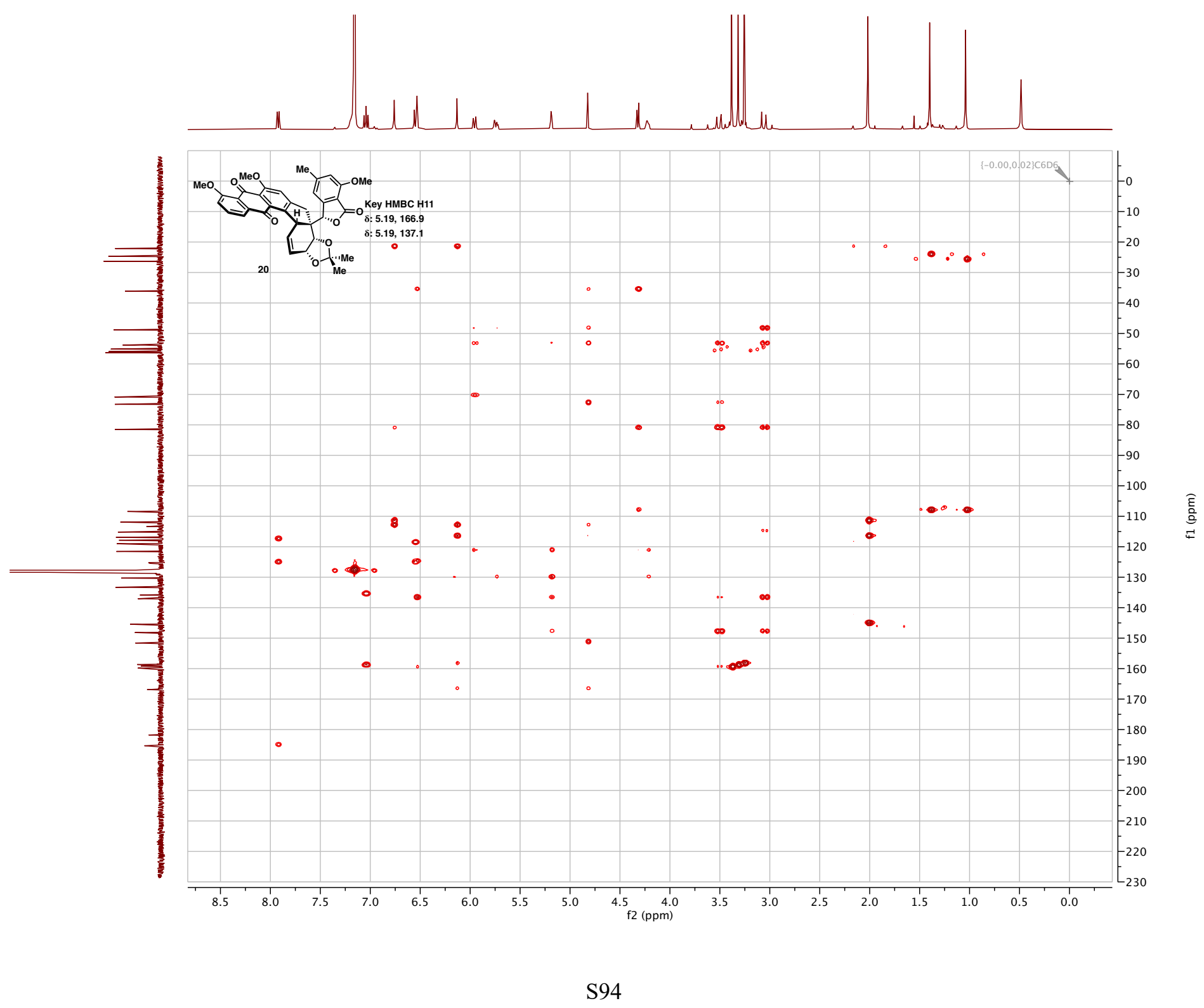




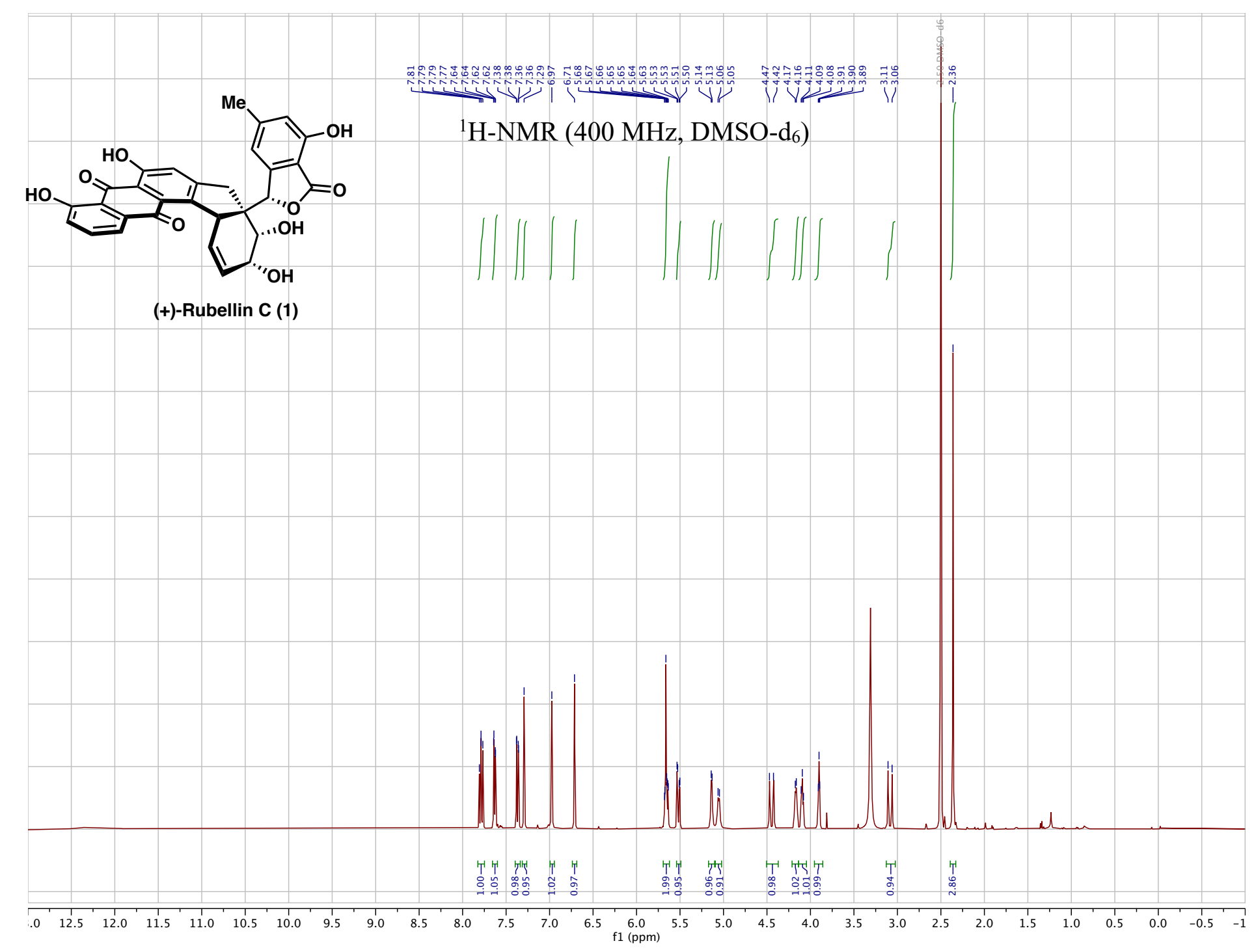




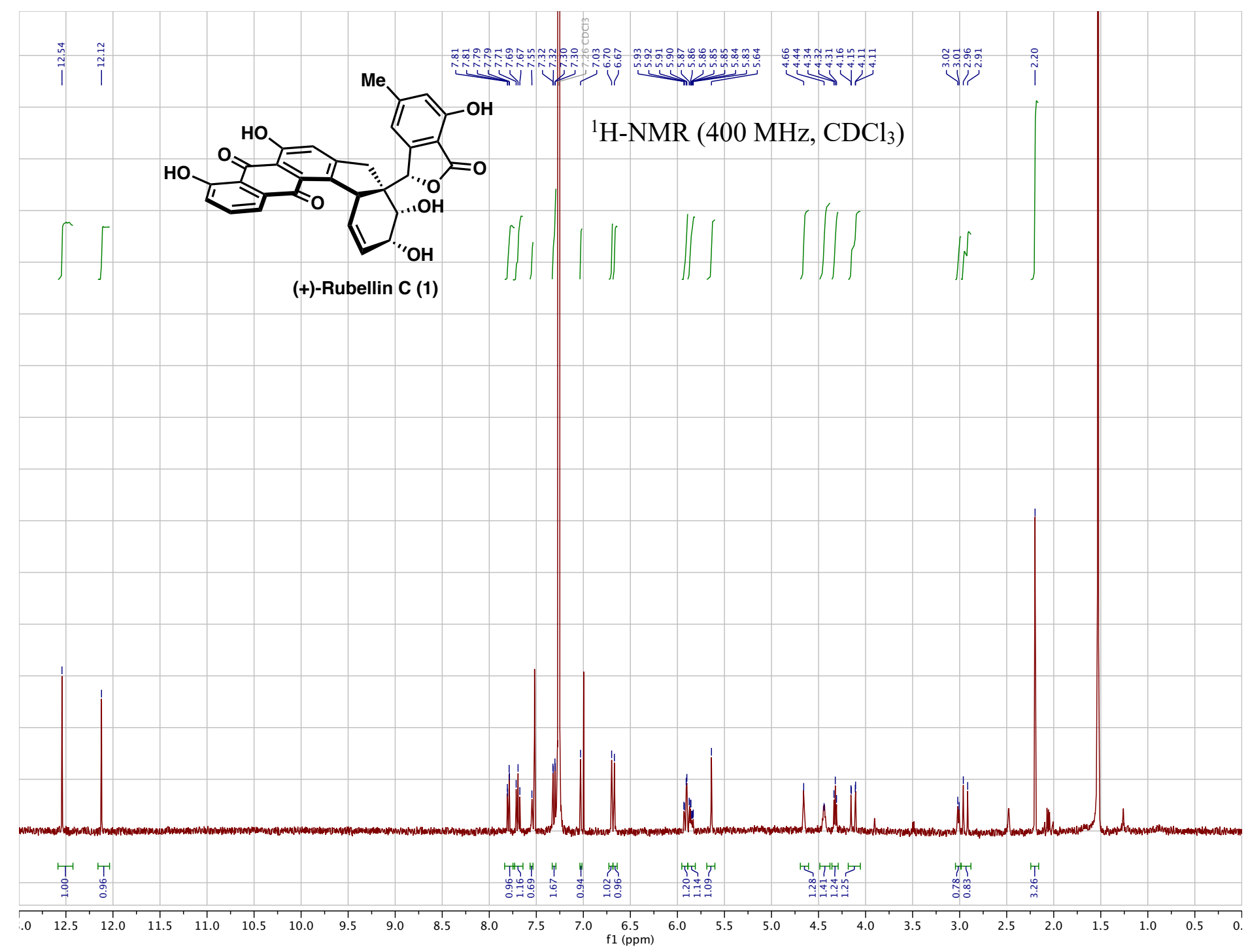




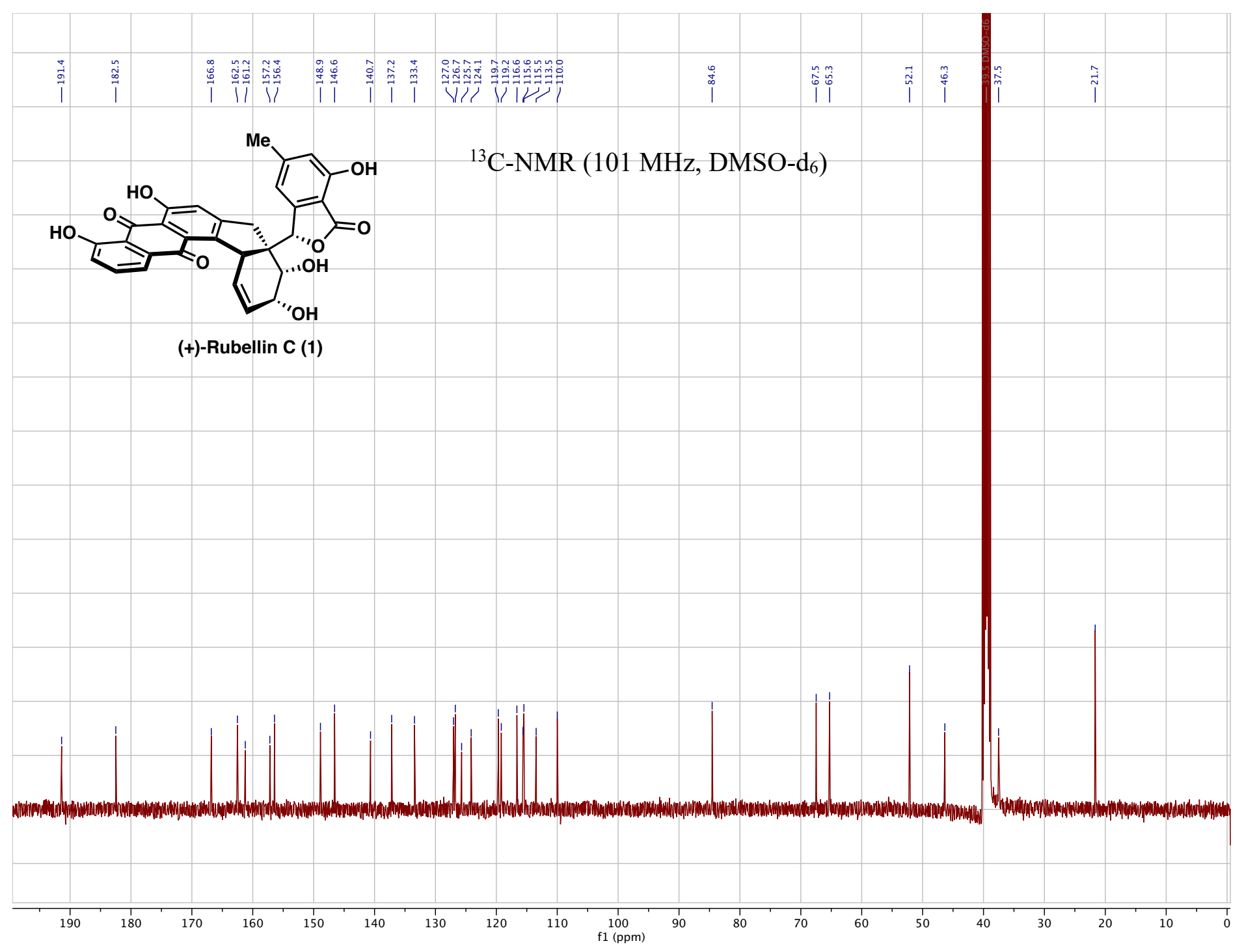




\section{References S1-S10}

S1. A. Arnone, G. Nasini, L. Camarda, G. Assante, Secondary Mould Metabolites. XXV. The Structure of Rubellins C and D, Two Novel Anthraquinone Metabolites from Mycosphaerella rubella. Gazz. Chim. Ital. 119, 35-39 (1989).

S2. M. Li, Y. Li, K. A. Ludwik, Z. M. Sandusky, D. A. Lannigan, A. G. O’Doherty, Stereoselective Synthesis and Evaluation of C6"Substituted 5a-Carbasugar Analogues of SL0101 as Inhibitors of RSK1/2. Org. Lett. 19, 2410-2413 (2017).Trost, B. M.; Romero, A. G., Synthesis of Optically Active Isoquinuclidines Utilizing a Diastereoselectivity Control Element. J. Org. Chem. 51, 2332-2342 (1986).

S3. Z. X. Wang, S. M. Miller, O. P. Anderson, Y. Shi, A Class of $\mathrm{C}_{2}$ and Pseudo $\mathrm{C}_{2}$ Symmetric Ketone Catalysts for Asymmetric Epoxidation. Conformation Effect on Catalysis. J. Org. Chem. 64, 6443-6458 (1999).

S4. J. E. Audia, L. Boisvert, A. D. Patten, A. Villalobos, S. J. Danishefsky, Synthesis of Two Useful, Enantiomerically Pure Derivatives of (S)-4-Hydroxy-2-cyclohexenone. J. Org. Chem. 54, 3738-3740 (1989).

S5. J. Izquierdo, A. Orue, K. A. Scheidt, A Dual Lewis Base Activation Strategy for Enantioselective Carbene-Catalyzed Annulations. J. Am. Chem. Soc. 135, 10634-10637 (2013).

S6. S. K. Mamidyala, M. A. Cooper, Probing the reactivity of $o$-phthalaldehydic acid/methyl ester: synthesis of $N$-isoindolinones and 3-arylaminophthalides. Chem. Comm. 49, 8407-8409 (2013).

S7. M. A. Brimble, V. Caprio, A. D. Johnston, M. Sidford, Synthesis of Arylspiroketals Related to the Papulacandins via Generation of Phthalide Oxycarbenium Ions. Synthesis 6, 855-862 (2001).

S8. M. A. Bates, P. G. Sammes, G. A. Thomson, Synthesis of the $C$-Glycoside Fragment of Nogalamycin and some Nogalamycin Precursors. J. Chem. Soc. Perkin Trans. I 3037-3045 (1988).

S9. D. Wang, K. J. Szabó, Copper-Catalyzed, Stereoselective Cross-Coupling of Cyclic Allyl Boronic Acids with $\alpha$-Diazoketones.

Org. Lett. 19, 1622-1625 (2017). 
S10. S. Miethbauer, S. Haase, K.-U. Schmidtke, W. Günther, I. Heiser, B. Liebermann, Biosynthesis of photodynamically active rubellins and structure elucidation of the new anthraquinone derivatives produced by Ramularia collo-cygni. Phytochemistry $\mathbf{6 7}$, 1206-1213 (2006). 